\title{
As interfaces do direito agrário e dos direitos humanos e a segurança alimentar
}

\author{
Elisabete Maniglia
}

MANIGLIA, E. As interfaces do direito agrário e dos direitos humanos e a segurança alimentar [online]. São Paulo: Editora UNESP; São Paulo: Cultura Acadêmica, 2009. 277 p. ISBN 978-857983-014-3. Available from SciELO Books <http://books.scielo.org>.

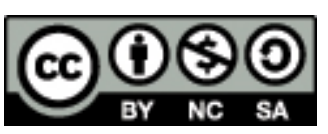

All the contents of this chapter, except where otherwise noted, is licensed under a Creative Commons Attribution-Non Commercial-ShareAlike 3.0 Unported.

Todo o conteúdo deste capítulo, exceto quando houver ressalva, é publicado sob a licença Creative Commons Atribuição Uso Não Comercial - Partilha nos Mesmos Termos 3.0 Não adaptada.

Todo el contenido de este capítulo, excepto donde se indique lo contrario, está bajo licencia de la licencia Creative Commons Reconocimento-NoComercial-CompartirIgual 3.0 Unported. 
AS INTERFACES

DO DIREITO AGRÁRIO

E DOS DIREITOS

HUMANOS

E A SEGURANÇA

ALIMENTAR

ELISABETE MANIGLIA 


\section{As INTERFACES DO DIREITO AGRÁRIO E DOS DIREITOS HUMANOS E A SEGURANÇA ALIMENTAR}





\section{ELISABETE MANIGLIA}

\section{As INTERFACES DO DIREITO AGRÁRIO E DOS DIREITOS HUMANOS \\ E A SEGURANÇA ALIMENTAR}

\section{CULTURA}

$\frac{\text { ACADÊMICA }}{\text { d ditona }}$ 
(C) 2009 Editora UNESP

\section{Cultura Acadêmica}

Praça da Sé, 108

01001-900 - São Paulo - SP

Tel.: (0xx11) 3242-7171

Fax: (0xx11) 3242-7172

www.editoraunesp.com.br

feu@editora.unesp.br

CIP - Brasil. Catalogação na fonte

Sindicato Nacional dos Editores de Livros, RJ

\section{M245i}

Maniglia, Elisabete, 1955-

As interfaces do direito agrário e dos direitos humanos e a segurança alimentar /

Elisabete Maniglia. - São Paulo : Cultura Acadêmica, 2009.

Inclui bibliografia

ISBN 978-85-7983-014-3

1. Direito agrário - Brasil. 2. Direitos humanos - Brasil. 3. Direito à alimentação Brasil. 4. Nutrição. 5. Política pública. I. Título.

09-6211.

CDU: 349.42(81)

Este livro é publicado pelo Programa de Publicações Digitais da Pró-Reitoria de Pós-Graduação da Universidade Estadual Paulista "Júlio de Mesquita Filho" (UNESP)

Editora afiliada:

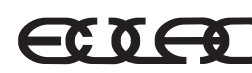

Asociación de Editoriales Universitarias de America Latina y el Caribe

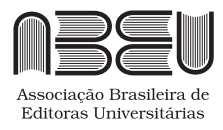


Aos meus filhos, Ricardo e Aloysio, fontes de inspiração, motivação de luta, meus grandes amores. 



\section{Agradecimentos}

Ao Espírito Santo, tão invocado e que sempre me atendeu, gerando inspirações.

Aos meus filhos, que me incentivaram.

À Viviane, minha filha, há 11 anos, que, dedicadamente, fez a correção do trabalho.

Ao Ricardo, que, pacientemente, manteve a infraestrutura para a realização deste livro.

À Prof ${ }^{a}$ Dr $^{a}$ Jete Jane Fiorati, pelo seu incontestável apoio para a realização deste trabalho e, sobretudo, pela sua luta ímpar no Programa de PósGraduação de Direito da Unesp.

Aos meus orientandos, Aderbal, Bariri, Dimas, Eli, Giovana, Jéferson, Juliana Avance, Juliana Xavier, Lana, Leandro, Marcos Castro, Marcos Rogério, Taisa, Tuco e Vinícius, que sempre me prestigiaram e que são sementes profícuas da minha luta. 

"É verdade que depois de derrubadas as cercas do latifúndio, outras se levantarão, as cercas do Judiciário, as cercas da polícia (ou das milícias privadas), as cercas dos meios de comunicação de massa. [...] Mas, é verdade também, que cada vez mais caem cercas e a sociedade é obrigada a olhar e a discutir o tamanho das desigualdades, o tamanho da opulência e da miséria, o tamanho da fartura e da fome." (Pedro Tierra) 



\section{SumÁrIo}

Apresentação 13

Introdução 15

1 O Direito Agrário e sua responsabilidade social 23

2 Direito Agrário e direitos humanos 67

3 Segurança alimentar 117

4 Das interfaces entre o Direito Agrário, os direitos humanos e a segurança alimentar no Brasil 175

Considerações finais 255

Referências bibliográficas 263 



\section{ApresentaÇÃo}

Este livro é o retrato dos meus ideais, meus anseios de vida e paixão pelo meio rural. No mestrado, defendi o direito de se lutar pela terra; no doutorado, a importância do trabalho rural; e, agora, defendo o direito de se ter segurança alimentar.

Em todos os trabalhos pretéritos, deixo clara a importância do Direito Agrário como instrumento de efetivação dos direitos humanos. Sempre vi a ciência jurídica como instrumento de justiça social e mecanismo de rompimento de desigualdades. Sempre preferi ficar ao lado dos oprimidos e deserdados da riqueza, do poder e do direito. Não consegui grandes honrarias em minha vida profissional, mas desfrutei do sorriso dos meus alunos, orientandos e pares, que lutaram, como eu, por um mundo melhor. Isso me bastou.

O meio rural foi sempre meu grande cenário. Apesar da dor, da miséria e da angústia da fome, é nele que se encontra a paz do silêncio, o gosto doce do fruto retirado da terra, da paisagem natural que encanta nossos olhos.

Foi no meio rural que escrevi a tese sobre segurança alimentar que resultou neste livro. Entre a imagem das montanhas de Minas Gerais e da fertilidade do solo paulista, estive atenta às comodidades e aos prazeres da vida agrária. Ouvindo o mugir da vaca separada da sua cria, ao lado do gato preguiçoso, que dorme sob o sol fraco da tarde, fui delineando os argumentos extraídos das leituras daqueles que clamam, como eu, pelo fim da fome.

Entre um bolo e um pãozinho feitos no forno à lenha, bebericando o cafezinho ou o chá de hortelã, de cidreira ou de camomila plantadas pelas minhas mãos, entre um sono e outro dormido na noite fria, com o céu 
mais estrelado do que o da cidade, esta pesquisa aqui desenvolvida ganhou forma.

Ao lado do riacho que corre em minha porta, com o cacarejar das galinhas, olhando para o pavão soberbo que desfilava aos meus olhos, fui buscando inspiração para terminar o trabalho, que me ocupou meses a fio, mas que me deu muito prazer ao ser findado.

Diante dos leitores, deposito meu tributo a favor do campo e do rural, e creiam que fiz quase o melhor de mim. Se falhei, perdoem-me; quero para a terra voltar. Plagiando o velho compositor, digo com o coração: "Foi lá que nasci, e lá quero morrer". 


\section{INTRODUÇÃO}

A proposta de se trabalhar com os temas Direito Agrário, direitos humanos e segurança alimentar nasce da experiência acadêmica e das ligações pessoais e profissionais com o meio agrário.

A maturidade profissional na pesquisa revela-se por leituras, experiências de vida, ensino, troca de posicionamentos ideológicos, conversas informais, participação em bancas, serviços de extensão e, acima de tudo, na construção diuturna do acreditar no que se pensa e no que se quer. Este trabalho, realizado na academia, reúne o apogeu de uma dedicada atividade, voltada para o meio agrário, na busca incessante de justiça para os que sofrem a humilhação da miséria e da fome que se desdobra em trabalho escravo, em trabalho degradante, dos que lutam pela terra para o sustento de suas famílias, dos que ambicionam por justiça, dos que têm sede de paz, dos que clamam por uma qualidade de vida e que encontram no Direito a última ratio para uma sociedade melhor.

Portanto, o material aqui reunido tem caráter científico, de pesquisa bibliográfica e descritiva, interessada em descobrir e observar fenômenos, procurando descrevê-los, classificá-los e interpretá-los. Apresenta, também, o conhecimento advindo da alternatividade, da construção do pensamento pluralista, que emana dos sábios sem letras, dos letrados sem cultura, dos pensadores idealistas, dos juristas renomados, unindo a construção de defensores do meio rural, cuja importância é basilar na construção da eficácia dos direitos humanos.

A construção da pesquisa foi buscada em fontes formais e informais, em trabalhos nacionais e estrangeiros. Buscaram-se modelos europeus, fontes 
econômicas, dados sociológicos, fontes do Estado, da sociedade civil e dos movimentos sociais, discussões nutricionais, posicionamentos médicos foi encontrado, inclusive, um grupo de pesquisa de médicos socais. $\mathrm{Pa}$ receres de engenheiros florestais e agrônomos permearam alguns trechos. A multidisciplinaridade foi uma constante. O entrelaçamento dos ramos jurídicos aparece a todo o momento, porém mais acentuado nas questões agrárias, ambientais e de direitos humanos, por ser este o nicho do trabalho.

Questionou-se o que já foi feito e o que se deixou de fazer pelo campo brasileiro. Os trabalhos editados pela pesquisadora voltaram-se para área rural, in totum. Cada tempo de vida foi aproveitado para conhecer, sentir a rotina agrária. As leituras de revistas agrárias, dos jornais voltados para o campo, os programas de televisão, os debates intermináveis entre os opositores do Movimento dos Sem Terra (MST) e da União Democrática Ruralista (UDR) foram analisados. Os reais e os pseudodiscursos de humanistas e até os processos internacionais de efetivação desses direitos constituíram-se fontes para a pesquisa.

A construção final do pensamento exposto é derivada do método dedutivo, que partiu do que foi proposto em modelos preexistentes, legais ou não, mas firmou-se na vida desta pesquisadora que sempre esteve, na prática, no convívio com o meio rural e com os que nele labutam.

O trabalho científico aqui elaborado foi buscado não apenas em doutrinadores (buscaram-se conhecimentos), mas também objetivou criar uma nova concepção jurídica para o tema escolhido, cujo centro é a segurança alimentar, que já havia sido tratada à luz de diferentes institutos, mas não à luz do Direito Agrário.

A escolha do tema está amplamente justificada pela trajetória de toda pesquisa, construída em vinte anos de carreira. Seguindo os ensinamentos de Angel (1980, p.1), a pesquisa ambicionou a investigação denominada sociojurídica, cujo propósito é a capacidade de poder questionar o Direito em termos políticos e com fundamentos empíricos, para que se aprenda a formular hipóteses normativas encaminhadas a produzir a troca de que necessita a sociedade. Parte-se do suposto caráter normativo do Direito como instrumento para produzir certos efeitos, dentro da realidade social: a investigação inclui a valoração do fim da norma e sua evolução, em termos de suficiência e adequação para alcançar os fins propostos, tendo em conta os elementos condicionantes da realidade social. 
Assim, o tema "segurança alimentar" é tratado partindo-se do princípio do direito à alimentação adequada, norma de direitos humanos, para sua análise na realidade brasileira, em face do Direito Agrário, responsável pelo controle da atividade agrária no País. A hipótese apresentada é que, embora o tema exponha interfaces naturais e indissolúveis, na prática, os interesses políticos e econômicos tornam a segurança alimentar prejudicada, desprezando conceitos jurídicos que garantem as necessidades fundamentais do homem.

As fontes formais foram utilizadas com base no fundamento do dever ser e também para se questionar seu fundamento, bem como as informais que brotam na realidade social, independentemente de haver quem as conheça. No entanto, quando existe um observador, a percepção que se tem desse fato passa a interessar sob diferentes pontos de vista. Nesse raciocínio, a segurança alimentar tornou-se o tema da pesquisa à luz do Direito Agrário e dos direitos humanos, com enfoque social amplo, por se acreditar que o direito não deve e não pode se limitar aos estudos meramente normativos legais.

A sustentação da hipótese da íntima relação entre o Direito Agrário e os direitos humanos, ao ser demonstrada, confirmará que a dignidade de uma vida humana se constrói com democracia e que esta se realiza por intermédio dos direitos a alimentação, educação, saúde, trabalho, moradia, meio ambiente saudável e, sobretudo, com paz e respeito pela diversidade cultural. Enfim, quem opta em viver no meio agrário, ou dele fazer sua atividade principal, faz jus a todos os direitos nele inerentes. No Brasil, onde muitos foram despejados de suas terras por um modelo perverso capitalista ou expulsos por um sistema escravocrata, monocultural, politicamente defensor do latifúndio, ou por razões de ordem de modelos firmados pelo mercado exportador, o da Revolução Verde, que até hoje perdura, forma sem dúvida, uma população sem acesso aos direitos humanos básicos, firmados em tratados ou convenções. Sem esses direitos, não há que se falar em democracia, em Estado de Direito, em paz social.

O desenrolar da pesquisa decorre da colaboração e orientação de trabalhos de iniciação científica e de mestrado, do convívio com a diversidade rural/urbano e, com certeza, dessa dialética, que muitos insistem em construir e que não deveria existir. Pode-se afirmar que o primeiro, o campo, sempre esteve em desvantagem, até na academia. Não foram poucas as ba- 
talhas para se impor um Direito Agrário num país rural. Difícil falar em Direito Agrário, como expressão da realidade quando muitos insistem em não aceitar a ciência jurídica agrária, porque ela incomoda institutos clássicos, como a propriedade.

É complicadíssimo discutir direitos humanos, uma vez que estes são processos em construção contínua, variando de realidade para realidade. No Brasil, entre a má interpretação de seu conteúdo até a má destinação orçamentária de recursos públicos para sua efetivação, o estudo dos direitos humanos oscila entre muitas versões. Nos trabalhos de extensão, foram observados discursos errôneos sobre esse tema e, pior, mesmo dentro do ensino jurídico. Há, ainda, os que se equivocam em falar sobre direitos humanos e também há os que acreditam que a implementação destes deva ser tarefa exclusiva do Estado, sem o comprometimento da sociedade civil. Vencida essa etapa, parte-se para a segunda meta: estabelecer o que o Direito Agrário pode fazer para a efetivação de direitos no Brasil.

O propósito do Direito Agrário é realizar a justiça social, que propiciará a certeza do alimento, o acesso ao trabalho agrário, quando este for a opção do cidadão e a responsabilidade em assegurar um meio ambiente saudável, que acarretará a responsabilidade da certeza da sustentabilidade para as futuras gerações. Nesse diapasão, constrói-se a linha da pesquisa que aborda o impacto que o Direito se propõe a gerar, em termos humanísticos e agrários, na teoria, o que ocorre na prática e o que pode mudar, se os operadores se propuserem a transformar o meio rural.

O Direito Agrário ganha novos rumos no mundo e transforma-se em peça fundamental na Europa para garantir mercados, sobrevivência e seguridade alimentar. A consolidação da União Europeia traz contornos novos para a ciência agrária que, consubstancialmente, converte-se, com o Direito Ambiental, em mola propulsora para a dignidade do cidadão. Os Estados Unidos apoiam a agricultura e, ante seus desastres ecológicos, preocuparam-se em criar políticas econômicas e mecanismos de defesa em face dos órgãos internacionais, a fim de garantir sua alimentação com leis protecionistas. Os países de Terceiro Mundo buscam sua sobrevivência, procurando produzir e vender cada vez mais, e são desejosos por leis agrárias de incentivo, crédito rural e pesquisa. Outra parte da população mundial, deixada de fora dos mercados competitivos, vivendo abaixo da linha da pobreza, fica com os restos dos demais e, orientada - ou não - por organizações 
não governamentais $(\mathrm{ONG})$ e movimentos sociais luta para garantir seu direito básico à vida, e, para tanto, necessita de leis que a assegurem para continuar vivendo.

Neste conciso quadro, tenta-se, por meio do presente trabalho, demonstrar que o Direito Agrário não se exclui em qualquer parte do globo. Está presente, positivado ou não, como realidade humana de direito fundamental e, portanto, deve ser conhecido em sua construção teórica e aplicada.

O primeiro capítulo cuida de apresentar esse Direito em seus princípios, formulações e institutos, tanto no direito estrangeiro como no brasileiro. Obviamente, a ênfase reside na construção crítica, numa postura dialética, chamando a atenção, inclusive, para o desprezo que lhe é deferido, com o intuito de que esse Direito, voltado para a justiça social, não incomode a elaboração de planos econômicos das classes produtoras tradicionais, as quais, dentro de seu egoísmo, ambicionam somente seu bem-estar. O Direito Agrário que, muitas vezes, nem sequer é estudado dentro das universidades deveria ser ciência obrigatória na vida dos cidadãos, fundamentalmente pela situação humanista que dele decorre, em clamar por dignidade de vida, de trabalho e de meio ambiente, em sentido amplo. As atividades agrárias, aqui expostas, transmitem o quão grande é o universo rural, possibilitando funções diversas a serem exercidas, geradoras de capacitação profissional para diversos setores.

A responsabilidade social, decorrente do Direito Agrário, entrelaça-se com a efetividade da garantia da vida, por meio da terra para se plantar, da dignidade do trabalho rural, da manutenção do meio ambiente e dos cuidados que devem ser mantidos, para que a natureza continue na sua missão de vida planetária. Não haverá meio ambiente saudável, se não existir agricultura responsável. Não existirá vida digna, se não houver alimento e meios para obter essa produção em quantidade suficiente para todos.

O capítulo seguinte dedica-se à análise dos direitos humanos e de sua implementação na realidade hodierna. Conceituam-se os direitos humanos, trabalha-se com sua evolução, com as políticas de sua efetividade e sua legalidade, composta de princípios constitucionais básicos. No entanto, o trabalho volta-se mais especialmente para a preocupação em torno de suas violações e suas decorrentes consequências, em níveis nacional e estrangeiro. Particularmente, no Brasil, o meio rural é o campeão em violações a direitos humanos. A grande concentração fundiária, a tradição escravocrata, 
a manutenção de políticas favoráveis aos grandes dominadores de terras, o desrespeito às normas legais agrárias, a grilagem de terras, a política depredadora do meio ambiente e as violações aos direitos trabalhistas revelam que o campo é palco das maiores atrocidades em pleno século XXI, gerando o paradoxo de que aquele que garante a vida é o que mais sofre com a desqualificação desta. $\mathrm{O}$ entrelaçamento entre o Direito Agrário e os direitos humanos se edifica na pesquisa, avaliando-se a realidade rural, com todos os seus acontecimentos, como omissões, a insensatez dos governantes ante os princípios da função social, que traz a discussão da questão econômica, trabalhista e ambiental. Assim, divide-se o segundo capítulo em subtítulos específicos, referentes à luta pela terra, pelo meio ambiente saudável, pelo trabalho digno e pela segurança alimentar. A paz no meio rural é discutida perante os conflitos surgidos da disputa pela terra, de forma velada e explícita. A paz mundial, dentro das rodadas da Organização Mundial do Comércio (OMC), mostra-se de forma intimidada quando se discute a questão dos protecionismos agrícolas, e, mais do que nunca, a paz mundial estará ameaçada quando o uso da água passar a ser controlado. O desemprego gerado no meio rural traz reflexos econômicos que geram violência; o trabalho escravo cria barreiras alfandegárias e inserções estrangeiras na economia local; organismos internacionais policiam o Brasil quanto às condições de trabalho nas lavouras de cana-de-açúcar; tarifas e rejeições de exportações são diuturnamente aplicadas aos produtos rurais brasileiros, por descumprimento dos padrões de segurança alimentar; a economia gira em torno das exportações agrárias, do Produto Interno Bruto (PIB), do poder de compra da população; a democracia concretiza-se por meio do acesso aos direitos e às garantias fundamentais; e a agricultura é uma mola propulsora para a melhoria das condições de vida e para a concretização da paz mundial. Dessa feita, a discussão perpassa pelos direitos humanos econômicos, sociais, ambientais e de solidariedade.

O terceiro capítulo trata da segurança alimentar, iniciando com a discussão do papel do Estado contemporâneo perante a fome e miséria. Discutem-se as políticas públicas voltadas para o atendimento dos mais carentes, a democracia, a pressão dos grandes grupos econômicos e suas estratégias para os mercados consumidores. Discutem-se o consumo exacerbado e as diferentes formas de sustentabilidade social, econômica e ambiental, trazendo-se a lume as variantes que recaem sobre a discussão acerca da relação 
entre produção e segurança alimentar. Em seguida, abordam-se a questão dos alimentos, dentro da esfera internacional, e seu importância à luz dos Estados de Primeiro Mundo, em particular da União Europeia, uma das mais afeitas a promover a segurança alimentar. É apresentado o histórico dos órgãos que cuidam do assunto: as reuniões, os tratados, as medidas legais para se discutir o tema e seus efeitos no mundo. A segurança alimentar passa a ser apresentada no Brasil, discorrendo-se sobre a insegurança alimentar, para, em seguida, discutirem-se as políticas públicas dos programas Fome Zero e Bolsa Família, as situações frágeis das regiões pobres e os novos objetivos do Direito, comentando-se a nova legislação.

O quarto capítulo retoma a discussão dos temas anteriormente descritos, buscando o inter-relacionamento dos direitos, numa visão conjunta dos direitos humanos, do Direito Agrário e de suas conexões com a segurança alimentar. O meio rural passa a ser abordado, realçando sua importância para a vida humana e para o Brasil, em especial, por ser o responsável pelo superávit da balança comercial. Mas, ao mesmo tempo, questiona-se a pobreza e a miséria nele existentes, analisando suas causas e os fundamentos da desigualdade. Sob a égide da democracia, busca-se verificar a história do campo, em face do desenvolvimento e dos índices de crescimento, em consonância com os direitos que garantem aos cidadãos a busca da dignidade. Destacam-se o papel das políticas públicas voltadas para o setor agrícola e os múltiplos deveres do Estado para favorecer a produção e atingir a segurança alimentar.

Os setores do meio rural são divididos, e demonstra-se que os grandes proprietários são sempre senhores de direitos maiores que os demais. Discutem-se a questão agrária e as políticas essenciais ao bom resultado do meio rural, e abordam-se o agronegócio e a reforma agrária, a agricultura familiar, o apoio às novas atividades rurais, como o turismo rural, as ocupações de fim de semana, os novos empregos gerados. Além disso, há questões referentes à migração, aos índios, aos quilombolas e povos excluídos, que padecem com a gravidade da fome e da miséria. Analisa-se o papel do MST e dos assentados na luta pela segurança alimentar, e, finalmente, é apresentada uma ampla discussão sobre o meio ambiente e seus desdobramentos vinculados à preservação da sustentabilidade da vida humana.

As conclusões são delineadas, mas não definitivas, uma vez que o tema ganha alterações a cada momento em que a realidade se altera. A segurança 
alimentar, à luz do Direito Agrário, é vista como um profundo estudo de políticas públicas que deverão ser realizadas e não somente por assistências, distribuídas nos locais mais pobres, que garantem o almoço malservido às famílias miseráveis. A importância dos programas governamentais é reconhecida como um paliativo, mas muito tem de ser alterado, estabelecendose um rearranjo de alta complexidade social. Muita boa vontade terá de ser demonstrada pelos Estados, e a luta pela democracia plena é o maior remédio para o mal da fome e da miséria.

A pesquisa na universidade propõe questionamentos, levanta dados, faz críticas e sugere mudanças. Entretanto, o cerne do trabalho efetiva-se quando a pesquisa, aqui demonstrada, ultrapassa o perfil individualista e ganha noções de grupo. Esta foi e continua sendo a proposta desta autora: clamar para o conhecimento agrário estudantes universitários de graduação, em princípio, e, em seguida, os de pós-graduação, com o intuito de estimular o estudo do Direito Agrário e dos direitos humanos, juntamente com o Direito Ambiental. A busca de um direito à alimentação adequada deve ocupar os bancos dos cursos de Direito, com discussões que façam crescer o sentimento de que, se existem pessoas com fome, é porque não há justiça; e se não há justiça, o direito nada, ou pouco, fez, e sua validade é questionada.

O sonho de um mundo melhor não tem idade e precisa ser passado de geração a geração, e a produção científica, em ensino jurídico, deve ser construída por meio da reflexão e da crítica, levando o aluno a conhecer a realidade para nela adentrar.

Aqui repousa o nosso propósito. 


\section{1 \\ O Direito Agrário e sua RESPONSABILIDADE SOCIAL}

\section{Considerações introdutórias}

É altamente prático lembrar que todos os ramos jurídicos clamam por justiça, e o sentido social está implícito em todos eles. Todavia, quando se fala em Direito Agrário, relembram-se a questão alimentar, a preocupação com a produção e a melhoria da qualidade dos produtos. Em seguida, associa-se a questão ambiental que impera na atividade rural, e passa-se a analisar os fatos diante da realidade mundial. Milhares de pessoas passam fome. Outros tantos morrem de desnutrição. Há crianças que não atingem um ano de vida por falta de alimentos. Há doenças crônicas causadas pela má alimentação. Grande parte da população está abaixo da linha da pobreza e alimenta-se uma única vez por dia. Há esgotos a céu aberto, água contaminada, problemas no ar que se respira, e a destruição de florestas, matas e fauna agrava-se dia a dia. Os últimos relatórios mundiais acerca do meio ambiente são assustadores. Diante de um cenário dramático, pergunta-se, de pronto, qual e a finalidade do Direito Agrário diante destes conflitos e qual é a sua contribuição em face dos problemas derivados do meio rural.

Se os propósitos do Direito Agrário pudessem ser aplicados automaticamente, sem manuseios de interesses políticos e de expedientes outros de favorecimentos pessoais, ou, ainda, sem a finalidade de atender a grupos privilegiados que desfrutam da terra como reserva de valor, o Direito Agrário seria, sem dúvida, um grande alento para questões sociais em geral e, especialmente, para aquelas relativas à fome, ao meio ambiente e à garantia, 
em parte, de direitos humanos tidos como essenciais, firmadores das necessidades básicas. Javier de Lucas (1998, p.12) comenta a importância de se discutir o conceito de necessidades, no raciocínio sobre justiça, tratando de oferecer uma fundamentação dos direitos humanos, desde as necessidades básicas. Roig (1994, p.12) também comunga dessa ideia, estabelecendo que existe um caminho que foi dos direitos às necessidades, para, hoje, retornar aos direitos. Assim, não há que se falar em direitos, sem se falar em necessidades; a comunhão entre eles se conecta por meio da justiça, que é, à luz do pensamento de Javier de Lucas (1998, p.14-5), inseparável da satisfação de necessidades tão vitais, como as de alimentação e moradia, o que basta para se prevenir que uma matéria não pode ser examinada num ambiente alheio a valores, sob a luz exclusiva de ordenamentos jurídicos interpretados de maneira puramente silogística do tipo hipótese-sanção.

Jacques Tavares Alfonsin (2003, p.59) defende que

[...] as necessidades vitais têm poder normativo capaz de se impor como indiscutível, sob todo o risco que essa palavra comporta, mesmo para garantir os efeitos jurídicos decorrentes dos direitos humanos fundamentais que lhes servem de conteúdo, é a de que sem a satisfação delas não há como se considerar garantidos o direito à vida e o direito à liberdade.

Assim, torna-se fundamental que o estudo jurídico de temas vinculados a direitos humanos, como aqui tratados, seja analisado sob a concepção de necessidades para se assegurar a busca da justiça. Neste ensaio, os institutos postos em discussão são a garantia da vida por meio de alimento em quantidade suficiente e de qualidade. Fator este que implica a discussão de direitos vitais, de direitos ambientais e da máxima discussão do Direito Agrário, gerador do estudo da atividade agrária controladora da produção, do meio ambiente rural e das condições sociais, daqueles que se envolvem na labuta da terra, com efeitos desencadeadores no meio urbano. Os temas agrário, ambiental, direitos humanos e segurança alimentar são a espinha dorsal de uma discussão que anseia provar que o Direito Agrário, desde que bem norteado e fiel aos seus anseios, é a grande solução para conflitos de fome, meio ambiente e vida mais justa.

Na concepção doutrinária, o Direito Agrário, conforme Sodero (1968, p.37), traz leis que são elaboradas por juristas especializados na matéria, 
visando fornecer meios legais para a administração pública planejar e executar programas em longo, médio e curto prazos para as atividades rurais. Programas que se fundamentem de maneira efetiva e justa, com vistas à elevação do nível de vida do homem rural e ao aumento da produtividade agropecuária. Essas leis são as que constroem o Direito Agrário e recaem sobre os mais diferentes institutos, sendo todos voltados para a melhoria da vida rural, abrangendo a política fundiária, mecanismos de acesso à terra e à política agrícola, instrumentos que garantem ao homem o manejo e uso do solo de maneira sustentável.

A responsabilidade social, dessa feita, fundamenta-se no princípio da função social da propriedade. Dessa premissa parte toda a teoria que estrutura o ramo jurídico em estudo, fazendo deste o princípio maior do Direito Agrário, que, aliado a outros princípios, tais como planejamento, inovação, justiça social, constitui seu grande objetivo, conforme Sans Jarque (1985, p.3):

A normativa agrária se encerra numa profunda força renovadora e criadora causal não abstrata, em especial a serviço da justiça e das necessidades humanas especiais e muito particulares dos homens. Em síntese, seu objetivo final é contribuir com justiça e dignificar os que vivem da terra do setor agrário, os profissionais da agricultura, cada vez mais deprimidos em relação à vida dos demais setores econômicos, garantir alimentação suficiente em quantidade e qualidade para todos os homens e assegurar o habitat e o equilíbrio ecológico da natureza em que vivemos e em que hão de viver as próximas gerações.

Como aqui demonstrado, o bem comum é parte integrante do uso da terra. $\mathrm{O}$ interesse social tem de estar demonstrado para garantir a proteção jurídica da terra. Mas não se centra a função social somente na propriedade, ela está ligada à atividade agrária que pode ser exercida na propriedade, na posse, no contrato de arrendamento ou na parceria. Deve-se ressaltar que o Direito Agrário brasileiro ainda trabalha com a divisão de terras e a reforma agrária, a ocupação e a disputa dos solos. De forma geral, o Direito Agrário europeu, norte-americano e de outros países, como Japão e Austrália, versa seus objetos de estudo para institutos de produção, segurança alimentar, proteção ambiental, crédito rural e cooperativismo, institutos hoje também contemplados pelos agraristas brasileiros, em parceria com os institutos vinculados ao uso e à distribuição da terra. 
A dimensão social do Direito Agrário, todavia, está presente em qualquer vertente estudada, e as atribuições dos proprietários ou de usuários da terra estão reguladas como obrigação, hoje, no Brasil, de caráter constitucional.

Toda atividade deve ter uma dimensão de produção racional e adequada, explorando-a racionalmente de acordo, com a técnica regional, respeitando as normas trabalhistas e ambientais juntamente com o Estado, que ao exigir esta obrigação do empresário rural deve permitir que ele tenha acesso, aos mecanismos de facilidades para o cumprimento da função social. Deve portanto fornecer crédito rural, armazenagem, vias de acesso ao escoamento da produção com boa qualidade (estradas), apoio técnico, incentivo a pesquisas, dispor de controle dos preços dos produtos condizentes com os gastos, estabelecer sempre que necessário preços justos e corretos para que o consumidor não seja lesado, disciplinando com isto o mercado produtor e consumidor. E permitindo ao empresário rural o desenvolvimento normal de sua atividade, o atendimento das legislações trabalhistas e ambientais, fiscais e outras. (Sodero, 1968, p.34)

Assim, o Direito Agrário adquire perfis diferenciados, porque, em sua essência, traz, conforme Ballestero Hernandez (1990, p.31), características que constituem o elemento típico do moderno Direito Agrário: a defesa dos economicamente mais débeis, a salvaguarda dos interesses gerais, o respeito às tradições e aos costumes, e, por último, a proteção da empresa agrária. Em consequência, o Direito Agrário adquire um caráter econômico, porque sua finalidade consiste em regular e ordenar a produção agrária, sistematicamente, seguindo as determinações do mercado e da justiça social, incrementando o constante nível de vida do meio rural. Percebe-se que o centro de preocupações se firma na técnica, no ofício e na arte de cultivar a terra, incluindo-se, aqui, todas as formas de atividade agrária, como agricultura, a pecuária, o reflorestamento, o extrativismo, a agroindústria, a hortifruticultura, em todas as suas modalidades e, ainda, quem sabe, o turismo rural.

Acresce-se a esse lado de responsabilidade social o sentido nacional do Direito Agrário, em que todo um país deve se unir, em princípios comuns, por meio de órgãos nacionais com políticas uniformes, considerando a atividade agrária como um serviço público. A melhoria das condições devem se filiar à produção agrária, à atividade industrial agrícola e à relação comércio-consumo. 
O caráter social e a responsabilidade do Direito Agrário são, como afirma Ballestero Hernandez (1990, p.32), de projeção supranacional, sem que se oponha ao sentido nacional. Todos os organismos internacionais devem se voltar para a preocupação, com fins de paz e melhoria de vida dos povos. Nessa visão, Weber (apud Henandez, 1990, p.33), economista espanhol, afirma que o Direito Agrário deverá ser um direito mundial; daí a necessidade de se impor uma cooperação efetiva internacional que alcance todos não numa visão utópica, mas numa unidade econômica, para que se corrijam os injustos desequilíbrios econômicos entre países pobres e ricos.

No Brasil, as atividades agrárias e o Direito Agrário passam, por vezes, despercebidos, numa política que faz crer que, se possível, o Direito Agrário deveria ser esquecido. Associam-se a ele políticas de reforma agrária, pressões de movimentos sociais, políticas de demandas sociais, que fazem que as elites conservadoras clamem por seu fim, não enxergando, nessa vital ciência, a importância que ela representa.

Nessa linha de conduta, comandada pela tradicional elite rural que domina a política brasileira, quer explicitamente, quer na camuflagem, construíram-se raízes profundas de preconceito para com aqueles que lutam por melhorias no campo. As leis agrárias foram construídas por pressões sociais, mas muito pouco do ambicionado foi cumprido. As leis existem, mas os poderes, poucas vezes, fazem valer esses preceitos. Por exemplo, há de se fazer valer o que a lei traz sobre a grilagem de terras, considerando criminosa essa prática; todavia, os jornais noticiam, diuturnamente, esse expediente. Certamente, alguém, inclusive dos Poderes (e, aqui, digam-se os três Poderes), beneficia-se com essas práticas. O recente caso da irmã Dorothy é um exemplo de luta pela terra, pelo meio ambiente, contra a grilagem. ${ }^{1}$ Teve repercussão internacional e causou constrangimento ao governo brasileiro. Tornou-se um caso de violação de direitos humanos em amplitude internacional. Trata-se de um dos muitos e muitos casos de violação penal, civil, agrária, ambiental, fiscal, trabalhista; uma violação grave de desrespeito aos direitos humanos, envolvendo a máfia do desmatamento, do uso indevido de terra devolutas, do tráfico ilegal de madeiras, do trabalho es-

1 Irmã Dorothy Stang, de origem americana, naturalizada brasileira, foi assassinada no Pará, em 2005, por um grupo de assassinos profissionais, a mando de um consórcio de grileiros de terras, exploradores de madeira clandestina, chefiado pelo fazendeiro Vitalmiro Bastos de Moura, o Bida, que foi condenado a 30 anos de prisão. 
cravo e da destruição ambiental. Revelam-se, assim, as contradições entre o real e o legal.

A origem do descumprimento do aparato legal traz a marca da nossa história, em que a oligarquia rural sempre fraudou o sistema vigente ou criou normas que a beneficiasse, mas que, num primeiro momento, se constituíam em marcas de paternalismo para os pobres do campo que, até certo ponto, acreditavam que os senhores da terra os protegiam e queriam o seu bem. Sérgio Buarque de Holanda (2005, p.160) lembra que os movimentos reformadores, aparentemente, partiram quase sempre de cima para baixo, e a grande massa recebeu essas mudanças com displicência ou hostilidade, pois, no fundo, não foram eles os agentes de mudanças, e estas não satisfaziam suas ideias. Neste erro de crença de que as leis resolvem conflitos, incorreram os políticos e demagogos que chamam a atenção, frequentemente, para as plataformas, os programas, as instituições, como únicas realidades verdadeiramente dignas de respeito. Acreditam que da sabedoria e da coerência das leis depende diretamente a perfeição dos povos e dos governos.

Desconhecem que as leis são norteadores e que as leis todas, sem exceção, devem ser cumpridas para que se garanta o respeito a elas. Entretanto, até hoje, no Brasil, exige-se dos pobres e dos oprimidos a obrigação de se cumprir as leis, mas o Estado ou mesmo os poderosos podem esquecê-las ou alegar artifícios para o seu não cumprimento. No meio rural, são milhares de exemplos que se somam a esse quadro, desqualificando a responsabilidade social do Direito em estabelecer normas de validade pública que melhoram e aprimoram a vida social.

Nesse pacto, vislumbra-se a análise do Direito Agrário como agente social de mudanças e transformações.

\section{Conceitos e conteúdo agrarista}

A história da agricultura, como lembra Del Vecchio (apud Gischkow, 1988, p.11), se não é contemporânea ao homem, será à civilização humana. Quando se fala em agricultura, remonta-se ao Direito Agrário porque não há como negar a vinculação de um ao outro. A produção de um bem agrícola traz, em seu teor, agregações econômicas, sociais e jurídicas. Porquanto o Direito Agrário, mesmo não sistematizado como ciência, existe 
como realidade, desde os primórdios, e, como leciona Artur Pio dos Santos Netto (1986), mesmo que não seja tratado de modo especial, constitui-se ele, sem dúvida, na maior parte de um direito sempre atual, desde as épocas mais remotas. Como todo ramo da ciência social aplicada, ele só pode ser compreendido num contexto histórico-cultural-político, diante de uma realidade em que se contextualiza não só a essência da atividade agrária, mas tudo o que influencia, provoca, determina e executa essa função vital para a manutenção da sobrevivência humana.

A discussão entre o nascer e o renascer do Direito Agrário, que ocupou grandes espaços intelectuais, quando a primeira revista dessa área foi lançada na Europa, ainda gera polêmicas, pois muitos civilistas atribuem o nascimento do Direito Agrário ao século XX, enquanto grande parte dos estudiosos agraristas (os mais tradicionais) defende que esse ramo sempre existiu, já que está ligado estreitamente à sobrevivência do homem. É sabido que o Código de Hamurabi, datado aproximadamente do século XVII a.C., trazia em seu bojo normas agrárias bem definidas. ${ }^{2}$ Previa ele, dentre outras normas, o cultivo do campo, e assim rezava seu artigo 43, conforme descreve Miranda (1989, p.38): "Se ele não cultivou o campo e o deixou árido, dará ao seu proprietário o grão correspondente à produção de seu vizinho, e, além disto afofará a terra e destorroará a terra que deixou baldia e devolverá ao proprietário do campo”.

Torna-se nítida a preocupação com a função social da terra aí descrita, o que marcou o primeiro documento a falar das coisas do campo. Outros artigos, contidos no Código de Hamurabi, também se preocupavam com o trabalho rural e com o homem que exercia essa função e com o meio ambiente, recomendando que quem cortasse uma árvore deveria plantar dez; dessa forma, esse documento foi o primeiro Código Agrário da humanidade.

A legislação Mosaica de 1400 a.C., no Velho Testamento, faz profundas remissões à terra e demonstra, desde então, a íntima e constante relação entre a religião e as questões agrárias, presentes até o momento hodierno. A passagem bíblica é precisa e revela a importância da propriedade da terra: "A justiça seguirás, para que vivas e possuas a terra que te dará o Senhor teu Deus".

2 O Código de Hamurabi traz diversas passagens que se ligam às questões de reforma agrária, função social da propriedade e defesa ambiental. 
O direito romano foi propulsor de leis agrárias. Por exemplo, consta na Tábua Oitava, 4: "Se urgem divergências entre possuidores de campos vizinhos que o pretor nomeie três árbitros para estabelecerem os limites respectivos".

As Ordenações do reino de Portugal obrigavam os proprietários rurais a explorar suas terras, sendo desse instrumento legal a definição das sesmarias, estabelecidas no Título 43, do Livro IV: "Sesmarias são propriamente as dadas de terras, casas e pardieiros que foram ou são de alguns senhorios e, que já em outros tempos foram lavradas e aproveitadas e agora o não são". ${ }^{3}$

Dessa forma, pode-se afirmar que as normas legais vertentes sobre o campo encontravam-se codificadas muito antes de o Direito Agrário vir a ser reconhecido como ramo jurídico. Na prática, também o Direito Agrário sempre foi uma constante, pois a primeira relação do homem é com a terra, pela garantia da sobrevivência. A caça, a pesca e a busca por frutos silvestres foram atividades sempre reguladas quer na Idade Primitiva, quer nos demais momentos em que imperaram as legislações supracitadas, e até mesmo na Idade Média, marcada pelas relações entre senhores, vassalos e Igreja, quando a terra se constituía no elo principal, sem, no entanto, haver normas codificadas. Como preleciona Ismael Marinho Falcão (2000, p.3), "a história do Direito Agrário remonta a história da humanidade e está continuamente ligada à agricultura”. Dessa forma, embora haja ainda quem negue a existência daquele (são poucos os desatualizados), pode-se afirmar que, como fato, o Direito Agrário inicia-se com a realidade humana, e, como ciência, seu nascimento se dá no ano de 1922, na Itália, quando todo material foi ordenado por Giangastone Bolla, que fundou a Rivistta di Diritto Agrário, impulsionando esse Direito para o caminho de ciência autônoma, aprimorando sua existência ao longo de sua trajetória. ${ }^{4}$

O Direito Agrário sempre foi questionado como ciência autônoma. Foi altamente combatido, principalmente pelos civilistas que não encontravam sua razão de ser, porque, no raciocínio destes, as atividades agrárias acon-

3 As Ordenações traziam também em seu bojo, outras preocupações com a terra, inclusive de ordem ambiental, porém, no Brasil, não foram aplicadas, a não ser o instituto das sesmarias e, assim mesmo, de forma desvirtuada.

4 Bolla foi considerado o fundador do Direito Agrário. Embora tenha sido um marco histórico sua compilação, compartilhamos do pensamento de que o Direito Agrário sempre existiu de fato e que, apenas como ciência, passou a existir a partir de então. 
tecem na propriedade, na posse, ou por meio de contratos, e estes institutos são próprios do Direito Civil, sendo esse ramo o mais importante do Direito, por ser altamente abrangente, podendo plenamente dispensar a função jurídica agrária. Também as questões públicas, num raciocínio simplista, poderiam ser resolvidas pelo Direito Administrativo; enquanto as trabalhistas, pelo Direito do Trabalho; outras, pelo Comercial; tantas mais, pelo Internacional, podendo, totalmente, ser eliminado este Direito voltado para o meio rural.

Partindo dessa posição, a corrente civilista atribuiu ao Direito Agrário a condição de braço do Direito Civil, sem autonomia, sem cientificidade própria, o que implicaria o fato de ele nunca existir como ramo jurídico. Porém, esse fato já se encontra superado atualmente, pois, em muitos estudos, prova-se que o Direito Agrário é muito mais público que privado, portanto não se trata de ramo do Direito Civil e nem do grupo do qual faz parte. Segundo Delgado de Miguel (1996, p.33):

O progressivo intervencionismo do direito público na fixação dos preços agrários, na orientação dos cultivos segundo as necessidades dos mercados até como garantia de funcionamento da atividade agrária, na normativa comunitária, na política de subvenções, no abandono de terras e nas limitações da produção, vem separando cada vez mais o agricultor do controle de seu produto, produzindo uma desvinculação entre agricultor e o resultado de sua atividade.

Isso, na prática, representa que a livre iniciativa está em declínio para determinadas atividades agrárias e, em certos países, a maioria de Primeiro Mundo, que o Estado passa a ser o senhor de muitas deliberações e intervenções, a fim de construir o interesse público, hoje, já de caráter global. Argumenta-se ainda que o Direito Agrário, responsável pela segurança alimentar do mundo, não pode ser tratado como ente privado e, se assim o for, deverá ter o Estado regulamentando sua produção e distribuição, desde que este opte por produzir para o bem geral, de forma democrática, atendendo aos anseios e às necessidades do povo.

Não há mais que se falar em Direito Agrário como braço do Direito Civil; essa superação é de caráter oficial em todo o mundo; a autonomia do ramo agrário e sua postulação como ciência são demonstradas no âmbito acadêmico, didático e pragmático de si mesmo. Hernandez Gil (apud Sanz 
Jarque, 1985, p.52) esclarece que o Direito Agrário, assim como outros ramos jurídicos, se entrelaça com institutos de outros Direitos e cita como exemplo o estudo da propriedade rural, que precisa de ser vista na ótica do direito real de propriedade, com origens no Direito Civil e, ao mesmo tempo, é objeto do Agrário, com a visão especialíssima deste ramo.

Fábio Maria De Mattia (1992, p.110) tem a visão certeira de que a presença do fundo rústico não pode ser considerada fundamental para o exercício da atividade agrária, pois basta asseverar que o cultivo sem terra para certos vegetais é o único tecnicamente possível e o único conveniente economicamente. Nesse mesmo sentido, Carrozza (1975, p.278) recorda as culturas hidropônicas ou aeropônicas e muitas outras cultivadas em ambientes especiais, como estufas e similares. Para esse agrarista italiano, pode-se observar uma crise da concepção fundiária da agricultura, a qual, muitas vezes, confundia o Direito Agrário com o Direito Civil. De Mattia (1992, p.107) observa que, na base da especialidade do Direito Agrário, se encontra sempre a ideia da possibilidade teórica e da conveniência prática de se separar a matéria fundiária, que corresponde ao Direito Civil, e a matéria agrária propriamente dita. Antonio José de Mattos Netto (1988, p.13) afirma categoricamente que o fenômeno agrário não deve ser estudado somente sobre a égide de normas civis, mas principalmente pelas normas de Direito Agrário.

Sanz Jarque (1985, p.51) conclui que o Direito, na verdade, é único, e falar em autonomia concebida em sentido único, para cada ramo jurídico, não tem sentido.O que deve ser respeitado é a sua especialidade e a matéria pertinente aos seus estudos e aos seus métodos, que são distintos, com peculiar conteúdo, fazendo dessa ciência a busca da ordem, do bem comum e da justiça, funcionando em cada país, adaptado à realidade e às necessidade locais.

Por conseguinte, o que estava por trás de ser o Direito Agrário um braço do Civil, ou não ser autônomo, era um conteúdo ideológico de defesa da propriedade, de não preocupação com o social e de fazer valer as questões econômicas, em detrimento dos ditames de interesse público e de defesa do coletivo. Há que se observar que as relações agrárias trazem em seu bojo o conteúdo da dominação e, portanto, sempre foram tomadas como defesa da propriedade em geral, independentemente das relações sociais advindas desse instituto. 
A resistência só foi rompida com a evolução histórica dos direitos humanos, com a importância de se valorizar o social, até mesmo para benefício de uma elite que poderia ceder parte de seus direitos para obter em troca uma série de benesses, como a tranquilidade de uma vida sem perturbações violentas, a defesa de um meio ambiente mais saudável, de uma qualidade melhor de alimentos, de uma paz firmada na evolução das comunidades. Obviamente, esse apogeu só é vivido em países que se qualificam de primeiríssimo mundo, como Suíça, Suécia, Holanda e Dinamarca, onde os povos optam em valorizar o social, clamam por altos índices de melhoria de vida e, com certeza, embutem a preocupação com seus alimentos por meio de suas produções ou priorizando as importações destes, como essenciais para a sociedade como um todo. Há de citar, como ilustração, que a Dinamarca só adquire madeiras brasileiras com certificado de produção sustentável.

Outros estágios do Direito Agrário são estudados, conforme a realidade local e seu nível de preocupação com o coletivo e com a qualidade de vida dos seus membros. Pode-se observar que a Comunidade Europeia, como um todo, volta-se para um estudo de Direito Agrário firmado na seguridade alimentar, na qualidade da produção, nas condições de quem produz e nos custos dessa produção e no meio ambiente onde ele é produzido. As regras jurídicas estão voltadas a regulamentar esses dispositivos. Os Estados Unidos também, em parte, equiparam-se aos objetivos europeus, diferenciando-se com a quase inexistência de uma preocupação ambiental. Outros países comungam dessas ideias, como Japão, Canadá, México, Austrália e Israel.

Muitos trazem, em sua base jurídica, um Direito Agrário dual: em estágio evoluído, preocupado com produção, tecnologia, agronegócio, mas sem conteúdo social, convivendo com uma realidade de luta por terra, conflitos constantes, preocupado ainda em realizar reforma agrária. O Brasil encontra-se nessa fase, assim como outros países latinos.

Há também países em situações piores, como grande parte dos africanos, outros como Haiti, onde a fome, a miséria, a exclusão agrária formam a dura realidade da vergonha mundial de admitir diante da explosiva produção de alimentos a morte de milhares de pessoas, que nunca conseguiram ser cidadãos, porque a vida lhes foi ceifada, em decorrência da falta de comida ou de meios econômicos para obtê-la. 
Desse modo, o Direito Agrário ocupa-se em tratar das questões agrárias em face da realidade sociojurídica de cada país, permeadas por prioridades políticas e seus objetivos. Esse é o Direito Agrário efetivado pela realidade.

Por outras linhas, há o Direito Agrário científico, autônomo, didático, e esses pontos merecem consideração in separado. Sob o ponto de vista da autonomia, não há mais que se discutir se o Direito Agrário é dependente ou não. Sua autonomia já foi exaustivamente tratada no direito estrangeiro e nacional. Segundo Evaristo de Moraes Filho (1969, p.22), "o conceito de autonomia de um ramo jurídico [...] quer significar somente a presença de um direito especial"; em virtude disso, também são especiais os seus princípios, a sua doutrina, os seus desígnios, os seus métodos. "A especialidade jurídica agrária no Brasil surgiu pouco a pouco a partir da elaboração de leis singulares sobre fenômenos agrários que faziam parte, secularmente, do arcabouço do Direito Civil e do Direito Administrativo."

Laranjeira (1999, p.251), no mesmo raciocínio, afirma que:

[...] a necessidade de se colocar num sistema próprio e coeso a legislação fragmentada sobre o mundo rural, que se esparzia noutras órbitas legais, terminou fazendo eclodir a autonomia legislativa do Direito Agrário, o que ocorreu com a Emenda n. 10, de 10 de novembro de 1964, à Constituição de Federal de 1946, ao dar competência à União para legislar sobre o citado ramo jurídico.

A autonomia didática veio dez anos mais tarde quando o ministro da Educação, por ato administrativo, colocou o Direito Agrário como objeto do ensino-aprendizagem nos cursos de Direito. Realce deve ser dado à Universidade de São Paulo que, em seu curso de pós-graduação em Direito, iniciou as aulas de Agrário, antecipadamente, com a presença do Prof. Sodero, que, mais tarde, consolidou a disciplina, inclusive na graduação. ${ }^{5}$

$5 \mathrm{Na}$ Universidade de São Paulo, precisamente no curso de Direito do Largo de São Francisco, nas aulas de pós-graduação, deram-se os primeiros ensinamentos de Direito Agrário. Passaram por essa cátedra nobres professores, como os saudosos Fernando Sodero, Paulo Guilherme de Almeida, Olavo Acyr Lima Rocha (que participou no doutorado desta autora), e ainda presentes naquela escola: Fábio Maria de Mattia (único professor titular de Direito Agrário do Brasil), Giselda Hironaka (todos foram docentes desta agrarista), Fernando Scaff (livredocente da USP) e o jovem Gustavo Rezek, todos com formação uspiana. Passaram ainda pela USP, como alunos, Antonio José de Mathos e Maria Cecília de Almeida, agraristas atuantes e companheiros na Academia Brasileira de Letras Agrárias (Abla) e na Associação 
Hoje, pode-se dizer que grande parte das faculdades tem, em suas estruturas curriculares, a disciplina de Direito Agrário. No entanto, muitos Estados não incentivam esse estudo por falta de docentes especializados ou por questões ideológicas. Há divergências sobre o seu conteúdo, e já se observou, em muitos locais, que o Direito Agrário, por não constar no rol das disciplinas obrigatórias dos cursos jurídicos, integra a graduação num curto período de seis meses, estabelece-se como disciplina optativa, ou, ainda, seu programa se restringe à parte contratual e à defesa da propriedade rural. $\mathrm{O}$ Ministério da Educação tem trabalhado muito com a tese da vinculação do conteúdo programático à realidade local do curso. Dessa forma, na maioria das cidades com características rurais, as escolas que apresentam propostas para abertura de cursos jurídicos, com a expectativa da aprovação, acabam por incluir a disciplina agrária, embora não entendam, algumas vezes, seu conteúdo ou objeto.

Felizmente, as universidades, em sua maioria públicas, optam por estudar o Direito Agrário no tempo de um ano, transmitindo um conteúdo crítico e detalhado, que perpassa por todos institutos agrários, permitindo que o profissional do Direito esteja apto a atuar em vários setores jurídicos, de forma convincente e justa. Hoje, também os concursos públicos, principalmente os da esfera federal, apresentam em seus conteúdos a disciplina agrária como parte de suas exigências, o que acaba por ocasionar o interesse pela matéria.

Por iniciativa da Associação Brasileira de Direito Agrário (Abda), ${ }^{6}$ está sendo motivado o ensino do Direito Agrário ao longo de um ano, ao menos

Brasileira de Direito Agrário (Abda). Na Unesp, muitos mestrandos e pesquisadores orientados por esta professora têm seguido a carreira agrária, divulgando esse ramo jurídico. São eles: Dimas Scardoelli, Juliana Xavier, Jéferson Celos, Marcos Rogério de Souza, todos mestres com trabalhos na área do Direito Agrário; além de Marcos Pereira de Castro, premiado duas vezes em suas pesquisas de iniciação científica e também como melhor trabalho nacional na referência mestrando pela Abda, e Taísa Cintra Dosso, mestrandos, e outros tantos pesquisadores da Fundação de Amparo à Pesquisa do Estado de São Paulo (Fapesp) e do Programa Institucional de Iniciação Científica (Pibic) que se dedicaram ao estudo do Direito Agrário com afinco na sua graduação.

6 A Associação Brasileira de Direito Agrário (Abda), com sede em Goiânia, promove esse Direito por meio de congressos e reuniões, e conta com o apoio imensurável de Maria Célia dos Reis, procuradora do Instituto Nacional de Colonização e Reforma Agrária (Incra) e uma batalhadora das causas agrárias, em conjunto com Helio Novoa, outro grande agrarista e também procurador desse instituto. Em Goiânia, está presente o mestrado da Universidade Federal de Goiânia (UFG) que formou inúmeros mestres em Direito Agrário. 
na graduação, com amplo programa que trata das questões públicas e privadas de tal ciência. Junto aos cursos de pós-graduação, tem crescido a procura por pesquisas na área rural, com vertentes aos movimentos sociais e também ao Direito Ambiental, contudo há registro de muitos trabalhos que pesquisam exclusivamente o Direito Agrário nas mais diferentes questões.

A questão ideológica se faz presente no item didático, uma vez que muitos docentes ou discentes se envolvem com a divisão de terras no Brasil, associando as questões das lutas dos movimentos sociais sobre a ocupação do solo brasileiro e suas reivindicações constitucionais. Nesse diapasão, incluem-se dados sociológicos justos que motivam e orientam uma melhor postura do direito diante das questões agrárias. Entende-se que essas ocupações, protestos, lutas ${ }^{7}$ devem, sim, se constituir como institutos do Direito Agrário, uma vez que todos eles clamam por efetivação de direitos, negados por séculos. Afirma-se essa postura declarando a importância deste estudo como ilícito civil? Como assunto sociojurídico? Como direito negado à maioria dos povos brasileiros? Como direito de protesto? Como crime? Enfim, este capítulo novo, mas tão antigo em sua essência, integra o novo programa de Direito Agrário sim, apesar de alguns agraristas quererem ignorar as pressões e lutas. Essas situações têm como fim a justiça, e os que trabalham com esta devem estar preparados para agir nessas lides.

A autonomia científica consolidou-se com os trabalhos dos juristas envolvidos nas pesquisas, com análise histórica da evolução dos conceitos, teorias e institutos agrários. Há trabalhos dos estudiosos, com ideologias arcaicas, tradicionais, fiéis às oligarquias rurais que acreditam fielmente na propriedade absoluta e na manutenção do direito da defesa do latifúndio, da monocultura e da economia de exportação. Como há também os pensadores agraristas com viés social, preocupados com injustiças seculares, em defesa dos que trabalham a terra, dos que a valorizam como meio de sobrevivência, de luta pela erradicação da fome, viabilizando produção de alimentos. Uma nova bandeira integra essa luta, a dos que ambicionam um Direito Agrário mesclado com o Direito Ambiental, na busca pela preservação das matas, do solo, das florestas, organizando um direito sustentável. Uma si-

7 O Movimento dos Sem Terra (MST), apesar de hoje estar numa posição, em parte, criticável, é um grande responsável na luta pela terra. Conseguiu grandes modificações na estrutura jurídica e faz pensar o direito plural. 
tuação está ligada à outra. A cientificidade cresce com luta e obstáculos, mas ganha posturas de ciência jurídica. A criação da Academia Brasileira de Letras Agrárias (Abla) $)^{8}$ é a manifestação real da preocupação dos agraristas em divulgar seus trabalhos e trocar experiências entre regiões. O Direito Agrário cresce como doutrina e pesquisa, ampliando seus horizontes.

Pontes de Miranda (1983, p.248) descrevia em sua obra que "a ciência do direito é o todo de conceitos e enunciados com que pode o jurista apanhar o sentido histórico das regras e das instituições, sentido atual e toda natureza da categoria jurídica ou da regra, no quadro científico".

Assim, ver ciência é mais que enxergar uma parte, requer toda uma estrutura de investigação e conhecimento do ordenamento do próprio direito positivo. É conhecer um todo de realidade, costumes, normas, aspirações de uma comunidade - no caso em tela, a rural. Porquanto, faz-se valer do pluralismo jurídico para uma melhor compreensão e eficácia. Entende-se como pluralismo a oposição ao unitarismo determinista do materialismo e do idealismo moderno, pois advoga a independência e a inter-relação entre realidades e princípios diversos. Parte-se do princípio de que existem muitas fontes ou fatores causais para explicar não só os fenômenos naturais e cosmológicos, mas igualmente as condições de historicidade que cercam a própria vida humana (Wolkmer, 2001, p.172).

Nesse sentido, o Direito Agrário deve ser constituído de uma visão com base na tolerância, em que há conflitos de interesse, diversidade cultural, religiosa, histórica, costumeira, em que se nega que o Estado seja a única fonte exclusiva de todo o Direito. Como ensina Wolkmer (2001, p.183), trata-se de uma visão antidogmática e interdisciplinar que advoga a supremacia de fundamentos ético-sociológicos sobre critérios tecnoformais. Assim, minimiza-se ou exclui-se a legislação formal do Estado e prioriza-se a produção normativa multiforme de conteúdo concreto, gerada por instâncias, corpos ou movimentos organizados semiautônomos que compõem a vida social.

Vale afirmar essa importância do pluralismo jurídico para todos os ramos do Direito, mas em especial aqui para o Agrário, onde as culturas re-

8 A Abla foi uma criação dos agraristas, por iniciativa de Alcir Gursen, Altir Maia, Darcy Zibetti, Lucas Barroso, Elisabete Maniglia. Reúne agraristas de todo o Brasil, e cada membro tem um patrono, e o desta autora é José Gomes da Silva. 
gionais e os costumes se interpõem, fazendo comunidades rurais das mais diferentes espécies. Vale lembrar os movimentos sociais que ditam soluções, de grupos ambientalistas que lutam, de ONG, de associações, de participações civis em órgãos públicos e outros tantos setores que intercedem pelo Direito Agrário, construindo uma gama de relações jurídicas nem um pouco desprezível.

A conceituação de Direito Agrário não pode ser estática, urge por mudanças na sua aplicação, mas seu conteúdo vem com a visão clássica de autores célebres, como Sodero (1968, p.32) que assim explicita sobre esse ramo: "Conjunto de princípio e normas de Direito público e privado que visa disciplinar as relações emergentes da atividade rural com base na função social da terra”.

Segundo Raymundo Laranjeira (1981, p.58): "Direito Agrário é o conjunto de princípios e normas que, visando imprimir a função social à terra, regulam relações afeitas a sua pertença e uso e disciplinam a prática das explorações agrárias".

De acordo com Ballarin Marcial (1975, p.441):

O Direito Agrário é o sistema de normas, tanto de Direito privado como de Direito público, especialmente destinadas a regular o estatuto do empresário, sua atividade, o uso e a tendência da terra, a unidade de exploração e a produção agrária em seu conjunto, segundo princípios gerais peculiares a esse ramo.

Segundo Rodolfo Carrera (1978, p.5):

O Direito Agrário é a ciência jurídica que contém os princípios e as normas que regulam as relações emergentes da atividade agrária, a fim de que a terra seja objeto de uma eficiente exploração, alcançando uma maior e melhor produção, assim como uma mais justa distribuição da riqueza em benefício dos que nela trabalham e da comunidade nacional.

Daí, pode-se afirmar que os conceitos, embora variáveis, refletem a tendência para o cumprimento da função social, para o bem-estar do homem do campo, para o aumento da produção por meio de leis, princípios e normas, realidade social, de natureza pública e privada, tendo como objeto a atividade agrária. 
O espaço rural é o centro aglutinador de toda atividade agrária, de seus sujeitos, do agricultor, de seus elementos materiais, exploração e produto agrário, e de sua atividade comercial, incluindo o mercado agrário, os frutos e os alimentos como elementos de intercâmbio desse mercado.

Essa nova abordagem que inclui a atividade agrária como principal centro do Direito Agrário, sendo acompanhada das atividades acessórias que se interligam a esse ramo, justifica a nova faceta do Direito Agrário da Comunidade Europeia, que reflete um novo dinamismo crescente desse ramo do Direito, atento à real situação da agricultura, à sua exploração, à empresa, à agroalimentação voltada para explorações eficientes, por meio de métodos de produção e cultivo com respeito ao meio ambiente, que compreende cultivo vegetal e animal.

A nova tendência dos mercados, voltada para a produção de produtos orgânicos, também clama por tendências legais diferenciadas e por formas de abastecimento regulamentadas. Há de se considerar que o Direito Agrário deve estar atento a todas as formas de atividades agrárias e que a função social da propriedade poderia até ter, muitas vezes, um aspecto mais moral do que jurídico; mas, hoje, essa posição está realmente combatida e superada, pois, segundo Marcial (1991, p.67), a moderna teoria da função social é eminentemente jurídica, pois trata de conseguir um sistema de normas que obriga os proprietários a empregar sua riqueza de forma que não prejudique os interesses da coletividade. Essa obrigação vincula-se logicamente a tipos determinados de bens, aqueles que estão ligados ao bem comum.

Delgado de Miguel (1993, p.45) aponta que a nova vertente do Direito Agrário confirma um dinamismo que se converte na multiplicidade e variedade da norma jurídica agrária, que deve estar atenta sempre à necessidade real e às configurações de situações. Para tanto, o espaço rural converte-se no centro aglutinador de toda atividade agrária de seus sujeitos, do agricultor, de seus elementos materiais, de exploração e do produto agrário diante do mercado agrário, dos frutos e alimentos, como elementos desse intercâmbio. Assim, mais que produzir, é necessário estar atento ao sistema produtivo para atender a todas as demandas do consumidor e à qualidade que é exigida. Para tanto, é necessário formar um empresário agrário profissional, coerente com as modalidades ambientais, disposto a enfrentar desafios que não prejudiquem os interesses da coletividade.

A empresa agrária, para Scaff (1997, p.46), é a atividade organizada profissionalmente em um estabelecimento adequado ao cultivo de vegetais ou 
à criação de animais, desenvolvida com o objetivo de produção de bens de consumo. De Mattia (1995, p.51) lembra que

[...] para ser empresário agrário não necessita ser proprietário produtivo, pode ser empresário o possuidor, o usufrutuário, o arrendatário, o concessionário de terra, o parceiro outorgado. Ocupa hoje a empresa agrária um lugar de destaque no horizonte rural, pois ela está adstrita à função social e tem um sentido muito mais amplo que o definido no Estatuto da Terra no seu artigo 4, inciso VI.

Há de se falar, hoje, que a empresa agrária reúne o estabelecimento agrário, o empresário agrário e a atividade agrária. Constitui-se no objeto central do Direito Agrário, porque nela se fundem a atividade agrária, as pessoas e os bens envolvidos na prática dessa atividade. Com base nesse ponto de vista, a empresa agrária pode ser integrada pela pequena propriedade, pela média e pela grande propriedade, independentemente de seu capital ou de sua constituição jurídica.

\section{Princípios e características do Direito Agrário}

Como observado, a atividade agrária constitui-se no cerne do Direito Agrário. Não são a propriedade rural, a reforma agrária ou os contratos o seu objeto de estudo. Estes últimos são estudados pelo Direito Agrário, porque contemplam a atividade agrária de uma forma direta ou indireta. Outros autores apontam a importância da atividade agrária para o funcionamento da empresa agrária, devendo, apenas nesse contexto, ser considerada. Como a atividade agrária é exercida ou onde ela tem criação é elemento importante para o Direito Agrário, assim como a política agrícola que permite o sucesso dessa atividade e toda a infraestrutura que lhe dá condição. Esse é conteúdo pleno do Direito Agrário, e a atividade agrária orienta seu estudo.

Para caracterizar uma atividade como agrária, recorre-se a estudos pretéritos estrangeiros que, no Brasil, foram denominados por Giselda Hironaka (1997) como teorias clássicas da caracterização da atividade rural.

Carrera (1978, p.6) elaborou a teoria denominada "agrobiológica", fazendo, em linhas gerais, uma coesão entre o agronômico e o jurídico, asso- 
ciando a terra e a vida como fatores diferenciadores da atividade rural, em relação às demais atividade humanas. A atividade agrária existe, a seu ver, quando se realiza na terra, quando o homem explora a terra para fazê-la produzir, por meio de um processo agrobiológico, os frutos destinados para seu consumo direto. Nesse entender, o homem é elemento essencial para a produção e, consequentemente, para a atividade agrária.

Carrozza (1988, p.80), por sua vez, defendeu a teoria da agrariedade, em que afirmou existir uma noção extrajurídica que caracteriza qualquer instituto jurídico como agrário. Dá a introdução da noção de risco na ideia do processo agrobiológico, defendido por Carrera. Seria agrária toda atividade cujo ciclo biológico estivesse sujeito às intempéries da natureza, que escapam ao controle humano. Segundo essa teoria, mesmo que haja um ciclo biológico na terra, mas totalmente controlado pelo homem, essa atividade não será caracterizada como agrária. Onde incidisse o controle do homem com calor, luz, técnicas artificiais, essas não seriam consideradas atividades agrárias.

A terceira teoria tida como clássica é a teoria da acessoriedade, de Vivanco (1967, p.20-1), que entende como agrárias, além da atividade típica de produção rural, aquelas decorrentes de índole econômico-social. Sua principal intenção foi verificar quando a atividade industrial ou comercial está sob o manto da atividade agrária e quando são independentes dela. Nesse sentido, estabeleceu alguns critérios para tal distinção, como necessidade, relevância, autonomia, normalidade, ruralidade e acessoriedade. Pelo critério da necessidade, é agrária toda atividade imprescindível ao cultivo do solo e à criação de animais, de maneira que abarca todas as atividades de transformação e venda de produtos, pois são necessárias às atividades produtivas. O critério da prevalência nasce como uma crítica ao da necessidade, à medida que a transformação e a venda, ao assumirem a predominância sobre a atividade de cultivo e criação, passam a se revestir da natureza de atividade industrial e comercial, respectivamente.

Já o critério da autonomia determina que uma atividade é industrial ou comercial quando os atos de transformar e vender puderem se realizar de forma autônoma à atividade de cultivo e à criação de animais.

Por sua vez, o critério da normalidade disciplina que a atividade agrária é aquela realizada normalmente no cotidiano agrário. Noutra linha, o critério da ruralidade apregoa que a atividade é agrária quando se relaciona à vida e ao trabalho agrícola, determinada com base na localização do imóvel. 
Por fim, destacou o critério da acessoriedade, que dá nome à teoria, segundo o qual a transformação e a venda serão atividades agrárias quando forem complementares às atividades de cultivo e criação (produtiva).

Vivanco (1967, p.21) apresentou sua classificação das atividades agrárias:

- Próprias: produtiva, conservativa e preservativa.

- Acessórias: extrativa e capturativa.

- Conexas: manufatureira, transportadora, processadora, lucrativa e a consuntiva e atividades agrárias vinculadas às demais, que se interrelacionam.

No que tange à análise das teorias, pode-se considerar que cada teoria apresenta um pouco de verdade, mas não há prevalência de uma sobre a outra, nas adaptações à realidade de cada país. Olavo Acyr Lima Rocha (1999, p.42-3) considera que

[...] as teorias clássicas, devem ser analisadas tendo-se presente, outrossim, a evolução histórico-científica e legislativa de cada país com suas condições próprias de tempo e lugar, bem como a constante evolução técnica e tecnológica do Direito e das ciências afins.

Helio Roberto Novoa da Costa (2001, p.40) considera que a prevalência deve ser atribuída à teoria de Vivanco (1967, p.20-1), abraçando o critério da acessoriedade, pois, no Brasil, há a carência de um critério ou de uma teoria tipicamente brasileira.

No Brasil, a atividade agrária vem delineada em diferentes diplomas legais e torna-se motivo de controvérsia quando apreciada por jus agraristas. O Estatuto da Terra trata de dizer, em várias oportunidades, da exploração extrativa agrícola, pecuária ou agroindustrial, a saber: $\operatorname{artigos} 1^{\circ}, 4^{\circ}, 5^{\circ}, 10^{\circ}$, 25, 47, 75 e 92.

Conforme Dimas Scardoelli (2004, p.30), o Estatuto da Terra utilizouse da noção de atividade agrária na determinação de muitos outros institutos, embora não tenha definido legalmente o instituto jurídico da atividade agrária. Na mesma linha, o autor diz que outros diplomas legais elencam atividades tidas como rurais, sem defini-las. São os casos da Instrução Especial Incra $n^{\circ} 5$, de 1973, e de algumas leis que versam sobre tributos relacionados à atividade rural. 
A primeira, em seu artigo $3^{\circ}$, apregoa que os tipos de exploração rural no Brasil são enquadrados nas classes de hortifrutigranjeiros, lavoura permanente ou temporária, pecuária e florestal. A Lei nº 8.629/93, em seu artigo $4^{\circ}$, reza sobre exploração agrícola, pecuária extrativa vegetal, florestal ou agroindustrial. No âmbito tributário, o artigo $2^{\circ}$ considera atividade rural a agricultura, a pecuária, a extração e a exploração vegetal e animal, a apicultura, avicultura, cunicultura, suinocultura, sericicultura, piscicultura e outras culturas animais. Ainda, a transformação de produtos decorrentes da atividade rural, sem que haja alteração da composição e das características do produto, o cultivo de florestas que se destinem ao corte para comercialização, consumo ou industrialização. O decreto tributário n ${ }^{\circ}$ 4.382/2002 versa sobre Imposto Territorial Rural (ITR), e seu artigo 18 descreve as mesmas atividades agrárias já mencionadas, o que faz afirmar que os dispositivos não são conflitantes quanto à eleição de atividades tidas como rurais.

Na realidade brasileira, outras dúvidas surgem quanto à criação de animais para esporte, prestação de serviços de equoterapia, aprimoramento genético, serviços de coleta de sêmen. Animais para esporte e lazer, jardinagem, sementes para plantio, culturas hidropônicas e agroturismo. Seriam essas atividades agrárias? Todas elas vinculam-se ao aspecto agrário, mas não são tratadas como tais para fins de tributação e outras considerações jurídicas. No entanto, trazem a característica do meio rural, o que, dentro das teorias, faria que pudessem ser consideradas atividades agrárias acessórias, e o Direito Agrário poderia incidir sobre elas, conforme entendimento hodierno. Nesse entendimento, uma vez ampliado o leque das atividades agrárias, o meio ambiente, principalmente, estaria mais bem protegido, assim como estar-se-ia diante de outras opções de frentes de trabalho rural, valorizando, dessa feita, o que José Graziano da Silva (1996) sempre defendeu como uma reforma agrária não essencialmente agrícola. ${ }^{9}$

Quanto ao turismo rural, Maniglia (1999), em outros trabalhos, defende a ideia de que este deverá ser incluído no rol das atividades agrárias, pois reflete um compromisso com o local, os costumes rurais, a natureza e a paisagem rural, reflete, enfim, o caráter agrário em seu âmago (Scardoelli, 2004,

9 Esse trabalho será reapreciado ao longo deste livro. Consiste em equacionar a questão do nosso excedente populacional com uma reforma agrária que permita a combinação de atividades agrícolas e não agrícolas, com a vantagem de usar menos terra e mais opções de emprego. 
p.30). Ademais, o turismo rural é encontrado em qualquer ponto do Brasil, e essa atividade movimenta o social, o econômico e o ambiental, motiva o comércio de animais em geral, estimulando a atividade agrária como fonte de emprego e atração sustentável, fomentando a permanência, inclusive do homem, no campo e atraindo outros para esse local.

Descrito o cerne do Direito Agrário, é de se considerar que as características que motivam o Direito Agrário vêm por meio da política agrária, que deve ser uma atividade ideológica, motivada pelo bem-estar da coletividade, uma atividade ordenadora da vida social, pela qual um grupo de pessoas e instituições influi ou direciona as demais para novas formas de conduta. Deve ser eminentemente prática, com tendência teológica para atingir fins. É instável porque sofre com as mudanças permanentes de caráter histórico, tecnológico e social, mas seus fins são os mesmos.

Os meios para desenvolver seus objetivos são múltiplos. O sistema estatal deverá estar sempre atento aos ditames constitucionais dispostos nos princípios jurídicos gerais de cada Estado. O Brasil traz a marca da constitucionalização do Direito Agrário e das políticas de reforma agrária, política agrícola e agrária. Portanto, as fontes são as leis, os costumes, a jurisprudência, a dogmática, os clamores sociais, as praxes hegemônicas, e tudo mais que refletir nos anseios sociais.

No que tange aos princípios, recorre-se aos ensinamentos de Laranjeira (1981, p.169) que elenca, na doutrina nacional, os seguintes princípios fundamentais:

a) princípio do aumento da produção e dos níveis de produtividade;

b) princípio do asseguramento de justiça social;

c) princípio da privatização das terras nacionais;

d) princípio da proteção à propriedade familiar camponesa;

e) princípio do dimensionamento eficaz das áreas exploráveis;

f) princípio do estímulo à produção cooperativista;

g) princípio do fortalecimento da empresa agrária;

h) princípio da proteção à propriedade consorcial indígena.

Sodero (1968, p.14) e Paulo Torminn Borges (1998, p.7) destacam, como princípio fundamental, a função social da propriedade, e o segundo autor enfatiza o progresso econômico e social do rurícola, o combate aos mercenários da terra, à exploração predatória e ao desenvolvimento do sen- 
timento de liberdade e de igualdade com implantação de justiça distributiva. Na doutrina estrangeira, vale lembrar que os princípios de cooperação e de organização profissional são vistos por Jacques Audier (2002, p.3-4) como fundamentais para vencer as barreiras impostas pelo mundo rural, que se apresenta diferente, heterogêneo e sob mutações. Ademais, o Direito Agrário, na Europa, traz a marca da conformidade comunitária que, para o autor citado, visa à modernização e ao desenvolvimento da agricultura, à adaptação ao contexto comunitário e internacional, à adaptação ao mercado competitivo capaz de exportar regramento e desenvolvimento do território, ao equilíbrio dos espaços rurais, à proteção do meio ambiente e à participação na luta contra a fome do mundo.

Em nível nacional, acredita-se que a função social da propriedade, por tratar dos elementos econômicos, sociais e ambientais, seja a tônica do Direito Agrário, pois a exigência desse cumprimento implica a perda da propriedade que não respeita - ao menos sob o ponto de vista constitucional (art. 184, Constituição Federal - CF) - esse dispositivo, que consolida grande parte dos princípios aqui descritos. Há de se considerar, ainda, que outros ditames constitucionais devem ser observados quando se trata de princípios agrários, como os objetivos do Estado, as garantias fundamentais, as metas para a iniciativa privada, as propostas ambientais, tributárias e empresariais, sem deixar de levar em conta os anseios sociais manifestos nas lutas da sociedade civil.

Rafael Mendonça de Lima (1997, p.45), apoiado nas lições de Vivanco (1967, p.184), afirma que o Direito Agrário é dependente da política agrária, que seria uma ação de planejamento do poder público. A política agrária tem de ter um fundamento jurídico, e, nesse caso, o fundamento jurídico é extraído do Direito Agrário positivo que é elaborado para atender a essa política. Conclui, pois, que a formação dos princípios do Direito Agrário tem íntima relação com a política agrária e esta com os dados da sociologia rural, da agronomia e de todas as ciências que importam à atividade agrária.

Umberto Machado de Oliveira (2004, p.135), em sua obra recente, discorda do pensamento desses juristas e justifica:

Com a devida vênia que o autor merece e está muito bem acompanhado dissentimos de seu pensamento por uma convicção simples: não admitimos que os princípios agrários sejam frutos da Política Agrária, mas sim que a Política 
Agrária seja elaborada em respeito e observância aos princípios do Direito Agrário. Sabido é que o substrato jurídico - uma lei ordinária é indispensável para implementação, pelo Poder Executivo, da Política Agrária, a qual está sujeita a influências momentâneas de caráter ideológico. Não podemos admitir, pois, que os princípios de Direito Agrário encontrem sua origem na Política Agrária ou que o Direito Agrário incorpore os princípios nela eventualmente inseridos.

Comunga-se, neste trabalho, com o referido pensamento, com a ressalva de que, sob o ponto de vista teórico e científico, nada mais coerente do que o proposto pelo autor; todavia, na prática, muitos países desprezam os princípios do Direito Agrário quando firmam suas políticas agrícolas, favorecendo os grupos econômicos, as políticas internacionais neoliberais, ou, ainda, elaboram leis coerentes com os princípios agrários, mas as ignoram.

Em se tratando de Direito Agrário europeu, há que respeitar as normas comunitárias que dão outras características a esse ramo, que estabelece preocupações múltiplas com o meio ambiente, a organização profissional e a segurança alimentar do mundo. Elementos estes que, no fundo, em nada diferem dos elementos constitutivos da função social brasileira, descrita no artigo 186, da Constituição Federal pátria, com a diferença de que, lá, são rigorosamente cumpridos e, aqui, ainda se encontram na luta para sua efetivação.

Conclui-se, então, que o Direito Agrário, hoje, é um ramo autônomo, didático e cientificamente independente, com princípios bem delineados, tendo por base o estudo da atividade agrária, com características específicas do meio rural, trazendo a marca da agrariedade e tendo como meta o estudo de múltiplos institutos, a saber: atividade agrária, reforma agrária, contratos agrários, propriedade rural e suas intercorrências, cooperativismo agrário, crédito rural, lutas sociais por terra, movimentos sociais pela melhoria do homem do campo, trabalho rural, meio ambiente agrário, seguridade alimentar, qualidade de produção e todos os reclamos que nutrem a questão jurídica agrária. Os institutos variam de país para país, respeitando as exigências territoriais e as necessidades locais, sem, todavia, deixar de ambicionar os ditames internacionais de padrão de qualidade e quantidade de alimentos e os meios para sua produção, organização e comercialização dos produtos agrários. No Brasil, seu estudo é abrangente, tomando em conta a preocupação fundiária e a política agrícola, reunindo, assim, mais institutos que os demais países, uma vez que ainda não superou sua fase de ocupação democrática do solo. 


\section{A função social do imóvel rural na legislação brasileira}

\section{A Constituição de 1988 na visão agrarista}

A Constituição de 1988 trouxe esperanças e promessas de liberdades e direitos sociais coletivos bem definidos, e criou perspectivas da construção de uma sociedade que, ao menos, ansiava por metas solidárias e maior igualdade. Indubitavelmente, a Carta Magna de 1988 deixou, em princípio, a certeza de que a democracia, a dignidade da pessoa humana e a construção de uma cidadania estariam sendo metas prioritárias. Em razão disso, pode-se confirmar na construção do artigo $3^{\circ}$ que, categoricamente, afirma serem objetivos fundamentais a construção de uma sociedade livre, justa, solidária, seguida da erradicação da pobreza e da marginalização, com redução das desigualdades sociais.

Mas não foi só; outros avanços democráticos podem ser vislumbrados na construção dos direitos fundamentais, na definição das políticas públicas relativas à saúde, à educação, à previdência, à assistência social, aos direitos coletivos, à definição das políticas públicas e na conceituação da função social da propriedade como garantia coletiva. Na lição de Miguel Baldez (1998, p.161):

[...] deve ser entendido que os princípio adotados pela Constituição constituem fundamentos e, por serem fundamentos, deles decorrem, além dos direitos individuais, os novos direitos sociais, os do regime relativo ao trabalho e,os direitos sociais coletivos como saúde, educação, previdência social, exigindo-se por outro lado do Estado para a concepção desses ditos direitos coletivos sociais a adoção de políticas públicas adequadas.

Dessa feita, não basta criar intenções; fundamental é criar metas e atitudes, para que se efetive a boa vontade, proclamada no texto constitucional, o que passa a ser exigido nas legislações infraconstitucionais e na construção de normas, decretos, portarias, consubstanciando a manifestação política para o cumprimento das metas determinadas no texto legal. Mas, se, em sua maioria, o texto constitucional de 1988 efetivamente ganhou avanços democráticos, pode-se apontar, como grande exceção e como uma das vitórias mais desprezíveis do setor oligárquico, a questão da reforma agrária 
que, impedida de entrar com força total, trouxe em seu bojo o artifício da produtividade, demonstração da força dos setores dominantes e atrasados, contrariando a democratização da terra e a eliminação das desigualdades rurais (Maniglia, 2005, p.27).

Com sabedoria, Fachin \& Silva (1990, p.58) assim explanaram, acerca da Constituição de 1988, no que tange à reforma agrária:

Pode-se afirmar, em breve resumo, que a Constituição Federal de 1988 (CF) no tocante à questão agrária, avançou na forma e recuou no conteúdo. De fato, pela primeira vez na história das sete Constituições brasileiras o setor agrícola mereceu um tratamento diferenciado, compondo capítulo próprio, o III, do título VII, da Ordem Econômica e Financeira. Trata-se, contudo de mera embalagem, escondendo mercadoria de baixa qualidade. Já que no mérito a Nova Carta contrariou a tendência histórica que vinha aperfeiçoando sucessivamente os instrumentos impositivos da Função Social da Propriedade Rural e os mecanismos de redistribuição fundiária retornando ao patamar da CF de 1946. Não foi preciso sequer o day after para se saber que os trabalhadores rurais e os sem terra em particular, pagaram os avanços que a CF de 88 consagrou em benefício de outros segmentos da sociedade brasileira.

A partir da constitucionalização da questão agrária, pode-se dizer que uma nova etapa rural se iniciou. Polêmica difícil de ser resolvida em matéria jurídica, mas compreensível em termos históricos sociais, no que tange à elaboração das leis agrárias.

Num rápido passeio histórico, há de se observar que as leis agrárias sempre foram, em sua maioria, discriminatórias, favorecendo o segmento patronal. A Lei de Terras de 1850 se, por um lado, criou a propriedade rural, protegendo-a, por outro, impediu o acesso à terra aos negros e aos pobres, quando obrigou que as terras públicas, doravante essa data, fossem somente vendidas. ${ }^{10}$ A abolição da escravatura, em 1888, foi um ato leviano, da maneira como foi celebrada, obrigando os ex-escravos a trabalharem por

10 Sobre o assunto, ver Laranjeira (1984, p.42) e Abinagem (1996, p.24). No dizer de ambos, e com a concordância desta autora, a Lei de Terras foi uma cilada preparada pela oligarquia rural para evitar que os escravos libertos pudessem ter acesso à terra e não se constituíssem como mão de obra barata para os senhores do café. José Graziano da Silva (1990, p.24), com relação ao tema, afirma o seguinte: "terra livre não combinava com homem livre". 
salários vis e de forma degradante, o que reflete em nossa realidade hodierna. ${ }^{11}$ A Consolidação das Leis Trabalhistas (CLT) de $1943,{ }^{12}$ em seu preâmbulo, deixou explícito que os trabalhadores rurais estavam excluídos da proteção trabalhista então instituída. Além disso, a inexistência de um Código Rural, por séculos, foi a grande manifestação de que o silêncio reforça a dominação e, ainda, de que, quando as elites elaboram as leis, estas, em sua maioria, são emitidas para não serem cumpridas. José de Sousa Martins (1999, p.70), ao tratar da questão, deixa claro que o jogo político na elaboração das leis, envolvendo questões opostas, responde pelo modo contido como as reformas sociais e políticas são concretizadas no Brasil:

[...] que além de tudo seus executores são quase sempre seus inimigos. O que talvez explique por que decisões políticas fundamentais ganhem forma legal até sem grandes dificuldades, mas emperrem justamente na sua aplicação, vitimadas e esvaziadas pela conduta conspirativa de uma burocracia pública que ainda age predominantemente a partir de orientações pessoais dos chefes políticos e não a partir da impessoalidade pressuposta no cumprimento formal da lei por parte do empregado público.

A questão, portanto, não é de aprovar leis avançadas, mas assegurar que elas não serão executadas contra os interesse dos que as aprovaram.

Sob essa análise, percebe-se que o texto constitucional traz em seu bojo legislação avançada quando trata da função social, com ênfase em diversas passagens, inclusive no âmbito dos direitos e garantias fundamentais (art. $5^{\circ}$, XXII e XIII), quando deixa claro que a propriedade é protegida, mas que terá de cumprir sua função social. Todavia, no texto agrário, embaraça a questão e cria uma antinomia ao, inicialmente, determinar que toda propriedade que não cumprir a função social será desapropriada (art. 184), para, em seguida, vetar a desapropriação nas terras produtivas, pequenas e médias. Reafirma-se, dessa forma, que o legislador avançou, criando uma

11 A má ocupação do solo brasileiro começou com as sesmarias, mas agravou-se com a Lei de Terras, pela discriminação proposta por ela, cerceando o acesso dos pobres à terra, prática ainda existente no Brasil e motivo da luta dos movimentos sociais.

12 A exclusão dos trabalhadores rurais foi uma traição do Estado. Esses trabalhadores só foram regulamentados em lei, na prática, em 1973, pois o Estatuto do Trabalhador Rural, de 1963, não entrou em vigor. 
expectativa de cumprimento de função social, mas, em seguida, arrependido, preocupado em desagradar grupos aliados, veta, de forma bastante parcial, o que seria o interesse da maioria.

Revela-se que, na questão agrária, pioradamente à opinião de Martins (1999, p.71), o legislador deu a esperança (função social a ser cumprida) e, ao mesmo tempo, a retirou, criando a artimanha da propriedade produtiva, para não ser aplicada a integridade da função social àqueles que haviam celebrado a benesse de legalizar constitucionalmente a propriedade com o dever de cumprir função social. Observa-se e torna-se necessário esclarecer que, na maioria das vezes, assim como foi na Constituinte, os que aprovaram as leis tinham interesse direto e pessoal, haja vista a pressão feita pelos deputados da ala da União Democrática Ruralista (UDR), responsáveis pela inclusão das terras produtivas no texto constitucional, obstruindo, assim, a reforma agrária ampla, participativa e cidadã.

Por sua vez, os poucos defensores dos trabalhadores rurais e sem terra, num esforço conjunto de luta social, ganharam no novo texto a inclusão do artigo 186, que descreve, de forma quase repetitiva, o que já havia sido explanado no Estatuto da Terra, no que se refere ao cumprimento da função social da propriedade rural, mas colocando em primeiro plano a produtividade, seguida dos elementos ambientais e sociais. A função social, como expressada no texto constitucional, sem conexão com os demais artigos, fica solta no sentido de se definir se ela deve ser cumprida na íntegra, por todas as propriedades ou se, independentemente de seu cumprimento, a propriedade produtiva, a pequena e a média não serão desapropriadas. Do modo confuso como foi expresso (ao que tudo indica, de forma dolosa), a propriedade que não cumprir função social, no que se refere à questão ambiental ou aos direitos trabalhistas, poderá estar livre de desapropriação se for produtiva, jogando, assim, por terra toda a ideologia da obrigação, derivada da ideologia da função social, ideologia esta aceita e contida em todas as legislações modernas. Isso permite que absurdos, como o trabalho escravo, sejam flagrados em uma propriedade ou que uma devastação ambiental seja cometida, mas, se ambos os ilícitos ocorrerem em propriedades produtivas, estas não serão desapropriadas. Fatos esses rotineiramente flagrados e sem processos desapropriatórios, fundamentados no princípio constitucional. O resultado de sua obrigação somente advém se utilizadas técnicas de hermenêutica, a partir das quais fique demonstrado que o ordenamento jurídi- 
co é um todo; portanto, ao se proceder à leitura dos direitos e das garantias individuais, estes deverão ser aplicados em todo o corpo constitucional, o que nos faz concluir que a propriedade rural deverá cumprir o descrito no artigo 186, com o detalhe básico da exigência de simultaneidade para todos os itens, o que ficará demonstrado ao longo desta pesquisa, que esta foi outra falácia do operador legal. Pode e deve o Poder Judiciário executar essa obrigação, porém, na maioria dos casos, o que acontece é o desrespeito aos demais itens da função social, privilegiando o item econômico.

Entretanto, nem só de desacertos foi elaborado o texto agrário. Seria de uma injustiça similar à dos constituintes proceder o jus agrarista somente com críticas ao texto constitucional. Há de se lembrar que, apesar dos desencontros, a elaboração de um capítulo destinado à questão agrária na Constituição (Título IV, da Ordem Econômica e Financeira, Capítulo I, arts. 184 a 191) ao menos demonstrou um tratamento diferenciado para os problemas rurais, bem como um vislumbre do estudo agrário para os estudantes que, muitas vezes, lamentavelmente, se limitam, por força curricular (não possuem a disciplina Direito Agrário na organização curricular), a estudar as leis agrárias via Constituição Federal.

Outro bom fundamento constitucional foi definir a função social para o imóvel rural (art. 186, CF). Embora essa definição não seja cumprida da maneira correta, o esclarecimento norteia os que lutam para seu cumprimento e sua efetivação no texto legal contemporâneo, já que sua postura constitucional coloca, ao menos, o Brasil em pé de igualdade com constituições estrangeiras, que, além de adotarem o procedimento desde 1919, perpetuam, na cultura jurídica de seus povos, a cultura da propriedade rural com função social, enterrando como um todo o sentido absolutista da propriedade.

A instituição do processo expropriatório para as glebas que cultivam plantas psicotrópicas (art. 243, CF) externou a vontade do legislador em cooperar com o fim do tráfico internacional e, de maneira mediata, colaborou com a questão agrária, permitindo o acesso de famílias para assentamentos em regiões que cultivavam folhas vistas como tóxicas. Sob o ponto de vista jurídico, é de se frisar que, embora a propriedade seja passível de garantias, neste caso, exclusivamente, o expropriado não receberá nenhuma indenização, conforme o determinado posteriormente na Lei n ${ }^{\circ} 8.257 / 1991$, regulamentada pelo Decreto n ${ }^{\circ}$ 577/92. 
Interessante também, pela primeira vez, o emprego correto da expressão "expropriação", uma vez que esse instituto significa a retirada do bem sem indenização e que, no Brasil, foi e continua sendo empregado como sinônimo de desapropriação, inclusive no processo desapropriatório - Lei Complementar $n^{\circ} 76 / 93$ que, ao se referir ao desapropriado, neste caso, passível de recebimento de indenização, o qualifica como expropriado, como se assim fosse sujeito praticante de delito de plantio de drogas. Por mais que o erro tenha sido mantido, o momento da expropriação qualificou o significado correto do instituto, permitindo um melhor entendimento da questão.

A demarcação das terras indígenas dentro de cinco anos (art. 231), a partir do texto da Magna Carta, foi repleta de boas intenções e merece aqui o aplauso que, de início, pareceu reparar o erro histórico do débito para com os índios. Mas, com o passar dos anos, essa demarcação não se consolidou, gerando os problemas vigentes. Os poucos índios restantes, excluídos da exterminação sofrida, rebelam-se pela devolução de suas terras, transformando o que era uma simples obrigação de fazer, numa luta entre poder local, poder federal, luta política, manipulação de inverdades, que, mais uma vez, demonstram o quão dura é a luta pela terra neste País.

Em que pesem os comentários de boas intenções sobre a Constituição, na questão agrária, há de se concluir que o dano da propriedade produtiva, constante na Constituição Federal, introduziu, na prática, a inviabilidade do cumprimento pleno da função social da propriedade rural, sem contar que as dificuldades de ordem legal, agronômica e operacional inviabilizam a recuperação e a efetivação plena dos direitos humanos no campo. Enquanto o mundo pede paz, o campo brasileiro vivencia uma guerrilha interminável, contabilizando mortes, conflitos, disputas judiciais sem sentido para um país rico em terras e produtor de uma safra de grãos recorde. A aplicabilidade real da função social da propriedade carece do apoio da Justiça e da sociedade como um todo, para que, ao fim, esta não pereça diante do desemprego, da fome e dos danos à natureza.

\section{A função social da propriedade}

Trabalhar com a ideologia deste fundamento - função social da propriedade, que tem suas origens em 1789 como princípio, mas que remonta ao instituto da propriedade já trabalhado anteriormente por Aristóteles que 
contestava a ideia de Platão - é viajar no tempo, em busca de um verdadeiro sentido para a propriedade e até para sua própria existência. De acordo com Rosalina Pereira (1993, p.105):

Para Platão, na sua obra A República, este defendia uma forma de organização social comunista em que os bens de uma sociedade pertencessem a todos os membros dessa sociedade, enquanto Aristóteles, na Política, defendia que os bens existiam para a satisfação das necessidades dos homens, contudo, a maneira mais eficaz de se assegurar a destinação social dos bens é através da apropriação pessoal. Para ele, era preferível que os bens pertencessem aos particulares que o usariam de maneira a satisfazer às necessidades da comunidade, ou seja, os homens têm o direito de usar os bens não só para sua própria manutenção, como para satisfazer a coletividade.

A contraposição sobre o instituto da propriedade caminhou em discussão, mas o que prevaleceu foi, durante tempos, a ideia da propriedade privada absoluta, marcada pelo direito romano. Na evolução histórica, o feudalismo marca a propriedade sem caráter exclusivista, conforme Rosalina Pereira (1993, p.106): "o domínio se reparte em domínio eminente (Estado) e domínio direto (Senhor) e domínio útil (vassalo)”. No entanto, segundo Arnoldo Wald (1991, p.15), "houve quebra da exclusividade do domínio, mas o poder político manteve-se ligado a ela, com exploração do homem trabalhador".

Surge o pensamento de Santo Thomaz de Aquino que, em sua obra Summa theologica, afirma:

O Homem para garantir as sua própria sobrevivência tem um direito natural ao apossamento dos bens materiais, logo o direito de propriedade resulta desse direito natural de apropriação dos bens, na luta pela sobrevivência, contudo esse direito de propriedade é limitado pelo bem comum, é limitado pelo direito que têm todos os homens de viver condignamente. (apud Pereira, 1993, p.107)

Ao fim do sistema feudal, em face das insatisfações do intervencionismo estatal aliado à desigualdade social, à intolerância religiosa, à política mercantilista e aos privilégios ditados pela política, surge a revolução liberal, marcada pelos pensadores iluministas que se posicionaram novamente em 
situações dialéticas diante do instituto da propriedade. Segundo Ferreira Filho (1982, p.32):

Locke, como Rousseau, afirmaram que a propriedade é o mais sagrado dos direitos, porque estavam vendo na propriedade o fruto principal da liberdade humana. Nesse raciocínio é que a declaração dos Direitos do Homem e do Cidadão em 1789 tenha insistido duas vezes sobre a propriedade, como pressuposto de liberdade, igualdade e fraternidade. Todavia, se a propriedade foi vista como a razão de ser da sociedade, foi também vista como origem da desigualdade e dos males sociais. Rousseau defendia essa tese, que foi desdobrada posteriormente pelos socialistas com destaque para Proudhon, que condena a propriedade como fonte de desigualdade e consequentemente de males sociais. A crítica mais importante e mais conhecida à propriedade privada é devida a Marx, para este, a propriedade privada é fonte de alienação e, na verdade, todos os males sociais em resumo, derivam dessa situação de alienação que sente o produto frente ao bem produzido e a solução seria a eliminação da propriedade, o que ocasionaria a eliminação das classes e a reconciliação do homem com o homem, permitindo uma sociedade sem Estado, na qual simplesmente houvesse uma coordenação das atividades sociais.

No antagonismo do liberalismo, que defende a propriedade como razão de ser da sociedade, em face ao socialismo, que vê a solução dos males no seu fim, surge a posição doutrinária da Igreja que recupera os estudos de Santo Tomás de Aquino, seguida pelos estudos dos positivistas, na figura maior de Comte e na célebre encíclica de Leão XIII, Rerum Novarum, cujo raciocínio afirma que a propriedade é um direito natural, inclusive a propriedade dos bens de produção, mas que esta não pode se destinar a satisfazer os interesses do proprietário, a trazer-lhes benefício, significando, também, uma maneira de atender às necessidades de toda a sociedade. Isso faz concluir que o exercício da responsabilidade do proprietário constitui uma das condições das liberdades civis e ainda que a propriedade passa a ser um direito do proprietário, associada ao dever simultâneo do cumprimento da função social. Daí decorre o que Ferreira Filho (1982, p.33) afirma:

A função social tem um efeito positivo de atribuir obrigações sociais ao proprietário: é a associação da função social ao sentido jurídico da propriedade. E 
o sentido negativo que não se admite mais propriedade absoluta. Nega-se por completo esta concepção.

Essa ideologia social pertinente à mudança dos tempos repercutiu no Direito Constitucional e foi incluída na Constituição do México, em 1917, pela primeira vez num diploma jurídico. E, em 1919, na Constituição de Weimar, na Alemanha, fixando a partir de então um novo padrão para as declarações de direitos, no que respeita ao direito da propriedade. Interessante é que, a partir de então, a propriedade vista somente do lado privado passa com sabedoria, no dizer de Bandeira de Mello (1984, p.39), a

[...] integrar o direito público e desde logo o constitucional, pois dependendo do tratamento dispensado ao direito de propriedade um estado será socialista ou capitalista, com todas as implicações daí decorrentes. Trata-se, portanto, de um direito modular à caracterização político social do Estado e, por isso de todo o quadro jurídico da sociedade: logo um direito público, por excelência.

O Brasil trouxe a discussão da função social da propriedade, pela primeira vez, na Constituição de 1934 e, de uma forma muito tímida, no artigo 113, estatui ser garantido o direito de propriedade que não pode ser exercido contra o interesse social ou coletivo. A Carta de 1937 é silente e a de 1946 enseja a manifestação da possibilidade da desapropriação pelo interesse social (art. 141) e, ainda, que a propriedade será condicionada ao bem-estar social (art. 147) e que a lei poderá, com observância ao disposto no artigo 146, promover com igual oportunidade para todos a justa distribuição da propriedade. Nas Cartas de 1967 e 1969, a evolução na linguagem normativa e, finalmente, ao dispor sobre o pagamento da desapropriação para imóveis rurais, ambas tratam da função social da propriedade. Mas o verdadeiro coroamento da função social da propriedade se dá na Constituição de 1988, manifesta em seu artigo 5º XII e XVIII, como cláusula pétrea, alinhavando a propriedade como um direito e a função social como dever inerente a ela. Ainda classifica a Carta Magna, em seu artigo 170, II e III, a propriedade privada e sua função social, como princípios da ordem econômica, impondo sanções para o caso de não ser observado, principalmente, em relação a propriedades imóveis urbanas e rurais (arts. 182 a 191). 
Mas, na realidade, a função social instituída constitucionalmente visa, no dizer de Lessa Giordani (1991, p.50),

Fazer com que a propriedade seja utilizada de maneira normal, cumprindo o fim a que ela se destina, o que não gera contraposição entre os interesses individuais e coletivos. Ao contrário, compatibiliza-os e representa, outrossim, uma harmonização da instituição com os fins legítimos da sociedade.

Vê-se, claramente, que a propriedade continua garantida como expressão de direito. Cabe, no entanto, um dever para seu proprietário, dever esse vinculado a um elemento econômico, a um elemento social e a um outro ambiental, pois estes foram os tópicos desenhados no artigo 186 para expressar o cumprimento da função social da propriedade rural. Para tanto, será necessário qualificar o imóvel rural, o que se fará doravante.

\section{Imóvel rural}

Há de se observar que, no transcorrer deste trabalho, sempre foi usada a expressão "agrário" e, neste momento, fala-se em imóvel "rural". Expressão esta usada pela Constituição e por tantas leis agrárias que usam os termos como sinônimos, para uns, com diferenças sutis, para outros, ou ainda percebem suas diferenças, mas não dão a elas importância jurídica ou pensam que essa confusão de termos não pode permanecer. Gustavo Rezek (2007, p. 45), em recente trabalho, assim se posiciona:

No moderno direito agrário não se pode aceitar tal mistura, aquilo que se diz rural será aceito e estudado no Direito Agrário só enquanto instrumento para a realização da atividade agrária, objeto de nossa disciplina. Para o agrarista não podem se encontrar no mesmo patamar o rural e o agrário, o rus e o ager. $\mathrm{O}$ primeiro é garantidor do segundo e sua importância é fundamental.

Seguindo esse raciocínio, o autor continua em defesa de sua tese, dizendo que o imóvel, chamado rural pela legislação agrária, é precisamente o imóvel agrário que encontra seu conceito legal no Estatuto da Terra e na Lei $n^{\circ} 8629 / 93$ que regulamenta a Constituição.

Para Laranjeira (1975, p.68), as expressões "rural" e "agrário" vão formar dois universos paralelos de uma só realidade; diversificando seus pró- 
prios significados, terminam por mostrar os dois aspectos fundamentais que são a razão de ser da própria disciplina jurídica estudada. Outros autores, como Octávio Alvarenga (1985, p.9), Olavo Acyr Lima Rocha (1992, p.79) e o próprio Rezek (2007, p.48), optam por separar os termos, destinando "rural" para a localização do imóvel fora da área urbana, na zona rural; e o termo "agrário", para os imóveis que se destinam à atividade agrária. Rezek (2007, p.49) cita, como exemplo, que a localização na zona rural não é essencial para a caracterização do imóvel agrário. Um hotel-fazenda será rural, mas não agrário. Um terreno urbano, onde se plantam hortaliças que serão vendidas no mercado, será agrário, mas não rural. Ruralidade e agrariedade são campos distintos que, quase sempre, cruzam-se e convivem num mesmo imóvel. Olavo Acyr Lima Rocha (1992, p.80) lembra que a maioria dos imóveis agrários está situada na zona rural, e os que permanecem na zona urbana, com destinação agrária, tornam-se, com o tempo, antieconômicos por não poderem exercer sua função agrária.

A discussão entre "agrário" e "rural" fica um pouco sem sentido, já que o Direito se denomina Agrário, inclusive por normatização internacional, porém parte da legislação usada pelo Direito Agrário tem em seu corpo a expressão "rural". Também os múltiplos recursos sociológicos despendidos pelo Direito Agrário falam em "rural”, o que leva a concluir que a separação dos termos, ou sua utilização, deve ser desenhada com os cuidados devidos, principalmente com o bom senso. De nada vale dizer que apenas deve se referir a "agrário", quando a legislação fala em imóvel "rural", propriedade "rural". Com esse raciocínio, entende-se que a postura de Laranjeira (1975, p.70) é a mais certeira, principalmente quando defende que se deve manter o termo "agrário", repelindo-se o "rural" sempre que possível.

No âmbito legislativo, existe um conflito entre os critérios atribuídos pelo Direito Tributário e pelo Direito Agrário, para caracterização do imóvel como rural ou urbano. O primeiro contempla a localização para definir o pagamento do tributo, ou seja, se sobre o imóvel deverá incidir o IPTU (imposto urbano) ou o ITR (imposto rural). Já o Direito Agrário estabelece como critério diferenciador entre um imóvel urbano e um rural a destinação de cada um. Desprezando toda a polêmica ocorrida nos anos 60, quando houve diversas bitributações, decorrentes dos conceitos diversos sobre o mesmo bem, chega-se, hoje, ao consenso de que as prefeituras deverão delimitar a zona urbana e a zona rural de cada município, conforme 
o disposto no Estatuto da Cidade e, na ausência deste, em sua lei de zoneamento urbano, verificando seu planejamento urbanístico. Obviamente que o bom senso e a racionalidade deverão ser elementos indispensáveis nesse planejamento, pois não se pode admitir que uma área de terras produtiva se localize em zona urbana e pague IPTU, em decorrência de a cidade ter se acercado dela. São casos cada vez mais raros, mas que clamam pelo bom senso. Como já dito alhures, esses imóveis acabam perdendo sua função agrária pela impossibilidade de continuar exercendo suas funções e acabam se transformando em loteamentos urbanos, pois, ficando circundados por bairros periféricos, enfrentam problemas de toda ordem.

Delimitar o urbano e o rural torna-se imprescindível para fins legais, pois, da definição de imóvel rural, advirão consequências típicas deste.

[...] a importância fundamental é a que advém dos efeitos da incidência de direitos e obrigações tais como: fins tributários, para a elaboração de contratos agrários, para fins de desapropriação por interesse social para, usucapião constitucional, para normas de fracionamento do imóvel rural, para determinação do rito processual, para fins de empréstimo rural e para não incidência de penhora por pequena propriedade rural. (Luz, 1993, p.25)

Particularmente, aqui interessa a ligação do imóvel rural com o cumprimento da função social da propriedade, o que implica o cumprimento do princípio para que esse imóvel não sofra a desapropriação. É específico o texto constitucional, no artigo 184, ao dispor que será passível de desapropriação o imóvel rural que não esteja cumprindo sua função social para fins agrários. Nesse contexto, vale a definição de imóvel rural determinada pela Lei $\mathrm{n}^{\circ} 8.629$, no artigo $4^{\circ}$, que o conceitua como “[...] o prédio rústico de área contínua, qualquer que seja a sua localização, que se destine ou possa se destinar à exploração agrícola, pecuária, extrativa vegetal, florestal ou agroindustrial".

Para Otávio Mello Alvarenga (1977, p.64), a descrição do imóvel rural implica dizer que:

Inicialmente, o termo prédio rústico é reminiscência romancista, que não poderia ter sido repetida e a questão da localização deriva das correntes que, de uma forma ou outra, sempre estiveram contra a reforma agrária, essas apegam 
a quaisquer argumentos - lógicos ou ilógicos, para eximirem as terras do raio da ação dos órgãos governamentais. A questão da localização é uma delas. Ora, é sabido que conseguir que determinada gleba se inspira no perímetro urbano, ou rural fica na dependência da boa vontade de prefeitos, muitas vezes, ligados aos proprietários de terras.

Assim, pode-se afirmar que a função social do prédio rural recai sobre propriedades tidas como rurais, que, no fundo, são agrárias por exercerem a atividade agrária e que, em decorrência desse fato, prescindem de cadastro rural, feito junto ao Instituto Nacional de Colonização e Reforma Agrária (Incra), e de pagamento de imposto territorial rural, lançado pela Secretaria da Receita Federal. Esses dois elementos integram a conceituação do imóvel rural e obrigam, por consequência, que este cumpra a função social da propriedade e, caso não atenda a esse princípio, fica passível da desapropriação para fins de reforma agrária. Muito embora, na concepção jus agrarista, o termo rural seja visto como algo estático, como já discutido (na moderna visão, é mais apropriado o termo agrário, ligado ao dinamismo), prepondera a conotação de imóvel rural na legislação, inclusive constitucional.

Nesses termos, ficam excluídos da reforma agrária os imóveis que não atendam aos requisitos supracitados: cadastro e ITR lançado, bem como aqueles imóveis que, mesmo na zona rural, não têm destinação agrária: sítios de recreio, de lazer, com finalidade turística, imóveis estes que a prefeitura local optou por considerar bens urbanos. Toda essa discussão será de suma importância quando se verificar que o imóvel rural, passível de reforma agrária, terá como meta a produção familiar, que será mecanismo para a segurança alimentar. Outrossim, somente os imóveis rurais (legislação) ou agrários (nova concepção) poderão ser cobrados para a produção de alimentos ou para qualquer atividade agrária, ou ainda para outras discussões tratadas neste trabalho.

\section{O atendimento da função social pelo imóvel rural: o elemento econômico, social e ambiental}

Ao se adentrar na questão maior do atendimento da função social pelo imóvel rural, constata-se que a simples leitura legal pouco diz, tanto no texto constitucional (art. 186), como no art. $9^{\circ}$, da Lei $n^{\circ} 8.629 / 93$. No plano 
teórico, muito embora o texto da lei infraconstitucional tenha se esmerado em criar definições claras em seus incisos, na prática inviabiliza-se o controle desse cumprimento, uma vez que o Incra, em sua vistoria, determinada em lei, emite um laudo centrado apenas na produtividade do imóvel, medindo índices de GDU (graus de utilização da terra, que devem atingir até $80 \%$ das terras economicamente aproveitáveis) e do GDE (graus de eficiência, igual ou superior a 100\%), desprezando os demais itens constantes na definição da função social. Conclui-se que, no atual momento histórico, legal e prático, a função social da propriedade do imóvel rural fica reduzida, para fins de desapropriação para reforma agrária, à análise do fator econômico, que permite fazer uma leitura (errônea) de que, num primeiro momento, a função social é atendimento à produtividade.

Percebe-se, todavia, que o esforço da lei em determinar, simultaneamente, para todos os itens dispostos no artigo 186, e em colocar e definir, nos incisos do artigo $9^{\circ}$, da Lei $\mathrm{n}^{\circ} 8.629$, como se deve fazer para atingir o cumprimento desse propósito, não surtiu o efeito desejado. Na prática, os outros elementos da função social são desprezados, mantendo-se como ícone o cumprimento da produtividade. Fala-se muito em meio ambiente, em direitos sociais, nos discursos acadêmicos e mesmo políticos, mas, estes, no momento vital de serem exigidos, são levados à bancarrota, sendo preferencialmente preteridos pelo elemento econômico da produtividade, com aval do próprio Estado.

Raízes, para tal feito, não repousam em fatos atuais ou em pressões da UDR, ou de políticos defensores dos segmentos monoculturais, ou agroindustriais do País. São fatos decorrentes de uma história jurídica intimamente vinculada ao poder do senhor de terras. O reconhecimento de tais dados para análise requer consideração deste elemento do passado, de relevância irrefutável para o Direito. Melhor para este momento é lembrar Castanheira Neves (1967, p.906) que afirma: "O Direito é essencialmente histórico. E isto porque é ele mesmo historicidade e faz história . Ele é histórico não porque seu tempo é o passado, mas porque o seu tempo é o futuro a precipitar-se e a moldar o presente".

No Brasil, há de se observar que as leis foram, e ainda o são, muitas vezes, palavras ao vento. Foi assim com diversos textos legais, e, principalmente, na área rural, o elemento econômico foi preponderante, desde a colonização. Da terra tira-se tudo; a terra deve ser explorada e não cultivada. 
A terra é meio exclusivo de se obter lucro. Os recursos da terra são inesgotáveis. O homem ganhará seu sustento com o suor do seu rosto; o escravo não tem direitos e outras tantas inverdades constituíram-se em frases-realidade e motivaram, sem dúvida, o desprezo ao homem, como ser vivente e dependente da terra, que deve ser tratada com desvelo para garantir as demais gerações.

No ensaio histórico, observa-se, no entanto, que a produtividade representa um elemento essencial, inclusive para alimentar a população, e não pode ser negado; porém, deve ser visto como meio e não como fim de poder, de dominação, e não pode ser desfrutado por um grupo seleto de pessoas.

O Brasil pouco evoluiu nesse raciocínio econômico-jurídico. A terra foi sempre da minoria, e esta sobre ela ditou as regras e impôs o seu poder. Gilberto Freyre (2003, p.38) descreve com sapiência:

A casa grande venceu, no Brasil, a igreja nos impulsionou que esta a princípio manifestou para ser a dona da terra. Vencido o jesuíta, o senhor do engenho ficou dominando a colônia quase que sozinho $\mathrm{O}$ verdadeiro dono do Brasil. A força concentrou-se nas mãos dos senhores rurais. Donos das terras. Dono dos homens. Dono das mulheres [...] O irônico, porém, é que por falta de potencial humano, toda essa solidez arrogante de forma e de material foi muitas vezes inútil, na terceira ou quarta geração [...] No fim de contas, as igrejas é que têm sobrevivido às casas-grandes.

O texto escrito, no início do século passado, descreve com precisão o poder do senhor da terra que, mesmo não sendo, em muitos casos (como na região de Ribeirão Preto, SP), proprietário, mas arrendatário, domina a política, a economia, a lei e o destino dos pobres. São esses senhores que, sob o pretexto de produzirem e de serem vitais para a economia brasileira (na verdade passam a ser, tendo em conta as políticas agrícolas adotadas), determinam como deve ser o cumprimento da lei: Produziu? Atingiu índices de produtividade? Está previsto no GDU e GDE? É o que basta! O homem que labuta nessa produtividade não importa, e o meio ambiente onde a produtividade é manifesta não tem valor. Racional e adequado é produzir, criar divisas, fazer reais tornarem-se dólares ou euros. Como afirma Freyre (2003, p.96): "A pressão monocultural é histórica e nada mais é tão perturbador para a natureza como o cultivo de uma planta só". 
A monocultura não só deteriora a natureza, como também cria a atual dispersão social do meio agrário. Imóveis rurais com grandes extensões monoculturais, como a soja, a cana e a laranja, empurram o trabalhador para uma vida miserável, destroem seus direitos sociais e desnutrem as populações locais, pois os preços desses alimentos sobem à medida que ganham altas taxas nos mercados de exportação. A título de ilustração, pode-se verificar que o Brasil, o maior produtor de soja do mundo, mantém uma cesta básica de alto custo, onde o óleo de soja está sempre oscilante no mercado internacional. Produzir mais soja não significa função social, bem-estar para população. Com certeza, representa preços mais altos do óleo desse produto na mesa do brasileiro. O mesmo acontece com o açúcar, com a carne bovina, com o frango e tantos outros produtos. Portanto, conclui-se, mais uma vez, que a política agrícola emanada da lei favorece os grandes proprietários e a balança comercial brasileira, não atingindo o cumprimento da produtividade no âmbito social. Não há que se falar que esse tipo de produtividade preserva o meio ambiente ou favorece o bem-estar dos proprietários e trabalhadores rurais; dos primeiros, com certeza, o que obviamente provoca tensão social e conflitos, não atingindo o proposto pela lei.

Ademais, em recente manifestação, o superintendente do Incra de São Paulo criticou severamente os critérios de produtividade determinados pelo órgão federal. Segundo Raimundo Silva (2004):

Os entraves dos critérios adotados na avaliação do índice de produtividade são intensos, pois estes datam da década de 70 e que os avanços tecnológicos permitem cobrar muito mais do que se exige. Conclui o procurador que as terras boas e produtivas ficam fora da reforma agrária e o que sobra para os assentamentos são áreas degradadas e pobres e o ônus da recuperação fica por conta dos assentados.

Numa visão realista, pode-se afirmar que, num futuro próximo, desses assentados serão exigidos, certamente, o GDU e GDE, e o seu não cumprimento implicará a crítica perversa sobre os assentados, que, provavelmente, serão qualificados como marginais, bandidos sórdidos e desdentados, que não querem e não possuem vocação para o trabalho rural. São esses os argumentos que a imprensa, a serviço do poder rural, usa para desmerecer a classe trabalhadora agrária que luta pelos seus direitos. 
Sob o prisma legal dos incisos sociais, é degradante ter afirmar o total desrespeito pelos direitos humanos no meio rural. Os recentes dados estimam que existam, no Brasil, 25 mil escravos, nas condições assim descritas:

Os escravos do novo milênio trabalham até 20 horas por dia sem folgas nos fins de semana, dividem a água que bebem com vacas e bezerros, moram em senzalas de lona no meio da floresta, são obrigados a pagar pelo transporte até o local de trabalho, pelas enxadas e foices que utilizam e também pelo que comem. Muitas vezes são vigiados por jagunços armados que os impedem de se movimentar livremente, têm que comprar tudo o que precisam em armazéns pertencentes ao próprio empregador que cobra preços extorsivos. O salário sempre irrisório, acaba sendo utilizado apenas para amortizar uma dívida que não para de crescer e nunca poderá ser quitada. (Reis, 2004, p.11)

Esse relato cala qualquer pretensão de dizer que, no Brasil, se atende à função social nos itens que almejam o cumprimento da legislação trabalhista e o bem-estar dos trabalhadores. Outros desatinos também são cometidos, como o trabalho degradante, a falta de atendimento aos dissídios individuais e coletivos aliada à entrada desordenada das máquinas, que retiram o trabalho de milhares de boias-frias, jogando-os à marginália. Outros tantos trabalham sem previdência, sem atendimento de saúde, sem acesso às escolas e, portanto, sem condições de sair do ciclo da miséria. Por seu turno, o governo federal não dispõe de equipamentos, fiscalização, veículos, diárias e leis duras para o combate a essa vergonha nacional. O sociólogo norte-americano Kevin Bales, citado por Francisco Reis (2004, p.12), em entrevista no Brasil, sugeriu ao governo federal algumas medidas para combater o trabalho escravo no País:

1. Formar força tarefa nacional contra a escravidão e o tráfico humano, liderada por alguém enérgico, com poder e recursos.

2. Reformar a lei para permitir, em nível federal, processar traficantes e donos de escravos.

3. Reformar a lei, de forma a permitir que a investigação "siga o dinheiro" para encontrar quem se beneficia das fazendas, minas, carvoarias, que se utilizam do trabalho escravo. 
4. Aumentar o número de equipes especiais de combate ao trabalho forçado para, pelo menos, 20 .

5. Punir severamente a corrupção policial e de funcionários públicos.

6. Deslocar recursos significativos para erradicar a escravidão e preveni-la, por meio de educação pública.

Esses remédios propostos poderão, sem dúvida, frear o trabalho escravo, bem como propiciar, em parte, a efetivação do atendimento da função social, no que estabelece o respeito ao trabalhador e à sua dignidade. No que tange à paz e à ausência de conflitos, somente uma melhor redistribuição e democratização da terra garantirá o equilíbrio social no meio rural.

Por fim, quanto ao item que abarca a questão do uso adequado dos recursos naturais disponíveis, é de se lembrar a lição de Nobre Júnior (2000, p.136):

[...] qualifica esta mensagem legislativa como sendo a exploração do proprietário, em compasso com a vocação natural da terra, com vistas a preservar o seu potencial produtivo. Acredita o autor que a busca elevada do fator de produção também não deverá ser nociva ao ecossistema. Uma boa produtividade não compensa a degradação do meio ambiente. No ditamento da Lei 8.629/93, a conservação do meio ambiente refere-se à manutenção das características próprias do meio natural e da qualidade dos recursos ambientais na medida necessária para se assegurar a continuidade do equilíbrio ecológico e da saúde da propriedade e vida das comunidades vizinhas.

Nesse diapasão, há de se compreender que o atendimento da função social, na questão ecológica, perfaz-se na certeza de que a natureza irá se firmar e corresponder aos anseios do homem quando for tratada com respeito, prudência, inteligência e previsão saudável. Ao que parece, o Brasil vem caminhando em passos ainda lentos para efetivação desse princípio. O pronunciamento de uma série de leis tratando da questão tem colaborado para a manutenção sistemática de uma luta pelo equilíbrio ecológico. As dificuldades esbarram na mentalidade pouco desenvolvida dos cidadãos, no processo de conscientização de um desenvolvimento harmônico e equilibrado de um meio rural preservado em suas origens e tendências. Vários empecilhos econômicos advindos da exploração da madeira, do uso 
de agrotóxicos, de adubos proibidos, da queimada da cana, da pulverização aérea da soja, de corte rasante de florestas, das monoculturas devassadoras, do desrespeito a áreas de preservação permanente e, talvez, da dúvida dos transgênicos são problemas ainda a serem vencidos. Todavia, os projetos de agricultura familiar organizada, as cooperativas de orgânicos e, até como lembra Ballestero Hernadez (1990, p.233), "a produção de produtos agrários limpos consumidos em restaurantes da moda contribuem para um resultado positivo para favorecer o cumprimento de uma preservação ambiental". Não descarta o autor espanhol as metas de turismo rural, que devem contar com a colaboração maior da sociedade para motivar o tombamento de áreas verdes preservadas com finalidade econômica, porém bem cuidadas e mantidas no entorno agrário ambiental, fortalecendo, dessa maneira, a preservação natural do local.

Muito mais promissoras são as oportunidades de o meio ambiente ser preservado, do que o próprio ser humano, uma vez que sobre ele recai não só uma preocupação internacional, mas também o trunfo de cuidados necessários para garantir uma boa produtividade no futuro.

Finalmente, à guisa de conclusões deste capítulo, lembramos que, à frente, nos próximos itens, serão abordados, com maior riqueza de detalhes, os tópicos referentes aos direitos humanos e ao meio ambiente, relacionados à segurança alimentar. Aqui, somente se tratou, em rápidas pinceladas, das questões social e ambiental, com o intuito de demonstrar que a função social dificilmente é cumprida no Brasil. As raízes para tal feito derivam da desigualdade social no campo, da concentração de terras e dos fatos históricos que engessaram as mudanças na condução das políticas agrárias. O texto legal é suficiente para coibir grande parte dos desacertos, porém a qualificadora da propriedade produtiva torna-se um entrave para o andamento das questões judiciais. A mentalidade da propriedade absoluta ainda é reinante na oligarquia rural. A conscientização social nas faculdades de Direito e o estudo jurídico crítico e reflexivo devem ser aguçados nos bancos acadêmico com o propósito de construir novos juristas preocupados com o Direito que faz justiça.

O item produtividade deve continuar a ser exigido, porém com a função social de produzir alimentos seguros e com acesso a todos da sociedade, e não a um só mercado exportador. Os pequenos agricultores deverão produzir com racionalidade e, para tanto, devem receber incentivos e não somente os grandes produtores, detentores de produtividade premiada. 
O item ambiental deve ser aprimorado dia a dia, partindo-se da conscientização da sociedade que deve exigir produtos de qualidade e com preços acessíveis. As áreas de preservação ambiental e as reservas devem ser exploradas com sustentabilidade, e as metas públicas devem atingir um trabalho conjunto que favoreça os programas de sucesso ambiental.

O inciso social, este sim, deve ser repensado in totum, com políticas governamentais eficazes, priorizando os anseios de democracia plena e participativa, com respeito ao cidadão e à sua dignidade. Mister é o pronunciamento de Novoa Monreal (1979, p.62):

Por meio da função social da propriedade é que as constituições e as legislações modernas tratam de resolver a questão social e alcançar uma forma de organização jurídico-institucional, que lhes permita solucionar as múltiplas contradições econômico-sociais em que vive boa parte das sociedades de hoje.

Tudo será em vão se o homem não for respeitado. O desenvolvimento só será pleno se as liberdades individuais forem garantidas em sua totalidade. As sociedades com menos desigualdades são as que tendem a crescer com mais rapidez. O atendimento à função social, previsto na Constituição de 1988, foi uma meta para o campo mudar, crescer e prosperar. Outra alternativa, contrária a essa, torna-se por demais obsoleta. Forçoso é o seu cumprimento, e a luta para tal torna-se um compromisso gravado no pensamento do jurista hodierno, compromissado com a justiça social. 


\section{2 \\ Direito Agrário e diReitos humanos}

\section{Direitos humanos: efetividade e implementação}

Quando se fala em direitos humanos, corre-se o risco de significados errôneos a respeito, tendo-se em conta a diversidade de interpretações motivadas por tal expressão. Em diferentes situações de arguição sobre a questão, a maioria das respostas evidencia deduções supérfluas, comprovando que cada ser humano tem os seus próprios direitos, descaracterizando o sentido real da expressão, que se perfaz num conjunto de atribuições que estimam tais direitos e derivam deles, com antecedentes históricos significativos e realidades sociopolíticas com significados precisos (Luño, 2003, p.22).

Para alguns autores, direitos humanos supõem uma constante histórica, cujas raízes remontam a instituições e pensamentos do mundo clássico (Lion apud Luño, 2003, p.22). Outros, ao contrário, sustentam que essa ideia de direitos humanos nasce com a afirmação cristã da dignidade moral do homem como pessoa (Bataglia apud Luño, 2003, p.23). Nesse raciocínio, encontra-se o postulado de que o cristianismo trouxe uma aceitação conformista do direito de escravatura humana, não supondo uma mensagem de liberdade apregoada pelos direitos humanos (Knoll apud Luño, 2003, p.23). Mais frequente é dizer que os direitos humanos nascem contra o regime feudal e a formação das relações burguesas (Ketchekian apud Luño, 2003, p.23). Outras tantas opiniões argumentam que os direitos humanos decorrem dos jusnaturalistas e que, portanto, são direitos naturais (Del Vecchio et al. apud Luño, 2003, p.23). De outra parte, os direitos humanos 
são definidos como produto da progressiva afirmação da individualidade, com a defesa da propriedade individual, da liberdade religiosa e da gênese do capitalismo moderno (Weber apud Luño, 2003, p.24). As controvérsias não param aí: em resposta aos direitos individuais, surge a tese dos direitos humanos com reafirmação do seu significado social (Gurvitch apud Luño, 2003, p.24). Diante de tantas indagações, conclui-se que essa expressão traz uma certeza, expressa por Bobbio (1992, p.4), como um termo não realmente definido e, quando o é, torna-se mal formulado. Para tanto, Bobbio analisou o tema "direitos humanos" em três dimensões, para assim apresentar um conceito que ele chama de razoável: uma definição tautológica que não aporta nenhum elemento novo que permita caracterizar tais direitos. Assim, os direitos do homem são os que correspondem ao homem por direito de ser homem. A definição formal não especifica o conteúdo desses direitos, limitando-se a alguma indicação sobre seu estatuto, desenhado ou proposto, como os direitos do homem são aqueles que pertencem e devem pertencer a todos os homens e dos quais ninguém pode ser privado. Por fim, Bobbio (1992, p.5) atribui uma definição teleológica, na qual apela a certos valores últimos, suscetíveis de diversas interpretações como: os direitos do homem são aqueles imprescindíveis para o aperfeiçoamento da pessoa humana, para o progresso social e para o desenvolvimento da civilização.

Embora seja vaga e imprecisa a discussão de progresso e desenvolvimento, não é possível pensar e elaborar uma noção de direitos humanos com limites significativos com base no exposto. Mas, diante de uma ideologia e de uma postura sociopolítica, pode-se iniciar a construção de um conceito amplo que terá limites internos e externos, os quais contracenarão com os direitos naturais, os direitos fundamentais, os direitos subjetivos, os direitos públicos subjetivos, os direitos individuais e as liberdades públicas. As dimensões estarão, em nível interno, determinadas na legislação pátria e, ainda, pelas questões externas, com controle supranacional.

A expressão "direitos humanos" altera-se de acordo com a realidade e a experiência de cada povo. Na doutrina tradicional, tem-se uma clara noção de que os direitos humanos constituem a conjunção dos direitos naturais, ou seja, correspondem ao homem pelo mero direito de existir e que os direitos civis são aqueles que correspondem ao homem, pelo direito de ser membro da sociedade (Paine, 1944, p.61). À luz dos direitos fundamentais, após 1770, na França, passa-se a adotar o posicionamento de que os direitos 
fundamentais são aqueles direitos humanos positivados nas constituições estatais e, ainda, seriam aqueles princípios que resumem a concepção do mundo e que informam a ideologia política de cada ordenamento jurídico. Haberle (apud Luño, 2003, p.31) contribui, considerando os direitos fundamentais como a síntese das garantias individuais, contidas na tradição dos direitos políticos subjetivos e das exigências sociais, derivadas da concepção institucional do direito. Dessa forma, pode-se afirmar, embora não de maneira unânime, uma certa tendência em chamar de direitos fundamentais os direitos humanos positivados, em nível interno. Já se emprega a expressão "direitos humanos" no plano das declarações e convenções internacionais, para expressar esses mesmos direitos fundamentais na linguagem mundial.

Jorge Miranda (1988, p.48) anota que a locução "direitos fundamentais" tem sido a preferida na doutrina e nos textos constitucionais, para designar os direitos das pessoas em face do Estado, disciplinados na Constituição. Conquanto já empregada no século XIX, a expressão remonta principalmente à Constituição de Weimar, cuja parte dois versava sobre direitos e deveres fundamentais dos alemães, encontrando-se hoje generalizada, sendo usada pelas constituições de praticamente todos os países. O autor em pauta recomenda que a locução "direitos do homem" deve ser evitada, dando total preferência à expressão "direitos fundamentais", e justifica:

[...] ao jurista cabe analisar não o fundamento dos direitos, mas o direito em si, tal como positivados na ordem jurídica; segundo, porque os direitos fundamentais não podem ser desprendidos da organização econômica, social, cultural e política; terceiro, porque nas Constituições do séc. XX há direitos conferidos a instituições, grupos ou pessoas coletivas: direitos das famílias, das associações, dos sindicatos, dos partidos, os quais não são direitos impostos pelo Direito natural.

Direitos fundamentais, para Sarlet (2001, p.31-7), são aqueles direitos do ser humano reconhecidos e positivados na esfera do direito constitucional positivo de determinado Estado, ao passo que os direitos humanos são os direitos reconhecidos nos documentos de direito internacional, tendo validade universal para todos os povos e tempos, de tal sorte que revelam um inequívoco caráter supranacional (internacional). 
José Afonso da Silva (2006, p.27) assevera que "direitos fundamentais" é a expressão correta, porque o qualificativo "fundamentais" expressa situações jurídicas sem as quais a pessoa humana não se realiza, não convive $\mathrm{e}$, às vezes, nem mesmo sobrevive. São fundamentais os direitos humanos no sentido de que todos, por igual, devem ser, não apenas formalmente reconhecidos, mas concreta e materialmente efetivados.

Os que entendem os direitos humanos se interligando aos direitos subjetivos encontram dificuldades a partir da própria imprecisão dessa figura. Em um significado técnico jurídico positivo, os direitos subjetivos não se identificam com os direitos humanos, trazem em comum algumas regras de inalienabilidade e imprescritibilidade. O que acontece é uma confusão, pois, na maioria das vezes, contemplam-se direitos de personalidade que são similares aos direitos humanos, mas não sendo estes. Ademais, há de se lembrar, em uma visão marxista, de que os direitos subjetivos são construções do pensamento jurídico burguês, como a defesa da propriedade privada, mas que simultaneamente foram consagradas como um direito humano. Desse modo, pode-se afirmar que há coincidências e repulsas entre direitos subjetivos e direitos humanos.

Os direitos públicos subjetivos surgiram de uma decisão de situar a teoria dos direitos humanos num marco estritamente positivo, à margem de qualquer contaminação ideológica jusnaturalista. Dessa forma, fez-se que os direitos públicos subjetivos fossem vinculados a uma categoria histórica adaptada ao funcionamento de um determinado tipo de Estado, o liberal, e a uma das condições materiais que tenham sido superadas pelo desenvolvimento econômico social de nosso tempo. Políticas públicas devem limitar os abusos do setor privado e promover o desenvolvimento, o que leva ao pensamento de uma noção de direitos públicos subjetivos, como autolimitação do poder soberano do Estado, que pode ser chamada de direitos fundamentais, entendidos também como limitação que a soberania popular impõe aos órgãos que dependem dela. Portanto, a política pública deverá ser ativamente jurídica e econômica, a fim de cumprir as metas de direitos humanos, em consonância com os direitos públicos subjetivos, o que, na maioria dos casos, não acontece. Ver-se-á, adiante, a meta de observar os direitos humanos à alimentação por meio de políticas públicas.

Os direitos individuais foram usados como sinônimos de direitos humanos quando estes foram entendidos como reconhecimento de determinadas 
liberdades conectadas à autonomia dos indivíduos. Hoje, isso não é mais possível, uma vez que as exigências sociais têm maior dimensão que a individualidade do homem. As liberdades públicas são poderes de autodeterminação, reconhecidos pelo direito positivo, o que não faz coincidir com os direitos humanos, vez que estes nem sempre estão positivados.

Na busca de uma definição para os direitos humanos, com base nas considerações propostas, pode-se citar Perez Luño (2003, p.48), para quem

[...] os direitos humanos aparecem como um conjunto de faculdades e instituições que em cada momento histórico concertam as exigências da dignidade, da liberdade e da igualdade humana, as quais devem ser reconhecidas positivamente pelos ordenamentos jurídicos em nível nacional e internacional.

Permite-se objetivar os direitos humanos como uma faculdade que corresponde às necessidades humanas nos fatos históricos, para situar as necessidades que se alteram ao longo do tempo, pois os direitos alteram-se num caráter dinâmico e real (efeito tautológico) e, ao mesmo tempo, precisam apelar para valores de dignidade, liberdade e igualdade por entenderem, nessa proposta, as definições teológicas. A dignidade humana é o ponto de referência de todas as faculdades que se dirigem ao reconhecimento e à afirmação da dimensão moral da pessoa. Sua importância é a gênese da moderna teoria dos direitos humanos. ${ }^{1} \mathrm{~A}$ liberdade constitui o princípio aglutinante da luta dos direitos humanos. Essa noção identificou-se, por muito tempo, com a própria noção de direitos humanos. A igualdade é o postulado fundamental de toda moderna construção teórica e jurídica positiva dos povos. Por fim, a positivação do conjunto dessas faculdades incorre no enfoque formalista de se efetivarem, por meio de instrumentos normativos, as técnicas de proteção e garantia.

Num processo evolutivo, a origem dos direitos humanos se dá com os direitos individuais no Egito e na Mesopotâmia. Na Grécia, há o ideal de emancipação do homem cidadão, surgindo, como lembra Alexandre de Moraes (2005, p.24), estudos sobre a liberdade e igualdade do homem, como as previsões de participação política dos cidadãos e crença num di-

1 Perez Luño (2003) coloca a dignidade humana como centro dos direitos humanos, fundamentando-se em Samuel Pufendorf (inspirador das declarações americanas) e Welzel. 
reito natural superior e anterior às leis escritas. $\mathrm{O}$ cristianismo, segundo Ângela Aparisi (2006, p.167-8), desenvolveu e universalizou a ideia judaica do homem criado à imagem e semelhança de Deus, e, por isso, mais tarde, Santo Tomás de Aquino, em sua Summa theologica, no século XIII, já afirmava que o homem não pode ser rebaixado a nenhuma outra condição, pois foi reconhecido a todo ser humano um valor radical e distinto do atribuído ao restante dos seres da criação. Porém, foi o direito romano, com a Lei das XII Tábuas, que iniciou um procedimento escrito sobre liberdade, propriedade e proteção dos direitos do cidadão.

A Magna Carta constitui um marco, em que o governo é algo mais que o domínio arbitrário de qualquer homem e que a lei e o costume deveriam estar acima do próprio rei. Na Idade Média, consagra-se a ideia de que os direitos humanos têm sempre o mesmo traço: a limitação do poder estatal que, segundo Fábio Konder Comparato (2003, p.40), desde os séculos XI e X a.C até os dias de hoje, são marcas que acompanham pari passu esses direitos.

Bem mais tarde, vieram as declarações dos direitos do homem, adotadas nos Estados Unidos, em 1776, e na França, a partir da Revolução de 1789. Outros documentos que corroboraram a efetivação desses direitos foram a Petition of Right, de 1628, que previa a não obrigatoriedade do pagamento de impostos ou taxas que não tivessem o consentimento do parlamento; o Habeas Corpus, de 1679; a Bill of Rights, que restringiu o poder estatal, fortalecendo o princípio da legalidade; o direito de petição, vedação de penas cruéis, entre outras; o Act of Seattlement, de 1701, que reafirmou o princípio da legalidade e a responsabilização política dos agentes públicos.

Nos Estados Unidos, foram consagrados documentos históricos de suma importância, como a Declaração dos Direitos da Virgínia (1776), Declaração de Independência dos Estados Unidos da América (1776) e a Constituição dos Estados Unidos da América (1787).

A consagração mundial veio com a Declaração dos Direitos do Homem e do Cidadão, com 17 artigos, entre os quais se destacam algumas previsões, lembradas por Moraes (2005, p.28):

Princípio da igualdade, liberdade, propriedade, segurança, resistência à opressão, associação política, princípio da legalidade, princípio da reserva legal e anterioridade em matéria penal principio da presunção de inocência, liberdade religiosa e livre manifestação de pensamento. 
Há de se ressaltar o momento político em que nasce a Declaração dos Direitos do Homem. Para Oliveira \& Guimarães (2004, p.64), houve, na verdade, uma reação a uma ordem constituída, em que o homem passa a ser senhor de direitos, numa concepção individualista, e a burguesia foi beneficiada, com a intervenção mínima do Estado. Aponta Comparato (2003, p.49) que essa declaração é o registro de nascimento dos direitos humanos na História, representando o ato inaugural da democracia moderna, chamada de liberal e exercida por meio de representantes. Foi, na opinião desse autor, uma fórmula política encontrada pela burguesia para dar cobro aos antigos privilégios dos dois principais estamentos do Ancien Régime-o clero e a nobreza -, proclamando apenas os direitos de liberdade, sobretudo de opinião e crença, e de igualdade formal perante a lei, não contemplando direitos que visassem suplantar as grandes desigualdades sociais.

A Revolução Industrial provocou a reação dos trabalhadores, que se organizaram pelos seus direitos sociais, econômicos e culturais, os quais passaram a ser postulados, constituindo o desenvolvimento dos movimentos operários, reforçando a luta pelos direitos humanos.

As constituições espanhola, portuguesa e belga e a Declaração francesa de 1848 previram a constitucionalização dos direitos humanos, denominando-os de direitos fundamentais, que passaram a ser definitivos no século XX.

A Primeira Guerra Mundial instaurou o primado da sociedade sobre o Estado e sobre o indivíduo. O homem, pessoa, passou a ser o destinatário das normas consagradoras dos direitos fundamentais. Os direitos sociais ganharam status constitucional após a Primeira Grande Guerra, mas o reconhecimento desses direitos não foi sinônimo de sua efetivação, porque cabia ao Estado efetivá-los, o que difere dos direitos de liberdade que surgem como reação do poder supraestatal. Outra colaboração de grande valia para a formação dos direitos humanos foi a Declaração Soviética dos Direitos do Povo Trabalhador e Explorado, de 1918, lei fundamental soviética que trouxe considerações a favor da igualdade, mas que, em certos trechos, contraditou os princípios humanos, a favor do poder da revolução socialista.

Medeiros \& Guimarães (2004, p.67) afirmam que a falta de capacidade dos Estados de efetivar tais direitos gerou o caos que levou a comunidade mundial a uma Segunda Guerra Mundial, a um maior interesse das grandes correntes filosóficas, ideológicas e políticas pelos direitos fundamentais. Após a Segunda Guerra Mundial, o interesse pelos direitos fundamentais 
cresceu vertiginosamente, em decorrência das crueldades do nazismo. Foi assinada, em 10 de dezembro de 1948, a Declaração dos Direitos do Homem, havendo, a partir daí, uma multiplicação dos direitos fundamentais na segunda metade do século XX. Como consequência, passou-se a classificar os direitos humanos em três gerações, instalando-se, assim, os direitos humanos da época contemporânea, conforme alinhavados a seguir.

- Primeira geração: direitos civis e políticos que compreendem as liberdades clássicas, negativas ou formais, e realçam o princípio da liberdade e os direitos do cidadão. Paulo Bonavides (2006, p.564) considera que essa primeira geração de direitos valoriza, primeiramente, o homem singular, o homem das liberdades abstratas, o homem da sociedade mecanicista, que compõe a chamada sociedade civil, da linguagem jurídica mais usual, não tendo, dessa forma, preocupação com os problemas sociais, até porque a igualdade burguesa era exclusivamente formal.

- Segunda geração: direitos econômicos, sociais e culturais que se identificam com as liberdades positivas reais ou concretas e acentuam o princípio da igualdade. Esses direitos surgem em decorrência da deplorável situação da população pobre das cidades industrializadas da Europa ocidental, que era constituída basicamente por trabalhadores expulsos do campo (Weis, 1999, p.38-9). De acordo com Marx (1984, p.262-75), os camponeses expulsos do campo tornaram-se, muitas vezes, mendigos nas cidades. ${ }^{2}$ Wolkmer (2005, p.142-3) afirma que a ideia dos direitos humanos é vinculada a um discurso político, criticado por Marx que via nessa construção os interesses de uma burguesia individualista do século XVIII, propiciando subsídios para uma práxis que levava à superação das contradições entre os direitos do homem burguês (sociedade civil) e os direitos do cidadão abstrato (Estado Político). Como Manuel Altienza (apud Wolkmer, 2005, p.143) comenta, "é a busca da emancipação humana, que já não representa especificamente o Estado político ou, tampouco, os direitos humanos como expressão ideológica de interesses particulares".

2 Marx, nessa obra, descreve as razões de tal fato, considerando que o abandono do campo foi a vitória para a agricultura capitalista, criando para a indústria urbana a oferta necessária de um proletariado livre como os pássaros. 
Conclui Wolkmer (2005, p.143) que, quando se proclamaram os direitos humanos como emancipação política, realizou-se apenas uma etapa da dinâmica histórica. Ao longo dos anos, os direitos sociais foram se consolidando em direito ao trabalho, à saúde, à educação e à previdência social, direitos estes que exigem uma atividade positiva do Estado por meio de políticas públicas.

- Terceira geração: materializa poderes de titularidade coletiva, atribuídos genericamente a todas as formações sociais, e consagra o princípio da solidariedade ou fraternidade. Desenvolve o estudo dos direitos humanos como os mais consolidados e representativos, como o direito à paz, à qualidade de vida (meio ambiente) e à liberdade de informática. Perez Luño (2006, p.15) assinala que os direitos e as liberdades da terceira geração se apresentam como uma resposta ao fenômeno da denominada "contaminação das liberdades". O autor acentua que a revolução tecnológica redimensionou as relações entre os seres humanos, entre o homem e a natureza, e do ser humano com o seu contexto ou marco cultural de convivência, já que essas mudanças claramente incidem na esfera dos direitos humanos.

Ainda sob o ponto de vista das gerações dos direitos humanos, o assunto não é pacífico. Celso Lafer (1988, p.127) considera que os direitos humanos devem ser elencados em quatro gerações e que os últimos recaem nos grupos primários e nas grandes formações sociais.

Cançado Trindade (1993, p.191-32) contraria a tese das gerações, não se considerando adepto a essa proposta; de acordo com o seu ponto de vista, essa tese é fragmentadora, tomando os direitos de forma dividida, não correspondendo à realidade. Segundo o autor, essa evolução deu-se no plano dos direitos internos, e, no âmbito internacional, a evolução foi contrária, ou seja, os direitos que primeiro surgiram foram os econômicos e sociais. A sequência correta seria: em primeiro lugar, os direitos ao trabalho e condições de trabalho; em segundo, os direitos individuais, com a Declaração Universal dos Direitos Humanos e a americana, de 1948. A terminologia "gerações" leva ao raciocínio de seres humanos que se sucedem no tempo, não à ideia de somatização dos direitos anteriores aos posteriores. Afirma que os novos direitos - os direitos de solidariedade, como o direito ao desenvolvimento e ao meio ambiente sadio - interagem com os direitos indi- 
viduais e sociais, não os substituindo, distintamente do que a noção simplista das chamadas gerações de direitos humanos pretenderia ou pareceria insinuar. Se, por um lado, os seres humanos se sucedem no tempo, os direitos, por outro, se acumulam e se sedimentam. Pondera, finalmente, o autor que, nem mesmo para fins didáticos, essa concepção deve ser utilizada, pois os riscos dessa visão atomizada dos direitos humanos são manifestos.

Bonavides (2006, p. 571-2) admite o equívoco do termo "geração" e preconiza que haja uma substituição por "dimensão", que possuí vantagem lógica e qualitativa em relação àquele.

Por certo, deve-se considerar que as ideologias exprimem posturas que se convergem para a fixação desses direitos humanos, em grau superior de efetivação e com o intento de colocá-los em marco positivo nas constituições, a fim de que fossem aplicados e cobrados num compromisso do Estado com o povo e o mundo.

Se em gerações ou não, é pacífico que os direitos fundamentais se classificam em individuais, econômicos, sociais e de solidariedade. Compartilha-se então, nesse ponto, da posição de Cançado Trindade (1993) de que os direitos se interligam e se complementam, e, na vinculação do tema do trabalho aqui proposto - Direito Agrário e segurança alimentar - os direitos humanos são corolários imprescindíveis, pois, por meio deles, firmam-se os direitos à vida, à saúde, à alimentação adequada, que só se consolidam a partir do momento em que o homem tem direito ao trabalho digno, à paz e a um meio ambiente saudável. Direitos humanos vinculam-se a todos os ramos jurídicos, em especial aos referentes ao tema objeto da pesquisa. Sem alimento, não há vida; sem trabalho, não há acesso à dignidade, não se têm direitos plenos; sem democracia, não há liberdades, não há igualdades; portanto, o entrelaçamento dos temas é mister para que se efetive o papel dos Estados via políticas públicas.

Com base nessas propostas, verifica-se, então, a estreita interação entre os direitos humanos e o Direito Agrário, no que concerne ao direito à vida (produção de alimentos), ao trabalho-dignidade no meio rural, ao meio ambiente (os bens naturais estão concentrados no meio rural) e, por fim, às questões sociais plenas, que encaminham para paz e para a solidariedade entre os povos.

No Brasil, os direitos humanos ganharam nova expressão, a partir de 1988, com a Constituição Federal. O artigo $5^{\circ}$ descreve os direitos e as ga- 
rantias individuais, com exatidão e presteza de Primeiro Mundo. Mas não é só: o meio ambiente, a política dos direitos sociais, a política econômica, os direitos do consumidor, a lei tributária e fiscal, a função social estão presentes em diferentes capítulos da Carta Magna. Num primeiro olhar, a ideologia e o positivismo aqui propostos revelam a expressão de um país consolidado em princípios democráticos que respeitam e implantam a dignidade do cidadão, ao menos em seu teor legal.

Quando se fixam os olhos na realidade, encontram-se, entretanto, violações aos direitos humanos, nos mais diferentes setores. Revela-se uma postura característica dos países latinos que tiveram sua história calcada, no dizer de Wolkmer (2004, p.2), na dominação interna e na submissão externa. Trata-se de uma cultura montada a partir da lógica da colonização, exploração, dominação e exclusão dos múltiplos segmentos étnicos, religiosos e comunitários. Uma história de contradições marcada pelo autoritarismo e pela violência de minorias, pela marginalidade e resistência das maiorias ausentes da história, como os movimentos indígenas, negros, campesinos e populares. O fracasso nos direitos humanos também se dá pela formação corrupta dos políticos, dos governos ditatoriais, dos governos pseudodemocráticos, que caminharam com leis avançadas, mas que nunca foram aplicadas.

As violações aos direitos humanos, no Brasil, decorrem do não cumprimento das determinações que integram a atual Constituição; decorrem da ausência das políticas públicas, do desrespeito ao cidadão, da miséria do povo, da exploração econômica, da corrupção dos políticos e do próprio desrespeito entre os membros da sociedade. Obviamente, não se espera a integralização plena dos direitos humanos, mas o papel do Direito e da Justiça deve ser de luta efetiva, em todos os setores, indiscriminadamente, para que esses direitos sejam garantidos, e qualquer violação deve ser denunciada não só pelas autoridades competentes, mas também pela sociedade organizada, que deve pedir medidas cabíveis ou buscar, nacional ou internacionalmente, soluções perante os órgãos competentes.

O meio rural, por sua vez, torna-se o maior centro de violações aos direitos humanos, pelas dificuldades que reinam em seu interior: trabalho escravo, trabalho infantil, trabalho degradante, fome, analfabetismo, mortalidade infantil, desemprego, concentração fundiária, mortes em conflitos agrários sem providências jurídicas, ausência de reforma agrária consisten- 
te, falta de saneamento básico e infraestrutura viária, e todos os danos ambientais cometidos, que se refletem no tráfico de madeira, na derrubada de florestas, na poluição das águas e nos danos biológicos irreversíveis à fauna e à flora, com o agravante de as denúncias, nesse setor, serem de mais difícil efetividade.

A situação agrária clama por políticas emergenciais. Nesse setor, as responsabilidades advindas dessas violações agravam a situação do campo dia a dia, formando um ciclo vicioso sem perspectivas. A título de exemplo, pode-se citar que a ausência do cumprimento das normas de vacinação do gado e a falta de vigilância por parte dos organismos públicos provocaram a derrocada na venda de carnes, o que, simultaneamente, resultou na queda dos rendimentos rurais que desencadeou o desemprego, o agravamento da fome, a falta de perspectiva na terra, a migração para os grandes centros onde se agravam a violência, a poluição, a destruição ambiental e o desordenamento urbano. Por um único ato, o caos instala-se.

São muitos os casos divulgados pela mídia que, mesmo sob o viés muitas vezes - das empresas privadas, cumpre seu papel democrático de denunciar e apontar a ausência de democracia e responsabilidade pública e social dos diferentes setores. O poder econômico da mídia, no dizer de Emir Sater (2001, p.63), é a principal via de socialização de informações para leitores, ouvintes e telespectadores, ao mesmo tempo que lhes oferece um espaço de discussão. As denúncias convertem-se nos relatos, tais como a falta de vigilância na Amazônia, que repercute em sua destruição e em sua biodiversidade; a intimidação dos fiscais do Trabalho, provocando mortes e mantendo a vergonha do trabalho escravo (ver o caso em Minas Gerais); denúncias de trabalho infantil no sisal, na cana, na carvoaria; o plantio de transgênicos sem as devidas precauções; os altos índices de desnutrição; o tráfico ilegal de madeiras; o desvio de verbas destinadas aos programas de erradicação da fome; e tantos outros casos que serão apresentados nas discussões que seguem.

No âmbito internacional, é comum assistir ao Brasil sendo punido por organismos de defesa dos direitos humanos. As sanções são de caráter econômico e agravam os setores de baixa renda. Essas medidas também precisam ser revistas, uma vez que atingem sempre o segmento mais sofrido.

Portanto, da previsão constitucional à realidade nacional, existe um profundo abismo que precisa ser vencido. Os direitos humanos tornaram-se 
direitos fundamentais, mas isso não significou sua efetivação. $O$ foco deste trabalho é o meio rural, manchado pelo sangue das violações múltiplas aos direitos humanos. Esse setor acumula traições, sofrimento, injustiças e abandono, e, simultaneamente, oferece a quem nele se vive alimento, recursos naturais, oportunidades de trabalho e perspectiva de efetivação de direitos de paz e solidariedade. Um paradoxo que precisa ser pensado pelo Estado e pela sociedade como um todo.

\section{Direitos humanos e Direito Agrário}

Numa linha de pensamento firmada no estudo de Zeledon y Zeledon (2002, p.21), os direitos humanos e o Direito Agrário têm uma série de elementos comuns, cuja racionalização e desenvolvimento científico permitem encontrar coincidências para superação dos limites com os quais eles têm que conviver, sem descaracterizar a verdadeira personalidade de cada um, que são, em comum, a efetivação da justiça social. A valorização do trabalho humano, a preservação da dignidade e o oferecimento de solidariedade encontram-se em ambas as disciplinas. Isso traduz que os direitos humanos de desenvolvimento, paz, direito ao patrimônio comum da humanidade, assim como os civis e políticos e os econômicos, sociais e culturais, saltam aos olhos quando o tema é Direito Agrário. Existe uma internacionalização dos direitos humanos, e, hoje, também isso é vislumbrado no Direito Agrário. A Declaração sobre Direito ao Desenvolvimento, de 1986, deixa claro que todos os povos devem participar do desenvolvimento no âmbito econômico, social, cultural e político, assim como todos devem ter a plena realização dos direitos humanos e das liberdades fundamentais. Para tanto, os Estados devem firmar políticas para melhorar a vida da população, com distribuição equitativa dos resultados obtidos em sua economia. Os Estados devem estabelecer planos de cooperação entre eles, na proporção de suas riquezas, evitando a miséria a fome, e os abusos dos ricos. De sua parte, o Direito Agrário deve estabelecer legislações que conduzam à harmonia entre os direitos individuais e econômicos, sociais e os de terceira geração. Essa nova filosofia sustentável deve aspirar a um Direito Agrário para enfrentar as realidades, vinculado ao desenvolvimento econômico, voltado para a efetivação dos direitos humanos, em todos os seus setores. 
Assim, quando se pensa na elaboração de um contrato, deve-se estabelecer o equilíbrio das partes; quando se tem uma propriedade, esta deve estar resguardada, porém seus contornos são estabelecidos em uma norma que prevê a função social dessa propriedade: um crédito rural deve existir com oportunidade igual para todos; uma desapropriação terá de ser realizada nos limites legais, se provada a necessidade de seu uso para o interesse público. Portanto, a previsão legal deve estar em harmonia com os direitos fundamentais, mas deve também atender aos objetivos do Estado, e este, por sua vez, deve estabelecer políticas não para as minorias, mas para atender ao interesse público que, quase sempre, não coincide com a minoria, de alto poder econômico.

A atividade agrária, já demonstrada ao longo do texto, reúne interesses sociais e públicos em todas as suas ramas e constitui o maior interesse da nação (ou, ao menos, deveria constituir).

O empresário agrário reúne uma gama de produção que desencadeia na transformação, na industrialização, na comercialização de bens com o objetivo de lograr um aumento de produtividade como atividade economicamente organizada, buscando um tratamento mais justo para todos os sujeitos interligados na produção agrária. Esse é o suporte mais importante da sociedade no solo, no âmbito alimentar, em muitos outros destinados a assumir tanto o risco típico do mercado como da natureza. (Zeledon y Zeledon, 2002, p.39)

Em concordância com Zeledon y Zeledon (2002), cumpre apenas acrescer que empresário é todo aquele que produz sem diferenças econômicas e que, na elaboração da produção agrária, subsiste o elemento natureza. A opção por modelos econômicos orgânicos, tradicionais, biológicos ou por meio de novas técnicas, como os transgênicos, tramita em paralelo com a questão ambiental que, como já foi afirmado, resulta na proteção, ou não, do meio ambiente. Também as técnicas e os modelos recaem na manutenção, ou não, das tradições culturais de uma comunidade, no costume local, na repercussão da migração que desencadeia no acúmulo de pessoas nas cidades, ferindo a lógica do meio urbano.

Não necessariamente a implicação de direitos humanos agrários (se é que se pode resumir, dessa forma, essa junção) resulta no abandono de técnicas modernas de desenvolvimento econômico e de impedimento do cres- 
cimento dos setores agroindustriais e agrocomerciais. Não seria cabível - e nem existiria justiça social - sem o desenvolvimento econômico. Portanto, conforme Zeledon y Zeledon (2002, p.41), isso se torna visível quando se opta por reformas agrárias, em que se distribuem pobreza e falsas esperanças. Estes são os casos típicos em que a reforma agrária se fixa somente em distribuição de terras, sem os instrumentos necessários para encontrar alternativas econômicas.

Destarte, justiça social coincide com desenvolvimento econômico. E desenvolvimento econômico, no meio agrário, clama por respeito, dignidade, cidadania e meio ambiente saudável. Muitas vezes, as respostas políticas apenas camuflam soluções.

Leis e mais leis não resolvem a questão social, pois muitas delas não saem do papel, ou são inviáveis de ser cumpridas, por falta ou má distribuição dos recursos orçamentários. As políticas públicas são responsáveis por grande parte de seu sucesso, ou não; são as chamadas funções objetivas sociais que recaem sobre o solo, sobre a incorporação do sujeito, nas políticas de manutenção da organização da atividade agrária. A função social subjetiva é a que recai sobre o proprietário que deve contribuir permanentemente para o melhoramento de sua terra, atingindo índices de produtividade, respeitando a natureza, acatando as técnicas de cultivo, melhorando as espécies, evitando as doenças de origem animal e vegetal, e respeitando o trabalho dos que lhe servem, valorando sua condição humana.

Por muito assunto, poder-se-ia estender a questão a grandes e calorosos debates se realmente fosse esse o caminho para aplicar os direitos humanos em consonância com o Direito Agrário. Tudo dependeria da realidade local, dos fatores históricos, dos clamores e das necessidades de cada povo. Com certeza, as políticas agrárias devem ser conduzidas para a efetivação do progresso econômico, social e ambiental, mas os métodos escolhidos são variáveis, diante das situações que lhe são apresentadas, envolvendo os mais diferentes ramos jurídicos, desde o tributo, a criminalização, as normas trabalhistas, o acesso à terra e as políticas agrícolas de apoio.

Em que pese a concordância, em grande parte, com a teoria humanista de Zeledon y Zeledon (2002, p.42 ss.), opta-se por trazer a lume o peso maior dos direitos humanos e do Direito Agrário, no sentido do respeito ao indivíduo em sua formação de cidadania e participação no progresso econômico e na escolha dos modelos para seu crescimento, e não apenas centrar a 
preocupação nos direitos econômicos e sociais. A visão é conjunta. $\mathrm{O}$ cidadão come? Come o quê? De onde vem seu alimento? Qual é a sua qualidade? Foi comprado à custa de seu trabalho degradante? O cidadão trabalha com dignidade? Recebe todos os seus direitos? A atividade agrária é desenvolvida? Beneficia a quem? A concorrência é moldada na lei ou se caracteriza como cartel? Os contratos estabelecidos são de adesão e abusivos? $\mathrm{O}$ alimento é fruto da destruição de um sistema ambiental? Múltiplas são as perguntas, e as respostas, as mais variadas. A gama de relações estabelecidas pelo meio agrário percorre uma trilha de direitos humanos de primeira, segunda e terceira gerações, que não se desvinculam, mas interligam-se, como um processo evolutivo de caráter mundial.

A concretização dos direitos humanos, no todo ou na questão agrária, tem de enfrentar duas perspectivas distintas que não se excluem entre si: a concretização pelo Estado e pela sociedade. José Luis Bolzan de Morais (2002) compartilha desse pensamento esclarecendo que o ente público se manifesta em nível legislativo expresso, ou implícito, por meio de uma cláusula constitucional aberta ou mesmo de valores decorrentes. Integra o caráter prestacional: a implementação dos direitos sociais, econômicos e culturais por meio da ação política - políticas públicas - estatal. Conforme Bolzan (2002, p.73-7), a concretização dos direitos humanos se manifesta pelo prisma da jurisdição, que deve utilizar, sobremaneira, os instrumentos procedimentais para fazer valer seus conteúdos, apropriando-nos do que o próprio texto constitucional coloca à disposição dos cidadãos. Assim, devem-se utilizar o habeas corpus, o habeas data e o mandado de segurança para situações individuais; para casos de violações coletivas, o mandado de segurança coletivo; e no caso de situações de direitos difusos, a ação popular e a ação civil pública, além de considerar o mandado de injunção e a ação direta de inconstitucionalidade por omissão. Na concretização pela sociedade, os direitos humanos devem ser vistos em uma perspectiva social com pretensões dirigidas à autoridade pública estadual e, ainda, pela via do comprometimento coletivo, pelo bem-estar comum, desde a assunção de tarefas sociais, no próprio âmbito da sociedade, e pelos atores sociais.

Dessa feita, há de se pensar num Direito Agrário humanístico, lembrando que os elementos fundamentais para essa análise não podem ser traçados de forma isolada, há de haver preocupação mundial; os Estados devem investir substancialmente no setor agrário. As pessoas têm de se conscientizar 
da importância da terra, para a manutenção de sua vida atual e da preservação do planeta hoje e para as gerações futuras. Essa preocupação há que se dar em nível universal, trabalhada internamente em cada Estado, na consciência de cada cidadão, no respeito a uma sociedade justa, sem fome, sem miséria e em paz.

\section{O Direito Agrário brasileiro e sua posição diante dos direitos humanos}

O Direito Agrário brasileiro ainda é deficitário em idade e funcionamento. Seus institutos, ao longo desses quarentas anos, dos quais o Estatuto da Terra é o marco inicial, são traduzidos em política fundiária (incipiente) e política agrícola incapaz de ser oferecida a todos. Assim, delimita-se estudar os direitos humanos no setor rural sob os aspectos de sua desumanização, a partir das violações ambientais, da desumanização trabalhista, da concentração de terras e, sobremaneira, sob a ótica da insustentabilidade da atividade agrária como instrumento da segurança alimentar democrática.

Em que pesem os esforços de origem interna e de agenda internacional para a consagração dos direitos humanos, a partir de 1985, as violações no meio rural são, sobremodo, as mais deflagradas. Também a consequência da migração rural para as periferias das cidades contribui para degradação da cidadania urbana. Os instrumentos jurídicos da Constituição brasileira são suficientes no plano legal. As legislações infraconstitucionais, no âmbito penal, ambiental, agrário, consumerista, trabalhista, de proteção à infância e à juventude, da função social da propriedade, dos contratos e da empresa, são algumas manifestações de cunho legal que justificam a preocupação do Estado em proteger as pessoas e a sociedade em geral. No universo do Direito Agrário, os institutos jurídicos (elemento econômico, ambiental e social) nada mais são que os elementos constituintes da função social da propriedade, princípio-mor do Direito Agrário.

Flávia Piovezan (2006, p.256) ressalta a importância dos direitos humanos no âmbito internacional:

Com efeito, ao longo do processo de democratização, o Brasil passou a aderir a importantes instrumentos internacionais de direitos humanos, aceitando 
expressamente a legitimidade das preocupações internacionais e dispondo-se a um diálogo com as instâncias internacionais sobre o cumprimento conferido pelo País às obrigações internacionais assumidas. No processo de democratização, por outro lado, acentua-se a participação e mobilização da sociedade civil e de organizações não governamentais no debate sobre a proteção dos direitos humanos.

Nesse cenário, os direitos humanos vão ganhando relevância pelo processo de internacionalização, e os Estados vão tendo que incluir em suas agendas o seu cumprimento. Para Celso Lafer (1994, p.XXVI), "somente a garantia efetiva dos direitos humanos da população confere legitimidade plena aos governantes no plano mundial".

O efeito dessa globalização dos direitos humanos reflete-se na seara agrária, pois os tratados internacionais, firmados pelo Brasil, ao menos no que diga respeito às políticas públicas que caminhem para que esses direitos, serão cobrados e denunciados no plano internacional. A título de ilustração, há de se falar que são muitos os casos contra o Estado brasileiro perante a Comissão Interamericana de Direitos Humanos, cujo objetivo é examinar comunicações e petições individuais que denunciem violação a direito internacionalmente assegurado. Dos 78 casos coletados, 13 envolvem situações de violência rural, cujo teor são assassinatos de trabalhadores rurais e interceptações e monitoramentos ilegais de linhas telefônicas do MST. Nesses casos, estão arrolados o massacre de Corumbiara, Eldorado de Carajás, e os assassinatos de sindicalistas em defesa dos direitos humanos.

A propósito desses casos, Paulo Sérgio Pinheiro (apud Piovezan, 2006, p.311) lembrou que o Brasil é campeão mundial de desigualdade, que a renda dos $20 \%$ mais ricos é 26 vezes maior do que a dos $20 \%$ mais pobres e que as elites impedem as reformas que aliviariam a fome, a pobreza e a doença. Os estudos do Instituto de Pesquisa de Economia Aplicada (Ipea) apontam que existem 37 milhões de pessoas situadas numa linha abaixo da linha de pobreza. Conclui Flávia Piovezan (2006, p.311) que o critério para a violência dos direitos humanos no Brasil é o critério econômico, com o qual se conjuga um componente sociopolítico. Nesse sentido, as vítimas, via de regra, não são mais dos setores da classe média, politicamente engajadas, mas pessoas pobres, por vezes excluídas socialmente e integrantes de grupos vulneráveis. O setor agrário prima por reunir essa classe de excluídos, 
e, então, a desumanização ocorre nesse meio de forma mais gritante, registrando violações das mais diferentes ordens. Aqui, serão analisadas as lutas que abrem margem para os maiores desrespeitos.

\section{A luta pela terra}

Quanto à divisão de terras, deve-se observar e relatar a recente reportagem publicada no jornal $O$ Estado de S. Paulo, cujo tema traduz que "os conflitos de terra revelam um país que não saiu do século 19": "O conflito reúne diferentes segmentos na luta pela terra: madeireiros, índios, sem terra, atingidos por barragens, comunidades quilombolas, todos são os injustiçados de um processo que se iniciou com a colonização, e, que ainda não se findou" (Arruda, 2006, p.A4).

Os relatos sobre morte, impunidade, danos materiais e morais sobre os envolvidos na luta pela terra ocupam muitas monografias, mas, nas academias, essa discussão é ainda incipiente. O MST tem buscado trazer à baila painéis que provoquem o estudo da situação fundiária do País. Mas, nas universidades, poucos se ocupam do tema. Em estudos diversos, artigos outros e pesquisas conjuntas com discentes, a autora tratou do tema, até aqui, concluindo que a disputa pela terra é a maior violação aos direitos humanos no meio rural. Dela desencadeiam todas as demais. À guisa de exemplos, pode se montar a seguinte cadeia de desatinos rurais: o homem sem terra, oriundo de um processo perverso de expulsão, não tem para onde ir; perde sua dignidade; não tem cidadania; não tem trabalho; passa fome com sua família; é obrigado a enfrentar qualquer tipo de atividade, para sobreviver; é obrigado colocar seu filho de cinco anos para trabalhar; quando encontra, é obrigado a aceitar trabalho degradante. Nessas circunstâncias, parte para lutar por terra e ainda é chamado de marginal, "vagabundo" ou algo ainda mais depreciador. As raízes dos problemas não são tratadas, mas o remédio amargo para ser dado é imediato quando são estes os "invasores" de terra ou os que clamam pela organização de uma melhoria das condições de vida no meio rural.

Em trabalhos pretéritos, foi analisada a situação agrária do Brasil, no clima de violência e impunidade. Esta autora defendia, em dissertação de mestrado, a não criminalização dos movimentos sociais e, ainda, em tese de doutorado, a situação do trabalhador rural como vítima de um processo 
opressor que deveria ser visto dentro do Direito Agrário e não na visão do Direito do Trabalho, por ser este incipiente na análise sociojurídica rural. Portanto, este relato será sintético em afirmar que a violência no Brasil é de duas ordens: uma institucional e outra estrutural.

Como leciona Juarez Cirino dos Santos (1984, p.90 ss.), a primeira é a produzida direta ou indiretamente pelas instituições políticas do Estado, como aparelhos do poder, instituições de classe que garantem a disciplina das relações sociais conforme exigências e necessidades do poder organizado de classes, constituindo as matrizes normativas da ordem social. Nessa situação, é fácil observar que as leis (o Direito) se pautam nas decisões e vontades de uma classe dominante que controla as relações sociais. No âmbito rural, é nítido quando se observa a oligarquia rural decidindo sobre o universo rural, dizendo sim para os seus interesses e não para os interesses sociais ou, pior, aprovando leis que nunca serão postas em prática, mas que criam a aparência de um direito isonômico. A hipocrisia histórica empregada no meio rural gera a revolta e a luta que hoje se intensifica, jogando por terra os direitos humanos e a esperança de uma vida com dignidade. Nesse setor de violência institucional, ainda há que se revelar a existência da violência dos aparelhos do poder do Estado, como órgãos de garantia coativa da ordem social, disciplinados pelo Direito que reproduz o modo capitalista de produção; e a violência dos aparelhos de poder do Estado criam a ilusão de que a lei e os mecanismos sociais do poder garantem a proteção da liberdade, da igualdade, do bem comum e da justiça. O Estado fornece leis e vigilância, via polícia, Ministério Público e magistratura, mas com violência institucional, de forma a maquiar os fatos e dizer que isso está a serviço do bem comum.

Já a violência estrutural é o que define Santos (1984, p.88) como a violência ligada às relações de produção dominantes e como essa violência atinge, em extensão e intensidades variáveis, o conjunto do bloco dominado. Seu estudo deve obedecer a um esquema que indique como essa violência se distribui pelo conjunto do bloco dominado. A forma mais intensa é posta sobre a força de trabalho ativa na cidade e no campo. Sobre esta última, pode-se dizer que a violência recai sobre os trabalhadores sem terra, proprietários familiares, boias-frias e todos os expulsos das fronteiras agrícolas pela mecanização, pela ausência de crédito rural, pela formação de grandes empresas agrícolas e pela grilagem de terras. A violência sobre estes assume 
formas econômicas e financeiras, pois, sem opção, colaboram empregando sua força de trabalho a troco de salários vis, sofrendo acidentes de trabalho, ausência de direitos, como será visto neste estudo. São esses trabalhadores que, muitas vezes, acabam se marginalizando na periferia das cidades, criando situações de prostituição e criminalidade, transformando-se em vítimas da exploração do lenocínio, do traficante de drogas, em cambistas de jogos, em assaltantes, sequestradores, compondo a área da marginalidade social que produz e reproduz a delinquência, ampliada pela atuação dos aparelhos de controle social como órgãos de reprodução da criminalidade urbana.

Há de se reconhecer o descumprimento da Constituição Federal nas políticas fundiárias. O discurso da reforma agrária não alavanca, com a força que se faz necessária, em virtude do domínio das classes aqui chamadas dominantes, por Cirino dos Santos, mas, neste trabalho, por opção da autora, reconhecida como oligarquia. O governo age de forma tímida, faz o jogo dos interesses, e o Direito, em dose diminuta, toma o partido dos oprimidos e excluídos, gerando essa situação de calamidade que aqui passa a ser revelada, como outrora também já fora revelada por esta autora e por tantos outros pesquisadores do setor rural, que vislumbram no não cumprimento da função social todo um esquema de violência ativa. ${ }^{3}$

Ademais, os dados da violência expressam a situação de desmando no campo e ausência de justiça. Conforme dados expressos no jornal $O$ Estado de S. Paulo (Arruda, 2006), a situação hoje assim se apresenta:

- $27 \%$ é o que se tem a mais de ocupação em relação à área registrada, o que explica o conflito entre clandestinidade e propriedade;

- 111 milhões de terras não são tituladas na Amazônia, portanto a grilagem ocorre livremente;

- 150 mil militantes do MST estão acampados em todo País, o que revela a situação de miséria e desrespeito que vive grande parte do homem do campo, morando em barracas e sujeito a todo tipo de violência;

- 60 mil pessoas integram o Movimento dos Barrageiros, que foram expulsos de suas terras pelas águas das usinas e não foram indenizados, ficando na miséria;

3 A autora deste livro possui diversas publicações abordando a questão da violência rural, assim como outros autores, como Juvelino Strozake, Marcelo Varela e Sérgio Sauer. 
- 600 áreas são reivindicadas pelo Conselho Indigenista Missionário, para recolocação dos índios brasileiros, os reais donos das terras, os quais, estes sim, foram esbulhados e hoje morrem à mingua, em suas parcas aldeias sem recursos;

- 2.100 comunidades quilombolas reconhecidas querem os títulos de suas posses, que remontam à época colonial;

- no oeste do Pará, madeireiros e plantadores de soja disputam terras da União e do Estado-membro, e pistoleiros expulsaram 500 famílias de agricultores da região;

- o governo atual demarcou 9 mil hectares de terras indígenas, e liminar do Supremo Tribunal Federal (STF) suspendeu a decisão, causando conflitos entre fazendeiros e índios;

- no Pontal do Parapanema, no estado mais rico e desenvolvido da nação, há um conflito perene sobre terras, e, hoje, são os filhos dos assentados que clamam por terras que, em sua maioria, nas vizinhanças, são devolutas;

- em Eldorado, cenário do massacre dos sem-terra, o conflito continua, agora entre grileiros e quilombolas;

- em Pinhal da Serra e Anita Garibaldi, divisa dos estados do Rio Grande do Sul e de Santa Catarina, há a disputa pela não construção da usina hidrelétrica que irá desempregar, empobrecer e destruir a região.

Para completar esse cenário de violência, há de se remontar à leitura de Klester Cavalcanti (2004, p.70), em que são revelados 1.373 assassinatos por questões agrárias, registrados no Brasil, entre 1985 e 2003, dos quais somente 122 foram levados a julgamento. Apenas nove mandantes desses crimes foram condenados. Nenhum está preso. Até hoje, conforme revela o autor, do prefeito da cidade ao diretor da escola municipal, passando pelo delegado de polícia e pelo juiz da comarca, nenhum cargo é ocupado sem a benção dos poderosos da região da Amazônia. O relato dos assassinatos e os nomes dos mandantes, dos juízes que tentaram impor justiça e dos que facilitaram as impunidades estão revelados no trabalho de Cavalcanti (2004) que, por cinco anos, catalogou as mortes dos que lutavam pelos direitos humanos dos homens da terra. O livro é uma expressão vergonhosa do que se passa no campo. A obra não entrou para os mais vendidos, não motivou processos de difamação ou calúnia, não projetou a luta, apenas se tornou de interesse de quem busca trabalhar com o tema. 
A história da propriedade da terra no Brasil é a história da exclusão de vários segmentos da sociedade. Diversas foram as correntes de pensamento eurocêntricas que para aqui vieram e influenciaram - e ainda influenciam o cotidiano brasileiro. São marcas na economia, no direito, no social como um todo, tudo reflexo da cópia de um sistema falido na Europa, ou em vias de extinção - as sesmarias, que foram cruciais para a formação dos grandes latifúndios existentes no Brasil (Vial, 2003, p.268).

O latifúndio é a expressão da opressão; por meio dele, dá-se a concentração de terras, a dominação no setor rural, a monocultura, a economia de exportação. Lutar contra ele é lutar contra a fome, a favor da igualdade, da liberdade e da democracia; é a luta pela busca da solidariedade. A luta pela terra traz a mancha do sangue do vitimado, que nada mais faz do que clamar por direitos constitucionalmente garantidos, tanto no artigo $5^{\circ}$ (direitos e garantias individuais) como nos assuntos pertinentes à questão agrária (arts. 184 a 191 da Carta Magna de 1988).

O Brasil criou um modelo jurídico de um reforma agrária redistributiva, por meio do instituto da desapropriação de propriedades rurais que não cumprem sua função social. Mas o País é relutante em pôr essa operação em prática, cedendo aos caprichos dos grandes proprietários rurais e, ainda, às instruções de órgãos internacionais, que se voltam para uma reforma agrária de mercado, onde a relação se dá por meio de compra e venda de terras. O Banco Internacional para Reconstrução e Desenvolvimento (Bird), por exemplo, aponta que a reforma agrária conduzida pelo Estado brasileiro é uma caricatura, como tal inexistente no mundo real. O desenvolvimento rural é vinculado a um projeto neoliberal que, na visão de Mendes Pereira (2006, p.40-1), compartilhada por esta autora, naturaliza e potencializa o modelo agrícola dominante, comandado por grandes empresas multinacionais, agroindustriais e suas ramificações financeiras. Além de ser ecologicamente insustentável, esse modelo desemprega trabalhadores, precariza o contrato de trabalho e tem custos econômicos elevadíssimos. Pereira conclui que esse é o sentido político estratégico de se construir uma nova matriz de poder no campo, surgida no bojo do ajuste estrutural. Essa é a política do Bird, avessa às políticas redistributivas. A luta pela terra também é uma luta contra mecanismos internacionais que, por sua vez, devem cobrar posições dos Estados, a favor das maiorias miseráveis, sob o ponto de vista político, em sociedades altamente desiguais e injustas. 
Yeda Linhares, em trabalhos diversos e, de forma especial, em Terra prometida, em parceria com Francisco Carlos Teixeira da Silva, escreve que reforma agrária foi, durante tempos, identificada como subversão. Assim, grandes empresas madeireiras, pecuaristas e grandes projetos agroflorestais puderam livremente - a maioria utilizando-se dos incentivos fiscais oferecidos pelo governo - se apoderar de terras e explorar o trabalho agrícola, sem temer punições. Da mesma forma, os núcleos de poder conservadores estavam conscientes de que a situação de pobreza crônica do País colocava em risco qualquer processo de modernização imposto. Foi nesse jogo de faz de conta que se tentou mediar uma situação que melhorasse o setor rural, todavia sem tirar o poder de quem sempre dele se beneficiou (Linhares \& Silva, 1999, p.182-3).

Para José de Souza Martins (2000, p.12-1):

Quando se diz que a reforma agrária entrou na agenda política do Estado, ainda que de modo limitado, não é apenas e talvez nem fundamentalmente em consequência da ação do MST e das oposições ao governo. Pois, em termos de conflitividade, ela já estava proposta no regime militar. No meu modo de ver, entrou na agenda do Estado como recurso institucional para atenuar os efeitos politicamente conservadores da propriedade da terra que se manifestam nos problemas sociais e, para acelerar a modernização da elite fundiária e das oligarquias. Neste sentido a ação modernizadora do governo, por essa via tem um aliado fundamental no oposicionismo do MST, da Igreja e do PT quanto à reforma agrária.

Muito embora José de Souza Martins venha se manifestando ostensivamente contra o MST e contra sua luta pela reforma agrária, seus ensinamentos devem ser respeitados e, num padrão democrático, vale a pena discutir seus textos, pela respeitabilidade e erudição de suas produções intelectuais.

Compartilha-se, aqui, do pensamento de Nancy Cárdia (1995, p.78-9) segundo o qual a construção da cidadania democrática exige, como dito ao longo deste livro, algum tipo de controle dos cidadãos sobre os governantes, para que possam se proteger do poder arbitrário destes últimos. Faz-se necessário, ainda, que os cidadãos sintam-se participantes da formulação das leis, para que possam percebê-las como resultado de transações entre iguais 
e internalizá-las. Isso permitiria a ocorrência da pacificação e, consequentemente, o controle da violência.

Os desmandos no campo e a ausência de justiça revelam que, apesar de ser um país agrário, o Brasil não quer assumir seu perfil ruralista, a não ser quando estão envolvidas grandes empresas, lucro, dólares, superávit. A justiça só chega para os grandes; a reforma agrária é incipiente; seu modelo é inócuo, pois não fixa o homem à terra, porque não oferece recursos. $\mathrm{O}$ Estado faz o jogo do grande latifundiário e ilude o pequeno produtor. Desse modo, não há que se falar em democracia e na realização dos direitos humanos. Há muito que se construir.

\section{A luta pelo meio ambiente saudável}

Para Wolkmer (2003, p.20), o humanismo tem representado, independentemente do lugar e do tempo, valores capazes de nortear a conduta do homem. A necessidade histórica do humanismo tem se justificado, em diferentes momentos, como bandeira de luta e de reação em defesa da humanidade. A luta por um ambiente saudável vem ao encontro das metas dos direitos humanos contemporâneos, em defesa do desenvolvimento sustentável e da solidariedade entre os povos.

Nas razões sociojurídicas, encontrar-se-á a preocupação da produção agrária associada à preservação ambiental, na questão da função social da propriedade, já interposta no ordenamento do Estatuto da Terra, em 1964. A vinculação entre um pressuposto e outro já era manifestação explícita, neste ordenamento, cujo objetivo centrava-se na efetivação da justiça social, trabalhando os elementos econômico, social e ambiental. Para a época, a lei agrária era um avanço e sinônimo de desenvolvimento racional e adequado, capaz de reunir pontos estratégicos que poderiam conduzir o processo rural de forma ordenada, propiciando uma reforma agrária capaz de adequar a agricultura brasileira aos modelos considerados ideais pelos padrões modernos.

Muito pouco do Estatuto da Terra foi efetivado. As razões políticas, na efetivação desta lei, foram parte dos impedimentos que, juntamente com a tradicional e conservadora sociedade rural, aproveitaram desse ordenamento somente o que lhes convinha, deixando de lado a parte fundiária que, historicamente, sempre foi o grande marco da concentração de riquezas e, consequentemente, o grande gerador das desigualdades sociais. 
O Código Florestal de 1965 e o Código de Caça e Pesca formam outros ordenamentos que, integrados ao Estatuto da Terra, simbolizam o aparato legal de proteção ao meio ambiente agrário. Portanto, há um bom tempo, já está presente, na esfera jurídica, a preocupação com um desenvolvimento sustentável, ao menos, no tocante às leis. Hoje, há que se falar na Lei de Crimes Ambientais, na Lei de Biossegurança e em outras tantas, como toda a parte referente ao sistema de unidades de conservação, e, ainda, na Lei das Florestas Públicas, em seu uso e manejo, afora todos os organismos criados para dar sustentáculo e apoio às práticas ambientais.

Nos idos dos anos 70, no auge do "milagre econômico", aconteceu, no meio rural, o que foi chamado de Revolução Verde que significou, como bem definiu Tambará (1985, p.15), "a penetração do capitalismo no campo”, visando à maximização produtiva que, objetivamente, usa a natureza para a maximização dos lucros, sem se preocupar com os efeitos da tecnologia empregada sobre o meio ambiente circundante.

Esse momento ficou marcado pela ilusão do aumento desenfreado da produção, com uso de conhecimentos tecnológicos, abrangendo o uso da química, da mecânica e da biologia. $\mathrm{O}$ meio rural brasileiro, piloto dessa experiência, que aparentemente demonstrava ser a saída para o crescimento do setor agrário, foi marcado profundamente por mudanças que permanecem e apontam ser este o único caminho viável. Brum (1988, p.44) passou a definir essa Revolução Verde como

Um programa com o objetivo aparente de contribuir para o aumento da produção e da produtividade agrícola no mundo, através do desenvolvimento de experiências no campo da genética vegetal, para a criação e multiplicação de sementes adequadas às condições de diferentes solos e climas e resistentes às doenças e pragas, bem como da descoberta e aplicação de técnicas agrícolas, ou tratos culturais modernos e eficientes.

O mesmo autor define as duas fases correspondentes a esse fenômeno: uma fase pioneira e experimental, que resultou em pacotes tecnológicos; e a segunda numa intervenção controlada no processo de produção. Em nível de infraestrutura da produção, sobretudo em relação ao uso de sementes, adubos e equipamentos, como também no controle da articulação dos produtores por meio da assistência técnica e orientação do crédito rural. 
Na prática, esses programas foram amplamente aplicados no Brasil, resultando na política agrícola que favoreceu a aplicação do que foi chamado "modelo de desenvolvimento do meio rural", também qualificado como "modernização da agricultura", via pacotes tecnológicos, o que fez desprezar, por seu turno, a opção pela reforma agrária, apregoada no Estatuto da Terra, e gerar quase que o desprezo pela efetivação da função social da propriedade, restando o item de aumento de produtividade como o único capaz de ser cumprido, em face da adoção do modelo "pacote tecnológico". Assim, a lei foi mantida no papel, não sendo cumprida no tocante à redivisão das terras e ao incentivo da agricultura familiar, não sendo capaz, portanto, de conter o êxodo rural; contrariamente, favoreceram-se as migrações, fazendo que a busca pelo emprego urbano inchasse as cidades, destruindo, em grande parte, as reservas ambientais e baixando a qualidade de vida urbana. A afronta aos direitos humanos de terceira geração continuava sendo mantida e, dessa vez, com prejuízos para a natureza e, indiretamente, para o homem. O momento político de progresso juntou-se ao chamado "milagre brasileiro", e a opção do Estado em favorecer a entrada dos pacotes tecnológicos caracterizou-se como, no dizer de Zamberlam \& Froncheti (2002, p.16), providências que resultaram no grande capital imperialista monopolista, em que grandes empresários perceberam que um dos caminhos do lucro permanente era o dos alimentos e, possuindo grandes sobras de material de guerra, direcionaram tais sobras para a agricultura.

Dessa feita, instalou-se no Brasil um mercado favorável a compras de insumos, desenvolvimento de tecnologia estrangeira, aquisição de sementes e adubos, pesquisas, máquinas e equipamentos, estímulo às cooperativas, para proliferação de novas práticas, e mais dramática foi a reformulação do papel do Banco do Brasil, que passou a ser o órgão financiador, por excelência, desse novo modelo.

Não obstante, o campo estruturou-se na via monocultural, prestigiando as grandes extensões de terra e voltando sua produção para o comércio exterior. Houve uma preocupação em proteger o mercado rendoso, à medida que este centrava sua produção em acúmulo de terras e capital, deixando à deriva a questão do meio ambiente e desconhecendo a situação social, o que provocou a organização em busca de recuperação da terra perdida e de outras alternativas de plantio e de sobrevivência. Os trabalhadores rurais que, sem condições estruturais, passaram a ser os párias sociais da 
vida urbana tiveram que promover um retorno ao campo e desde os idos de 1984 organizaram-se em movimentos sociais, buscando novas alternativas de prática agrícola, sustentando suas metas numa opção de modelo que se preocupasse em firmar uma nova estrutura agrária, organizada em centrar um novo modelo de desenvolvimento, que prestigiasse os elementos sociais e ambientais, até então esquecidos, e que promovesse, com certeza, uma reforma agrária esboçada em outros modelos, combatendo-se o tradicional tipo biotecnológico.

Há de se considerar que outras questões foram postas à baila, para se pensar em agricultura alternativa e técnicas diferenciadas do modelo reinante, advindo do neoliberalismo. A preocupação internacional com o meio ambiente, desde as Convenções de Estocolmo, Rio 92 e outras tantas, foi responsável pela pressão em forçar estudos, pesquisas e técnicas que criassem mecanismos favoráveis para o que se chamou de desenvolvimento sustentável.

As organizações não governamentais também foram importantes na luta para formar novas tendências, que encaminhassem políticas e técnicas para um ambiente saudável e para a produção de alimentos com qualidade. O próprio esgotamento de certas reservas ambientais e a preocupação de criar freios na exploração da natureza exigiram que o Direito criasse novas modalidades legais de proteção jurídica e tutela ao meio ambiente, inclusive resgatando a aplicabilidade de leis já existentes, que foram abandonadas por força da opção política.

Muito embora já houvesse o alerta de muitos estudiosos para o retorno ao modelo sustentável, a questão perpassava pelo confronto com o modelo patronal, que havia se tornado a verdade sabida para o campo, nas décadas passadas, e que, no ponto de vista dos defensores do meio ambiente, não permite o desenvolvimento sustentável, uma vez que opta pelo modelo de pacotes agrícolas, incluindo técnicas de biotecnologia importadas, trazidas de outras realidades.

Travou-se, em princípio, uma batalha que, hoje, um pouco diminuta, deixa, sem dúvidas, diversos clamores cruéis de dificuldade governamental a serem resolvidos, como o que deve ser praticado no Brasil: o modelo rentável permite o exercício de práticas avançadas dentro do mecanismo da modernização agrícola, que significa divisas, supersafras, produção abundante, ou deve se ajustar aos novos clamores do direito sustentável, com 
técnicas alternativas, modelos de agricultura familiar que preservam o meio ambiente e se preocupam com os demais elementos que integram a sustentabilidade?

Necessário se faz entender que o desenvolvimento sustentável não se limita a uma conceituação meramente ambiental e ecológica. Costa Neto (1999), ao abordar a questão, argumenta que se poderia ver no modelo biotecnológico uma prática sustentável, com um certo sentido dentro do capitalismo ecológico, ou ainda a agricultura familiar por si só também não basta para garantir um modelo de preservação ambiental. Mister se faz que haja uma reunião de três elementos essenciais à sustentabilidade: a preocupação ecológica ambiental, a estrutura social agrária com base na unidade familiar e o consequente trabalho agrícola associativo e cooperado. Para Costa Neto (1999, p.308-20), as três características mencionadas, quando interligadas, tendem a constituir-se no embrião de uma outra sociedade no campo. Portanto, torna-se inócuo discutir desenvolvimento sustentável somente à luz das questões ambientais. Certamente, a discussão sustentase em técnicas alternativas, por exemplo, que devem ser apresentadas para colaborar para uma melhor qualidade de alimentos, sem degradação da natureza; programas de agricultura familiar, que conduzam a pontos como o tecnológico, o ecológico e o socioeconômico; e, por fim, um ajuste ao modelo de desenvolvimento do País, que implique alternâncias legislativas que possam garantir a viabilidade desses modelos.

Ao seu turno, devem ser questionados os pontos polêmicos sobre a adequação desse modelo para implantação imediata no País. Os discursos devem ser proferidos em busca de soluções viáveis e, acima de tudo, passíveis de ser aplicadas. Surge a polêmica sobre o que plantar, como plantar e quais as técnicas a serem utilizadas, e ainda, que amparadas pelo Direito, essas técnicas devem ser compatíveis com a cultura local, com os interesses nacionais de alimentação, com os recursos hídricos disponíveis, para assim se consolidar a sustentabilidade. Todavia, o alcance dessa meta não é tarefa fácil, uma vez que colide com interesses econômicos dos grandes grupos monoculturais que dominam o agronegócio brasileiro.

Não se despreza, como consequência, a questão da reforma agrária, que reflete qual o modelo a ser seguido na formação dos assentamentos. As técnicas utilizadas nos lotes devem ser compatibilizadas com a preservação ambiental e com o manejo sustentável. 
De pronto, entende-se, pois, que a amplitude do desenvolvimento sustentável exige modelos que alteram a forma do crescimento - e não só que limitam o crescimento. É a sociedade que deverá optar pela forma de seu crescimento e agir em seu próprio benefício. Assim, pode-se dizer que é sustentável, no entender de Boff (1999, p.137),

[...] a sociedade que produz o suficiente para si e para os seres dos ecossistemas onde ela se situa, que toma da natureza somente o que ela pode repor, que mostra um sentido de solidariedade gerencional, ao preservar para as sociedades futuras os recursos naturais de que elas precisarão.

Para tanto, a opção por modelos econômicos produtivos, que garantam ao homem progresso, preservação e relações sociais efetivas, pode se satisfazer nos modelos alternativos, na agroecologia ou em outros modelos que saem da linha tradicional, cuja tecnologia, capital e forma monocultural dominam o mercado de hoje.

Optando por essas novas técnicas, reconstrói-se a ruralidade, e o espaço rural ganha novos contornos que podem, inclusive, ser utilizados como produto de consumo da população urbana. Pessoas que adquirem pequenas propriedades, que se mudam para o meio rural ou, ainda, que passam fins de semana ali anseiam por uma melhor qualidade de vida e contribuem com atividades que se estendem para a jardinagem, hortas, pomares, criações de animais de pequeno porte, às vezes somente para consumo próprio, mas acabam por construir uma nova realidade, trazendo benefícios para as cercanias. ${ }^{4}$ Onde predominam as grandes culturas, raramente seus proprietários moram nas suas terras, os trabalhadores são em pequeno número no campo e, na maioria das vezes, espalham-se nas periferias das cidades; consequentemente, o aspecto social desfalece-se, criando uma ausência de identificação rural, o que resulta no ambiental, no paisagístico e até no econômico, que se resume às plantações para exportações, não criando outros procedimentos ou produtos para a venda interna. Maria Wanderley (2000, p.35) retrata, com veracidade, que a expulsão em massa do contingente de

4 É importante verificar que o meio ambiente cultural também se faz presente na estrutura agrária. População, costumes e tradições são muito mais fáceis de ser mantidos com a agricultura familiar, onde o convívio e a proximidade entre as pessoas se realiza de forma natural, animando a vida social. 
trabalhadores atingiu profundamente a vida rural: a população diminuiu drasticamente, as relações de vizinhança enfraqueceram-se, os contatos sociais e a cooperação deixaram de integrar o cotidiano e o isolamento rural obrigou, muitas vezes, o abandono de seu habitat.

No modelo da agricultura familiar, a vida social poderá ser intensa, atraindo o trabalhador que, mediante situações favoráveis, permanecerá no campo, objetivando uma situação de preservação, valoração de suas terra e produção para sua família e que, em face do modelo apresentado, poderá atrair outras pessoas, que se sentirão num espírito solidário e num ambiente cuja tônica é a melhoria de vida coletiva e, ainda, em nome da sobrevivência, terão de se unir em cooperativas, em reivindicações e, por que não, até em mutirões.

A agricultura familiar agrega, e a monocultura produz isolamento e, consequentemente, êxodo rural, que implica situações funestas para o desenvolvimento sustentável. Os próprios benefícios de infraestrutura somente serão construídos quando a população for definida e clamar por melhorias. Nas cidades, as populações sazonais das periferias, que formam os trabalhadores rurais safristas, não se fixam em imóveis pessoais, por carência financeira e ausência de comprovação salarial; tornam-se miseráveis, não criam laços afetivos com a terra, embora nela trabalhem, e seguem sem perspectivas, sem desenvolvimento e sem sustentabilidade. $\mathrm{O}$ aspecto cultural se perde, deixando o vácuo da preservação ambiental cultural.

Em regiões de floresta ou, ainda, de políticas extrativistas, o homem rural deve cuidar de manter sua atividade de acordo com o que a natureza lhe oferece, promovendo progresso para a comunidade, por meio da exploração racional de seus meios. Trata-se da formação da floresta social, tomada como tal, das técnicas de agrofloresta e das unidades de conservação de uso sustentável. Por exemplo, este foi o trabalho desenvolvido por Chico Mendes: quando na luta pelo desenvolvimento sustentável, organizou, em sua vila, a formação de cooperativas de extração de castanha; agindo dessa forma, manteve seu habitat e propiciou à população condições de sustento e dignidade de vida. Esse fato pode ser utilizado em todas as regiões, partindo-se da premissa de que a natureza, em sendo respeitada, permite que o homem viva dela, sem maiores alterações. Ainda pode ser lembrado que, mesmo as reservas florestais dos imóveis rurais, podem ser utilizadas como meios de uso, desde que adaptadas ao manejo sustentável. Portanto, não há que se falar em perdas econômicas se o bom uso for realizado. 
Os países em desenvolvimento, detentores de patrimônio florestal, devem intensificar sua luta, para que esse patrimônio seja contabilizado no cenário econômico internacional como compensação financeira de suas dívidas externas, sem prejuízo de suas soberanias. As políticas agrárias e as ambientais deverão promover trabalhos conjuntos, com vistas ao estabelecimento de parâmetros para a convivência harmoniosa de assentamentos rurais, no entorno de unidades de conservação, criando uma espécie de cinturão agroecológico, como bem lembra Madeira (2002, p.236).

Ademais, as técnicas hoje propostas permitem que o desenvolvimento sustentável seja aplicado em modelos que visem ao lucro. A partir até de modelos decorrentes do modismo da alimentação, pode-se fazer valer a produção de alimentos que integrem o consumo das populações. A preferência por carne branca, legumes e verduras nas mesas urbanas e nas dietas médicas colaborou para que a agricultura familiar fosse relembrada, e, assim, as justificativas de sua definição vão contribuindo para que a sociedade lhe dê o valor devido.

O turismo rural também, hoje, deve integrar as atividades agrárias, e sua manutenção deve estar a cargo de leis ambientais, para preservar a natureza e mantê-la a serviço de outras gerações.

Em suma, a garantia do meio rural faz-se pelo desenvolvimento sustentável, numa visão ampla e profunda que garanta a questão agrária em níveis toleráveis de progresso, combinados com a qualidade de vida e dos alimentos produzidos, onde o homem deve ser o centro e a meta dos fins desejados.

Pode-se afirmar que o desenvolvimento sustentável se constitui num paradigma que integra as discussões acadêmicas em diversos setores da ciência. Abrange o lado social, econômico e ambiental. Não pode ser analisado em segmentos individuais, mas deve estar interligado nessa perspectiva conglobalizada.

Sob o ponto de vista jurídico, as discussões sobre a questão da sustentabilidade podem ser apreciadas desde a promulgação do Estatuto da Terra, que já observava e determinava o cumprimento da função social pelos os imóveis rurais, num posicionamento que entrelaçava a questão dos recursos naturais, o progresso do homem e suas ligações trabalhistas, sem desprezar o aproveitamento racional e adequado da terra. Com o advento da Constituição Federal de 1988, houve a constitucionalização da questão agrária e o reforço dos itens da função social, que ganharam espaço de re- 
petição do já posto na legislação agrária, no tocante ao dever da propriedade rural. Acresce-se o aspecto de todas as normas ambientais, que regulamentam, em especial, os bens jurídicos repousantes no campo e, ainda, todas as considerações que trazem a lume e as questões voltadas para os transgênicos.

Hoje, o desenvolvimento sustentável é uma propositura mundial que determina o somatório dos itens produção, ambiente e preservação, a fim de que se garanta a geração futura. Para sua efetivação, deve-se pensar em reconstruções de modelos aplicados à questão agrária. Novas alternativas devem ser elaboradas, e a reforma agrária ampla e participativa é condição sine qua non para sua manutenção. Todavia, políticas públicas devem acompanhar e propiciar que os modelos de agricultura familiar se concretizem, e a sociedade civil deve agir e discutir seu papel diante dessas mudanças. Novos modelos de aproveitamento da propriedade rural e até o acompanhamento de técnicas de novas dietas e novos alimentos devem integrar uma recolocação do produtor rural, que, sobremaneira, deverá produzir para garantir seu sustento, mas produzir com qualidade, respeitando os ditames da natureza e, principalmente, o homem, em toda sua dimensão. Só assim o desenvolvimento sustentável terá cumprido seu propósito.

\section{A luta pelo trabalho digno}

O Brasil foi tardio na elaboração de leis trabalhistas. Apenas em 1943, criou seu conjunto de normas voltadas para aquele que se coloca no polo de empregado. A CLT foi traidora com a classe dos trabalhadores rurais, deixando-os de lado e revelando, assim, uma verdadeira discriminação ao homem do campo. O Estatuto do Trabalhador Rural, de 1963, praticamente não vigorou. A Lei ${ }^{\circ} 5.889 / 73$ trouxe um pouco de alento em termos positivistas, mas, na prática, pode-se dizer que o rurícola sempre esteve à sorte de encontrar, ou não, um bom patrão que lhe garantisse seus direitos sociais. Caso que, na prática, torna-se bem difícil, tendo-se em vista a mentalidade do protecionismo, em que perdura a ideia da casa gratuita, da energia elétrica sem ônus, do frango de domingo doado e da horta dividida. Sob essas alegações, o empregador rural não paga os salários e encargos corretamente e se justifica alegando as múltiplas despesas que a ele são atribuídas e seu negócio de risco. 
Em se tratando de relações de trabalho, o cenário mundial vem sofrendo transformações que, no Brasil, já se fazem notar há algum tempo. Com o aumento de encargos trabalhistas, modificou-se também o panorama social no campo. O empregador rural percebeu que não necessita do empregado prestando-lhe serviços, continuamente, em sua terra. O desemprego no campo direciona muitas famílias para a vida na cidade. Muitos desses trabalhadores dispensados formaram um mercado informal do campo. Aliadas a esses fatos, somam-se a reduzida fiscalização existente no meio agrário e as poucas oportunidades de trabalho oferecidas, uma vez que a mecanização tem deixado à margem numerosos trabalhadores e o emprego agrário tem se transformado em oportunidades excepcionais, constituindo, apenas, relações servis nos chamados relacionamentos esporádicos, em que se destaca a figura do boia-fria, também conhecido como volante, que, sem vínculo de emprego, fica à margem do processo jurídico social. O volante, nessa relação de emprego atípica em que se enquadra, depara apenas com os direitos limitados em contratos de trabalho previamente estabelecidos. Movimenta-se entre a cidade e o campo, assimilando valores, entre um e outro, criando conflitos em sua entidade, tentando sobreviver nas safras rurais, com seus ganhos obtidos em trabalho penoso, e deixando seus créditos no consumo urbano, sem, ao menos, estabelecer uma relação empregatícia definida (Maniglia, 2002, p.123).

Em que pese a égide do amparo constitucional e de algumas leis ordinárias, o empregado rural não tem sido senhor de direitos sociais na prática de seu exercício laboral. A violação no setor agrário é chocante.

Com a equiparação constitucional, acreditou-se estar ocorrendo um avanço na legislação. No entanto, é nítida a discrepância entre as duas espécies de relação de trabalho, rural e urbana, pois possuem peculiaridades próprias, não podendo se submeter à mesma lei.

Entendimentos jurisprudenciais atuais reconhecem o vínculo empregatício entre o "boia-fria" e o empregador, pois a relação de trabalho dá-se pelo período aproximado de seis meses, repetindo-se a cada ano. Todavia, há uma grande manipulação para evitar esse fato. Os trabalhadores, na maioria das vezes formando grupos e revestidos do perfil "boia-fria", são levados, a cada período de safra, a uma fazenda diferente pelo intermediador, também conhecido por "gato" que, aliado ao proprietário rural, evita a formação do vínculo de trabalho. A figura indesejada do "gato" dificulta 
ainda mais a condição das turmas de trabalhadores, que, com o temor da falta de trabalho, submetem-se aos ditames impostos por este.

Diante dos direitos garantidos constitucionalmente ou por equiparação jurisprudencial, outro problema enfrentado pelos "boias-frias" é a ausência de empregadores. Com a modernização do campo, os latifundiários ligados às monoculturas investem na modernização do corte da cana-de-açúcar e de outras culturas, além de se utilizarem de outros recursos que suprem o trabalho outrora realizado pelos trabalhadores do campo. A entrada da máquina que substitui 120 pessoas no corte da cana passa a ser outro temor, que faz que o trabalhador se degrade em seu trabalho, aceitando as mais árduas tarefas e condições, sem ao menos questionar a forma contratual e os direitos dela advindos. O jornal Comércio da Franca, que circula na região da cana do nordeste do estado de São Paulo, uma das mais ricas do Brasil, noticiou que o fim da queimada da cana deve desempregar 5 mil trabalhadores na região de Ribeirão Preto. Essa medida decorre do recente protocolo assinado pelo governo de São Paulo que obrigará o fim do corte manual da cana, tendo em conta que este necessita da queimada prévia. A notícia é boa para o meio ambiente, mas assustadora para os boias-frias que, mesmo exercendo um trabalho penoso, têm somente essa fonte de sobrevivência. O presidente do Sindicato dos Trabalhadores Rurais manifesta-se no sentido de que o fim das queimadas atingirá os trabalhadores, suas famílias e também o comércio local. O governo alegou que medidas serão tomadas para atender às famílias, por meio de capacitação dos cortadores para outras funções ("Fim da queimada desemprega 5 mil na região", 2007). Resta o aguardo.

A realidade do boia-fria é de desalento. O contexto muda de acordo com as regiões. No sul, a organização sindical torna menos penoso o esforço dos trabalhadores que veem seus direitos respeitados. A população do meio rural encontra-se abandonada às margens das grandes propriedades que, fazendo olhos nus à função social da propriedade - e o que é pior, com apoio estatal - mantêm as raízes históricas do poder, que impedem o acesso à terra. O trinômio latifúndio-monocultura-economia de exportação, reinante desde a colonização, perpetua a miséria e a concentração da terra, com a consequente concentração de riqueza que acumula miséria, desemprego, degradação ambiental e má qualidade de vida social.

Os trabalhadores desamparados partem, então, para a luta pelo assentamento. Entram na fila do Banco da Terra e esperam por um pedaço de terra; 
filiam-se ao MST e aguardam um pedaço de chão; migram de um Estado para outro, na busca de trabalho; submetem-se a condições equiparadas às de escravo para comer. Desmentindo as estatísticas, são muitos os que tentam todos os meios para sobreviver no meio rural.

Entretanto, quando não encontram refúgio no campo, a promessa de vida na cidade pode lhes parecer atraente, embora não estejam familiarizados com as atividades exercidas pelo trabalhador urbano; assim, voltam-se para os subempregos - quando dão sorte de encontrá-los. O inchaço das cidades é mais um efeito patético, causado pelo descaso para com aqueles que trabalham a terra, tornando-a produtiva e a merecendo. O investimento da iniciativa privada na criação de empregos tem sido tão insuficiente quanto o investimento do Estado na reforma agrária.

Muitos trabalhadores boias-frias, safristas e cooperados têm se filiado ao MST, na busca de melhor condição de vida. Deixam sua condição de empregado ou de "boia-fria" e assumem uma postura final de futuro proprietário. Todavia, muitas vezes, sem sucesso, retornam à condição anterior, submetendo-se, novamente, a uma mera expectativa de possuir um pedaço de chão.

O destino daqueles que se filiam ao MST não é menos desumano, já que nas ocupações são sempre vitimados por ações repressoras e violentas. São agricultores, posseiros que resistem como podem ao ataque de pistoleiros, ora policiais, ora fazendeiros, decididos a eliminar os "subversivos" rurais. Por fim, frustrados com todas as tentativas, são esses os muitos cidadãos(?) que preenchem as cifras da criminalidade, dos suicídios, das mortes trágicas, dos moradores de rua, dos que morrem de fome, de frio e de abandono. Esses, que um dia foram trabalhadores, não mereceram a proteção constitucional, dos direitos sociais, não mereceram a carteira assinada, a aposentadoria, o direito de trabalhar, porque o Direito dos homens lhes negou a justiça e, ainda, condenou-os à marginalidade.

A equiparação entre os trabalhadores urbanos e rurais possui aspectos bons e ruins. Se, por um lado, a equiparação estendeu aos trabalhadores rurais direitos assegurados constitucionalmente (afastando-se, aqui, as discussões sobre a eficácia desses direitos), por outro, fez isso de maneira genérica, isto é, não observou algumas peculiaridades importantes do trabalho rural que poderiam facilitar a aplicação da lei. A principal consequência disso é a dificuldade que têm os órgãos responsáveis de fiscalizar o cumprimento das normas trabalhistas. 
Além disso, sem a devida fiscalização, o trabalhador rural desprotegido procura, cada vez mais, a Justiça Trabalhista para reaver os seus direitos. Perante os juízes, a comprovação dos fatos alegados torna-se difícil (mesmo com uma eventual inversão do ônus da prova) por causa da falta de documentação hábil.

O resultado desses fatores é a fuga do campo, o que acaba por agravar a situação social, também nas cidades, e prejudica o País como um todo, especialmente quando isso se reflete nos índices de produção agrícola.

Assim, em decorrência do contrato de trabalho e do vínculo empregatício, existem alguns direitos trabalhistas, como férias proporcionais acrescidas de $1 / 3,13^{\circ}$ salário, aviso prévio, indenização por demissão sem justa causa ou arbitrária, além de outros direitos, como os previdenciários, a serem usufruídos pelos trabalhadores. Para o empregador, esses direitos transformaram-se em encargos sociais, compreendendo, genericamente, obrigações trabalhistas e encargos previdenciários.

Aos poucos, a Constituição foi promovendo a igualdade dos desiguais. O trabalho rural pleno de especificidade foi, num gesto de "isonomia", igualado ao urbano, como se ambos tivessem tido a mesma história, a mesma cultura costumeira, e como se as formas de utilização fossem, ao menos, semelhantes. Apesar da postura criticada da igualdade constitucional, não se pode negar que os direitos dos trabalhadores foram amparados legalmente, porém longe de serem cumpridos e devidamente fiscalizados.

Em 1994, muitos aproveitadores e oportunistas valeram-se da Lei de Cooperativas e passaram a tratar os boias-frias como sócios cooperados, fazendo que estes se filiassem a cooperativas fraudulentas, o que deixou, mais uma vez, os trabalhadores rurais à mercê de verdadeiros estelionatos sociais.

Ricardo Hajel Filho (2003, p.103) faz os seguintes relatos:

Segundo Raimundo Simão de Melo, Procurador Chefe da Procuradoria Regional do Trabalho da $15^{\text {a }}$ Região, em entrevista concedida para esta pesquisa, assim se posicionou: "a nova Lei tem sido usada em quase 100\% dos casos para fraudar a aplicação do Direito do Trabalho, com consequências danosas, não só para o trabalhador, mas para toda sociedade, pois, além da burla aos direitos trabalhistas, não há recolhimento de INSS, FGTS, ou qualquer respeito às normas de segurança do trabalho". [...] 
No estado de São Paulo, espalharam-se as cooperativas de trabalhadores rurais. As cooperativas, de modo geral, são criadas pelos já tradicionais "gatos", que oferecem "trabalho" aos "boias-frias", condicionando-os ao ingresso em cooperativas já criadas, sendo que alguns desses trabalhadores são arregimentados em outros Estados da Federação.

A prestação de serviços em nada difere da tradicional, a não ser pelo fato de inexistirem garantias trabalhistas. Os trabalhadores são transportados pelos "gatos" e levados a trabalhar de dez a doze horas por dia, nas mais diversas localidades, cumprindo as ordens dos tomadores de serviço ou de seus "turmeiros".

Esse tipo de cooperativa, conforme Hajel Filho (2003, p.104-5):

Contrapõe-se com exemplos de verdadeiras cooperativas de trabalho, como as de trabalho médico, onde os profissionais têm autonomia na direção do trabalho, fixando horários de trabalho e número de atendimentos, paralelamente a outras atividades particulares que desenvolvem. Quando instituída e organizada conforme a finalidade do instituto, este tipo de associação tem como objetivo, em síntese: melhoria da renda de seus associados, na medida em que conseguem reter, para o grupo associado, "a mais-valia", que, numa relação de trabalho, fica em poder do empregador; melhoria das condições de trabalho, na medida em que as cooperativas transformam empregados em empresários, os quais determinam, em comum e de forma democrática, as regras de atuação; melhoria da promoção dos trabalhadores, pois estes, ao adquirirem o status de empresários, tornam-se autogestionários de suas próprias atividades.

Mister se torna deixar claro o tema das cooperativas no meio rural, porque, de uma forma bastante desonesta, esse instituo foi usado pelas multinacionais. Sob a alegação de que a cooperativa é uma forma de economia solidária, aplicou-se o tema, como se para o trabalhador boia-fria fosse esta a solução para seus problemas sociais. Em verdade, o cooperativismo, no setor agrário, é uma grande saída, inclusive para o trabalhador, desde que este, por livre vontade, crie sua cooperativa e esta funcione dentro de todo aparato legal, inclusive com orientação para que o cooperado contribua para com a previdência social, de forma autônoma, para que tenha ciência dos seus reais ganhos, para que participe das assembleias para a tomada de decisões; enfim, para que seja consciente do seu perfil cooperado e que, 
assim, opte consciente por esse caminho. Para tal, espera-se que as políticas públicas conduzam orientações para o alcance desse feito.

O exposto leva à exclusão do trabalhador eventual rural do sistema legal de proteção trabalhista, já restrito e conquistado com muita dificuldade, tardiamente.

A consequência principal dessa falta de incentivos à permanência do homem no campo é a fuga dele para as cidades, agravada pela demora no processo brasileiro de reforma agrária.

Atualmente, há o fenômeno da mecanização. A mecanização dos processos de produção urbana e rural, além de real, é resultado do avanço tecnológico, e seu alcance internacional provém da nova ordem mundial e da globalização.

No Brasil, a Magna Carta de 1988 protege o trabalhador, em face da automação (art. $7^{\circ}$, XXVII). Esse preceito legal admite duas interpretações. A primeira refere-se à substituição do trabalhador por máquinas capazes de efetuar tarefas antes exclusivas dos seres humanos. Já a segunda interpretação reporta à ideia de prevenção dos acidentes de trabalho, envolvendo qualquer tipo de maquinário. De qualquer maneira, a norma constitucional necessita de regulamentação que implemente sua eficácia.

Obviamente, não se trata de coibir o processo de mecanização, importante passo no desenvolvimento do País. Apenas é esperado que a automação não se torne um problema social, gerando desemprego: uma máquina ocupa o posto de mais de uma centena de trabalhadores, afora o fato de poder dar origem a uma legião de mutilados inaptos para o trabalho - muito embora, no trabalho do corte da cana, do sisal e na lavoura em geral, facões e instrumentais agrícolas possam também produzir múltiplos acidentes -, reduzindo ao máximo as oportunidades dos trabalhadores e agravando o quadro crítico do trabalhador rural.

No âmbito agrário, os empregadores defendem a mecanização, dizendo que ela ocorre onde há necessidade de suprir a falta de mão de obra ou ainda quando os trabalhadores não se ajustam às condições de trabalho. Além disso, em seus pensares, a automação apresenta vantagens: redução dos encargos sociais, aumento de produtividade, barateamento da produção e aumento da competitividade do produto brasileiro no mercado internacional. Sem dúvida, não há como não assimilar a mecanização. Mas, para tanto, necessário se faz, em paralelo, pensar no homem e na sua condição de sobrevivência 
ante o desemprego gerado pelo progresso de automatização. Caso contrário, não será possível à sociedade em geral alcançar a tão sonhada paz social.

$\mathrm{Na}$ região de Ribeirão Preto (maior produtora de cana-de-açúcar do Brasil), a mecanização do campo não acabou com o processo de migração sazonal de trabalhadores rurais (provenientes, em sua maioria, do sul e do nordeste de Minas Gerais). Esses trabalhadores chegam à região canavieira atraídos pela possibilidade de emprego nas fazendas e usinas, atualmente bastante reduzida pela automação. Sem meios para voltar às cidades de origem, os trabalhadores permanecem na região de Ribeirão Preto desempregados, o que mostra, na prática, o problema social suprassalientado. Esses trabalhadores são, na maioria dos casos, originários das regiões mais miseráveis do Brasil. São atraídos pelos ganhos altos em números, mas, no aspecto custo-benefício, os ganhos tornam-se perdas, inclusive da vida.

Um dos fatores de agravamento da situação dos trabalhadores rurais tem sido as mortes súbitas, ocorridas nos canaviais de Ribeirão Preto. As mortes chamaram a atenção da Comissão Internacional dos Direitos Humanos, da Organização das Nações Unidas (ONU) e da Organização Internacional do Trabalho (OIT). Segundo as informações do Ministério Público do Trabalho, as investigações encontram-se em curso, uma vez que os corpos foram exumados a pedido de um procurador federal da $15^{\mathrm{a}}$ região, que espera saber se as mortes foram causadas pelo cansaço excessivo.

Relatório elaborado por pesquisadores da Universidade de São Paulo (USP), em parceria com a Pastoral do Imigrante, concluiu que, na década de 1970, o cortador de cana cortava oito toneladas por dia para sobreviver; hoje, esse objetivo somente será alcançado com o corte de doze toneladas ao dia, em média, e a tonelada é paga à razão de $\mathrm{R}$ \$2,40. A socióloga da USP, Maria Aparecida Moraes Silva, que há trinta anos pesquisa o setor, apurou que um trabalhador desfere, em média, 9.700 golpes de facão por dia e perde de 12 a 15 litros de água (os nutrientes saem pelo suor e não são repostos).

A mecanização, que seria a única solução, desencadeia o desemprego de mais de 250 mil trabalhadores que, vindos de outras regiões, não têm o que fazer. A luta pela vida e pelo trabalho esbarra nas condições degradantes que ferem a dignidade. Direitos que buscados se chocam sem, ao menos, uma solução aparente. Trabalhar para viver ou trabalhar para morrer?

A morte por exaustão tem sido um dos temas mais dramáticos no setor de direitos humanos rurais. A "birola", denominação dada à esticada no corte de 
cana para ganhar mais, matou, segundo os dados oficiais, pelo menos 13 trabalhadores nos canaviais paulistas, desde abril de 2004 (Tomazela, 2005a). As razões para as mortes prematuras foram denominadas "exaustão"; causa mortis maior: a miséria, que obriga o trabalhador a exceder seus limites humanos, para ser considerado fixo, ou seja, trabalhador com contrato direto com a usina. Um privilégio, já que a maioria é contratada pelo "gato". Para Aparício Salomão, procurador do Trabalho da $15^{a}$ região, "O trabalhador enfrenta um sistema perverso, o cortador ganha por produtividade e, como esta é baixa, se vê forçado a aumentar sua produção" (apud Tomazela, 2005a).

O caso de Antônio Ribeiro Lopes, narrado pelos jornais, representa bem a situação de um nordestino que deixou seu estado (Maranhão) e foi para Ribeirão Preto em busca de ganhos maiores para sustentar sua família, mas terminou encontrando a morte, possivelmente por exaustão (Tomazela, 2005a). É a triste desolação de um trabalhador vitimado pelo excesso de trabalho, e há muitos casos similares que ainda estão acontecendo no corte da cana, fruto da monocultura e da economia agroindustrial, cujo lucro é o objetivo único. Este, como a maioria, é migrante, vindo dos bolsões da miséria, que, para deixar a fome, enfrenta o corte da cana, com o objetivo de juntar um punhado e retornar à sua casa para garantir o sustento nos demais meses, já que, aqui, o trabalho é sazonal. Para ganhar o suficiente, corta até 19 toneladas de cana por dia e tomba pela exaustão. A Pastoral do Migrante lamenta que a sociedade tenha se mobilizado na defesa dos cortadores apenas após as mortes. O relatório apresentado pela Pastoral classificou a situação dos migrantes como escravidão sutil (Tomazela, 2005b).

Francisco Alves (2006) aponta que a crueldade do sistema se fundamenta na busca da eficiência e da produtividade que deve ter o cortador de cana. São selecionados os mais jovens, reduz-se a contratação de mulheres, optase pela experiência daqueles que, ao menos, cortem 10 toneladas ao dia, em média. Conforme estudos detalhados e precisos de Alves, um trabalhador que corte 12 toneladas realiza as seguintes atividades: caminha 8.800 metros, despende 36.630 golpes de podão; carrega 12 toneladas de cana, em montes de $15 \mathrm{~kg}$, em média, cada um; portanto, faz 800 trajetos, levando $15 \mathrm{~kg}$ nos braços, por uma distância de 1,5 a 3 metros; faz 36.530 flexões de perna para golpear a cana; perde, em média, 8 litros de água por dia, por realizar toda essa atividade sob sol forte do interior de São Paulo, sob os efeitos da poeira, da fuligem expedida pela cana queimada, trajando uma indumentária que o protege da cana, mas que aumenta a temperatura corporal. 
Finaliza Alves (2006):

[...] fica fácil entendermos por que morrem os trabalhadores cortadores de cana em São Paulo [...] Enquanto o setor sucro-alcooleiro permanecer com esta dicotomia interna: de um lado, utiliza o que há de mais moderno em termos tecnológicos e organizacionais, uma tecnologia típica do séc. XXI (tratores, máquinas agrícolas de última geração, agricultura de precisão), mas, mantém, de outro lado, relações de trabalho já combatidas e banidas do mundo, desde o séc. XVIII, trabalhadores continuarão morrendo.

Isso acontece no estado visto como o mais evoluído do Brasil: São Paulo. Também com a migração sazonal, para as regiões produtoras e com a diminuição dos postos de trabalho oferecidos, fortaleceu-se a figura do "gato", nome dado ao aliciador de mão de obra, que funciona como intermediário entre a empresa e o empregado, recebendo por isso. $\mathrm{O}$ acordo é estabelecido entre o aliciador e a empresa, sendo de responsabilidade do primeiro controlar a mão de obra e manter a ordem nos alojamentos. Muito comum é essa prática na região do Pará, onde, volta e meia, esse mecanismo se configura como condição análoga à de escravo, sendo as denúncias apresentadas no exterior do País, como violações aos direitos humanos, por parte de organizações civis, enquanto o governo se omite nos feitos, apenas se limitando a multar os empregadores e a exigir as providências, sem nenhuma outra consequência mais drástica.

O trabalho escravo, no Brasil, tem sido amplamente divulgado pela mídia. Todos os meses, existem denúncias de trabalhadores libertados em estados, onde, por coincidência, registram-se os maiores índices de miséria e menores índices de desenvolvimento humano: Maranhão e Piauí. Também muitos são os casos no Pará, no Mato Grosso, em Tocantins e na Bahia. A situação é sempre similar, não importando o local: os trabalhadores são encontrados dormindo sob lonas pretas ou em alojamentos equiparados a currais, sem higiene, doentes, com carteiras de trabalho retidas (quando estas existem), ameaçados por peões armados e sem dinheiro algum. ${ }^{5}$

5 A página eletrônica <http://www.cartamaior.uol.com.br> possui uma seção especial sobre trabalho escravo no Brasil, onde se podem confirmar os dados citados e verificar outros tantos comovedores. 
Além disso, a existência de intermediários da mão de obra é mais um elemento a explorar o trabalhador, descaracterizando e dificultando a prova da relação de trabalho em juízo. Por essa razão, há a proibição do intermediário em várias legislações estrangeiras. No Brasil, o Código Penal, em seu artigo 207, prevê o crime de aliciamento de trabalhadores, com pena de detenção de dois meses a um ano e multa. O tipo objetivo do crime é angariar (recrutar, atrair, seduzir) trabalhadores com o fim de levá-los de uma para outra localidade, afastadas entre si. Não há possibilidade de aliciamento culposo, já que o tipo subjetivo prevê a necessidade de dolo (vontade livre e consciente de aliciar). O Código Penal prevê a punição da migração aliciada, e não da espontânea. Dessa forma, já que os aliciadores atuam de forma clandestina, e os empregadores não admitem a contratação de seus serviços, torna-se difícil a acusação formal contra os "gatos". Os próprios trabalhadores, porque dependem dos aliciadores para conseguir emprego e alojamento, não confirmam a sua condição de aliciados. Em outros trabalhos, esta autora revela que apenas $40 \%$ dos trabalhadores rurais possuem trabalho o ano todo no meio rural. São estes que aceitam todo e qualquer tipo de trabalho e que formam os 25 mil trabalhadores, em condições análogas às de escravo. Quando recebem os parcos salários, estes só servem para amortizar parte da dívida firmada com os patrões, que não para de crescer e nunca poderá ser quitada (Maniglia, 2006, p.187). As medidas governamentais contra o trabalho escravo estão paulatinamente sendo mais rígidas, ao menos nas fiscalizações, todavia ainda pedem por instrumentos mais eficazes que punam com vigor seus praticantes.

Outra grande preocupação no setor rural é o trabalho infantil. As crianças passam a trabalhar, dependendo da situação da fome, a partir dos 5 anos. Essa realidade pode ser comprovada por uma decisão inédita do Tribunal Regional do Trabalho, da $15^{\mathrm{a}}$ região, com sede na cidade de Campinas, referente a uma criança que já trabalhava havia tempos na colheita de laranja e que teve seu olho perfurado por um prego. A juíza do caso foi obrigada a reconhecer o vínculo de emprego, embora proibido, para efeitos de aposentadoria para a criança se tratar. Ana Diniz (1994) apresenta o relato de centenas de crianças e adolescentes que trabalham no meio rural ${ }^{6}$

6 São 355 depoimentos que envolvem trabalho no meio rural e também trabalho urbano. As entrevistas revelam o abandono do estado em relação a essas crianças. O programa Bolsa Família não é suficiente e será tratado à frente. 
com um único fim: partilhar seus ganhos no sustento da casa, ou melhor, contribuir para a diminuição da fome, já que sua renda é dirigida somente para a sobrevivência. Conforme Diniz (1994, p.69), "o trabalho passa a ser coisa natural, o trabalho vem junto com a consciência de ser pessoa".

O trabalho infantil começa nas pequenas tarefas, como aguar a horta, jogar sementes, fazer comida, limpar a casa, cuidar dos irmãos, e, aos 10 anos, a responsabilidade já está definida e clara para a criança, o ritmo de atividades se estabelece, geralmente pesado. "Torna-se mais fácil para a criança definir as tarefas que faz e separar o que é trabalho do que é cooperação doméstica e, também, definir que é mais importante conseguir dinheiro, do que ajudar em casa" (idem, p.72). Dessa forma, essas crianças já executam tarefas e passam a trabalhar, na maioria das vezes, a preço vil, em situações degradantes, embora seja terminantemente proibido o trabalho da criança e do adolescente até os 16 anos de idade - salvo na condição de aprendiz, a partir dos 14 anos. Os livros, os brinquedos e a infância não integram essas vidas. A OIT tem se voltado para tirar essas crianças do trabalho, ONG e políticas públicas vêm sendo criadas com esse propósito, mas a situação é dramática.

Huzak \& Azevedo (2000) selecionaram centenas de crianças e adolescentes, inclusive com fotos, na lida diária do trabalho. Alguns exemplos:

- Josiane tem 11 anos de idade e trabalha há 4 anos. Profissão: empregada doméstica na "casa grande".

- Com 13 anos e raquítico, um menino pulveriza, sem nenhum tipo de proteção, hortas com agrotóxico.

- Outro, com 10 anos, ajuda a família a amarrar fumo no Rio Grande do Sul.

- Arfando e rouco, um garoto com 11 anos segue o destino do pai, aposentado com asma: cata bucha e amarra fibras no sisal. Horário de trabalho: das 7 às 17 horas.

- Com 7 anos, Éris é cambiteiro, ou seja, ele conduz, de jegue, as folhas de sisal. O irmão, de 3 anos, já começou a aprender a profissão.

- Na carvoaria, meninos de 8 e 9 anos barreiam o forno, para o preparo do carvão, sob o calor sufocante.

- No corte de cana, no Nordeste, os adolescentes de 13 anos estão na lida desde os 7 anos. 
Em Campos, no estado do Rio de Janeiro, calcula-se que 500 crianças e adolescentes trabalhem na safra da cana. Empreiteiros fingem que não veem, os pais fingem que a filharada vai "passear na roça", o Estado "não sabe de nada", e o rendimento é de 3 dólares por dia. São crianças de fibra, com vidas amargas, com brutalidades a serem enfrentadas, sem perspectiva de dias melhores, mas com sonhos de brincar e ser alguém. Contudo, todos excluídos dos direitos básicos de cidadania. Trata-se de uma violência que os direitos humanos não podem permitir (Almeida, 2001, p.86-7). O princípio da não violência desempenha função diretiva na esfera internacional: a luta pela dignidade da pessoa humana é o valor maior.

À guisa de conclusões, pode-se considerar que os magistrados trabalhistas, de algumas regiões, empenham-se contra as fraudes trabalhistas, em parceria com poucos procuradores e promotores. Organizações não governamentais, pastorais da Igreja Católica, representantes da sociedade civil estão se mobilizando em defesa, ao menos, das crianças, mas ainda é pouco. Os trabalhadores rurais novamente estão jogados à sorte. A sociedade que discute direitos humanos universais e que se preocupa com as mazelas sociais urbanas não pode abandonar os trabalhadores do campo, com pena de, amanhã, colher os tristes e lamentáveis frutos desse abandono. O Estado Social Democrático de Direito, ungido na Constituição brasileira, sob essa égide, é responsável por essa situação e poderá pagar muito caro pela omissão na defesa dos trabalhadores do campo. As lutas sociais são as primeiras manifestações. Outras poderão vir, e, somente assim, a decantada dignidade humana, apregoada no artigo $1^{\circ}$ da Carta Magna, poderá se tornar uma realidade para os que alimentam a nação.

\section{A luta pela segurança alimentar}

A cidadania e a dignidade da pessoa humana partem do direito à vida, à alimentação, ao trabalho e da certeza de investimentos na agricultura, que garantam a todos a produção de alimentos e, certamente, a possibilidade de todos poderem adquirir esses bens e ainda que estes sejam de boa qualidade, sem apresentar riscos para a saúde. Conforme Gordilho de Anda (2002, p.16), a pobreza é concentrada na América Latina e no Caribe. Na zona rural, 77 milhões de pessoas vivem nesse meio, sendo 46 milhões delas indigentes. Isso significa que mais da metade das pessoas que vivem no 
campo é pobre e quase a metade delas não pode satisfazer, com sua renda, nem sequer as necessidades alimentares básicas.

Além da pobreza, há desigualdade na distribuição da renda, e, nas últimas décadas, o problema se acentua. Conforme Navarro (2001, p.97):

Muito embora os países tenham expandido suas economias, a pobreza não foi reduzida significativamente, nem melhorou de forma visível a sua segurança alimentar. O chamado desenvolvimento rural não se restringe ao rural estritamente falando, nem exclusivamente ao plano das interações sociais também principalmente rurais - comunidades, bairros e distritos rurais, por exemplo mas necessariamente, abarcam mudanças em diversas esferas da vida social as quais se têm por limite mais imediato de realização o município podendo se estender para horizontes territoriais mais extensos como provavelmente ocorrerá em curto prazo. Parecem assim desaparecer definitivamente o corte rural - urbano e as formas de sociabilidade, igualmente demarcadas por tal segmentação.

Pensar numa melhoria do setor rural representa, para o autor citado, novos processos sociais e econômicos associados à globalização, que envolvam enfoque histórico, desenvolvimento agrícola, área agrícola plantada, produtividade, formatos tecnológicos, economicidade, uso do trabalho como fator de produção, entre outros. Seguidamente, há de se pensar no desenvolvimento agrário referente ao acesso e uso da terra, nas relações de trabalho e em suas mudanças nos conflitos sociais e nos mercados. Hodiernamente, também se computa o desenvolvimento sustentável que prima pela conscientização dos bens da natureza e de seu uso devido, que caminha, por vezes, no trabalho com $\mathrm{ONG}$, associações, cooperativas, variando de região para região. O desenvolvimento rural é também campo de produção de conhecimento e encontra-se sujeito a tradições diversas.

Assim, no Brasil, é preciso redimensionar, reunir e somar essas formas de desenvolvimento, de forma conjunta, para construir um desenvolvimento pleno que assegure melhorias econômicas, capazes de possibilitar a efetivação da segurança alimentar.

Quanto à desigualdade, José Eli da Veiga (2001, p.105) aponta que

[...] quanto menos desigual for uma sociedade, maior será a redução da pobreza engendrada pelo crescimento econômico. Seu impacto é pequeno, quando há 
muita disparidade no acesso à propriedade da terra, ou à educação, ou quando são fortes as distâncias étnicas ou de gênero.

Portanto, em havendo desigualdade e pobreza, não há como se ter segurança alimentar, uma vez que esta, quase sempre, decorre de meios para adquirir alimentos. O desenvolvimento deve ser visto como um processo de expansão das liberdades reais que as pessoas desfrutam. O desenvolvimento rural excludente tem feito que os pobres busquem seus rumos para proclamar seus direitos. Os movimentos sociais do campo são formas de protesto dos pobres da terra, o clamor dos sem-voz, porque não foram ouvidos no devido tempo (Martins, 2001, p.35).

Os movimentos sociais trazem em seus objetivos e metas o fim da fome, que será alcançado pelo acesso à terra. Para tanto, preparam seus militantes sob o slogam do "ocupar, resistir e produzir". A produção de gêneros alimentícios é a meta para manter o povo em situação de luta e ideal. A agricultura é o pilar para acabar com a fome. Com a produção de alimentos, há possibilidades de se lutar contra a fome. Não depende só de vontade política, mas também de disponibilidade de recursos suficientes. É preciso investir no campo, portanto ter recursos para o desenvolvimento agrícola, políticas de acesso à terra (desenvolvimento agrário) e fomento à segurança alimentar, que podem advir de recursos internos e externos, públicos ou privados.

O que se observa é que os países com graus de elevada subnutrição carecem de recursos necessários para gerar o crescimento dos setores produtivos (Anda, 2002, p.20). A opção dos governos locais para investir no setor rural é outra forma de estratégia de garantir a luta pela segurança alimentar. No Brasil, os grandes investimentos públicos para a agricultura estão voltados para o agronegócio, em detrimento da agricultura familiar, ou dos pequenos e médios proprietários, que garantem a alimentação dos brasileiros. A ausência de segurança alimentar reside na política de exportação e, atualmente, também no incentivo que se dá ao plantio de cana para a produção de etanol. ${ }^{7}$ Assusta e amedronta o agravamento da situação da fome e da ausência de alimentos perante a atual política de fomento à cana-de-açúcar.

7 Muito embora o presidente Lula anuncie investimentos para a agricultura familiar, os grandes investimentos são para o setor de etanol, biodiesel, soja e milho para exportação. Quem garante a produção de alimentos para o consumo da mesa do brasileiro são os produtores familiares. 
Onde serão plantados os alimentos, já que a cana se espalha nas terras mais férteis? Haverá alimento barato? Quem terá acesso a eles?

A fome não combina com a democracia. No Brasil, há pessoas com fome, desnutridas. Há pessoas que, mesmo comendo, estão doentes, porque comem mal. As doenças advindas da má alimentação não coadunam com a democracia. A fome, a desnutrição e as doenças ocorrem muito mais no meio rural, historicamente, desde os tempos da colônia e da escravidão. Paradoxalmente, é no ambiente de onde vem o alimento que as pessoas passam fome ou comem mal. As razões foram todas, até agora, apontadas: falta de desenvolvimento rural e desigualdade social, que geram miséria; concentração de terra; exploração do homem, da criança e do adolescente, do meio ambiente - tudo em nome da riqueza, do poder e do dinheiro. São processos complexos que envolvem os direitos, a luta plural da sociedade, a construção de identidades e movimentos para erradicar a fome e garantir o mais simples e importante dos direitos humanos: o direito à alimentação.

De acordo com Flávio Valente (2002a, p.17):

[...] o direito humano à alimentação só se concretiza quando o alimento se transforma em cidadãos bem nutridos, saudáveis, críticos e participativos. O desenvolvimento jurídico da alimentação como direito humano fundamental tem se apresentado em continua progressão. Inicia-se com a preocupação a um nível adequado de vida. Posteriormente, a própria evolução normativa encarregouse de aplicar o direito à alimentação e nutrição a uma variedade de situações: conflito armado, direitos da criança, saúde reprodutiva, discriminação racial.

Cria-se, então, o Direito Humano à Alimentação Adequada, o DHAA, que passa a se preocupar, em especial, com a segurança alimentar. $\mathrm{O}$ desenvolvimento jurídico da alimentação, como direito humano fundamental, tem se apresentado em contínua progressão. A fome, a desnutrição, a ausência de direitos e de aprendizado são formas de desumanização. Sem conhecimento, não se pode aprender a comer bem. Sem se alimentar, não se aprende, e o homem com fome, desnutrido e sem conhecimento é excluído do processo de vida digna.

A fome, a desnutrição e o analfabetismo são facetas de uma vida de miséria imposta a parcela significativa da população brasileira, pelo processo histórico 
de exploração econômica, imposto por um sistema colonialista e imperialista e que conta com a participação ativa de classes dominantes locais e submissas que se beneficiam do mesmo processo. Os analfabetos e famintos são as mesmas pessoas. São aqueles $40 \%$ que, apesar de produzirem grande parte da riqueza de nosso País, somente têm acesso a 7\% da renda distribuída. Onde há crianças desnutridas, há famílias com fome, analfabetas sem autonomia para gerir suas próprias vidas. (Valente, 2002a, p.18)

O povo brasileiro passa fome, apesar de ser um dos maiores exportadores de alimentos. O direito à alimentação adequada é um direito básico, reconhecido internacionalmente. Sem uma alimentação adequada, em quantidade e qualidade, não há o direito à vida e, consequentemente, aos demais direitos. $\mathrm{O}$ ato de se alimentar passa pela cultura de cada povo, pelas formas de acesso para produzir ou adquirir seus alimentos. Todavia, não basta comer. Deverá haver a segurança do que se come, ao menos, para evitar doenças advindas de contaminação de agrotóxicos ou de água.

As práticas agrárias são determinantes para a condução da produção de alimentos bons ou ruins. O processo de urbanização e a migração rural resultam em alimentações falhas e incipientes. A perda dos hábitos rurais, inclusive dos horários destinados à alimentação, é um agravante no processo da segurança alimentar, aliada a outras condicionantes, como desemprego, subemprego, redução do poder de compra, expulsão dos pequenos trabalhadores rurais, avanço da monocultura exportadora e, ainda, dos intensos conflitos, nos quais se produzem cadáveres em série. José Carlos Garcia (1999, p.83) denominou de "sem rosto" esses trabalhadores que vivem nas intempéries rurais e que, pela sua luta em busca das melhorias de vida, inclusive por meio dos movimentos sociais, anseiam por uma melhor condição de vida. Considera o autor que esses trabalhadores somente adquirirão cidadania por meio da luta, inclusive, da luta pela erradicação da fome.

$\mathrm{O}$ direito à terra é um direito humano, pois dela provém o alimento. $\mathrm{Da}$ terra pode vir o fim da fome, portanto a propriedade rural deve estar a serviço dos direitos humanos e do combate à fome, à pobreza e à desigualdade. A segurança alimentar é um direito humano reconhecido, e a luta por sua realização é papel de todos.

A pesquisa caminhou até ao fim deste capítulo de forma ampla, estudando a questão agrária brasileira, sob a ótica dos direitos humanos. Foi 
apresentado um estudo aprofundado sobre os instrumentos jurídicos que permeiam a questão do campo, na ótica agrária, ressaltando a importância deste estudo. As visões constitucional, ambiental e trabalhista constituíram-se em contribuições necessárias e vitais para o bom andamento da pesquisa. Os direitos humanos foram analisados à luz das doutrinas nacional e estrangeira, buscando-se sempre entremeá-los com o Direito Agrário, conectando-se a melhoria da vida no campo à efetivação de políticas públicas, que tragam a concretização dos direitos humanos.

A segurança alimentar, cerne deste trabalho, será, adiante, amplamente abordada, como parte dos direitos humanos. No meio rural, estes estão distantes de uma efetivação; as razões para tanto são várias, sendo as principais delas a ausência de políticas estatais, incentivos, fiscalização e a não realização de uma democracia plena para todos os setores.

Muito há de se lutar, e as academias devem avocar parte dessa luta para si, desenvolvendo, em seus trabalhos com alunos, essa visão agrária, como sendo raiz de uma luta por direitos ainda não consolidados. Esse é apenas um posicionamento de quem, por lutas múltiplas, buscou a implementação de direitos mais humanos no setor rural. 


\section{3 \\ Segurança alimentar}

\section{Estado, bem comum, globalização e alimentação}

Antes de dar início ao tema proposto, é mister recordar que as novas concepções sobre o papel do Estado e das normas jurídicas no mundo contemporâneo são fundamentais para a realização do bem comum. Myrdal (1972, p.73) aponta para o fato de que o Estado se transformou na principal manifestação da sociedade organizada, firmando-se como estrutura de controle de quase todas as interferências exercidas por outras instituições e outros grupos de poder dentro de um país.

Dallari (1980, p.46), sempre pragmático, constata que, no século XIX, em decorrência da influência do liberalismo, o Estado era tido como um mal necessário, mas sempre um mal. No século XX, há de se admitir que o Estado ganha um perfil de importância naquelas tarefas que os grandes grupos econômicos não tinham interesse em realizar.

Nessa evolução, há de se admitir que hoje o Estado ganha a responsabilidade de ter um comportamento voltado para o encaminhamento dos grandes problemas sociais. Pasold (2003, p.44) atribui ao Estado três funções destacáveis. A função instrumental submete o Estado a um ordenamento jurídico e a uma estruturação de procedimento. Os atos do governo são identificados como o Estado tutelando a sociedade e seus integrantes. O compromisso desse Estado passa a ser a sua segunda função: o bem comum, entendido como o interesse coletivo que implica um ordenamento de crenças, valores e informações construídos historicamente e que representa o que se chama de patrimônio social. A interferência na vida da sociedade 
é o terceiro papel que o Estado deve representar. Guarda estreita relação com a condição instrumental do Estado e com sua capacidade de atender às legitimas aspirações da sociedade. Em nome do bem comum, o Estado deve interferir na vida social sem paternalismo, mas com instrumentos jurídicos partilhados entre Estado e Direito criados pelo povo para realização dos fins humanos e do grupo social (Sachez Viamonte apud Pasold, 2003, p. 56).

O Estado contemporâneo volta-se para a defesa dos direitos individuais, consagrados em suas constituições, insere como direitos fundamentais os direitos sociais e/ou coletivos e, para assegurar a efetiva realização desses direitos, estabelece a sua disciplina e a sua intervenção nos domínios econômico e social (Pasold, 2003, p.57). Esse Estado passa a ter poder e função: poder de realizar o bem comum e decidir em nome de uma sociedade que o construiu, e a função de realizar a satisfação das necessidades materiais, dentro dos valores fundamentais da pessoa humana que devem sustentar o bem comum.

Bobbio (1998, p.123) firma esse posicionamento:

[...] esta é característica do Estado democrático: indivíduo e Estado não estão mais armados um contra o outro, mas se identificam na mesma vontade geral, é a vontade de todos que comanda cada um. É necessário colocar o Estado de forma permanente e pró-ativa em função de toda sociedade. Ao Estado é atribuída a função social, ideologia que consagra a responsabilidade deste agente, diante da sociedade como um todo.

Nessa concepção do Estado hodierno, constrói-se um ordenamento constitucional que deve ser coerente com seus propósitos democráticos e sociais. Portanto, compete a esse Estado definir e construir instrumentos jurídicos que garantam o interesse público. Os objetivos definidos nas cartas constitucionais, o estabelecimento dos direitos e das garantias individuais, sociais, aliados à preocupação ambiental, e a adoção da função social na ordem econômica e no direito da propriedade representam um sustentáculo para a efetivação de direitos voltados para o bem comum. Relevantes também se tornam os compromissos internacionais pactuados em tratados e acordos, cujo objeto é a consagração dos direitos humanos. Mas não é tudo.

Os grupos econômicos, a globalização, os grandes negócios e os organismos internacionais da ordem financeira, aliados à preocupação com o 
progresso, o desenvolvimento e as políticas neoliberais, criam impasses e, muitas vezes, impedem a realização do bem comum e determinam o papel do Estado.

Por essa formação perversa da estruturação das políticas públicas aliadas ao domínio histórico dos países ricos, da concentração de riquezas e da desigualdade social, emergem os problemas socais que cabe ao Estado resolver, mas que nem sempre o faz por estar sem a predisposição para as realizações, ou sob pressão, ou, ainda, por não dispor de recursos econômicos. A economia é a grande determinante na realização dos direitos fundamentais básicos. Alimento, saúde, trabalho, ensino estão submetidos à ordem econômica que hoje, no contexto internacional, interliga países ricos e pobres sob o domínio do monopólio global. Chossudovsky (1999, p.14) atribui ao G7 a condução da economia do mundo:

Conforme a recessão aumenta, a economia mundial é dominada por um punhado de bancos internacionais e monopólios globais. Esses poderosos interesses financeiros e industriais entram cada vez mais em conflito com a sociedade civil. Embora o espírito do liberalismo anglo-saxão tenha um compromisso com o fomento da competição, a política macroeconômica do G7 tem sido na prática (por meio de rígido controle fiscal e monetário) responsável por uma onda de fusões (mergs) e compras em corporação, bem como pela falência planejada de empresas de pequeno e médio porte.

Dessa feita, os Estados, principalmente aqueles em via de desenvolvimento, dependem do livre-comércio e da integração econômica, que proporcionam maior mobilidade à empresa global, enquanto, simultaneamente, suprimem por meio de isenções de impostos e barreiras institucionais o movimento do pequeno capital local.

Entende o autor que os problemas da globalização são decorrentes da economia baseada na mão de obra barata, das instabilidades financeiras, das crises fiscais dos Estados, das políticas de dependência do capital estrangeiro, resultando no que Chossudovsky denominou "globalização da pobreza”, que se estabeleceu no mundo desde o inicio a década de 1980: a queda do poder de compra interno, a eclosão da fome e o fechamento de hospitais e escolas. Milhões de crianças ficaram sem direito à educação primária; em várias regiões, doenças infecciosas ressurgiram, como a tubercu- 
lose, a malária e o cólera (idem, p.26). Embora a missão do Banco Mundial consista em combater a pobreza e proteger o meio ambiente, seu patrocínio para projetos hidrelétricos e agroindustriais em grande escala também tem acelerado o processo de desmatamento e de destruição do meio ambiente, causando a expulsão e o deslocamento forçado de milhões de pessoas.

Assim se constituiu o imperialismo das grandes nações que, ao longo dessas últimas décadas, passaram a se preocupar com os desastres ecológicos, com a produção de alimentos para eles - já que são dependentes da importação desses produtos - e também com a fome daqueles que, excluídos do processo econômico, ficam à mercê da ajuda dos grandes países. Mas essa ajuda baseou-se naquilo que Dupas (2006, p.160) qualifica como importância do mercado dos pobres, que foi percebível de forma célere nas últimas décadas. A título de ilustração, a Nestlé do Brasil descobriu que uma lata de leite condensado pode ser oferecida como presente de aniversário em regiões pobres; para tanto, preparou uma embalagem dourada com fita, sem alarde, para não chamar a atenção da concorrência.

Os grandes gurus em estratégia de negócios também estão despertando para os mercados dos pobres. Stuart Hart (apud Dupas, 2006, p.161-2), um dos famosos consultores mundiais de corporações, afirma que, sem incluir os bilhões de pobres que vivem com 1,5 mil dólares por ano, não haverá futuro nem para o capitalismo, nem para as empresas globais. Sugere Hart que as empresas mirem os 4 bilhões da base de pirâmide e que saiam do comodismo em que vivem e passem a dialogar com favelados, população rural, pobres, índios, ambientalistas radicais. Estes devem ser incorporados na cadeia de fornecedores ou consumidores. Desse modo, precisam ser lembrados e tratados com desvelo.

As grandes empresas investem nos projetos de fome e de inclusão social, e, em troca, vendem produtos como celulares, televisores de plasma, aparelhos de som para os pobres. Ou retiram deles seus conhecimentos e produtos naturais, para, em seguida, elaborar um produto e vender a um outro mercado mais exigente, que obviamente paga o suficiente para compensar a transação comercial. No Brasil, a empresa Natura mantém a população ribeirinha e os povos da floresta empregados no extrativismo de castanhas, copaíba, coco, andiroba, buriti e outras plantas nativas. Industrializa esses produtos e os vende para um outro público. Com certeza, sem o conhecimento natural dos povos regionais, esse produto poderia custar bem mais 
caro. As empresas vendem progresso e felicidade para os pobres, anunciam as boas razões mercadológicas para seus produtos, inclusive na indústria farmacêutica, onde a saúde foi transformada em objeto, e o paciente, em cliente (Dupas, 2006, p.183 ss.).

Pela imposição das vendas, do progresso e dos mercados, o planeta foi sendo destruído e gerando outros problemas para o homem. Os ricos poluem porque produzem e consomem. Os pobres poluem porque, sem infraestrutura e sem recursos, são obrigados a destruir o meio ambiente ou fazer deste mecanismo de renda. Com essa destruição, a natureza está sendo corroída, e o homem está sujeito a toda modificação para pior do seu modo de vida. A população mundial tende a crescer, apesar do refreamento nas taxas de fertilidade, a população mais idosa galgou melhores índices de longevidade, e, nos países pobres, a juventude ainda fará sua população crescer. Isso significa que os alimentos, apesar de toda tecnologia, poderão ser escassos. Mas também significa que, com o aumento da população e o avanço tecnológico, as taxas de emprego são ameaçadas, a população deixa de ter renda, e a miséria circunda os pobres. Os ricos, por sua vez, dentro da ótica ambiental, querem se assegurar de garantir seu habitat e seus alimentos, e, consequentemente, uma batalha trava-se internacionalmente.

Busca-se, desse modo, criar uma sustentabilidade, a qual Ignacy Sachs (2002, p.71) denomina de "sustentabilidade social", que, a seu ver, vem à frente da ambiental, por destacar-se como a própria finalidade do desenvolvimento, sem contar com a probabilidade de que um colapso social ocorra antes da catástrofe ambiental. Em seguida, esse autor descreve a sustentabilidade cultural como corolário da social e a sustentabilidade econômica, que é uma necessidade, mas em hipótese alguma é condição prévia para as anteriores, uma vez que um transtorno econômico traz consigo o transtorno social que, por seu turno, obstrui a sustentabilidade ambiental. O mesmo pode-se dizer quanto à sustentabilidade política que, em seu entendimento, é soberana no processo de reconciliação do desenvolvimento com a conservação da biodiversidade.

Assim, pode-se concluir que o termo "sustentabilidade" tem vertentes múltiplas e que o Estado deve galgar a:

Sustentabilidade social, por meio da distribuição de uma renda justa, patamar de homogeneidade social razoável, emprego pleno e/ou autônomo com vida decente, igualdade no acesso aos recursos e serviços sociais. 
Sustentabilidade cultural, com capacidade de autonomia para elaboração de um projeto nacional integrado e endógeno (em oposição à cópias servis dos modelos alienígenas) mudanças no interior da continuidade (equilíbrio entre respeito à tradição e inovação), autoconfiança combinada com a abertura para o mundo.

Sustentabilidade ambiental, respeitar e realçar a capacidade de autodepuração dos ecossistemas naturais.

Sustentabilidade econômica, desenvolvimento econômico intersetorial equilibrado, segurança alimentar, capacidade de modernização contínua. Dos instrumentos de produção razoável nível de pesquisa científica e tecnológica e inserção soberana na economia internacional.

Sustentabilidade política, democracia definida em termos de apropriação universal dos Direitos Humanos, desenvolvimento da capacidade do Estado para implementar o projeto nacional em parceria com todos os empreendedores, um nível razoável de coesão social.

Sustentabilidade da política internacional, eficácia do sistema de prevenção de guerra da ONU, na garantia da paz e na promoção da cooperação internacional. Pacote de codesenvolvimento firmado em regras baseadas em igualdade. Controle institucional efetivo do sistema internacional financeiro e de negócios, controle institucional efetivo da aplicação do princípio da precaução do meio ambiente. (Sachs, 2002, p.85-7)

Outras sustentabilidades são consideradas, como a territorial, ecológica e de cooperação científica, visando todas ao bem da humanidade.

Enfim, o Estado, para galgar a efetividade dos direitos humanos, está adstrito a uma série de normatizações, fatores internacionais, variáveis múltiplas nas relações entre pobres e ricos, concepções do progresso, pressões das grandes empresas, o que dificulta e obstrui, muitas vezes, os objetivos daquilo a que se propõe como meta.

$\mathrm{O}$ direito, como agente de justiça social, deve ser o grande impulsionador da formação da cidadania. A cidadania passa pelo ser pessoa-ninguém pode ser cidadão sem ser pessoa. O político e o jurídico têm um pré-requisito existencial. A cidadania acresce o ser pessoa, projeta no político, no comunitário, no social e no jurídico a condição de ser pessoa. Não há como florescer a cidadania se não se realizam as condições de humanismo existencial (Herkenhoff, 2001, p.88). 
No mundo, são muitos os que não podem ser pessoa, são milhares os que não têm o que comer, que são desnutridos, que vivem à margem social. São párias na escala social, que terão seus descendentes também como párias. Herkennhoff (2001, p.89) afirma que são párias porque estão à margem de qualquer direito, à margem do alimento que a terra produz, à margem da habitação que a mão do homem pode construir, à margem do trabalho e do emprego, à margem do mercado, à margem da participação política, à margem da cultura, à margem da fraternidade, à margem do passado, do presente e do futuro, à margem da história, à margem da esperança. Só não estão à margem de Deus, porque em Deus confiam.

Essa é a face negativa da cidadania, criada por modelo socioeconômico de cunho internacional que revela a fome e a miséria dos povos. Portanto, estuda-se, a partir deste momento, a segurança alimentar.

\section{Segurança alimentar na perspectiva internacional}

\section{Conceito, evolução, tratados, comércio e ajuda}

A vida humana é o bem mais considerado em todas as esferas globais, portanto deve ser garantido em todas as suas formas, não apenas no plano da sobrevivência, mas também nas condições saudáveis da existência e dignidade. Aqui, estabelece-se o direito à alimentação que é muito mais do que comer para sobreviver. Alimentar-se é um ato que projeta mais que sobrevivência, é uma permissão a uma vida saudável e ativa, dentro dos padrões culturais de cada país, com qualidade que propicie nutrição e prazer, e os produtos alimentícios devem ser inspecionados por órgãos responsáveis, que devem zelar continuamente por sua oferta e sua segurança às populações.

Conforme Ana Paola de Castro Lins (2007):

[...] no passado remoto, a alimentação era um ato natural, ou seja, o homem trabalhava algumas horas para conseguir os alimentos necessários a si. A evolução trouxe a divisão do trabalho e a troca entre produtores, o que começou a transformar este ato natural. Esse aspecto se aprofundou com o capitalismo, através da mercantilização. Com ele, não basta só trabalhar para comer, o trabalho significa salário e este é transformado em produtos no mercado, onde os 
preços, qualidade e quantidade de mercadorias disponíveis sofrem processos complexos de determinação. $\mathrm{O}$ ato da alimentação, portanto, não mais se faz de forma natural e isso talvez seja irreversível. A frase bíblica "comerás o pão com o suor do teu rosto", deixou de ser uma verdade. Para a grande maioria da população do planeta, o ato de alimentação depende de complexos mecanismos de decisão dos produtores capitalistas, do papel de intervenção do Estado, dos subsídios da agricultura, do grau de concentração da terra e do capital investido na indústria alimentar, entre outros.

A alimentação está vinculada ao acesso a produtos de boa qualidade, que devem existir com suficiência no mercado, mas, sobremaneira, está vinculado às condições econômicas de adquirir esses alimentos. Portanto, a pobreza é a inimiga número um da sustentabilidade alimentar. A pobreza gera a fome e origina-se, na maioria das vezes, na desigualdade social, na concentração de rendas, no desperdício, na exploração dos pobres, nas guerras entre os povos, nas omissões dos Estados e na corrupção destes, no aumento das doenças, na exploração desordenada dos recursos naturais, na ganância dos ricos e na ausência de solidariedade dos povos.

A pobreza gera a desnutrição, que pode ser entendida como a consequência de um processo contínuo de carência alimentar: ingerindo menos calorias (energia) do que o necessário para o desenvolvimento adequado, a pessoa não se desenvolve. Mas não é só. Hoje, muitas pessoas no mundo sofrem de outros problemas decorrentes da má alimentação. Embora tenham acesso à alimentação suficiente, passam por problemas de obesidade e outras doenças decorrentes das carências nutricionais a uma vida saudável.

Os dados no mundo da pobreza revelam: cerca de 100 milhões de pessoas estão sem teto; há cerca de 1 bilhão de analfabetos; 1,1 bilhão de pessoas vivem na pobreza, destas 630 milhões são extremamente pobres; aproximadamente 1,5 bilhão de pessoas não têm água potável; 1 bilhão de pessoas passam fome; 150 milhões de crianças, com menos de 5 anos, são subnutridas (uma para cada três no mundo); 12,9 milhões de crianças morrem a cada ano, antes de seus 5 anos de vida; 24 milhões morrem de inanição todos os dias (Helene, 2006).

Muitas foram as manifestações em defesa dos pobres, mas o ano de 1996 representou o marco mundial com a preocupação da segurança alimentar no mundo. Em Roma, 185 países mais a Comunidade Europeia reuniram-se 
para discutir a fome do mundo e, num ato protocolar, comprometeram-se a erradicar a fome de todos os países, tendo como objetivo imediato o de reduzir pela metade, até 2015, o atual número de pessoas desnutridas. Ficava então instalada a Declaração de Roma sobre Segurança Alimentar.

As raízes intrínsecas desse ato foram motivadas pela situação intolerável, quando 800 milhões de pessoas não tinham alimento suficiente para satisfazer suas necessidades nutricionais básicas. Reafirmaram o direito à alimentação adequada e o direito básico de todos estarem livres da fome. A realização e a implementação do direito à alimentação adequada deve ser objeto central de todos os Estados e de outros atores, a fim de erradicar a fome e a desnutrição.

Não era, entretanto, a primeira vez que se tratava do tema.

O conceito de segurança alimentar foi introduzido na Europa, a partir da I Grande Guerra; sua origem esteve profundamente ligada à ideia de segurança nacional e a capacidade de cada país produzir sua própria alimentação, de forma a não ficar vulnerável a possíveis cercos, embargos ou boicotes de motivação política ou militar. (Paraná, 2006)

Há de se ressaltar, como já foi mencionado no Capítulo 1, que o Direito Agrário tem como marco o fim da Primeira Guerra Mundial e sua positivação, em 1922, na Itália, exatamente com a preocupação de estabelecer normas para atividade agrária, visando à produção de alimentos. O Direito Agrário é o grande ramo jurídico impulsionador da atividade agrária, responsável pelo abastecimento alimentar no mundo. Portanto, deve estar incluído nas agendas jurídicas dos povos de todas as nações, e suas normas devem estar fixadas para o interesse público, como um grande ramo do Direito Público e em consonância com as políticas públicas dos direitos humanos. E mais, em harmonia com o meio ambiente, parceiro inseparável do Direito Agrário, que, nessa conexão, garantem ao homem uma vida saudável e próspera.

O tema da fome, no entanto, volta à tona em 1974 quando a escassez de alimentos de 1972 a 1974 passou a assustar o homem e, por conseguinte, tornou-se tema de discussão nos acordos estabelecidos na Conferência Mundial de Alimentação de 1974, mais uma vez diante do perigo da escassez de produtos agropecuários. 
A segurança alimentar era compreendida como uma política de armazenamento estratégico e de oferta segura e adequada de alimentos, e não como um direito de todo ser humano a ter acesso a uma alimentação saudável. O enfoque estava no alimento, e não no ser humano. Com o aumento da produção de alimentos, nos fins da década de 1970, o mundo despertou para a realidade e passou a encarar a situação da fome e desnutrição como um problema realmente de acesso e não de produção. $\mathrm{O}$ aumento da população deixou de ser preocupante, já que havia meios de produzir muito e avanços tecnológicos constantes.

Já em 1983, a Organização de Alimentação e Agricultura das Nações Unidas (FAO) apresentou um novo conceito de segurança alimentar, que se baseava em três objetivos:

- oferta adequada de alimentos;

- estabilidade da oferta e dos mercados de alimentos;

- segurança no acesso aos alimentos ofertados.

O Banco Mundial, em 1986, definiu segurança alimentar como "o acesso por parte de todos, todo o tempo, a quantidade suficientes de alimentos para levar uma vida ativa e saudável".

Nesse ínterim, passa-se a visão de que alimentos na mesa significam poder aquisitivo e não autossuficiência na produção. Poder aquisitivo representa crescimento econômico, distribuição de renda e redução da pobreza.

A partir de 1990, já com a questão da sustentabilidade em discussão simultânea com o meio ambiente, mais uma modificação foi feita ao conceito de segurança alimentar. Englobaram-se ao conceito:

- noções de alimento seguro;

- qualidade do alimento;

- balanceamento da dieta;

- informação sobre os alimentos;

- opções de hábitos alimentares em modos de vida.

O direito à alimentação passou a se inserir no contexto do direito à vida, à dignidade, à autodeterminação e à satisfação de outras necessidades básicas.

Em 1992, a Conferência Internacional de Nutrição, promovida em conjunto pela FAO e Organização Mundial da Saúde (OMS), atribuiu uma 
face humana ao conceito de segurança alimentar. Estimulou a assistência ao uso adequado da água, saneamento, saúde pública, aleitamento, carinho no preparo dos alimentos.

Posteriormente à Conferência de Roma, a segurança alimentar passou a ser entendida como um direito humano básico à alimentação e nutrição. Esse direito deve ser garantido por políticas públicas, e o aspecto público deve ser entendido, aqui, por uma esfera onde agem tanto agentes públicos como privados. O papel do Estado é proteger esses direitos durante quebras de produção, calamidades naturais, desemprego, quedas de salários reais e piora das relações de troca, além de promover a cidadania.

Fundamenta-se a participação ativa da sociedade civil por meio de suas organizações, onde o Estado é incapaz de agir por sua falta de flexibilidade e capilaridade. Deve-se romper com a ideia de que o mercado se opõe aos Estados e que a sociedade civil tem seu papel complementar. Esse é um momento crucial porque o espírito solidário é manifesto, atribuindo a todos o dever de reduzir a fome no mundo e colaborar para a minimização dela.

A partir de 1996, passa-se a conviver com o Código de Conduta sobre o direito humano à alimentação adequada, composto de 15 artigos que se voltam para a efetivação da justiça social, requerendo a adoção de políticas econômicas, ambientais e sociais tanto em âmbito nacional como internacional, orientadas para a erradicação da pobreza e para a satisfação de necessidades básicas. Há de se destacar o artigo 5.5 que estabelece que "alimento nunca deve ser usado como instrumento de pressão política e econômica”.

Para Valente (2002b, p.189),

esse Código de Conduta renova o compromisso dos Estados e o apoio de todos os atores relevantes para garantir o direito à alimentação adequada e o fortalecimento da implementação desse direito. Como preocupação central desse compromisso, devem estar os pobres e os que passam fome em um ambiente econômico, como o atual, permanentemente em transformação.

O direito à alimentação adequada é um direito humano básico, estabelecido por leis internacionais baseadas na universalização dos direitos humanos, cuja validade é perene, e a intransponibilidade, um requisito essencial. Diante da indivisibilidade dos direitos humanos, Flávia Piovezan (2007, p.25-6) reafirma que não há direitos humanos sem que os direitos econômi- 
cos, sociais e culturais estejam garantidos. Por isso, devem ser reivindicados como direitos, e não como caridade, generosidade ou compaixão. Piovezan (2007, p.26) busca em Asbjorn Eide e Allá Rosas sua fundamentação:

Levar os direitos econômicos, sociais e culturais a sério implica, ao mesmo tempo, um compromisso com a integração social, a solidariedade e a igualdade, incluindo a questão da distribuição de renda. Os direitos sociais, econômicos e culturais incluem como preocupação central a proteção a grupos vulneráveis. [...] As necessidades fundamentais não devem ficar condicionadas à caridade de programas e políticas estatais, mas devem ser definidas como direitos.

Há na sociedade, ainda, uma má interpretação. Quando os Estados se voltam para as políticas de erradicação da fome, são muitos os que interpretam essa postura como política de assistencialismo ou benesse dos órgãos públicos, inclusive alegando o desatino do uso das verbas públicas. Tal fato acontece de maneira corriqueira, principalmente quando os países que tomam essas medidas são corruptos ou trazem em seu histórico o abuso e desvio do dinheiro público. Esses fatos favorecem essas interpretações, mas, de qualquer forma, não são posturas corretas. Muito embora os pobres sejam usados como meios para desvios de verbas públicas, estes não devem e não podem ficar à deriva de direitos, em face das desonestidades de políticos mal-intencionados.

O direito à alimentação foi resultado da Carta das Nações Unidas da Declaração Universal dos Direitos Humanos em 1948, que é marco da criação do Direito Internacional dos Direitos Humanos. Porém, como aponta Renato Maluf (2007, p.51), nos Estados Unidos, a convite do então presidente Roosevelt, em 1943, os Aliados reuniram-se e houve uma primeira discussão sobre alimentos e agricultura. Posteriormente, a criação da FAO, em 1945, e da OMS, em 1948, foi de suma importância para a questão alimentar, assim como a criação, em seguida, do Fundo das Nações Unidas para a Infância (Unicef). A ideia era amenizar a má nutrição por intermédio de iniciativas como enriquecer alimentos básicos e reduzir algumas deficiências. $O$ trabalho foi paulatino, e todas as discussões sobre o tema chegaram à determinação de que a alimentação é um direito.

Em 1966, com a elaboração de dois tratados, no âmbito das Nações Unidas, o Pacto Internacional dos Direitos Civis e Políticos e o Pacto Interna- 
cional dos Direitos Econômicos, Sociais e Culturais, ficou ajustado entre 145 Estados-partes um vasto rol de direitos, como o de garantia a um nível de alimentação adequada, moradia, trabalho, educação, saúde, previdência social, com aplicação progressiva. Vale dizer que esses direitos dependem do esforço dos Estados e da cooperação internacional. Outros documentos trataram do tema, como a Declaração Universal sobre Erradicação da Fome e Desnutrição, em 1974, lembrando que:

todo homem, mulher, criança tem o direito inalienável de estar livre da fome e da desnutrição, para que possa se desenvolver integralmente e manter sua faculdades físicas e mentais, enquanto considera que a sociedade atual já possui recursos suficientes, habilidade organizacional e tecnológica, portanto para atingir este objetivo. (Valente, 2002b, p.189)

A Declaração dos Direitos dos Portadores de Deficiência Física, de 1975, proclamou o tema da alimentação como direito. Nas provisões da convenção sobre a eliminação de todas as formas de discriminação contra as mulheres, em 1979, e na Declaração do Direito ao Desenvolvimento, de 1986, foi assegurado o direito à alimentação. A Declaração dos Direitos da Criança, de 1959, e a Convenção dos Direitos da Criança, de 1989, reconheceram o direito de toda criança ter um padrão de vida adequado ao seu desenvolvimento físico, mental, espiritual, moral e social. A Convenção da Organização Mundial do Trabalho n ${ }^{\circ} 169$, relativa aos povos e às tribos indígenas em países, também declara o direito à alimentação adequada (Valente, 2002b, p.190).

Outras reuniões, documentos e cúpulas internacionais também trataram do tema: Conferência Mundial da Alimentação (1974), Declaração de Princípios e Programas de Ação da Conferência Mundial sobre Reforma Agrária e Desenvolvimento Rural (1979), Cúpula Mundial da Criança (1990), Conferência Internacional sobre Nutrição (1922), Declaração e o Programa de Ação da Conferência Mundial de Direitos Humanos de Viena (1993), Declaração e Programa de Ação da Cúpula Mundial para o Desenvolvimento Social de Copenhague (1995), Conferência de Pequim sobre a Mulher (1995) e Declaração de Roma sobre Segurança Alimentar e o Plano de Ação da Cúpula Mundial de Alimentação (1996). Também o debate sobre meio ambiente sempre traz à baila a discussão dos alimentos, pela sua 
íntima relação com a preservação das espécies, o uso do solo e o manejo da produção agrícola, e o próprio uso dos recursos naturais.

Amplamente discutido no plano internacional, o tema do direito à alimentação precisa, na prática, ser mais elaborado para facilitar sua implementação. A criação de diretrizes e compromissos é necessária para que seja efetivado o compromisso de erradicação da fome até 2015, muito embora seja unânime que esse objetivo não será alcançado, haja vista a situação presente.

São mais de 800 milhões de pessoas sem alimento para satisfazer suas necessidades básicas. Este é um número assustadoramente elevado e difícil de ser reconciliado com o compromisso expresso [...] Há uma grande tarefa a ser levada a cabo, antes que todos possam usufruir deste direito humano fundamental; é preciso, portanto, examinar a lacuna existente entre os compromissos com os direitos humanos e a realidade hoje. (Asbjorn, 2002, p.208)

Os últimos dados da FAO apontam que houve uma diminuição de apenas 3 milhões de famintos, com referência ao período de 1990 a 1992, e, pior, que a desnutrição aumentou em três das quatro regiões em desenvolvimento: África subsaariana, Ásia Pacífico, Oriente Médio e norte da África. Na América Latina e Caribe, houve uma leve diminuição. O indicador de que a modesta meta seria alcançável é dado pelos resultados em 30 países (Brasil, China e Índia incluídos) que reduziram em 25\% a prevalência da desnutrição no mesmo período (2006) (Maluf, 2007, p.64).

O compromisso de 1996 foi significativo, porém as medidas tomadas ficaram muito aquém do que seria necessário para confrontar, de forma efetiva, os níveis atualmente existentes de fome e insegurança alimentar no mundo. A meta de reduzir os famintos só para 2015 foi vista como um ultraje aos povos famintos. A tecnologia e as grandes empresas são capazes e têm plenas condições de produzir alimentos e nutrição suficientes para todos os seres humanos do planeta. O que falta é decisão política. A convivência com essa situação de miséria e condição humana degradante é inaceitável sob o ponto de vista moral, ético e humano.

Os governos que estiveram presentes em Roma não deliberam em assinar o documento final, o que demonstra o descaso com a situação, e a mínima participação de chefes de Estado demonstra a falta de compromisso dos 
estadistas. Por exemplo: da América Latina e do Caribe, só compareceram três presidentes - Cuba, Haiti e Paraguai; o Brasil foi representado pelo ministro da Agricultura.

A decisão global de se ter um documento único para as medidas universais foi trocada para os governos aplicarem o plano de erradicação da fome da forma que for apropriada. Isso faz que os pobres fiquem vulneráveis a suas próprias misérias.

De positivo, ficou pontual que a insegurança alimentar decorre sempre de uma situação de miséria e que a alimentação adequada, para aqueles que não podem fazê-lo de forma independente, deve ser o acesso aos recursos produtivos. Fixou-se, ainda, não haver divergência quanto ao fato de o direito à alimentação e à nutrição ser um direito essencial. Bill Clinton, em uma feliz manifestação americana, afirmou que o direito à alimentação é o mais básico dos direitos. ${ }^{1}$

Da Cúpula Mundial de Roma, veio a reafirmação de que o direito à alimentação adequada é resultante da Declaração dos Direitos Humanos, de 1948, e do Pacto Internacional dos Direitos Econômicos, Sociais e Culturais, de 1966, que ressalta, em seu artigo 11, que: "Os Estados Partes concordam em adotar individualmente ou por meio de cooperação internacional medidas relevantes para assegurar o direito de estar livre da fome". Destarte, foi estabelecido um Código de Conduta para fornecer um fundamento ético e orientação legal para o acompanhamento do plano de ação da comunidade internacional, dos Estados e atores sociais.

O Código de Conduta estabelecido visa esclarecer o conteúdo do direito à alimentação adequada e as responsabilidades de todos os atores envolvidos na garantia de sua completa realização. O código é escrito num contexto de mudanças da situação da fome e desnutrição decorrente de avanços tecnológicos sem precedentes que apresentam novos riscos, oportunidades e desafios; da mudança de papéis das instituições, tanto em nível nacional, como internacional; e da abertura de fronteiras num mundo cada vez mais globalizado. (Valente, 2002b, p.191)

1 Discurso proferido em 16 de outubro de 1997, Dia Mundial da Alimentação. Essas palavras também já tinham sido de Roosevelt, que afirmou que estar livre da fome é um direito fundamental. Passagens narradas por Asbjorn (2002, p.208). 
Acima de tudo, o Código de Conduta perfaz-se num guia para a conduta internacional, para os países mirarem-se e constituírem suas políticas públicas, e para toda a sociedade cível guiar-se para um encaminhamento de ações sobre pessoas e grupos passíveis de fome e desnutrição. De uma forma ou de outra, isso aconteceu sem muita determinação, mas ocorreu.

Para implementar essa vontade política, os líderes mundiais assumiram os sete compromissos a seguir elencados, que foram registrados no Plano de Ação:

1) Assegurar um ambiente político, social e econômico estimulante, destinado a criar as melhores condições para a erradicação da pobreza e para uma paz duradoura, baseada na participação integral e igual das mulheres e homens, o que é mais conducente para se alcançar a segurança alimentar, sustentável para todos.

2) Implementar políticas que se destinem a erradicar a pobreza e a desigualdade e melhorar o acesso físico e econômico por todos, continuamente, a uma alimentação suficiente, nutricionalmente adequada e segura e sua utilização biológica efetiva.

3) Implementar políticas e ações participativas e sustentáveis, alimentares, agrícolas pesqueiras, florestais e de desenvolvimento rural nas áreas de alto e baixo potencial, que são essenciais para o suprimento alimentar adequado e confiável em âmbito domiciliar, nacional, regional e global e para combater pestes, secas e desertificação, levando em conta a característica multifuncional da agricultura.

4) Empenhar-se para assegurar que as políticas para o comércio de alimentos, produtos agrícolas e para o comércio em geral favoreçam o fomento da segurança alimentar para todos, por meio de um sistema de comércio mundial justo e orientado para o mercado.

5) Tentar evitar e estar preparado para desastres naturais e emergenciais causados pelo homem e para enfrentar necessidades alimentares transitórias emergenciais por meios que encorajem a recuperação, a reabilitação, o desenvolvimento e a capacidade para satisfazer necessidades futuras.

6) Promover a alocação ideal e o uso de investimentos públicos e provados para fomentar os recursos humanos, sistemas alimentares, agrícolas, pesqueiros e silvícolas e de desenvolvimento rural sustentáveis, nas áreas de alto e baixo potencial. 
7) Implementar, monitorar e dar seguimento ao Plano da Ação, em cooperação com a comunidade internacional. (idem, p.192 ss.)

O item 7 é de suma importância para que todos os países possam se mobilizar e pôr em ação os esforços também pactuados no artigo 11 do Pacto Internacional sobre Direitos Econômicos, Sociais e Culturais, que trata da alimentação adequada.

Nos países, o Código de Conduta tem representado um mecanismo a ser seguido também por órgãos como Fundo Monetário Internacional (FMI), Banco Mundial, OMC e as transacionais, em relação à promoção do direito à alimentação adequada. Desde setembro de 2001, vários governos articulam-se para propor a inclusão da proposta na Declaração da Cúpula Mundial de Alimentação. Todavia, esse código não tem caráter vinculatório.

Não existe, entretanto, uma indicação única, com um proceder uniforme para o problema. Sempre que possível, os interesses pessoais dos países sobrepõem-se aos interesses de alimentação dos povos. As discussões sobre alimentos passam pelas discussões da agricultura, e, aí, os grandes tentam aprovar seus interesses.

Em 2001, na reunião da Cúpula Mais Cinco (outra reunião sobre discussão alimentar), coube aos Estados Unidos e à Inglaterra o papel de forçar a aprovação de um documento de caráter voluntário sobre o direito de alimentação (cada qual estabelece sua política de forma independente) e ainda o apoio ao fortalecimento à pesquisa de organismos geneticamente modificados. ${ }^{2}$ Em âmbito internacional, as reuniões discutem sempre a questão da agricultura, pois esta é sempre um grande incômodo para os países desenvolvidos que dependem das importações de produtos alimentares dos países em via de desenvolvimento. Alimentação e agricultura não se desprendem.

Há de se considerar, para a pesquisa em tela, a importância dada aos elementos agrários e ao desenvolvimento rural, sob o ponto de vista internacional. A agricultura é a principal atividade econômica que incide diretamente sobre as possibilidades de superação dos enormes desafios sociais enfrentados pelo meio rural.

2 A reunião tinha como objeto a discussão de apenas dois pontos: a questão da insuficiência de vontade política e de recursos para a implementação do plano-ação, e os participantes pretendiam aprovar, com a sociedade civil, um documento que fosse a favor do código obrigatório. 
O progresso agrícola favorece o crescimento de outras atividades econômicas, por meio de diversos tipos de vinculações, por exemplo, um maior rendimento disponível possibilita o investimento na produção local de bens e serviços; do mesmo modo, aumenta a demanda local, estimulando assim essas atividades; finalmente, também se favorecem as oportunidades de desenvolvimento de atividades locais, tanto para o fornecimento dos insumos requeridos pela agricultura, como para a utilização e comercialização dos produtos agrícolas na região. Em suma, a agricultura tem um peso fundamental na economia de muitos países, constituindo-se num elo vital das cadeias agroindustriais e agroalimentares. (Anda, 2002, p.17)

Hoje, a segurança alimentar global deve ser separada, não podendo ser confundida com autossuficiência. Ela faz parte da internacionalização da questão alimentar.

Nestes termos, a segurança alimentar global e a de cada país seriam melhor obtidas através da existência e do bom funcionamento de um mercado mundial de alimentos. Dependeria do bom funcionamento de um mercado de alimentos, no entanto, a primazia conferida ao comércio internacional com a abertura comercial e desregulamentação dos mercados baseia-se numa opção falsa: buscar a autossuficiência absoluta na produção interna dos alimentos necessários versus ser eficiente nas trocas com o exterior por meio da especialização naqueles produtos em que se é mais competitivo de modo a importar todo o restante. Ela é falsa, porque tal contraposição não encontra correspondência no modo como os países enfrentam historicamente a questão alimentar, além de obscurecer os fatos cruciais. Primeiro, a produção doméstica de alimentos tem condição estratégica para todos os países do mundo. Segundo, o comércio internacional não é fonte confiável de segurança alimentar e nutrição. (Maluf, 2007, p.54)

Isso faz que a autossuficiência não seja sinônimo de segurança alimentar, uma vez que a produção para o abastecimento de um país é diversificada e se mescla em exportações versus importações. Os sistemas alimentares não se esgotam no interior das fronteiras nacionais ou em sentido inverso. As grandes corporações multinacionais e as redes comerciais que hoje dominam desde a venda das sementes até a comercialização são acobertadas pelos Estados nacionais e referendadas pelos organismos internacionais. A 
formação de blocos regionais reforça esse procedimento neoliberal, que foi acentuado nos anos 1990 .

Maluf (2007, p.56), de forma resumida, descreve:

As relações internacionais constituem via de mão dupla, daí que para assegurarem mercados externos para as exportações os países periféricos são obrigados a abrirem seus próprios mercados e a ficarem sob o impacto dos bens importados, que num bom número de casos recebem elevados subsídios nos seus países de origem Esse impacto vai além do percentual do mercado doméstico, ocupado pelos bens importados, com a subordinação da determinação dos preços internos às tendências dos preços internacionais afetando principalmente, a pequena agricultura.

Não obstante, mais uma vez, temos a acentuação da miséria no campo, submetida sem condições ao mercado internacional dentro de padrões daquilo que resolveram denominar de modernização e eficiência, o que, na realidade, reproduz a exclusão.

Os acordos internacionais que se iniciaram com o Acordo Geral de Tarifas e Comércio (Gatt), até a atual OMC, constituem uma das problemáticas mais complexas, em que a regulamentação do comércio dá margem a importantes conflitos. A atual rodada de Doha de negociações da OMC (intitulada rodada do desenvolvimento) contém referências à segurança alimentar e ressalta, no artigo 13 da declaração que iniciou essa rodada, que os países considerados em desenvolvimento terão tratamento especial e diferenciado no tocante à segurança alimentar e ao desenvolvimento rural.

Em verdade, as negociações interagem de forma muito mais privada do que no sentido público. Desconhecem a importância específica da produção interna de alimentos e como ela é combinada nos distintos países com o comércio internacional dos produtos agroalimentares. Por fim, supõem que o comércio internacional, como tal, é fonte confiável de segurança alimentar, o que está longe de ser verdade para os países de Terceiro Mundo, já que ele não assegura a geração das rendas de exportação necessárias para importar alimentos, nem garante a oferta interna regular de alimentos a preços reduzidos (Maluf, 2007, p.59).

O comércio internacional não está dissociado do modelo dominante e agora está acrescido com os transgênicos, dentro da filosofia de que quanto maior a produção de alimentos, maior o abastecimento no mundo e menor a 
pobreza. O que não é verdade. Há muito, sabe-se que os impactos do atual modelo geram exclusão dos pequenos produtores, poucos empregos, poluição, escassez de recursos naturais, problemas de saúde e transtornos culturais.

A FAO, nas suas limitações de exigir dos países comportamentos eficazes, age muito mais com a preocupação de produzir alimentos. Está voltada para a agricultura, com um conjunto de formulações que prioriza a pequena e média agricultura de base familiar, o comércio local e a integração dinâmica com a agroindústria alimentar. Seu trabalho trouxe bons efeitos para a América Latina. As linhas de segurança alimentar para esse organismo baseiam-se em suficiência, autonomia, estabilidade, equitatividade e sustentabilidade.

Também se destaca em seu programa conjunto com a OMS sobre normas alimentares internacionais, cujos objetivos são proteger a saúde dos consumidores e assegurar práticas equitativas de comércio de alimentos - o denominado Codex Alimentarius.

Os programas de ajuda alimentar são, na verdade, muitas vezes, os grandes vilões para os produtores locais. As ajudas representam a venda de alimentos baratos ou doações, ${ }^{3}$ que acabam refletindo sobre a produção dos pequenos produtores de alimentos, assim como afetam o perfil de consumo desses países. Os programas, para funcionarem, devem respeitar a soberania dos povos, permitindo a eles o que plantar, o que comer e que as doações sejam originárias dos pequenos produtores locais.

No que tange à sociedade civil, há de se falar que existem associações de agricultores com vários recortes, organizações não governamentais, ${ }^{4}$ redes internacionais, como a Via Campesina, ${ }^{5}$ entidades ambientalistas, entidades de ordem religiosa, ${ }^{6}$ representações de consumidores e um amplo leque de iniciativas, com as mais variadas conotações, como o Slow food. ${ }^{7}$

3 Na verdade, os produtos doados são escoamentos de excedentes de países do Primeiro Mundo.

4 O Greenpeace é um exemplo de ONG, com atuação em diversos países, em defesa do meio ambiente natural e cultural.

5 A Via Campesina é um movimento internacional que congrega organizações regionais e nacionais de camponeses, pequenos e médios produtores, trabalhadores, mulheres e comunidades indígenas, da Ásia, América, Europa. Sua atuação é para promover o meio ambiente, a segurança alimentar e a defesa dos pequenos produtores.

6 A Igreja Católica, em todo o mundo, tem atuação em defesa da terra e em proteção aos que lutam em defesa da reforma agrária.

7 Slow food é um movimento global, voltado para preservar e difundir as heranças agrícolas e alimentares associadas com os prazeres da gastronomia e da convivência, idealizados por uma associação da cidade de Bra, na Itália. 
De importante sobre esse lado civil, fica que hoje eles adquirem um papel de destaque, tendo em conta sua mobilização internacional e sua atuação simultânea em diferentes locais, funcionando, por vezes, como organismos de pressão junto aos órgãos públicos e privados. A segurança alimentar e as questões ambientais estão se tornado discussões de primeira ordem internacional e têm aglutinado os mais diferentes grupos e movimentos sociais. Muitos deles querem, inclusive, substituir o nome "segurança alimentar" por "soberania alimentar", o que na doutrina é visto com maus olhos, por igualar noções com estatutos distintos: soberania e os objetivos da segurança alimentar e nutricional.

O novo milênio aponta 1,2 bilhão de pessoas em todo o planeta (incluindo mais de 500 milhões de crianças) vivendo abaixo da linha da pobreza, definida pela ONU como pessoas que vivem com menos de 1 dólar/dia, o que seria o mínimo necessário para a sobrevivência. Segundo o estudioso norte americano Phillip Harten, de cada 100 pessoas no mundo, 13 passam fome diariamente. Ainda, para o Fórum Brasileiro de Segurança Alimentar e Nutricional (2007a), umas das maneiras de medir a qualidade de vida de um país é por meio da observância da taxa de mortalidade infantil dos menores de 5 anos de idade, considerada como o número de crianças que morrem antes de completar 5 anos de idade, para cada mil nascidos vivos. $\mathrm{Na}$ identificação das causas da mortalidade infantil, há de se sublinhar que saúde e nutrição são fatores interdependentes, ou seja, só há saúde por meio de uma boa alimentação, e, ao mesmo tempo, é necessário um organismo saudável para aproveitar todos os elementos que uma boa alimentação oferece. Os países com menores taxas de mortalidade infantil são Japão, Noruega, Cingapura, Suécia e Suíça, com média de 4 crianças/por mil nascidas vivas. O Brasil, em 1999, estava na faixa 40 crianças/mil nascidas vivas, dividindo sua posição com o Vietnã. Acima do Brasil, encontravam-se Argentina, Uruguai, Paraguai e México. Por curiosidade, os Estados Unidos e Cuba dividem a mesma $158^{\mathrm{a}}$ posição.

Essas cifras realmente ainda são alarmantes, e fica difícil conciliar o compromisso expresso dos Estados de garantir a todas as pessoas o gozo dos direitos humanos. $\mathrm{O}$ atendimento dessas necessidades, em que pesem os esforços e protocolos internacionais, é insuficiente. Mesmo a construção de blocos econômicos, buscando a integração dos comércios, não solucionou as defasagens elementares. Na América Latina, a Associação Latino- 
Americana de Integração (Aladi) e o Sistema Econômico Latino-Americano (Sela) chegaram a desenvolver projetos de cooperação e assistência voltados para a segurança alimentar regional. Seus êxitos foram escassos. O Mercado Comum do Sul (Mercosul) não atribuiu relevância à segurança alimentar, pelas razões que expõe Maluf (2007, p.8):

Isto se deve, em parte, porque esta região concentra alguns dos principais exportadores de produtos agroalimentares do continente com políticas comerciais orientadas pela visão da liberalização comercial e do acesso aos mercados dos países avançados.

A retórica adotada, quando da constituição do bloco regional do Sul, era a de que a integração entre esses países e a deles com os principais mercados do mundo deveriam se realizar com base nos chamados mecanismos de mercado. Ao contrário, a União Europeia centrou sua preocupação na questão agrícola e na segurança alimentar, como se verá logo adiante.

É necessário examinar a defasagem existente entre os compromissos contraídos a respeito dos direitos humanos e a realidade hodierna, já que a Comissão de Direitos Humanos tem afirmado que a fome constitui uma ofensa e uma violação à dignidade humana. Leis, intenções, compromissos são muitos, o que realmente falta, de um modo ou de outro, é a distribuição de alimentos nas prateleiras de maneira mais equitativa, justa e solidária.

\section{A segurança alimentar na União Europeia}

Em particular, a União Europeia tem desenvolvido um trabalho digno e de alto valor para a segurança alimentar, principalmente no que se refere à sua aplicação interna e em benefício de seus povos. Tal referência é um trabalho que, desde a formação do seu bloco econômico, tem dado prioridade para o setor agrário, inclusive estabelecendo normas de Direito Agrário de caráter funcional e de cunho ambientalista, formando um profissional da agricultura.

A política agrária, conforme Delgado de Miguel (1998, p.62-3), insiste nos objetivos comuns do tratado de Maastricht e procura uma política que reúna meio ambiente, segurança alimentar, seguridade, indústria, saúde 
pública e cultura, numa total convergência de proteção com ajudas a importação e subvenções a exportações, e, ainda, com medidas sanitárias e fitossanitárias, que regulam os produtos produzidos em seu interior e os que vêm por meio de importações.

A segurança dos alimentos é uma das prioridades máximas na Europa, e sua nova abordagem é bem mais integrada, já que a rastreabilidade dos alimentos é assegurada desde a exploração agrícola até a mesa do consumidor. Os riscos dos alimentos são avaliados atentamente, e a União Europeia, quando pode, vale-se dos aconselhamentos científicos para autorizar ou proibir qualquer produto, ingrediente aditivo ou organismo geneticamente modificado (OGM). A União tem incentivado cada vez mais os seus agricultores a privilegiar a qualidade não só dos alimentos, mas também do meio rural. Seus consumidores têm informações precisas e rotuladas, assim como os pareceres científicos são amplamente divulgados, de modo que os consumidores têm confiança na segurança de sua alimentação.

Garantir os mais elevados padrões de segurança dos alimentos na União Europeia constitui uma das principais prioridades políticas da Comissão Europeia. Portanto, torna-se válido apreciar um dos documentos de suma importância que assim define algumas de suas estratégias.

1. A política alimentar da União Europeia deve ter por base padrões elevados de segurança dos alimentos, que permitam proteger e promover a saúde dos consumidores. A produção e o consumo de alimentos são fundamentais em qualquer sociedade e tem consequências económicas, sociais e, em muitos casos, ambientais. Embora a proteção da saúde seja sempre prioritária, estas questões devem, igualmente, ser tomadas em consideração no âmbito da política alimentar. Além do mais, o Estado e a qualidade do ambiente, designadamente dos ecossistemas, podem afetar diversas fases da cadeia alimentar. A política ambiental desempenha, pois, um papel importante quando se trata de garantir ao consumidor a segurança dos alimentos.

2. O setor agroalimentar reveste-se de importância fundamental para a economia europeia. A indústria alimentar e das bebidas é um dos principais sectores industriais na UE, com uma produção anual de quase 600 mil milhões de euros, ou seja, cerca de $15 \%$ da produção total da indústria transformadora. No plano mundial, a UE é o maior produtor neste setor. A indústria 
alimentar e das bebidas é o terceiro maior empregador da União Europeia no sector industrial, com mais de 2,6 milhões de trabalhadores, 30\% dos quais em pequenas e médias empresas. Por outro lado, a produção anual do setor agrícola ascende a cerca de 220 mil milhões de euros assegurando o equivalente a 7,5 milhões de empregos a tempo inteiro. As exportações de produtos agrícolas e alimentares atingem cerca de 50 mil milhões de euros por ano. A importância econômica e a onipresença dos alimentos na nossa vida implicam que a segurança dos alimentos deve ser um dos principais interesses da sociedade em geral e, em particular, das autoridades públicas e dos produtores.

3. Deve ser oferecida aos consumidores uma vasta gama de produtos seguros e de elevada qualidade provenientes de todos os Estados-membros. É este o papel essencial do mercado interno. A cadeia de produção alimentar torna-se cada vez mais complexa. Para assegurar uma proteção adequada da saúde dos consumidores, todos. Os elos desta cadeia devem ser igualmente sólidos. Este princípio deve aplicar-se quer os alimentos sejam produzidos dentro da Comunidade Europeia, quer sejam importados de países terceiros. Uma política de segurança dos alimentos eficaz deve reconhecer as interconexões que caracterizam a produção alimentar. Tal política implica a avaliação e o controle dos riscos que apresentam, para a saúde do consumidor, as matérias-primas, as práticas agrícolas e as atividades de processamento dos alimentos exigem medidas regulamentares eficazes para gerir esses riscos e impõem à criação e funcionamento de sistemas de controlo destinados a supervisionar e assegurar o cumprimento dessa regulamentação. Cada elemento faz parte de um ciclo: assim, as evoluções no âmbito do processamento dos produtos alimentares podem exigir modificações da regulamentação existente, ao passo que as informações provenientes dos sistemas de controle podem ajudar a identificar e gerir os riscos existentes ou potenciais. Cada parte do ciclo deve funcionar adequadamente para que seja possível assegurar o cumprimento das mais rigorosas normas de segurança dos alimentos.

4. A abordagem da segurança dos alimentos deve, assim, ser global e integrada. Tal não significa que a UE deve ser exclusivamente responsável por todos os aspectos da segurança dos alimentos. No entanto, é indispensável que todos os aspectos da segurança dos alimentos sejam abordados em nível comunitário. A título de exemplo, a legislação da UE deve ser aplicável 
de modo eficaz nos Estados-membros, de acordo com o princípio da subsidiariedade. Assegurar a sua aplicação deve competir, em. primeiro lugar, às instâncias nacionais, regionais e locais. No entanto, o mercado. Interno implica que estas responsabilidades não são exclusivamente nacionais: cada Estado-Membro tem obrigações, não só para com os seus próprios cidadãos, mas também perante todos os cidadãos da União Europeia e dos países terceiros, no que respeita aos produtos alimentares produzidos no seu território.

5. É necessário sublinhar que a cadeia alimentar europeia é uma das mais seguras em nível mundial e que, de um modo geral, o sistema atual tem funcionado bem. As medidas de segurança dos alimentos fazem parte da legislação europeia desde o início da comunidade. Historicamente, estas medidas foram desenvolvidas principalmente numa base setorial. Todavia, a crescente integração das economias nacionais no mercado único, a evolução das práticas agrícolas e de processamento dos alimentos e os novos padrões de manipulação e distribuição tornam necessária a nova abordagem que é descrita no presente Livro Branco. Durante as recentes crises no setor da alimentação humana e animal, os sistemas de segurança dos alimentos da Comunidade e dos Estados-membros estiveram sujeitos as pressões sem precedentes. Estas situações de emergência puseram em evidência deficiências que exigem medidas por parte das autoridades responsáveis (Comissão, Estados-membros e Parlamento) no intuito de reforçar, melhorar e desenvolver os sistemas existentes.

6. A segurança dos alimentos deve ser organizada de modo mais coordenado e integrado. Tal permitirá abordar as deficiências existentes, criando simultaneamente. Um quadro de segurança dos alimentos de vanguarda a nível mundial, que permitirá assegurar um nível elevado de saúde pública e de proteção dos consumidores, em conformidade com as exigências do tratado CEE. Todavia, nem o sistema mais completo poderá funcionar sem a plena colaboração de todas as partes interessadas. $\mathrm{O}$ bom funcionamento de qualquer sistema depende decisivamente do empenhamento dos EstadosMembros e dos operadores, bem como dos países terceiros.

7. A União Europeia deve restabelecer a confiança do público no aprovisionamento alimentar, nos conhecimentos científicos, na legislação alimentar e nos controles realizados neste sector. O presente Livro Branco sobre segurança dos alimentos define um vasto conjunto de acepções necessárias para 
completar e modernizar a legislação alimentar da UE em vigor, torná-la mais coerente, compreensível e flexível, promover uma melhor aplicação dessa legislação e proporcionar maior transparência aos consumidores.

8. O princípio orientador do presente Livro Branco é que a política de segurança dos alimentos deve basear-se numa abordagem global e integrada, ou seja, ao longo de toda a cadeia alimentar ("da exploração agrícola até à mesa"), em todos os sectores alimentares, entre os Estados-membros, nas fronteiras externas da UE e dentro da UE, em instâncias de decisão internacionais e comunitárias e em todas as etapas do ciclo de elaboração de políticas. As bases da segurança dos alimentos previstas no presente Livro Branco (pareceres científicos, recolha e análise de dados, Regulamentação e controlo informação dos consumidores) devem articular-se num conjunto harmonioso que permita concretizar esta abordagem integrada.

9. Importa definir com clareza os papéis de todos os intervenientes na cadeia alimentar (produtores de alimentos para animais, agricultores e produtores/operadores de alimentos para consumo humano, autoridades competentes dos Estados-membros e países terceiros, Comissão, consumidores). Os produtores de alimentos para animais, os agricultores e os operadores do sector alimentar são os principais responsáveis em matéria de segurança dos alimentos; as autoridades competentes controlam e garantem a observância desta responsabilidade através dos sistemas nacionais de vigilância e controlo; a Comissão avalia através de auditorias e inspeções, a nível nacional, a capacidade das autoridades competentes de gerir estes sistemas. Os Consumidores devem também reconhecer que lhes compete armazenar, manipular e preparar adequadamente os alimentos. Desta forma, a política "da exploração agrícola até à mesa", que abrange todos os setores da cadeia alimentar, incluindo a produção de alimentos para animais, a produção primária, o processamento dos alimentos, a armazenagem, o transporte e o comércio retalhista, será aplicada sistematicamente e de forma coerente.

10. Uma política alimentar eficaz implica a rastreabilidade dos alimentos para consumo humano e dos alimentos para animais, bem como dos respectivos ingredientes. É necessário introduzir procedimentos adequados para facilitar a rastreabilidade, entre estes importam referir a obrigação, por parte das empresas do sector alimentar e da alimentação animal, de dispor de procedimentos adequados para retirar do mercado os produtos alimentares 
e os alimentos para animais sempre que exista um risco para a saúde dos consumidores. Os operadores devem igualmente manter registros adequados dos fornecedores de matérias-primas e de ingredientes, para que seja possível identificar a fonte de um eventual problema. Convém sublinhar, no entanto, que o rastreio inequívoco dos produtos alimentares e dos alimentos para animais, bem como dos respectivos ingredientes, é uma questão complexa que deve ter em conta a especificidade dos diferentes sectores e produtos.

$[\ldots]$

17. A Comissão recebe um grande volume de informações sobre questões relacionadas com a segurança dos alimentos. As principais fontes de informação são as redes de controlo e vigilância da saúde pública (em particular os sistemas de notificação de doenças transmissíveis previstos na Decisão $\left.n^{\circ} 2.119 / 98\right)$, os planos de vigilância das zoonoses e dos resíduos, os sistemas de alerta rápido, os sistemas de informação no sector agrícola, as atividades de investigação e controle das radioatividades no ambiente e as redes de investigação associadas. Todavia, os sistemas existentes foram desenvolvidos independentemente, pelo que a coordenação das diversas fontes de informação nem sempre é assegurada. Além do mais, uma grande parte da informação disponível não é integralmente explorada. A integração dos sistemas de recolha de dados e as análises dos dados devem constituir os dois princípios de orientação neste domínio, a fim de explorar o melhor possível os atuais sistemas de recolha de dados. A Comunidade necessita de um sistema global e eficaz de controle e vigilância da segurança dos alimentos, que integre todas as fontes de informação acima referidas. A experiência do Centro Comum de Investigação da Comissão poderá proporcionar um apoio útil neste domínio. O primeiro objetivo deverá consistir na gestão permanente e quotidiana das informações, a fim de permitir responder em tempo real aos perigos potenciais. Em segundo lugar, um sistema desta natureza deverá permitir à Comissão desenvolver um papel mais prospectivo e de antecipação. Deve visar à identificação precoce de perigos potenciais a fim de evitar que surjam situações de crise, em vez de atuar apenas em reação a essas situações. Deve igualmente facilitar a planificação política a longo prazo e a definição de prioridades.

18. De um modo geral, o Sistema de Alerta Rápido para produtos alimentares funciona adequadamente no que respeita aos produtos alimentares desti- 
nados ao consumidor final. Existem vários outros tipos de sistemas de notificação em domínios diferentes, como as doenças transmissíveis nos seres humanos e nos animais, os produtos animais apreendidos nas fronteiras externas da UE, a circulação de animais vivos e o sistema Ecurie em caso de emergência radiológica. Mas também neste caso a utilização integrada das informações é difícil, dada à diversidade dos objetivos e do âmbito desses sistemas. Além do mais, alguns domínios como, por exemplo, a alimentação animal, não são abrangidos. É necessário criar um quadro jurídico global e harmonizado a fim de alargar o âmbito do atual Sistema de Alerta Rápido a todos os produtos alimentares destinados ao consumo humano e animal. Esse quadro deverá prever o alargamento das obrigações dos operadores econômicos de notificar as emergências em matéria de segurança dos alimentos e de garantir a informação adequada dos consumidores e das organizações profissionais. Deve igualmente ser assegurada uma ligação adequada com outros sistemas de informação rápida. Este sistema deve abranger também os países terceiros no que respeita às informações recebidas e fornecidas.

19. A excelência científica pressupõe investimentos em investigação e desenvolvimento, a fim de alargar a base dos conhecimentos científicos em matéria de segurança dos alimentos. No âmbito do $5^{\circ}$ Programa-Quadro de Investigação são realizados projetos comunitários de I\&D sobre segurança dos alimentos, com base em programas de trabalho plurianuais. Estes programas incluem acepções indiretas (acepções a custos repartidos) e acepções diretas realizadas pelo Centro Comum de Investigação da Comissão. Os seus objetivos estão, na maior parte dos casos, direcionados para a melhoria dos conhecimentos científicos e a criação de uma base científica sólida tendo em vista a regulamentação e a definição de políticas. O $5^{\circ}$ Programa-Quadro foi orientado para uma abordagem de resolução de problemas, centrada nos cidadãos e nas suas necessidades. As acepções de investigação a realizar incidirão, designadamente, nos seguintes domínios: tecnologias alimentares avançadas, métodos de produção e distribuição alimentar mais seguros, novos métodos de avaliação em matéria de contaminação, riscos químicos e exposições a produtos químicos, o papel da alimentação na promoção da saúde e os sistemas harmonizados de análise dos produtos alimentares. Todavia, em casos específicos de detecção de um problema potencial para a saúde humana, é frequentemente necessário iniciar uma 
investigação ad hoc imediata. No momento presente, estas necessidades poderiam ser parcialmente cobertas pelo Centro Comum de Investigação da Comissão, mas o sistema em vigor deve ser dotado de flexibilidade global e dos recursos financeiros adequados para poder financiar projetos de I\&D em resposta direta a urgências alimentares. Torna-se, pois, necessário criar procedimentos orçamentais e administrativos, incluindo a revisão regular do programa de trabalho em matéria de investigação e a realização de convites à apresentação de propostas específicas, a fim de responder a desafios urgentes.

20. No âmbito do sistema de cooperação científica (Scoop) são coligidas informações científicas sobre uma vasta série de questões relacionadas com a segurança dos alimentos por instituições e organismos nacionais em toda a comunidade. A Coordenação das informações científicas no intuito de obter uma panorâmica europeia só foi assegurada num número limitado de domínios, quando em muitos casos é precisamente esta dimensão europeia que falta para fornecer as informações necessárias a uma avaliação dos riscos ao nível da UE. A definição de prioridades para a recolha de informações científicas deve ser melhorada e coordenada com o Programa de Trabalho do(s) Comitê(s) Científico(s). Devem igualmente ser adaptadas iniciativas de cooperação científica em países terceiros se for o caso.

21. Para os produtos de origem animal foi estabelecido um sistema de Laboratórios Comunitários de Referência, a fim de prestar apoio analítico especializado à Comissão e aos laboratórios dos Estados-membros. Esses laboratórios desenvolvem métodos de detecção e prestam assistência aos laboratórios dos Estados-membros na aplicação desses métodos. É necessário assegurar uma gestão central eficaz a fim de garantir que os laboratórios de referência passem a constituir uma verdadeira rede de laboratórios comunitários ao serviço da política da UE. Tendo em conta as capacidades e infraestruturas científicas do Centro Comum de Investigação, esta tarefa poderia ser-lhe confiada. Deve igualmente ser analisada a possibilidade de criar laboratórios comunitários de referência para novos domínios. A informação científica constitui a base da política de segurança dos alimentos. É óbvio que os pareceres científicos sobre a segurança dos alimentos devem ser da mais elevada qualidade. Além disso, devem ser fornecidos antecipadamente e de forma viável aos responsáveis pela tomada de decisões em matéria de proteção da saúde dos consumidores. 
22. O sistema de aconselhamento científico da Comissão foi completamente reorganizado em 1997 com base nos princípios fundamentais de excelência, transparência e independência. Atualmente os pareceres científicos são formulados por oito comitês científicos sectoriais, cinco dos quais abrangem, direta ou indiretamente, os domínios da alimentação humana e animal. Foi também criado um Comitê Científico Diretor que formula pareceres sobre as questões pluridisciplinares, a BSE, os procedimentos harmonizados de avaliação dos riscos e a coordenação das questões para as quais são competentes diversos comitês setoriais (por exemplo, a resistência antimicrobiana). Esta tarefa de coordenação é especialmente importante, uma vez que as questões de segurança dos alimentos são cada vez mais abordadas numa perspectiva de continuidade desde a exploração agrícola até à mesa. Os secretariados dos comitês são assegurados pelos serviços da Comissão. Os membros dos comitês são selecionados após a avaliação rigorosa da sua excelência científica no respectivo domínio de competência. A independência dos Membros é assegurada através da estrita aplicação das declarações de interesses.

23. Alimentação humana, alimentação animal, medidas veterinárias relacionadas com a saúde pública, plantas, saúde e bem-estar dos animais, produtos cosméticos e produtos não alimentares, medicamentos e dispositivos médicos, toxicidade, ecotoxicidade e ambiente. No âmbito do artigo $31^{\circ}$ do Tratado Euratom, foram criados grupos específicos de peritos científicos no domínio da contaminação radioativa dos alimentos para consumo humano e animal [sic]. (Comissão das Comunidades Europeias, 2000)

As metas da União Europeia são ambiciosas; a pedra basilar para seus programas de ações, hoje, são a questão ambiental, as alterações climáticas e o aquecimento do planeta; os habitats naturais e a vida selvagem; as questões de ambiente e saúde; os recursos naturais e a gestão de resíduos. Essas ações têm como objetivo melhorar a produção de alimentos e a saúde humana. Objetivam também preservar o patrimônio rural e diminuir ao máximo as populações urbanas.

Os recentes programas de ação têm refletido uma deslocação nas políticas, que passaram de um mero controle da utilização de substâncias ou produtos específicos para um inventivo à utilização de alternativas mais se- 
guras e para uma reflexão sobre o que acontece ao produto quando chega ao fim de sua vida útil (União Europeia, 2007b).

$\mathrm{Na}$ União Europeia, o meio ambiente parte do controle da agricultura para os demais fatores, e a segurança alimentar vincula-se a ambos, para, dessa forma, ajustar programas conjuntos, para si e para o comércio internacional, em que eles se envolvem ora como exportadores, ora como importadores.

O objetivo da política agrícola comum consiste em proporcionar aos agricultores um nível de vida razoável, fornecer aos consumidores alimentos de qualidade a preços adequados e preservar o patrimônio rural. A política de qualidade evoluiu de forma a satisfazer as necessidades de mudança da sociedade. Assim, a segurança alimentar, a preservação do ambiente rural, uma boa relação qualidade, o preço e a agricultura como fonte de culturas para a produção de combustíveis adquiriram uma importância crescente (idem, ibidem).

A União Europeia traz o histórico de restrição alimentar de seus países fundadores e, há cinquenta anos, estabelece o que se chama de Política Agrícola Comum (PAC), que busca subvencionar a produção de produtos alimentares de base e assegurar a autossuficiência e a segurança do aprovisionamento alimentar dentro de uma concepção ambiental. A PAC é, atualmente, a mais integrada das políticas comunitárias, absorvendo uma parte considerável do orçamento da União Europeia. São muitas as reformas realizadas, que incluem uma maior atenção à higiene, à qualidade dos alimentos e ao bem-estar animal. Inclui-se nessas mudanças a substituição das subvenções à produção, por pagamentos diretos aos agricultores, o que contribui para um comércio mundial mais justo. As técnicas agrícolas estão voltadas para as preocupações dos consumidores e para a agricultura biológica, bem como para manutenção do glamour de certos produtos originários de regiões reconhecidamente tradicionais. A rotulagem dos produtos com identificações especiais demonstra a preocupação em dar o valor agregado aos produtos rurais europeus.

Para completar o ciclo entre segurança alimentar, agricultura e meio ambiente, a União Europeia adota um plano de ajuda humanitária, cujo objetivo é prestar ajuda de urgência às vitimas de catástrofes naturais, de conflitos ou de outras circunstâncias extraordinárias semelhantes. A União Europeia (2007a) pode iniciar seu plano de ação a pedido da Comissão, de organizações não governamentais, de organizações internacionais, de um 
Estado-membro ou do país beneficiário. É necessário que as autoridades locais não tenham recursos para socorrer essas vítimas e que as ações sejam para socorro imediato, de prevenção e ações de reconstrução. Seu prazo de duração é de, no máximo, seis meses.

De conclusivo, pode-se afirmar que a União Europeia tem dado exemplo jurídico de decisões favoráveis à solidificação da segurança alimentar, em parceira com a defesa da agricultura e do meio ambiente rural. A jurisprudência do Tribunal de Justiça da Comunidade Europeia tem se voltado para a proteção da saúde e da vida das pessoas no setor alimentar. Também há constantes decisões reiteradas no sentido de que os Estados-membros estabeleçam, em determinadas condições, um procedimento de autorização prévia para os produtos alimentícios ou seus ingredientes legalmente comercializados em outros Estados-membros. Isso faz que a fiscalização fique mais intensa, porque não se restringe somente à observância das normas do Direito Comunitário. Dessa forma, há de se deduzir que corresponde a cada Estado-membro da União Europeia decidir como eliminar o obstáculo da livre circulação de mercadorias. Logicamente, essas decisões são consoantes ao Direito Comunitário e devem ser claras e precisas, objetivando, inclusive, as mudanças gerais de proteção dos particulares e a garantia de seus cumprimentos (Vaqué, 2004, p.398).

Assim, pode-se afirmar que, afora todas as medidas estabelecidas pela União Europeia, os países que a integram ainda podem estabelecer outras tantas para assegurar a segurança alimentar de seus cidadãos. As políticas públicas para esse fim estão constituídas tanto pelos países europeus como pelo bloco que as organiza. Nesses Estados de bem-estar, o acesso à alimentação tornou-se gradativamente uma garantia vinculada à condição de cidadão. Por meio da expansão da renda e do emprego, como fontes legítimas de suprimentos das necessidades básicas, combinadas ao processo de ampliação do status político do indivíduo, como membro da nação e portador de direitos, foi possível desvincular bens e benefícios sociais - entre eles a alimentação - de contribuições prévias ou da lógica estrita do mercado (Burlandy \& Magalhães, 2007).

A União Europeia é demonstração real de que a segurança alimentar é fruto da satisfação mínima de renda, trabalho, alimentação, acesso à saúde, educação, saneamento, precaução e, sobretudo, de políticas constantes dos Estados-membros, em defesa de seus cidadãos. 


\section{A segurança alimentar no Brasil}

\section{Dados sobre a situação alimentar no Brasil}

A Constituição brasileira de 1988 contempla em seu artigo $5^{\circ}$ :

Todos são iguais perante a lei, sem distinção de qualquer natureza, garantindo-se aos brasileiros e aos estrangeiros residentes no País a inviolabilidade do direito à vida, à liberdade, à igualdade, à segurança e à propriedade [...].

Não obstante, a realidade brasileira aponta: 35 milhões de pessoas com fome crônica; de cada cinco brasileiros, um passa fome; de cada três crianças, uma é desnutrida (Helene, 1995). Há, ainda, uma grande parcela da população vivendo em condições de indigência, principalmente no meio rural. Nesse setor, $50 \%$ das pessoas vivem abaixo da linha da pobreza. Também aí se encontram os mais elevados índices de desnutrição infantil. Situação ainda mais crítica é a dos trabalhadores rurais sem terra. Estima-se que no País existam 4,8 milhões de famílias sem terra para viver e trabalhar. Há também a situação dos pequenos agricultores que, mesmo possuindo terra, não dispõem das condições mínimas necessárias para gerar o sustento de suas famílias (Fórum Brasileiro de Segurança..., 2007a).

O mapa da fome, elaborado pelo Ipea em 1993, revelou a fome e a indigência de 32 milhões de brasileiros; o dado para calcular essa situação levou em conta a pessoa cuja renda familiar mensal fosse correspondente, no mínimo, ao valor da aquisição de uma cesta básica de alimentos, que atendesse aos requerimentos nutricionais recomendados pela $\mathrm{FAO} / \mathrm{ONU}$ e OMS.

A sociedade brasileira convive com a existência das doenças associadas à pobreza e à exclusão, tais como a fome e a desnutrição, e aquelas associadas a hábitos alimentares inadequados que afetam mais gravemente as populações pobres, mas que atingem duramente todas as outras parcelas da sociedade. Ninguém está imune às distorções impostas pelo paradigma do desenvolvimento dominante (Valente, 2002a, p.39).

A Organização Mundial de Saúde, em seu último relatório, apontou o Brasil com uma disparidade regional chocante e uma falta de reformas sociais, o que leva à caracterização da desnutrição brasileira como umas das maiores causas de mortes no País, principalmente das crianças. Aponta, como for- 
ma de diminuir esse problema, as garantias de empregos e a construção de infraestrutura para saneamento básico (Castellon \& Tarantino, 2002, p.50).

Os últimos dados do Instituto Brasileiro de Geografia e Estatística (IBGE) computam 14 milhões de pessoas que, pelo menos um dia em 2004, passaram fome. A pesquisa que levou em conta os problemas de insegurança alimentar e sua manifestação mais severa, a fome, foi aplicada em todo o território nacional e demonstrou que, no Norte e Nordeste brasileiros, mais de $60 \%$ das pessoas revelaram ser habitual ou eventual a insuficiência de alimentos, o que comprovou as grandes desigualdades existentes no Brasil, já que foi estimado que na região Sul a mesma situação contemplava 30\% (IBGE, 2006, p.148). Os 13 milhões de pessoas vulneráveis à fome representam menos de um terço dos 44 milhões usados como base para implementação do Programa Fome Zero. Para a economista Lena Lavinas (apud Gomide, 2006), da Universidade Federal do Rio de Janeiro (UFRJ), os 72 milhões de pessoas em insegurança alimentar mostram que o contingente de pessoas abaixo da linha de indigência, sem dinheiro para consumir uma dieta de 2.200 calorias diárias, é superior ao estimado pelo governo.

Os mais atingidos pela fome, em proporcionalidade, são os negros: $52,3 \%$ deles residem em domicílios sob o risco de conviver com a fome, enquanto $28 \%$ dos brancos são atingidos pelo problema. Tal desigualdade afeta também as mulheres e a população mais jovem. Nos lares chefiados por mulheres, há uma insegurança alimentar na faixa de 22,9\% contra 17,3\% naqueles coordenados por homens. A mesma pesquisa demonstra nitidamente que a fome deriva da falta de rendimentos, de emprego, de condições estruturais.

As doenças que provocam as causas da morte na infância são as parasitárias e infecciosas e as doenças do aparelho respiratório, resultantes de um estado físico deplorável da criança, pela ausência ou má qualidade dos alimentos. A (não) qualidade da água é provocadora de $89 \%$ das doenças e $65 \%$ das internações hospitalares; $90 \%$ dos domicílios no meio rural não têm serviço de saneamento; $82 \%$ das pessoas com renda até dois salários mínimos não têm coleta de esgoto (Melo, 2005, p.7).

No Maranhão, ocorreram 33 casos de mortes por beribéri ${ }^{8}$ em 19 municípios, num verdadeiro quadro de violação aos direitos humanos à alimen-

8 Beribéri é uma doença neurológica, causada pela falta de ingestão de vitamina B1 encontrada em grãos integrais, verduras e carnes. Os sintomas são dormência e inchaço nas pernas, dificuldade de caminhar e fraqueza, que evolui para insuficiência respiratória e cardíaca. Quando tratada, não é mortal. 
tação adequada e à saúde. O relatório elaborado e encaminhado à ONU, em novembro de 2006, registrou que a violação dos direitos humanos se dá, primeiramente, quanto à organização da sociedade, na exclusão de terra e na falta de trabalho - tudo o que leva uma população ao risco de ter uma dieta monótona. Num segundo momento, a violação é decorrente de um sistema de saúde incapaz de detectar esses casos com rapidez suficiente para evitar tais mortes e de distribuir o remédio a tempo (Freire, 2006).

O Maranhão foi o estado onde se registrou maior índice de fome. É a região com maiores problemas do Nordeste, onde o meio rural é a área mais atingida pela miséria: $17,1 \%$ da população contra $13 \%$ das cidades, contrariamente do ocorrido nas regiões Sul, Sudeste e Centro-Oeste, onde a maior miséria está nas periferias das cidades, embora haja a proximidade dos índices na região Sul - 3,9\% na cidade contra 2,6 no campo; CentroOeste $-5,2 \%$ na cidade contra $4,2 \%$ no campo; Sudeste $-4,1 \%$ na cidade contra 3,8\% no campo. De acordo com os técnicos do IBGE (2006, p.28), isso ocorre por causa da boa estrutura agrícola nas regiões Sul, Sudeste e Centro-Oeste, e da pobreza concentrada em locais sem serviços adequados nas áreas urbanas.

Mais uma vez, entrelaçam-se os direitos à alimentação e à saúde com o direito ao meio ambiente saudável.

De acordo com Bernardes (2005, p.A16):

[...] ficou ressaltado que Manari, no estado de Pernambuco, ocupa o último lugar no ranking que mede o índice de desenvolvimento humano (IDH), com taxa igual ao do país do Caribe e foi citada no relatório das Nações Unidas sobre os bolsões da miséria brasileira. A cidade não tem esgoto sanitário, tem renda média de $\mathrm{R} \$ 70,00$ por família. Tem 13.500 habitantes, a taxa de analfabetismo é de 80\%, 2,9 anos é a média de permanência de crianças e adolescentes na escola. Lindacy, com 9 filhos é uma das moradoras desta cidade, vive exclusivamente dos R \$ 95,00 recebidos do Bolsa Família. Josivania está grávida e não tem nenhuma fonte de renda. "Às vezes sinto que vou desmaiar de tanta fome." Vive da caridade pública. Isaura de 60 anos implora: "queria que os poderosos dessem um jeito na miséria".

Os indígenas do Mato Grosso do Sul, guarani-caiovás, perderam suas terras e acampam em acostamentos com crianças esquálidas, com doenças respiratórias provocadas pela inalação constante da poeira das estradas. 
Ainda conforme levantamento regional, 136 índios morreram por falta de atendimento médico, fome e desleixo do poder público. As estatísticas incluem a morte de 86 crianças, das quais 32 eram índios de Mato Grosso. O número de suicídios cresceu, em 2005, para 29, e a causa está relacionada à desagregação cultural, resultado da interminável disputa por terra com o branco grileiro, que age como se dono fosse dela (Mendes, 2006).

Outras situações poderiam ser descritas sobre a miséria brasileira. Nos capítulos precedentes, tratou-se do trabalho escravo, do trabalho infantil, das condições degradantes de trabalho - todos decorrentes do estado de miséria que esses trabalhadores se encontram - dos danos ambientais que provocam a miséria e vice-versa, e da luta pela terra que mata, tira a dignidade e ainda não faz justiça.

Outra reportagem, no entanto, informa que o dono da fazenda mais cara do Brasil pede $\mathrm{R} \$ 420$ milhões por suas terras, que ocupam um espaço maior que a cidade de São Paulo, com 100 mil cabeças de gado (Attuch \& Paiva, 2005).

Muitas são as matérias jornalísticas que enaltecem o agronegócio brasileiro e que veem nele a salvação para o fim da miséria brasileira. As recentes notícias sobre transgênicos chegam a apontar que a introdução desse processo no Brasil seria um dos mecanismos para o fim da fome, uma vez que a produção atingiria recordes de safras suficientes para alimentar toda a população, considerando que as safras de soja e milho fossem repletas de sucesso. Fica a grande interrogação: o brasileiro pobre ou miserável para ter acesso a esses produtos teria de comprar e compraria com o quê, se o problema maior é renda? Ainda que o produto ficasse altamente barato (o que é uma ilusão), não existe o hábito de se comer soja no Brasil. Poderia se chegar ao desplante de não saber devidamente aproveitar o grão. Com o milho seria a mesma coisa. Onde buscar renda para comprá-lo? Poderia o brasileiro se alimentar exclusivamente de milho e seus derivados? Isso revelaria uma segurança alimentar?

Martins (1996, p.109) afirma de forma categórica que a existência de fome no Brasil não é efetivamente um problema de insuficiência de produção de alimentos. A grande limitação está, decididamente, no acesso ao alimento que, colocado no mercado, é apenas acessível a quem disponha de renda.

Esses vendedores de ilusão e seus discursos sobre o fim da fome no Brasil não merecem consideração. Fazem o discurso das multinacionais e não 
estabelecem parâmetros para mensurar os reais e verdadeiros problemas da fome e desnutrição que estão no Brasil desde a colonização. Ademais, a produção de grande quantidade de alimentos em um país não é condição suficiente, nem necessária, para evitar que parte da população passe fome.

O paternalismo brasileiro é protetor de riquezas e perverso com a pobreza. O rico desconta a atenção à saúde no imposto de renda, uma forma de subsídio pelo Estado. O pobre não tem garantido o seu acesso à saúde pública, ficando sujeito a seu voto em troca de atenção. As perversidades praticadas em nome da filantropia reiteram a exclusão social e necessitam ser rompidas. (Lins, 2007)

No Brasil, é mais fácil ocupar-se da insegurança alimentar, da luta contra a fome, dos programas contra a miséria, da reforma agrária, da agricultura familiar, do que propriamente tratar dos temas "segurança alimentar", "nutrição" e "saúde pública". A abordagem tem de ser efetivada sob a ótica da exclusão social - problema maior -, para, aos poucos, ir construindo o raciocínio ainda imaturo das políticas públicas propiciadoras de metas de redução da fome, desnutrição e doenças derivadas da miséria.

Observa-se, no Brasil, que os quadros já descritos de miséria e desigualdade são resultados de práticas derivadas da trajetória de exclusão, clientelismo e autoritarismo que marcou a nação e foi responsável pela baixa eficácia simbólica da linguagem dos direitos de cidadania (Telles apud Ramalho \& Martins, 1994, p.73). Além disso, a corrupção, o assistencialismo, o corporativismo e o baixíssimo controle social agravaram os quadros dos direitos humanos básicos no Brasil. Somente a partir de 1988, emergiu, junto com o clamor público, advindo de movimentos sociais, organizações não governamentais e de políticas públicas de idealistas, a luta pela segurança alimentar, muito embora a fome e a preocupação com os alimentos já tivessem sido pauta de outras tantas discussões.

\section{A elaboração de um conceito de segurança alimentar no Brasil}

Segurança alimentar nunca se desvinculou da batalha para vencer a fome no Brasil. Também sempre esteve aliada à luta pela democracia e pela justiça social e econômica. 
A história das carências alimentares e nutricionais inicia-se na colonização, com a escravidão dos índios que morriam em cativeiro porque se recusavam a comer enquanto estivessem escravizados. Os negros, conforme descrito por Boris Fausto (2002, p.26), não duravam mais que 25 anos, porque, além dos maus-tratos, a alimentação era deficitária tanto em caloria como em quantidade. Estende-se por todo o período da República, sempre atingindo de forma cruel o meio rural. Ao longo dos anos, com a intensa migração urbana associada à industrialização acelerada e ao processo de modernização conservadora da agricultura, a situação agravou-se, chegando aos dias de hoje com os quadros já descritos de milhões de pessoas em situação crítica de penúria. Pode-se afirmar que são 500 anos de fome e de carências nutricionais, aliadas, hoje, ao problema de obesidade, sobrepeso e complicações decorrentes de alimentação inadequada, como hipertensão arterial, osteoartrose, intolerância a glicose, diabetes mellitus, dislipidemia, diferentes tipos de câncer e doenças cardiovasculares. A hipertensão arterial assumiu o primeiro lugar como causa mortis proporcional desde a década de 1990 (Valente, 2002a, p.43).

De uma maneira que causa espanto, os esforços acadêmicos para garantir e estudar a segurança alimentar não brotam nos direitos humanos. São as outras ciências, como a Economia, a Sociologia, a Medicina, a Nutrição, que se dedicam com afinco a melhorar esse quadro lamentável. Só muito recentemente os estudos jurídicos - em sua maioria em nível internacional e outros raríssimos compêndios nacionais - trazem a fome tratada como direito à alimentação.

O problema da alimentação e nutrição deveria ser de responsabilidade da sociedade e não somente de cada cidadão. A sociedade já desenvolveu a capacidade de organização empresarial para resolver, sem muitas dificuldades, o problema da produção de alimentos; existe dinheiro para os investimentos necessários, inclusive preservando o princípio da lucratividade; a tecnologia é mais que disponível e a terra existe em abundância; resta a solidariedade para encontrar a solução para a fome.

Sposati (1996, p.190-3) critica a universidade e o direito na construção da segurança alimentar:

Dizemos é de direito. É de cidadania, mas do ponto de vista da consolidação efetiva desses direitos há um campo a construir. Quanto nós, na condição 
de membros da Universidade, estamos atentos à produção de um paradigma científico que contenha uma centralidade na questão da efetivação dos direitos da cidadania? Assim, é preciso pensar que a segurança alimentar ou a insegurança alimentar nasce do patamar da ética na política. Quando trazemos isto para a universidade, é preciso pensar que há fome de alimento, há exclusão de educação e conhecimento, o que recai na questão do emprego, na questão da geração de renda e da cultura. A fome é, portanto, resultante de uma questão amplamente complexa do processo de exclusão social, portanto é uma questão de democracia social, democracia econômica, política e democracia do acesso ao conhecimento.

Assim, o espaço da universidade deveria se ocupar de uma forma mais contundente do tema, nos mais diferentes setores, pois, no fundo e de uma forma genérica, a fome ou a produção de alimentos perpassa pelos setores tecnológicos, biológicos e, sobretudo, das ciências humanas.

Os debates acalorados sobre a fome tiveram seu início em 1930 quando Josué de Castro 9 escreveu seu primeiro ensaio denunciando a extensão e a gravidade da fome no Brasil e o silêncio com que isso era tratado pela elite brasileira. ${ }^{10}$ Castro identificou que a fome era um fenômeno socialmente determinado que, portanto, requeria soluções sociais e políticas, e não somente técnicas.

À época, o tema era considerado tão sensível politicamente, em plena ditadura, que foi trocada a palavra fome pelo termo má nutrição, em uma tentativa de ocultar a dimensão social e política da fome. Pessoas que se atreviam a usar a palavra fome eram vistas como subversivas (Valente et al., 2007, p.151).

Mais tarde, o grande apogeu da obra de Josué de Castro foi Geografia da fome, em 1946, em que continuava a afirmar o silêncio sobre a fome, como

9 Josué de Castro, pernambucano, era sociólogo e médico. Escreveu diversos trabalhos sobre o tema "fome". Foi presidente do Conselho da Organização de Alimentação e Agricultura das Nações Unidas (FAO) em 1952 e 1956. Foi fundador da Associação Mundial para o Combate à Fome. Em 1960, foi nomeado embaixador do Brasil na ONU. Em 1964, foi cassado pela ditadura militar, tendo morrido no exílio, em 1973, na França.

10 Aliás, é muito comum observar esse não enxergar dos problemas sociais por parte das classes mais altas, que vivem suas realidades, não se importando com as misérias dos que as rodeiam. Passam a considerar ou notar as dificuldades dos mais pobres quando se sentem ameaçados em suas seguranças físicas ou jurídicas. 
se este fosse um tema proibido. Esse autor entendia o problema da alimentação como um complexo de manifestações simultaneamente biológicas, econômicas e sociais. Nessa obra, abordou a questão da fome que ele chamou de "coletiva parcial" - por causa da falta permanente de determinados elementos nutritivos nos hábitos regulares de alimentação - mais do que a fome total, ou inanição, que se manifesta nas áreas de miséria extrema (Maluf, 2007, p.79). A indignação de Castro versava sobre o fato de o Brasil estar se desenvolvendo e não estar se preocupando com a miséria. A ignorância dos fundamentos da ciência da alimentação, o que resultou na má aplicação da escassa disponibilidade financeira e, por fim, na composição de uma dieta alimentar imprópria, tornou-se a grande crítica desse autor que se firmou como o grande ícone da segurança alimentar no Brasil. Cristóvão Buarque (2002, p.12), a respeito de Josué de Castro, manifestou-se, dizendo que:

A ele deve o sentimento de que o desenvolvimento econômico tanto em seu desenho como no modo de implantação, não é capaz de atender às necessidades de todos. A idéia que prevalecia até Josué de Castro e que eu também defendia era a que a industrialização gerava riqueza, a riqueza se espalhava e todos teriam dinheiro para comprar comida e tudo mais que fosse necessário. O mérito de Josué não se restringe em ter denunciado a fome, mas em mostrar que a sua existência é sintoma do próprio tipo de desenvolvimento. Os textos marxistas e socialistas diziam que o problema da fome estava na distribuição, em decorrência da propriedade privada dos meios de produção. Josué de Castro, aparentemente atrás dos socialistas, mas na verdade bem à frente deles, criticou o próprio modelo de civilização e, não apenas o sistema capitalista.

Em paralelo, há de se comentar que a ausência de reforma agrária e mesmo de uma legislação agrária que fortalecesse o pequeno proprietário, junto com a crescente concentração da propriedade, foi uma das maiores causas da falta de segurança alimentar. A elaboração do Estatuto da Terra, em 1964, não aliviou a crise da produção de alimentos da cesta básica, a empregabilidade, o acesso à terra para que as pessoas não migrassem. Desse Estatuto, é preciso lembrar que mereceu êxito a parte da política agrícola que beneficiava, em sua maioria, os grandes proprietários. Os poucos assentamentos não surtiram o efeito esperado, já que os recursos alocados eram tímidos, e, ainda, conforme Zibetti (2004, p.137): 
[...] o assentamento provoca a quebra da monocultura com preocupação de produzir produtos da cesta básica e introdução da biodiversidade, ampliando a cadeia agroalimentar e um agribusiness diversificado de interesse do consumidor nacional e até internacional.

Lembra Zibetti (2004, p.137-8) que o produto agrícola, em especial a cesta básica, não pode ser tratado como mera mercadoria ou bem de mercado, mas como um bem social e de interesse coletivo. No entanto, no Brasil, não se priorizou o interesse coletivo, e a terra foi considerada uma riqueza de poucos, destinada à instalação da monocultura de exportação, com ênfase ao latifúndio e com políticas agrícolas para esses grandes proprietários, deixando à deriva os pequenos e médios proprietários, exatamente aqueles que alimentam o País.

Outras causas contribuíram para a falta de estrutura da segurança alimentar. A preocupação em firmar a cidadania formal é vista como uma base para não se atingir a melhoria de vida.

A exclusão dos escravos, das mulheres, dos analfabetos, períodos longos de ditadura ou de participação limitada na vida pública foram alguns óbices à vigência plena das formas liberais de democracia. A falta de políticas públicas compensatórias e assistenciais fez com que grandes parcelas da população deixassem de se integrar no mercado como trabalhador regular e formalmente assalariado, com capacidade de consumo e de alguma mobilidade social. (Lopes, 2002, p.86)

Assim o Brasil caminhou, deixando de construir políticas públicas, deixando de investir no setor social, depreciando o meio agrário, provocando um agravamento na pobreza a qual foi se alastrando até as regiões mais ricas, pois a migração rural foi construindo as periferias e fortalecendo os bolsões da miséria das grandes cidades.

Na década de 1970, os chamados planos de desenvolvimento trataram, inicialmente, da política agropecuária com os incentivos fiscais, a disseminação do uso de insumos - Revolução Verde - e com a pesquisa agropecuária (1972-1974). O segundo plano (1975-1979) voltou-se para a reforma agrária e a redistribuição de terras no Nordeste, cujos resultados foram inexpressivos. Na vigência do segundo plano, registra-se a criação do Pro- 
grama de Alimentação do Trabalhador (PAT) e do Programa de Abastecimento de Alimentos Básicos (Proab).

No início da década de 1980, foi retomada a questão da segurança alimentar, junto com a redemocratização. Os movimentos sociais ganham força. Surge o Movimento contra a Carestia e contra a Fome, ao lado da criação de Sindicatos de Trabalhadores Independentes, do Movimento dos Sem Terra e do Movimento pela Anistia dos Opositores ao Regime Militar, que mais tarde, transformou-se no Movimento Nacional pelos Direitos Humanos.

As primeiras referências ao conceito de segurança alimentar no Brasil, em nível documental, surgem no Ministério da Agricultura, no final de 1985, em meio ao crescimento da mobilização da sociedade. Foi criado um Conselho Nacional de Segurança Alimentar, dirigido pelo presidente da República e composto por ministros de Estado e representantes da sociedade civil, para atender às necessidades alimentares da população e atingir a autossuficiência nacional na produção de alimentos. Foi a semente plantada que deu impulso, em 1986, à primeira Conferência Nacional de Alimentação e Nutrição, onde o tema foi discutido e se aprofundou o debate.

A Constituição de 1988 converteu todos os direitos consagrados na Declaração Universal dos Direitos Humanos das Nações Unidas em direitos legais e instituiu uma série de mecanismos processuais, que buscam dar a eles eficácia. Mas, a essa época, já estava consolidada a tremenda desigualdade à qual Jessé Souza (2006) atribui a ausência de responsabilidade social, a falta de limitar e regular o mercado que produz riquezas e simultaneamente miséria, sofrimento e desespero para aqueles que não logram se adaptar aos seus imperativos.

Garantir com certeza os direitos constitucionais exige, conforme Maria Helena Rodrigues (2007, p.120), que os compromissos históricos e as promessas emancipatórias saiam do papel e da mera retórica, para se ter a oportunidade de construir um país mais democrático. O Ministério das Relações Exteriores, em 1996, posicionou-se no sentido de que o acesso à alimentação é um direito em si mesmo, na medida em que a alimentação constitui-se no próprio direito à vida. Negar esse direito é, antes de mais nada, negar a primeira condição para a cidadania, que é a própria vida; daí ser o direito à alimentação um direito humano básico que, com os demais 
direitos prolatados no artigo $5^{\circ}$ da $\mathrm{CF}$, integra o rol das garantias e dos direitos fundamentais do ordenamento jurídico brasileiro.

Ressalta-se que o movimento começou com a participação do Estado e da sociedade civil e com a pressão dos movimentos sociais. Em 1991, o governo paralelo do Partido dos Trabalhadores elaborou a proposta da segurança alimentar que foi enviada ao então presidente Collor, que a engavetou.

No governo de Itamar Franco, foi reapresentada a proposta que foi recebida pelo governo. Em 1993, criou-se o Conselho Nacional de Segurança Alimentar (Consea), integrado por 8 ministros e 21 membros da sociedade civil. O Consea foi resultado de um processo de negociação entre o Movimento pela Ética na Política e o governo de Itamar. Posteriormente, o movimento optou pelo combate prioritário a outro tipo de corrupção e lançou as primeiras sementes da Ação pela Cidadania, contra a Fome, a Miséria e pela Vida, que será o grande parceiro civil no Consea. Esse movimento teve à frente um dos maiores batalhadores pelo fim da fome: Herbert de Souza, o Betinho, que, até sua morte, se vinculou à luta pelo fim da fome e se tornou um dos ícones do movimento. O governo federal reconheceu, nesse ano, a situação de miséria e fome que desencadeia a violência e definiu seu enfrentamento como prioridade do governo (Valente, 2002a, p.46). O mapa da fome elaborado nessa época revelou que mais da metade dos pobres estava nas cidades; então, a prefeitura de São Paulo realizou um seminário chamado "Fome: o desafio dos anos 90".

Em 1994, foi realizada a $1^{a}$ Conferência Nacional de Segurança Alimentar, cujo relatório final refletiu a preocupação do povo brasileiro com a concentração de renda e de terra, e esses dois fatores foram apontados como as determinantes da fome e da miséria no País. Também foram abordados pontos para algumas diretrizes para as políticas públicas definidas nos seguintes eixos:

- Eixo 1: reduzir os custos dos alimentos e seu peso no orçamento familiar;

- Eixo 2: assegurar saúde, alimentação e nutrição a grupos populacionais determinados;

- Eixo 3: assegurar a qualidade biológica, sanitária, nutricional e tecnológica dos alimentos e seu aproveitamento, estimulando práticas alimentares e estilo de vida saudáveis. 
Com essa base, estruturou-se o conceito brasileiro de segurança alimentar:

[...] segurança alimentar e nutricional é a realização do direito de todos ao acesso regular e permanente a alimentos de qualidade, em quantidade suficiente, sem comprometer o acesso a outras necessidades essenciais, tendo como base práticas alimentares promotoras de saúde, que respeitem a diversidade cultural e que sejam social, econômica e ambientalmente sustentáveis. (cf. Maluf, 2007, p.17)

A experiência do Consea representou dois aspectos fundamentais: o reconhecimento do problema da fome e da miséria na agenda política brasileira, tanto por parte do governo quanto da sociedade civil, e a experiência efetiva da parceria entre esses dois segmentos, para o enfrentamento da questão. A ação da cidadania definiu como prioridade a geração de emprego e renda, a democratização da terra, o assentamento dos produtores rurais, o combate à desnutrição materno-infantil, o fortalecimento, ampliação e descentralização do Programa Nacional de Alimentação Escolar, a continuidade da utilização de estoques públicos para os programas de alimentação social e a revisão do Programa de Alimentação do Trabalhador.

No governo Fernando Henrique, o Consea foi substituído pelo Conselho da Comunidade Solidária, também ligado à Presidência da República. A estratégia adotada pelo Conselho da Comunidade Solidária pretendia combater a fome e a pobreza por meio de um plano de estabilização econômica, priorizando programas e não construindo políticas (Maluf, 2007, p.85). Um dos maiores entraves entre o Comunidade Solidária e a sociedade civil, na discussão da fome, repousava nas controvérsias sobre o papel do comércio internacional, a condução da política econômica e os rumos da reforma agrária (Ipea, 1996, p.16).

Em 1998, as entidades da sociedade civil novamente se reuniram no Fórum Brasileiro de Segurança Alimentar e Nutricional para discutir a fome, e, desde essa época, esse núcleo assumiu um papel significativo na condução da mobilização social a favor do fim da fome. O FBSAN tem cumprido papel decisivo na mobilização social e no avanço das discussões sobre o tema. ${ }^{11}$

11 O FBSAN, com seu site e rede de informes, muito auxiliou na construção deste trabalho, fornecendo material, enviando dados por e-mail. Reúne e promove encontros com prefeituras, participou da reconstrução do Consea e criou várias diretrizes aprovadas na II Conferência Nacional de Segurança Alimentar e Nutricional. 
A partir do governo Lula, estabeleceu-se o Projeto Fome Zero, uma política nacional de segurança alimentar para o Brasil, lançado pelo Instituo da Cidadania em 2001. A experiência acumulada e a mobilização social foram parceiras para atacar as regiões de pobreza extrema com meta de três refeições por dia. Mobilizou, na esfera administrativa, a recriação do Consea e a criação de um Ministério Extraordinário de Segurança Alimentar e Combate à Fome. A primeira providência foi a criação de um cartão para dar acesso à suplementação de renda das famílias pobres. Esse programa atingiu as regiões do semiárido, destinando $\mathrm{R} \$ 50,00$ para famílias com renda per capita mensal inferior a meio salário mínimo. Nesse contexto, $46,1 \%$ dos beneficiados eram famílias do meio rural.

O Fome Zero foi construído sobre um tripé: ações estruturais voltadas para as causas mais profundas da fome e da pobreza, ações específicas para atender diretamente as famílias que não se alimentam adequadamente e ações locais implantadas pelas prefeituras municipais e pela sociedade civil. O Fome Zero, para Maluf(2007, p.92), assumiu um perfil de mutirão nacional contra a fome e com os objetivos de criar a participação da sociedade civil e organizar doações de dinheiro e alimentos. Essa mobilização social confluiu em grande medida para o atual talher nacional de mobilização social e educação cidadã do Fome Zero e seus correspondentes estaduais, dedicados a constituir uma rede nacional de educadores populares e agente locais de segurança alimentar, atuando junto às famílias atendidas pelo programa.

O programa Fome Zero foi substituído, em 2003, pelo Bolsa Família, Lei ${ }^{\circ}$ 10.836/2004, que unificou todos os programas sociais. ${ }^{12}$ O objetivo do governo é assegurar o poder de compra dos beneficiários e garantir que o programa continue cumprindo seu papel na redução da pobreza do País. Conforme dados da Rede de Informação e Ação pelo Direito a se Alimentar (Fian Brasil), em outubro de 2006, o Bolsa Família alcançou sua meta, atingindo 11,2 milhões de brasileiros tidos como miseráveis e pobres. $\mathrm{O}$

12 O Bolsa Família é um programa de transferência de renda que distribui aos seus beneficiários um valor fixo de $\mathrm{R} \$ 50,00$, para famílias com renda mensal de até $\mathrm{R} \$ 60,00$, por pessoa, tenham elas prole ou não. Pagam-se, também, até R\$15,00, por criança de 0-15 anos, num limite de três, o que computa um limite máximo de $\mathrm{R} \$ 95,00$ por família. Para as que têm renda superior a $R \$ 60,00$ e menor ou igual a $R \$ 120,00$, por indivíduo, fica somente o auxílio de $\mathrm{R} \$ 15,00$. Em 18 de julho de 2007, foi publicado o Decreto ${ }^{\circ} 6.157$ que reajustou os valores do Bolsa Família para $\mathrm{R} \$ 58,00$ e o benefício variável para $\mathrm{R} \$ 18,00$, com teto máximo de $\mathrm{R} \$ 112,00$. 
alcance dessa meta rendeu ao presidente Lula, apesar de diversos escândalos de corrupção, a reeleição, em outubro de 2006, com ampla vantagem sobre seu concorrente. Pela primeira vez na história do Brasil, a introdução de direitos sociais resultou na eleição de um presidente da República (Zimmermann, 2007b, p.37).

O Bolsa Família é um programa com condicionantes. Exigem-se comprovação da pobreza, acompanhamento de saúde e do estado nutricional das famílias, frequência à escola e acesso à educação alimentar. A exigência de condicionantes tem apoio do Banco Mundial, que vê nessas ações um novo tipo de assistência social. Porém, pondera que essas políticas de transferência de renda devem ser por um curto período, enquanto as condicionantes investem em capital humano de longo prazo.

Jessé Souza (2006, p.J5), sobre o programa Bolsa Família, avaliou que

[...] o mesmo, como todos os programas sociais feitos no Brasil, são assistencialistas, porque obedecem à lógica do curto prazo. Tratam os indivíduos como se todos tivessem os mesmos comportamentos, disposições fungíveis e intercambiáveis. Vem daí ideia que a pobreza é um caso fortuito e casual; uma pequena ajuda econômica faz a pessoa levantar e caminhar com sua próprias pernas. Assim, se cria a ilusão de uma sociedade sem classes, na medida que pertencemos ao mesmo tipo humano. Assim, nos tornamos efetivamente incapazes de pensar ações de médio e longo prazo para incluir de fato classes sociais que se reproduzem há séculos como excluídos. Não é culpa do governo nem do presidente; é a versão pública de um narcisismo primitivo que nos faz ver que o problema está sempre nos outros e não em nós mesmos.

\section{Feliciello \& Garcia (1996, p.221) afirmam que}

[...] ações de combate à fome e à miséria construídas à custa de doações várias ou contribuições estatais são episódicas e inconstantes, que responsabiliza o conjunto da sociedade pela satisfação imediata dos pobres. Este assistencialismo não cria consciência crítica sobre os mecanismos de produção e miséria e acentua o reconhecimento caritativo dos pobres em relação aos indivíduos e às agências assistenciais. Não cria condições para o crescimento da cidadania, mas sim da gratidão que poderá se transformar em voto eleitoral no momento adequado ou em reafirmação de desigualdades sociais, cabendo aos pobres aguardar a benevolência dos mais poderosos. 
Em termos numéricos, pode-se dizer que o Bolsa Família apresenta bons resultados de melhoria alimentar (outras opções de alimentos foram introduzidas à dieta, como arroz, verduras e carne, já que antes a alimentação era feijão e farinha), dinamização da economia local (em cidades pobres, há um aumento de mercados, casas comerciais) e diminuição da pobreza (estudos da Fundação Getulio Vargas comprovam que o índice caiu de 28,2\% de brasileiros em pobreza absoluta para 22,7\%). O "Ipea chegou à conclusão de que o Bolsa Família individualmente é responsável por 21\% da queda da desigualdade medida pelo índice Gini" (Fórum Brasileiro de Segurança..., 2007b). ${ }^{13}$ Segundo o Ministério do Desenvolvimento Social e Combate à Fome (MDS), o programa atende, hoje, 11,1 milhões de famílias em todo o Brasil e, além de contribuir para a redução da pobreza e da desigualdade, tem melhorado a situação alimentar e nutricional dos beneficiários, em função das exigências de que os pais mantenham as crianças na escola e cumpram alguns cuidados básicos para a saúde da família.

Apesar de seu caráter imediatista, e partindo do jargão "Quem tem fome tem pressa”, o Bolsa Família apresentou resultados práticos de diminuição de fome, porém é amplamente criticado na sua essência, porque é limitante a um número de famílias em cada município, além de não se constituir num direito, mas pertencer ao grupo da seletividade, o que gera possibilidades de privilégios e desvio, o que já aconteceu e foi divulgado pela mídia. Não sendo um direito, não se pode dizer que o programa cumpra direitos humanos previstos constitucionalmente. Tendo condicionantes, o Estado tem de oferecer a efetividade do cumprimento dessas metas. Devem existir escolas, postos de saúde e meios de as pessoas chegarem até eles - o que não acontece a contento. $\mathrm{O}$ valor atribuído é baixo e não atende às necessidades mínimas, o que não garante o acesso à alimentação adequada. A comprovação da pobreza, numa perspectiva de direitos humanos, é vexatória e humilhante, e seu controle, deficitário. Algo a ser tomado em conta é que esse programa contribui para o que a Fian denomina como "armadilha da pobreza".

13 Criado pelo matemático italiano Conrado Gini, é um instrumento para medir o grau de concentração de renda em determinado grupo. Ele aponta a diferença entre os rendimentos dos mais pobres e dos mais ricos. Numericamente, varia de zero a um (alguns apresentam de zero a cem). O valor zero representa a situação de igualdade, ou seja, todos têm a mesma renda. O valor um (ou cem) está no extremo oposto, isto é, uma só pessoa detém toda a riqueza. $\mathrm{Na}$ prática, o índice de Gini costuma comparar os 20\% mais pobres com os $20 \%$ mais ricos. 
Se o beneficiário trabalha e aumenta sua renda, ele perde o Bolsa Família. Pesquisadores apontam que esse programa do Banco Mundial está muito mais preocupado com a inclusão e exclusão, e focaliza os pobres. Segundo Rawlings (apud Zimmermann, 2007b, p.44):

Mecanismos de focalização da pobreza podem mais eficientemente promover canais de alcance dos pobres, minimizando os erros de inclusão e exclusão, mas essas eficiências têm que ser balanceadas contra o crescimento dos custos administrativos e outros problemas associados com a focalização, incluindo possibilidades de corrupção por parte dos funcionários públicos.

Na verdade, as críticas ao Bolsa Família são múltiplas, mesmo com seu sentido de atender rapidamente quem está na miséria. O Programa da Renda Básica de Cidadania é visto, inclusive pela Fian, como a melhor alternativa, que deveria ser implementada paulatinamente, focando primeiramente as crianças e os adolescentes. Lavinas (2004) propõe que a quantia seja de $\mathrm{R} \$ 80,00$ para cada criança até 16 anos, o que, aos poucos, eliminaria a pobreza dessa classe, mais vulnerável e pobre. De acordo com Suplicy (2006), a renda básica poderia ser introduzida passo a passo, até 2010. Em sua opinião, o Bolsa Família é o primeiro passo. A proposta de Suplicy é que cada pessoa comece recebendo $\mathrm{R} \$ 40,00$ - o que parece ser pouco, mas, numa família de cinco pessoas, isso significaria $\mathrm{R} \$ 200,00$ a mais, quantia esta superior à do Bolsa Família. Lavinas (2004) ainda defende que a renda básica seria um direito, aplicado a um determinado grupo, sem seleção. $\mathrm{O}$ valor deveria ser proporcional ao da cesta básica, eliminaria custos de fiscalização, evitaria humilhações, manteria as populações tradicionais em suas comunidades (quilombolas, indígenas, povos da floresta) e ainda combinaria a atividade produtiva com o acesso ao programa.

Para a Fian, o maior paradoxo é que a maioria das organizações da sociedade civil demonstra não possuir grande empolgação pela introdução da renda básica de cidadania. Melhor dizendo, a sociedade civil brasileira ainda não entendeu o verdadeiro significado dos direitos sociais (Zimmermann, 2007b, p.48).

Na verdade, o Bolsa Família representa uma estratégia para resolver o problema imediato dos que têm fome, mas jamais pode ser visto como a única proposta para a segurança alimentar no País. Esta atende uma par- 
cela daqueles que são considerados no nível da indigência. Há os pobres que comem, mas comem mal e não na quantidade suficiente e adequada. Portanto, a segurança alimentar compreende muito mais que o socorro a um determinado grupo, que carece de recursos imediatos. Assim, tem-se uma série de outros instrumentos que conjuntamente devem funcionar, de forma harmônica, numa política ambiciosa de mudança na estrutura social.

Outros programas sociais governamentais estão dirigidos ao combate à fome e à pobreza, por exemplo:

- Saúde: Sistema de Vigilância Alimentar e Nutricional e Combates às Doenças, Sistema Nacional de Vigilância Sanitária, Programa de Saúde da Família e outros.

- Educação: Programa Nacional de Alimentação Escolar.

- Agricultura: Compra direta de pequenos produtores, Programa de Atendimentos Institucionais e Programa Venda em Balcão.

- Desenvolvimento Agrário: Programa Nacional de Reforma Agrária, Programa de Assentamentos e Desenvolvimento Sustentável e Programa Nacional de Fortalecimento da Agricultura Familiar.

- Trabalho e Emprego: Programa de Alimentação ao Trabalhador, Erradicação ao Trabalho Escravo e Degradante, Programa de Geração de Renda e Plano Nacional de Qualificação Profissional.

- Previdência e Assistência Social: Programa de Erradicação do Trabalho Infantil.

Alguns desses programas também apresentam problemas, pois o que eles oferecem de auxílio, na visão das famílias, não é suficiente. É o caso do Programa de Erradicação do Trabalho Infantil (Peti) que paga R \$ 25,00 por mês, na zona rural, e $\mathrm{R} \$ 40,00$, na zona urbana, o que leva as famílias a vacilarem sobre a inclusão, ou não, de seus filhos no programa, tendo em conta que, muitas vezes, o trabalho dessas crianças (embora ilegal e degradante) rende mais que o recebido. E vale lembrar que, para quem não tem o que comer, quaisquer dez reais a mais tornam-se a verba do pão semanal. É o que narram as reportagens sobre o tema, a seguir trazidas. Na Bahia, o menino de 14 anos, que corta lenha, recebe, por mês, $R$ \$ 50,00; nas casas de seus vizinhos, a cena repete-se, envolvendo crianças de até 6 anos. Perto de Belo Horizonte, em Santa Rita de Ouro Preto, as crianças pedem para que os pais as incluam no Peti, por causa dos jogos e das brincadeiras, mas os 
pais recusam-se, porque elas podem render muito mais que o recebido no programa, ajudando a transportar, cortar e trabalhar a pedra sabão, usada no artesanato local. Para além da ajuda financeira, há a crença de que pôr os filhos para trabalhar é também educá-los. Essa é uma visão generalizada no Brasil. ${ }^{14}$ Outras famílias utilizam-se do dinheiro vindo do programa e ainda colocam seus filhos no trabalho, muitas vezes, feito dentro de casa, para que os vizinhos não as entreguem às autoridades do Peti (Sant'anna, 2006a).

No quadro de transferência de renda, há os programas ligados à Previdência Social e que atendem aos direitos sociais estabelecidos na Constituição de 1988. São:

- Transferir, mensalmente e de forma permanente, um salário mínimo para pessoas idosas e portadoras de necessidades especiais e para carentes com renda familiar per capita de até um quarto de salário mínimo e em cujas famílias não se receba outro benefício da Previdência Social.

- Transferir, mensalmente e de forma permanente, um salário mínimo para pessoas idosas, viúvas, em licença, em recuperação de acidente de trabalho ou doentes, na condição de Segurados Especiais da Previdência Social, isto é que tenham trabalhado em atividades rurais em regime de economia familiar.

O Bolsa Família entra nesse quadro de transferência de renda.

Gasques (2002, p.168-9) relata, ainda, outros programas de ordem municipal e estadual e também outras experiências de associações da comunidade, igreja e organizações não governamentais que demonstram que muitas iniciativas e ações diversas vêm se desenvolvendo para os objetivos propostos de combate à fome. Algumas são temporárias: campanhas de Natal; dia das crianças; suspensão de ICMS para baratear produtos como leite e trigo, no estado de São Paulo; ações municipais de incentivos à agricultura; Pastoral da Criança. Esta última, sob o comando da Dra. Zilda Arns, promove a melhoria da saúde, tira as crianças da desnutrição e promove o

14 A socióloga Isa de Oliveira, secretária executiva do Fórum Nacional de Erradicação do Trabalho Infantil, afirma que, principalmente no interior, parcela significativa da população não tem a informação suficiente para entender a importância do direito de ir à escola, de brincar, de ter infância. Há uma cultura de que a criança é um objeto e o adulto tem direitos sobre ela (cf. Sant'anna, 2006b). 
aleitamento infantil, entre tantos outros trabalhos voluntários que ficam no silêncio, mas aliviam sobremaneira a dor da fome de muitos. ${ }^{15}$

Graças a todos esses incentivos, à diminuição da fome no Brasil e a outras políticas públicas que serão comentadas adiante, 8 milhões de brasileiros deixaram a baixa renda para integrar a classe C, que, em 2005, era de 62,7 milhões de habitantes, saltando para 66,7 milhões de brasileiros em fins de 2006. O poder de compra dessas pessoas melhorou, e o Nordeste foi apontado pela pesquisa como o maior polo de crescimento da renda média familiar: a alta foi de 38\%, e as intenções na compra de computador e da casa própria foram os itens mais contemplados (Chiara, 2007).

Ainda nas inter-relações de melhora de vida, diminuição da pobreza e, consequentemente, melhoria na sustentabilidade alimentar, têm-se outros índices que revelam que a desigualdade social caiu, mas que o trabalho infantil cresceu: um mercado ilegal, com maior concentração no campo; ao todo, 2,5 milhões de jovens estão trabalhando. E, ainda, há mais lares com telefone do que com rede esgoto - resultado claro da privatização da telefonia e da morosidade do poder público em definir as políticas de saneamento (Irany \& Rodrigues, 2006).

Mais pessoas estão empregadas, mas os salários são cada vez menores. Para Ricardo Paes de Barros (apud Dantas, 2007, p.B7), do Ipea, "A nossa redução na pobreza e na desigualdade foi fantástica, mas é preciso limitar a celebração". É difícil pensar em uma queda sustentável da pobreza e da desigualdade que não venha acompanhada de uma melhora generalizada dos postos de trabalho. Os trabalhadores de baixa qualificação foram os que passaram por melhorias. São eles de pequenas cidades, trabalhadores ligados à agropecuária. O que Barros sinaliza é que essas melhorias de aumento de renda e baixa salarial podem ser advindas dos programas de transferência de renda, do aumento de aposentadorias nas famílias e aumento de pessoas trabalhando.

O que não se pode dizer é que os gastos obtidos nessas melhorias estão sendo revertidos para uma alimentação saudável e adequada. Ademais, as melhorias registradas são tímidas, a pobreza não foi vencida, a desnutrição

15 Hoje, o trabalho de Zilda Arns está espalhado em mais de 42 mil comunidades espalhadas nas regiões pobres, as mais pobres, com 270 mil voluntários. Essa franquia de solidariedade é requisitada em todo o mundo e já atua na América Latina, África e Ásia. O próximo na lista de espera é o Haiti. (Manir, 2006). 
não foi domada e o consumo revelado traz o ranço de hábitos cultivados durante anos de má alimentação aliados à vontade de obtenção de outros bens de consumo como eletrônicos, roupas e eletrodomésticos, em substituição a uma alimentação farta, diversificada e rica em vitaminas e nutrientes. Como já apontado, a população pobre muitas vezes se encanta com o "progresso" e opta por este, em detrimento da segurança alimentar.

Ademais, outros problemas estão surgindo na órbita alimentar. A má alimentação resulta na obesidade e nos seus altos custos para o sistema de saúde, uma outra preocupação para o setor público, que terá investir muito mais na prevenção e orientação dos hábitos alimentares, formulando dietas e modificações, inclusive culturais. Sichieri \& Nascimento (2007, p.101) concluíram que a obesidade, em si, de forma direta, não causa tantos gastos, mas as decorrências das doenças advindas dela significam não só gastos hospitalares, mas a manutenção de medicamentos diuturnamente e, ainda, o pagamento dos constantes afastamentos de trabalhadores que, obesos, apresentam problemas de hipertensão, coluna, diabetes, acidente vascular cerebral (AVC) e infartos do miocárdio. Afora a preocupação econômica, o substancial reside na qualidade de vida do indivíduo e no seu sofrimento e de sua família, e, quando pobre, obviamente, agrava-se o quadro, transtornando toda estrutura doméstica.

Os hábitos alimentares das classes mais altas também têm se alterado. É cada vez maior o número de pessoas que se alimentam fora de casa, fazem dietas ou se alimentam de produtos industrializados, o que exige maior fiscalização do Estado. Sem tratar da questão da produção, que será vista no setor de políticas públicas.

Em termos de melhorias na ordem administrativa, o retorno do Consea representou a ativação da programação nacional de melhorias e discussões tanto em nível nacional como interestadual e municipal. Suas recomendações, celebradas em 2004, influenciaram, a posteriori, a formulação da Lei de Segurança Alimentar.

Diferentes fóruns de discussão vêm recomendando as seguintes medidas como estratégias para monitorar a realização do Direito Humano à Alimentação:

- Definir de forma compartilhada pelo governo e sociedade os conceitos básicos sobre fome, desnutrição, pobreza, além de indicadores de mensuração e 
acompanhamento (constituindo uma base de dados e sistema de monitoramento), metas e prazos para a realização progressiva dos direitos em questão.

- Incluir a temática da alimentação como um dos direitos humanos nos diferentes espaços de formação educacional e de pesquisa.

- Implementar mecanismos jurídicos para a defesa dos direitos humanos econômicos, sociais e culturais.

- Instituir um sistema de auditoria e corregedoria nos programas oficiais e um sistema nacional de proteção dos denunciantes, além de implementar mecanismos de captação de denúncias (como o disque-denúncia).

- Constituir organismos públicos, com total independência do Estado, capazes de monitorar a realização do Direito, de investigar as denúncias de violações e de apresentar recomendações no sentido de sua superação.

- Universalizar de fato o acesso aos programas sociais, bem como o acesso a informações sobre direitos, critérios de elegibilidade em programas sociais, mecanismos de denúncias etc., de forma a incluir grupos que atualmente estão excluídos desses direitos.

- Instituir a notificação obrigatória da desnutrição.

- Sensibilização e integração do Poder Judiciário e dos seus agentes ao tema.

- Monitorar o processo decisório, analisando em que medida os princípios do direito humano são considerados pelos atores, sejam eles do Executivo, Judiciário ou Legislativo, ao tomarem as decisões de alcance público.

- Implementar medidas que garantam que decisões públicas sobre terras que envolvam deslocamento populacional sejam antecedidas de um relatório de impacto social, ou seja, uma análise das possíveis consequências sobre a situação social da população.

- Identificar as atribuições dos diferentes níveis de governo - federal, estadual e municipal -, os mecanismos de acesso e as responsabilidades relativas às ações de promoção, proteção e garantia do Direito Humano à Alimentação.

- Estabelecer uma estratégia de políticas públicas para garantia do Direito Humano à Alimentação com definição clara de metas, prazos e a alocação de recursos.

- Monitorar políticas e acordos internacionais que tenham repercussão direta em questões estratégias para o campo da SAN, como acesso a alimentos e água, identificando em que medida ferem o Direito Humano à Alimentação.

- Fortalecer o controle social e promover a formação continuada dos atores sociais que integram mecanismos de controle social (como os conselhos) no campo dos Direitos Humanos, formação que deve se estender aos demais 
atores que participam desse processo, como trabalhadores do setor público e privado, e a sociedade em geral.

- Ampliar o acesso da sociedade civil às decisões sobre a distribuição dos recursos públicos. (Conselho Nacional de Segurança..., 2007)

Daí se extrai o comprometimento do Direito com a questão da segurança alimentar, fato até então pouco trabalhado. O Brasil, como signatário do Pacto dos Direitos Econômicos, Sociais e Culturais, não tem como refutar o previsto no sentido de que cada Estado-parte tem uma obrigação mínima de assegurar a satisfação de, pelo menos, níveis mínimos essenciais de cada um dos direitos.

Assim, por exemplo, um Estado-parte no qual um número significativo de indivíduos esteja privado de uma alimentação adequada, de cuidados médicos essenciais de abrigo e moradia ou das formas mais básicas de educação está, prima facie, descumprindo as obrigações contidas no Pacto. (Piovezan, 2007, p.29)

O envolvimento do Poder Judiciário torna-se vital, assim como a participação do Ministério Público, nas investigações das apurações das violações. Sobre a questão da justiciabilidade do direito humano à alimentação, Valente et al. (2007, p.173) manifestam-se, afirmando que o problema é de ordem ideológica e política.

Os setores Judiciário e Executivo do governo não têm problemas em defender os direitos econômicos de bancos e empresas privadas falidas, alocando bilhões de dólares em reparações ou subsídios às mesmas. Isto é visto como uma coisa natural a ser feita para preservar a estabilidade econômica, preservar empregos, entre outras justificativas. Porém, discutir a justiciabilidade ou mesmo a exigibilidade econômica dos DHESC dos setores mais pobres da sociedade, violados pela implementação ou falta de políticas públicas é visto como fora de pauta, e uma desnecessária interferência do Judiciário, no reino do Executivo.

Para Cançado Trindade (apud Piovezan, 2007, p.29):

Há que se garantir a justiciabilidade dos direitos econômicos e sociais, a começar pelo princípio da não discriminação. Por que motivo em relação aos 
direitos políticos são há muito condenadas práticas discriminatórias, as quais em relação aos direitos econômicos e sociais persistem e parecem ser toleradas como supostas realidades lamentáveis e inevitáveis? Há que submeter à justiciabilidade decisões governamentais e de organismos financeiros internacionais que, à guisa de resolver problemas econômicos, condenam ao empobrecimento, ao desemprego e à fome, se não a médio prazo ou longo prazo, à miséria e à morte, milhares de seres humanos. Se é certo que a vigência de muitos direitos econômicos e sociais é de realização progressiva, também é certo que tal vigência requer medidas imediatas por parte dos Estados, certas obrigações mínimas em relação a um núcleo de direitos de subsistência (direitos à alimentação, à moradia, à saúde, à educação, somados ao direito ao trabalho) quanto pouco para neutralizar os efeitos devastadores das políticas recessivas particularmente sobre os segmentos mais carentes ou vulneráveis da população.

Valente et al. (2007, p.173) entendem que as ações judiciais devem ser os últimos recursos, e os instrumentos administrativos e quase judiciais devem ter prioridade. Na opinião desses autores, as funções administrativas devem ser exercidas pelos órgãos federais, estaduais e municipais, pelo Consea, pela Comissão de Monitoramento de Violações de DHAA, pelo Conselho de Defesa dos Direitos de Pessoa Humana (CDDPH) e similares, e pela realização de audiências públicas em parceria com o Ministério Público, incluindo a elaboração de termos de ajuste de conduta (TAC).

Nos informes do Relatório Nacional do DHAA, há apontamentos que registram que 40 casos de denúncias foram investigados por esta comissão que, em parceria com o Ministério Público estadual e federal, promoveu visitas que resultaram em solução dos problemas vivenciados, em sua maioria, na área rural, por trabalhadores sem terra, quilombolas, seringueiros, indígenas, atingidos por barragem e que as providências foram tomadas por meio de termos de ajuste de conduta, audiência pública e ação civil pública. ${ }^{16}$

Beurlen \& Fonseca (2007, p.178-9), ao tratarem da justiciabilidade do direito humano, lembram o Comentário Geral n 12 do Comitê dos Direitos Econômicos, Sociais e Culturais que estabelece que

16 Relatório do DHAA disponível em: <http://www.planalto.gov.br/consea.dhaabrasil. pdf>. Acesso em: 27 jan. 2007. 
[...] qualquer pessoa que seja vítima de violação do direito humano à alimentação adequada deveria ter acesso a efetivos remédios judiciais, ou de outra natureza, tanto em nível internacional, quanto nacional. Todas as vítimas de tais violações têm direito a reparações adequadas, as quais podem ter forma de restituição, compensação, satisfação ou garantia de não repetição.

Os autores comentam que os contrários à justiciabilidade dos direitos econômicos, sociais e culturais são os que continuam na lógica liberal, aduzindo que apenas ao Poder Executivo e ao Legislativo, nas suas atribuições, cabe definir quais as políticas públicas que devem ser criadas, em que ritmo e quanto se pode gastar para a realização de direitos por meio das referidas políticas, posto que o Poder Judiciário não está democraticamente legitimado para tanto.

Christopher Golay (apud Beurlen \& Fonseca, 2007, p.178), com extrema clareza, contrapõe-se, afirmando que de forma alguma a exigibilidade judicial dos direitos econômicos, sociais e culturais violaria o equilíbrio entre os poderes, pois cabe a todos os poderes do Estado garantir que as obrigações estatais relacionadas a tais direitos sejam cumpridas, inclusive no que diz respeito à destinação orçamentária.

Essa opinião é compartilhada neste trabalho e ainda é fundamentada em Langford, que diz que a demora do Poder Judiciário em agir em defesa dos grupos vulneráveis sub-representados deriva da sua falta de poder político (Beurlen \& Fonseca, 2007, p.178).

No mundo, há várias decisões a favor da alimentação adequada, e, no Brasil, essa postura ainda é tímida, mas o Supremo Tribunal Federal (STF) e o Superior Tribunal de Justiça (STJ) vêm agindo a favor de pessoas que carecem de medicamentos especiais (STJ: RESP 335171, RESP 138583/ SC; STF: RE241630/RS), situações especiais de carência a evidenciar-se o princípio da solidariedade social (STF Recl. 2319MC/RS), e, em decisão monocrática, o ministro Celso de Mello chega mesmo a criticar a forma como o argumento da "reserva do possível" vem sendo utilizado no Poder Judiciário brasileiro e reconhece a legitimidade deste para controlar a constitucionalidade de políticas públicas, notadamente em casos de omissão do Poder Executivo (ADPF45DF - sendo importante ressaltar que tal decisão extinguiu o feito sem resolução do mérito, em razão da perda superveniente do objeto) (idem, p.181). 
As posições de enfrentamento do Judiciário serão mais audaciosas à medida que a sociedade se envolver na questão e as universidades despertarem seus alunos, futuros juízes, para uma discussão aprofundada sobre a efetivação dos direitos humanos.

O Ministério Público, tanto federal quanto estadual, deve trabalhar numa união de esforços, uma vez que, como é dito por Beurlen \& Fonseca "a miséria e a fome são locais, enquanto o dinheiro é federal". Ademais, deve fiscalizar os órgãos públicos envolvidos no âmbito federal e estadual, abrir inquéritos civis, quando provocados, manter conversas com os dirigentes dos diversos conselhos, promover reuniões e debates com os gestores municipais, promover audiências públicas e celebrar ajustes de condutas.

A construção jurídica do direito à alimentação adequada, afora todo instrumental já aqui apontado, ganhou um novo mecanismo no Brasil. No âmbito legislativo, foi aprovada a Lei n ${ }^{\circ} 11.346$, de 15 de setembro de 2006. Essa lei cria o Sistema Nacional de Segurança Alimentar e Nutricional (Sisan), com vistas a assegurar o direito humano à alimentação adequada e dá outras providências. Este foi um grande passo, pois consagrou o direito humano à alimentação e abriu a possibilidade de qualquer cidadão, desprovido desse direito, cobrar do Estado medidas que corrijam essa situação. ${ }^{17}$

O sistema estabelecido pela lei cria as condições para a formulação da política e do plano nacional nessa área, com diretrizes, metas e recursos, instrumentos de avaliação e monitoramento, composto de ações e programas integrados, envolvendo diferentes setores de governo e a sociedade na busca pela alimentação suficiente e de qualidade para todos.

Os diferentes programas hoje existentes pertencentes a três alçadas públicas, em simbiose com o setor privado, com pouco diálogo e articulação entre si, poderão, doravante, agir conjuntamente. Por exemplo, a merenda escolar poderá ser fornecida pelos produtores locais, assim como o Bolsa Família poderá ser efetivado pela vigilância alimentar e nutricional. Os órgãos criados na lei serão de caráter permanente, e a Lei de Segurança Alimentar deixa de ser política de governo para tornar-se política de Estado.

17 Entende-se que o cidadão já poderia cobrar do Estado esse direito pelas razões apresentadas, porém era bem mais difícil. Com a legislação em vigor, espera-se que os procedimentos fiquem mais ágeis. 
É sabido que o fato de existir uma lei não significa sua eficácia, porém trata-se de um grande passo na luta dos que acreditam que a fome pode ser superada neste País. Entretanto, outros obstáculos terão de ser vencidos.

Como ficou demonstrado ao longo deste capítulo, a segurança alimentar é um direito que urge em ser respeitado. Realiza-se por meio de políticas públicas, de colaboração internacional e de participação da sociedade civil. Assume relevância o cumprimento de leis que a ele se refiram. Sua eficácia depende de orçamento público, que precisa estar comprometido com os relegados à extrema pobreza. A justiciabilidade é mister para sua realização. A cidadania não combina com a desigualdade social.

No Brasil, a desigualdade social tem o amparo da indiferença. Indiferença que advém daqueles que não sentem as dores da fome e da humilhação. O direito não pode compactuar com a miséria, não pode ser refém dos grupos de elite. A luta pelos direitos sociais e pelo direito humano à alimentação deve coincidir com o direito de não ter medo, e, segundo Riobaldo, personagem de Guimarães Rosa (2006), esse é o maior direito de todos nós. 


\section{4 \\ Das interfaces entre o Direito Agrário, OS DIREITOS HUMANOS E A SEGURANÇA ALIMENTAR NO BRASIL}

Do exposto até então, pode-se afirmar que o meio rural foi tema constante, quer como cenário de produtividade, quer como local de violações de direitos humanos, quer como meio de superar a insegurança alimentar. No cenário internacional, o meio rural tem sido preservado. Uma das recomendações da União Europeia acena para tal. No Brasil, os produtos advindos do mundo agrário são os responsáveis pelo sucesso da balança comercial, mas, simultaneamente, o mundo rural ocupa a estatística do grande vilão, detentor da miséria da desnutrição e da fome.

Um dos primeiros passos para se combater a pobreza no Brasil é mudar o entendimento do que é pobreza e compreender seu caráter multifacetário. Com todos os recursos que o Brasil desfruta no meio rural, deveria ser três vezes menor o índice de pobres. Para inverter esse quadro, devem ser mudadas as relações de poder que fortalecem o autoritarismo, o clientelismo, o patrimonialismo, a corrupção e as novas formas neoliberais de apropriação privada dos recursos públicos, e é preciso caminhar em sentido da prosperidade, da qualidade de vida, da justiça social e do acesso aos serviços por todos os cidadãos (Barbosa, 2006).

Os paradoxos agrários apresentam no universo jurídico personagens que ora são heróis, sujeitos capazes de produzir e resolver problemas alimentares; atores que, com seus métodos sustentáveis e técnicas, podem reduzir os desastres ecológicos; personagens que, com suas habilidades, movem meios de produção capazes de diminuir a fome e, ainda, propiciar a realização da alimentação adequada. 
No mesmo meio rural, há, contudo, pobreza, indigência e falta de alimentos; há danos ambientais irreversíveis, destruição de paisagens e bens naturais, poluição de águas e desemprego; há muita produção de grãos, que não alimentam quem os produz; muita cana para alimentar automóveis, enquanto faltam carne, verduras e arroz na mesa dos pobres. E na mesa dos outros, alimentos, mas nem sempre a preços reais e nem sempre com qualidade. Mas, na mesa dos ricos, certamente, estarão os produtos orgânicos, as carnes nobres, o café de exportação, o azeite virgem, as frutas selecionadas - tudo administrado por uma boa nutricionista, que zela pela saúde destes.

A desigualdade social no meio rural, de raízes históricas, é a responsável pela insegurança alimentar, pelas violações do direito à alimentação adequada, pela migração rural, pelo inchaço das cidades, pela violência urbana, pela destruição ambiental, pela miséria, pela baixa estima do brasileiro, que se envergonha de sua ruralidade.

Desigualdade não se afina com democracia. Um dos grandes obstáculos para implementar a democracia real na América Latina e, acredita-se, também no Brasil, no dizer de Boaventura Sousa Santos (2004) é o fato de que

A sociedade latino-americana é politicamente democrática, mas socialmente fascista. A democracia é tutelada, distanciada da população, para que se justifiquem as vantagens de poucos. Politicamente, os processos democráticos se caracterizam pela exclusão, de um lado, e pela trivialização, do outro; ou seja, no cotidiano, a já pequena participação popular se dá em torno de questões menores, levando a um distanciamento da política que por si só gera conformismo. Ou seja, é a institucionalização da resignação.

Por consequência, o que se tem é uma democracia de baixíssima intensidade, quadro que só se alterará com uma mudança radical na redistribuição dos recursos e se o mercado interiorizar os custos sociais e ambientais do processo produtivo comercial, o que afeta profundamente o meio rural, que merece ser revisto com desvelo.

O meio rural, com suas facetas, pode ser salvador ou perdição. Seu destino e sua condução implicam escolhas da humanidade, representada pelos Estados, pelos blocos econômicos e pela sociedade civil, a qual, por sua vez, é representada pelos empresários, pelos movimentos sociais, pelas pessoas 
como um todo que zelam pelos direitos humanos. Por mais que a tecnologia avance, que os computadores dominem o mundo e a educação, que a capacidade laboratorial crie sementes capazes de triplicar a produção, a terra ainda não foi superada na sua finalidade de alimentar os seres. Os bens naturais que ela detém, se destruídos, poderão ficar definitivamente perdidos ou terão de ser recuperados para a manutenção do planeta.

A sustentabilidade, acompanhada ou não do termo desenvolvimento, vem sendo aproveitada em diferentes setores da sociedade civil. Traz uma noção fértil e essencial para questionar mais do que o desenvolvimento, o estilo de sociedade ocidental /moderna / capitalista, no qual o Brasil de forma periférica se insere. (Silva, C., 2001, p.14)

Nesse raciocínio, a agricultura representa muito mais que um meio para produzir alimentos, significa que o modelo escolhido para sua condução é o resultado de uma política para melhorar, ou não, o mundo. A condução das políticas rurais implica a manutenção, ou não, da biodiversidade, das riquezas culturais, das identidades rurais e das opções políticas democráticas.

Não há como desvincular meio rural, direitos humanos e segurança alimentar. Essa trilogia desencadeia-se em ramificações que perpassam por meio ambiente, políticas públicas, modelos econômicos e direitos econômicos, sociais e culturais, que se interligam à paz e à solidariedade. Percorre a totalidade dos direitos humanos, mescla-se às concepções das atividades agrárias reguladas nas constituições, nos tratados e nas legislações esparsas, envolvendo organismos públicos, privados e a sociedade como um todo.

Os modelos escolhidos pelos Estados e sua opções a favor, ou não, do meio rural são determinantes para os resultados da existência, ou não, da pobreza. A desconcentração de terra, o comércio internacional, a elaboração de uma agenda política voltada para os pobres e excluídos, a articulação entre a economia local e a política globalizada, o abastecimento alimentar, a reforma agrária, a agricultura familiar, a vigilância sanitária, o controle dos consumidores, o meio ambiente sustentável, as pesquisas científicas são exemplos de mecanismos viáveis para uma segurança alimentar.

O Direito, presente em todos os setores, deve estar se interligando à Economia, à Sociologia para, assim, construir soluções mais eficazes. O Direito Agrário apresenta-se como o fio condutor desse processo. Seu uso é 
vinculado às políticas determinadas nos objetivos constitucionais de cada país ou às normas comuns das agendas comunitárias. Porém, pode ser alterado se os agentes sociais entenderem que as políticas públicas não atendem ao bem comum. No meio das incertezas, o debate sobre a segurança alimentar abriga discordâncias sobre a capacidade das sociedades modernas de atingir o ideal da sustentabilidade plena. No entanto, não se podem tolerar os níveis mínimos em que grande parte das pessoas vive, num mundo onde a produção alimentar está aquém de insuficiente. Crescimento não significa desenvolvimento. Na agricultura brasileira, este é o retrato fiel da afirmação. A agricultura cresceu, bateu recordes de produtividade e mesmo o grande produtor não se sente recompensado por tal fato. As safras foram recordes, mas os lucros foram menores, porque a complexidade do crescimento/desenvolvimento envolve diferentes variáveis.

Para haver desenvolvimento, devem ser removidas as principais barreiras às liberdades. Consiste em remover, no dizer de Veiga (2006b, p.136),

[...] tudo o que limita as escolhas e as oportunidades das pessoas. O crescimento econômico obviamente pode ser muito importante como um meio de expandir as liberdades desfrutadas pelos membros de uma sociedade. Mas, as liberdades também dependem de muitos outros determinantes, como os serviços de educação e saúde, ou os direitos civis.

Em muitos países, o meio rural está submetido ao subdesenvolvimento que rouba das pessoas a liberdade de saciar a fome, de obter uma nutrição satisfatória ou o remédio para doenças curáveis, a possibilidade de ter acesso à água tratada ou ao saneamento básico. Em outros casos, a privação da liberdade vincula-se estreitamente à carência de serviços públicos e de assistência social (idem, p.137).

Como já salientado, o problema da fome no Brasil não se deve à pouca disponibilidade global de alimentos, mas à pobreza de grande parte da população.

É verdade que um processo relativamente rápido de aumento de poder aquisitivo dessa população pobre levaria ao aumento da demanda por alimentos, o qual possivelmente se manifestaria como uma crise de abastecimento, pois a oferta não poderia se ajustar à demanda em curto prazo. Nesse caso, o 
aumento do preço dos alimentos iria anular, em parte, o aumento da renda daquela população. (Hoffman, 2006)

Dizer que uma pessoa passa fome porque não tem poder aquisitivo para comprar alimentos é, obviamente, uma analise muito limitada. Por que o rendimento da pessoa é baixo? Está desempregada? Mas não possui segurodesemprego? Não pode produzir seu próprio alimento? Para entender por que uma pessoa passa fome, Sen (apud Hoffman, 2006) defende que sejam analisados os direitos dessa pessoa, num enfoque mais abrangente do que considerar seu poder aquisitivo. $\mathrm{O}$ pequeno produtor pode produzir parte de sua alimentação, se tiver o direito de explorar determinada área de terra e, também, se tiver instrumentos, sementes etc. O barbeiro autônomo, com seus instrumentos de trabalho, pode obter, por meio da prestação de seus serviços, rendimento suficiente para comprar os alimentos de que necessita, entretanto ele poderá passar privações se uma mudança repentina nos costumes reduzir drasticamente a demanda de seus serviços. O presidiário tem direito às refeições fornecidas no presídio. $\mathrm{O}$ aluno de muitas escolas públicas tem direito à merenda escolar. Verifica-se, portanto, que o enfoque dos direitos das pessoas para compreender o porquê de, eventualmente, passarem fome envolve uma análise da estrutura jurídica, social e econômica da sociedade.

Pobreza e desigualdade são males independentes. No Brasil, o mais frequente é que a elevação de renda reduza a pobreza e aumente as disparidades entre pobres e ricos, assim como entre mulheres e homens, brancos e negros, rurais e urbanos. Muitas são as variáveis que formam um conjunto de regras formais e informais que vão da Constituição ao mais simples costume ou tradição, passando é claro pela distribuição dos direitos de propriedade ou pela transferência de renda, operadas por todas as esferas governamentais. A desigualdade só é vencida quando existe uma grande ofensiva social. (Veiga, 2005, p.16-8)

Os direitos das pessoas, em especial dos pobres, e a democratização dos serviços, como saúde, educação e habitação, são mecanismos para uma vida saudável. Em especial, analisar-se-ão as melhorias no setor rural, local certeiramente mais violado e, ademais, pelo fato de ser o gerador da produção alimentar. 
A agricultura é a principal atividade econômica que incide diretamente sobre as possibilidades, para superar os enormes desafios sociais enfrentados pelo meio rural. A agricultura constitui um elo fundamental dentro das cadeias agroalimentares. O Direito Agrário, instrumento de justiça social, aliado aos direitos humanos, pode construir políticas conjuntas para, de uma forma mais célere, combater a pobreza e a desnutrição. Entretanto, o Direito, muitas vezes, deve ser pressionado, e a colaboração dos movimentos sociais é mister para as mudanças. O Direito Agrário é agente de mudança, principalmente porque está aliado ao pluralismo jurídico. Seus instrumentos modificam conceitos clássicos, alteram mecanismos tidos como verdades, e suas posições incomodam os menos ortodoxos. Ver o Direito Agrário sob outra forma é negar seus princípios de justiça social. Assim, pois, dessa forma será aqui tratado.

A opção por centrar no meio rural a questão da segurança alimentar brota do cerne de que as políticas públicas voltadas para a terra consolidam a melhoria de uma gama de relações que envolvem os pobres, a miséria, o desemprego, o trabalho degradante no meio rural. Esses instrumentos poderão dar novos contornos para a estruturação de um campo mais justo, capaz de se autossustentar, capaz de gerar alimentos em quantidade e qualidade, oferecendo progresso para os seus e para as comunidades locais.

\section{O papel do Estado no setor agrícola}

Pelo demonstrado até então, reforça-se a ideia de que o setor agrícola deve merecer proteção jurídica, pela razão de ser o motor do desenvolvimento da perpetuação da espécie. Esse seria um grande motivo para justificar a importância a ele atribuída. A proteção do Direito Agrário estende-se sobre a terra e sobre o seu trabalhador e, portanto, seu caráter protetor. Quando se diz “terra”, entendem-se todas as mazelas delas advindas, como a produção e a comercialização dos produtos oriundos dela. Os mecanismos de apoio, como o crédito rural para plantio, irrigação, formação de cooperativas, políticas educacionais de manejo, enfim, a proteção à agricultura deve ser revestida de política agrícola que permita, por meio dos ditames legais, uma efetivação dos institutos jurídicos de acesso e manutenção do homem na terra, favorecendo a produção e a distribuição de riquezas. Assim, polí- 
tica fundiária e política agrícola integram-se, não podendo ser tratados os institutos sem associação, a não ser para fins didáticos.

Por suas características, o setor agrícola é, em todos os países avançados ou não, um "setor sustentado" pelo Estado, e é a sociedade, como um todo, quem paga o preço desse sustento. É isto, efetivamente, o que significa uma política para a agricultura: a definição sobre que estímulos oferecer, a quem, para que a sociedade atinja seus objetivos, isto é, o progresso e o bem-estar (Wanderley, 1996, p.267). A definição dos beneficiados da política agrícola é uma opção estatal, que revela sua preocupação com a segurança alimentar de seu povo, ou não.

Quando um país privilegia a agricultura, com certeza, seu povo não sofre, conforme ensina Ditto José Santos (2000, p.32): “os Estados que investem na estrutura agrária de um país, corrigindo suas imperfeições e investindo em políticas agrícolas, com certeza aumentam sua produção, realizam a justiça social e protegem o meio ambiente".

A agricultura, sob o ponto de vista de Carrozza (1988, p.33), representa a totalidade das atividades agrárias, e, quando se usa a expressão "agricultura”, está-se a referir à produtividade rural, por força da relação de agrariedade. Esse é o pensamento europeu e, até mesmo, americano.

No Brasil, vê-se que o termo "agricultura", embora usado, às vezes, como genérico, causa certa estranheza quando a atividade agrária está voltada para a pecuária, o extrativismo, as atividades granjeiras ou qualquer outra atividade. A ideia do "agro" refere-se, em toda extensão, à caça, à pesca, à extração que, desde os primórdios, foram atividades reguladas, em princípio, pela comunidade e, posteriormente, pela lei agrária.

Os contrastes no Brasil são evidentes na agricultura: existem áreas com alta tecnologia de clonagem de eucalipto, café e laranja, e variedades de soja de alto rendimento, irrigação de pivô central, enquanto, em outras situações, convive-se com tecnologia do século XIX.

Importante é que os Estados, ao regularem as atividades agrárias, ajustem-se às atividades locais, criando leis agrárias que considerem a produtividade, e se adaptem às necessidades regionais e imediatas de seu povo. É preciso internacionalizar a ideia de que a agricultura não é um setor da produção industrial, mas um meio de vida (Madeley, 2003, p.28).

O modelo adotado pelos Estados para a condução de suas políticas de financiamento, incentivo e acesso à terra deve ser conduzido visando ao in- 
teresse público, já que o elemento volitivo do Direito Agrário se perfaz na natureza jurídica pública e social. Essas políticas públicas são condizentes com os direitos humanos indivisíveis e complementares, integram os direitos sociais e asseguram as condições para o exercício dos direitos civis e políticos (Ramos, 2002, p.261).

Se há fraqueza por parte do Estado, que não gera o reconhecimento dos direitos mínimos, cujo denominador comum é a miséria, abre-se para a responsabilidade internacional do Estado, por violação de direitos sociais, que deve expor as omissões e fraquezas desse mesmo Estado e obrigá-lo a executar as políticas públicas necessárias à correta implementação daqueles direitos. Isso faz que se entenda que uma agricultura tem importância para uma realidade, à medida que todos ganham com ela, e não só um grupo de pessoas que, tirando da terra seus lucros, sacrificam uma série de outros indivíduos que, com trabalhos penosos e insalubres, mal comem o que produzem ou nem têm acesso a uma alimentação razoável. As normas jurídicas de proteção à agricultura devem ser coincidentes com a de proteção ao homem, devem vir ao encontro dos interesses da comunidade onde atuam e, sobretudo, devem respeitar o meio ambiente.

As conclusões dos trabalhos que sustentarão as leis devem ter conotação social, conforme ensina Ditto José Santos (2000, p.33), caso contrário, serão conclusões e ordenamentos frios que não trarão benefícios para a comunidade, mas para um grupo de privilegiados que continuarão a distorcer o real significado do Direito Agrário.

Nesse contexto, as normas agrárias devem ser buscadas no princípio da primazia da realidade, do fato social. Deve o legislador caminhar na sociedade e verificar como devem ser atendidas as necessidades do campo: deve ser feito um planejamento para o crédito rural; o acompanhamento do plantio deve ser constante; o estudo da venda do produto deve ser previamente planejado; o estudo das condições do solo e climáticas deve estar presente. A lei não pode ser posta sem esses norteadores. Os sujeitos que receberão os benefícios dos empréstimos devem ser analisados como agentes sociais propulsores da responsabilidade de promover o bem-estar de todos. As normas para a agricultura, vistas no sentido lato, não podem ser feitas para o atendimento de grupos que se autoprivilegiam.

No Brasil, isso acontece como fato corriqueiro. A anistia das dívidas dos usineiros nordestinos, dos plantadores de soja do Centro-Oeste, a prote- 
ção à propriedade produtiva, independentemente do fato de ela cumprir função social; a compra e venda de terras, em vez da desapropriação; a lei de permissão das queimadas e outras tantas, a começar pela Lei de Terras de 1850, que vedava o acesso a terras, num momento em que os negros estavam sendo libertados, e os pobres teriam chances de ser proprietários rurais. Na verdade, a opressão sobre o campo ainda é bem maior do que no meio urbano, pois a impunidade e, ainda, a falta de informação tornam-se complicadores natos.

As classes sociais no campo acompanham uma caracterização que pode ser assim definida, segundo Gomes Soto (2002, p.245):

- grandes proprietários e capitalistas agrários, que têm propriedade real dos meios de produção, divisão do trabalho que separa os trabalhadores diretos do responsável pelo empreendimento e orientação dos investimentos pela taxa de lucro;

- empresas familiares, com número variável de trabalhadores temporários, com atividade especializada, pequena mobilidade de capital, cálculo econômico para maximizar a renda líquida, o dono participa das tarefas, as relações não são formalizadas legalmente, a rentabilidade é frágil, não sendo suficiente para garantir a remuneração de acordo com a legislação;

- produtores camponeses, com posse de pequenas áreas, trabalho familiar, trabalho assalariado só temporário e mínima mobilidade de capital.

Essa divisão provoca um debate agrarista que clama por mudanças onde o agronegócio convive com a agricultura familiar, de forma desequilibrada, no tocante a direitos e políticas públicas, numa relação histórica já contada por Caio Prado Júnior (1979) e Alberto Passos Guimarães (1968) e, hoje, motivada pelo narrar daquilo que muitos autores determinaram em chamar de "questão agrária". ${ }^{1}$

Obviamente que o tema "questão agrária" traz discussões múltiplas de institutos multidisciplinares ligados à Sociologia, Economia, História e a ramos jurídicos diversos, que envolvem a propriedade, a violência, os direitos humanos, a tributação da terra e discussões que permeiam a desigual-

1 Ambos os autores, em suas obras, são clássicos em discutir o modelo agrário brasileiro firmado nas razões históricas conservadoras do poder dos senhores de terra, do peso jurídico da propriedade privada e da submissão dos legisladores em manter essa continuidade. 
dade social. Na questão agrária, está o cerne da ocupação do solo brasileiro, que concentra a maioria das terras em mãos de poucos, enquanto muitos desfrutam de uma pequena quantidade de terra, e outros, sem terra, não têm o que comer e onde trabalhar; daí, a necessidade da revisão da distribuição fundiária e o alívio da pobreza rural, por meio de políticas públicas que minimizem esse flagelo.

Os anseios sociais inserem-se na luta pela terra e pela reforma agrária, e esses institutos não se assemelham, mas podem se completar. A luta pela terra, conforme Martins (2000, p.19),

[...] atrai e polariza um conjunto bem maior de descontentamentos sociais, políticos e ideológicos, que poderão ser resolvidos por uma reforma agrária, cujo alcance é muito restrito em face de tantos e tão amplos questionamentos e das complexas necessidades históricas de que derivam.

Para Graziano da Silva (apud Soto, 2002, p.281), a reforma agrária deve ser parte de uma estratégia mais ampla de combate à pobreza no país. Ambos, Martins e Graziano, coincidem em dizer que o Estado é o agente central da reforma agrária. Portanto, mudanças estruturais na situação agrária do país dependem da sociedade civil, mas com a participação essencial dos representantes do Estado, que devem estar aptos a enxergar a área rural, a questão agrária, a fome e a miséria como partes de um mesmo todo, que ambiciona uma vida melhor para a sociedade.

Políticas públicas são necessárias para segmentar essa luta e modificar a situação indesejável ante os direitos humanos: "Por políticas públicas define-se o conjunto de regras, planos, estratégias, programas, projetos e omissões assumidos parcial ou totalmente por órgãos governamentais, visando a realização dos direitos humanos" (Zimmermann, 2007a, p.124).

Celina Souza (2003, p.27) assim se expressa sobre o tema: "Política pública é, por definição, estudar o governo em ação”. Zimmermann (2007a, p.125) considera que as políticas públicas apresentam critérios de transparência, responsabilidade e descentralização. No Brasil, essas políticas obedecem a uma postura de necessidade, mas não de direito, o que faz que as intervenções estatais de combate à fome e à pobreza se caracterizem, conforme Magalhães (2001, p.577), de forma precária, tímida e intermitente, não assegurando direitos sociais básicos à população pobre. Os benefícios 
das políticas públicas de proteção social ficam limitadas às elites, em vez de serem generalizados às camadas mais desfavorecidas da sociedade. As políticas sociais brasileiras, de modo geral, são voltadas para situações extremas, muito focalizadas, direcionadas aos mais pobres dentre os pobres, apelando muito mais à ação humanitária e/ou solidária da sociedade do que às políticas de Estado (Zimmermann, 2007a, p.127).

Assim, as políticas públicas que vão alterar a estrutura da sociedade devem radicalizar atitudes, ter participação social, alterar direitos, mobilizar recursos, analisar novas situações, pesquisar novos feitos para que alcancem os reais interessados. O Poder Executivo desempenha papel central na implementação de políticas públicas, e o Judiciário tem o papel de confrontar as políticas formuladas com os padrões jurídicos compatíveis, reenviando-as aos órgãos estatais pertinentes para que sofram as devidas modificações.

No âmbito da segurança alimentar, os Estados devem construir políticas públicas que modifiquem as relações com a terra, que dividam esta de forma mais equânime, que propiciem fomento às novas realidades, que alterem o tipo de produção, processamento, distribuição de alimentos, relações de trabalho e sustentabilidade ambiental. Os Estados devem construir políticas públicas que efetivamente protejam os direitos humanos e as liberdades fundamentais. ${ }^{2}$ Caso contrário, além da mobilização social, devem recorrer ao Judiciário para o cumprimento dessas políticas.

Doravante, serão apresentadas algumas situações em que o Estado, em conjunto com a sociedade civil, poderá intervir para alterar a insegurança alimentar no Brasil, por meio de novas opções de situações, já criadas pela realidade, de programas de alterações em modelos agrários, de fomento à agricultura familiar, de reforma agrária efetiva, de mecanismo ambiental favorável à proteção de grupos minoritários.

Por fim, as políticas públicas precisam incorporar os objetivos de mudança progressiva na distribuição de vida, especialmente no que concerne às relações políticas, sociais, tributárias trabalhistas, econômicas e ambientais. Só assim se pode manter acesa a esperança da segurança alimentar no Brasil. O Bolsa Família, então, seria apenas um paliativo precário e intermitente.

2 Como exemplo, pode-se afirmar que as políticas de seguro-desemprego, salário-família, aposentadorias e pensões são programas que se tornaram direitos consolidados. 


\section{O agronegócio}

O fato de os Estados incentivarem o desenvolvimento agrícola perpassa pelos incentivos e pela legislação que recai sobre ele. Sob o ponto de vista jurídico, já foi dito que leis somente não trazem atitudes, portanto a Constituição de 1988, proclamada democrática, trouxe o modelo jurídico da desapropriação e assumiu a função social. No entanto, na prática, reduziu a desapropriação e a produtividade, mantendo as grandes propriedades e o fomento ao agronegócio, em detrimento da propriedade familiar e do acesso à terra pelos despossuídos.

O agronegócio, segundo Gomes de Castro (2005, p.26), é o negócio agrícola definido como um conjunto de operações de produção, processamento, armazenamento, distribuição e comercialização de insumos e de produtos agropecuários e agroflorestais. Inclui serviços de apoio e objetiva suprir o consumidor final de produtos de origem agropecuária e florestal.

Mário Batalha (apud Castro, 2005, p.27) acresce que o agronegócio envolve o conjunto de atividades que se inicia na produção de insumos, até a chegada final ao consumidor, não estando associado a nenhuma matériaprima agropecuária ou produto final específico.

O agronegócio apresenta números grandiosos: a agricultura é responsável por $40 \%$ das exportações totais do País e 37\% dos empregos brasileiros. De cada $\mathrm{R}$ \$ 3,00 gerados no Brasil, $\mathrm{R}$ \$ 1,00 corresponde à atividade agropecuária. A carne bovina brasileira aumentou $85,2 \%$, e a produtividade, $85,5 \%$. O Brasil é o primeiro produtor e exportador de café, açúcar, álcool e sucos de frutas. Lidera o ranking de vendas externas de soja, carne bovina, carne de frango, tabaco, couro e calçados de couro. As projeções indicam que também será o principal polo mundial de algodão, biocombustíveis feitos de cana-de-açúcar e óleos vegetais, e, ainda, baterá recordes na produção de milho, arroz, frutas frescas, cacau e castanhas, além de suínos e pescados (Cafundó, 2005, p.48).

Diante dessa riqueza produtiva, há o contraste da fome e da miséria e de milhares de estabelecimentos que não conseguem produzir, e seus condutores são analfabetos, pobres e sem perspectivas de melhora. A própria estrutura do agronegócio reconhece que essa população merece o apoio de políticas públicas, sendo interessante a permanência dela no campo. De acordo com José Erasmo Soares (2005, p.110): 
É muito importante que a população rural possa permanecer em suas pequenas propriedades para reduzir o inchaço das cidades. É muito mais barato investir na adequação do modelo rural, do que no urbano. [...] Este modelo deve contemplar novas tecnologias e as prefeituras que deveriam investir em cooperativas, oferecer suporte técnico, cursos, ajudar na comercialização, produzir adubo orgânico, fortalecer a questão ambiental; só assim vencerá a pobreza que ainda atinge a maioria da população brasileira.

Percebe-se que os defensores da empresa agrária, voltada para a exportação, têm consciência da miséria brasileira no campo e atribuem somente ao poder público a responsabilidade de alterar esse quadro. Não assumem o papel de solidariedade, preocupam-se com os seus lucros e com a divulgação dos dados de aumento de produção, confiando que, assim, cumprem seu papel social de erradicação da pobreza.

A Sociedade Nacional da Agricultura (2005, p.44) define o agronegócio como a maneira de agregar valor aos produtos agrícolas, que deixam de ser entregues ao consumidor in natura e passam a ser comercializados já de forma beneficiada. Esse processamento implica profunda transformação que afeta a cadeia produtiva.

Essa entidade reúne grande número de associados voltados para o agrobusiness e, em suas metas, estabelece temas de reforma agrária, desenvolvimento sustentável, ecoturismo, fortalecimento do Direito Agrário e criação de uma justiça agrária, o que minimiza o quadro crítico do agronegócio capitalista. A consciência para essas discussões é um avanço imposto pelo mundo, em destaque pela União Europeia que exige, no momento da compra dos produtos agrários, a comprovação da função social e também mentalidade agrarista, uma vez que o professor Octavio Mello Alvarenga ${ }^{3}$ esteve à frente da Sociedade Nacional da Agricultura (SNA) por décadas a fio.

O agronegócio não é crime, nem sabotagem aos pobres. Simplesmente, é uma atividade exercida, quase sempre, de forma monocultural, preocupando-se muito pouco com o meio ambiente, envolvendo capital estrangeiro, clamando por altos empreendimentos, monopolizando mercados, trabalhando sob pressão internacional, estando voltado para a alta tecnologia

3 O professor Octavio Mello Alvarenga é fundador da Abda e um dos agraristas brasileiros reconhecidos internacionalmente, com várias obras publicadas. 
e exigindo apoio estatal diuturno. Muitas vezes, insere o trabalho escravo em seus negócios - como, há tempos, foi registrado, quem escraviza seus trabalhadores não são os proprietários mal informados, escondidos em fazendas atrasadas; ao contrário, são os empresários do agronegócio, produzindo com alta tecnologia, em fazendas de gado, café, soja e extrativismo de madeira (Sakamoto, 2006).

A condução do agronegócio é o fundamento da questão. O produtor inserido nessa seara passa pela concorrência internacional, porque seu produto é de exportação, ou concorre com o produto importado. Está adstrito ao comércio internacional, sofrendo todo o processo de concorrência e subsídios. "Há ânsia de ganhar cada vez mais, ou segundo os mesmos, há vontade de não tomar prejuízo." " Assim, efetivam suas práticas agrárias em ofensiva ao meio ambiente, estendem suas áreas, criam conflitos de terras, usam agrotóxicos indiscriminadamente, empregam trabalhadores em condições precárias ou desempregam a população local. E seus produtos não servem para alimentar sequer as populações de outros países, mas o gado dos estrangeiros. Entende-se o porquê de tanta produção e de tantas pessoas com fome e vivendo na miséria.

O agronegócio é patrocinado pelo governo, por meio de financiamentos, cuja natureza do dinheiro é pública. O Estado incentiva as práticas do agronegócio, que gera a insegurança do emprego e da renda, gera desigualdade no campo e danos ambientais irreversíveis. Então, por que essa prática é mantida nesse esquema de destruição?

O agronegócio é o motor da exportação, beneficia uma camada do poder, gera riquezas para um grupo de pessoas e cria o véu do progresso e do mito do crescimento. Pode ser diferente? Obviamente que sim e, felizmente, parece que os próprios empreendedores iniciam um procedimento de consciência que, ainda, é muito incipiente, mas que poderá ser conduzido para uma melhora significativa, inclusive, da segurança alimentar. A participação do Estado nesse processo começa pela fiscalização do trabalho e do meio ambiente e por medidas de repressão, como não emprestar dinheiro público para empresas que violam o meio ambiente ou mantêm trabalho escravo.

4 Trata-se de um comentário muito comum, encontrado em revistas de agronegócios e em entrevistas e conversas com grandes produtores. 
O agronegócio é danoso se conduzido em desrespeito às normas da função social. Pode ser executado se processado numa produção repensa$\mathrm{da}$, onde a economia deve rimar com a ecologia e a sustentabilidade social. Muitas empresas agrícolas têm se voltado para práticas de produção limpa, dentro de seus complexos agroindustriais; com isso, produzem de forma sustentável, ganham dinheiro, selos internacionais e, consequentemente, incentivos que, novamente, beneficiam-nas. É o caso das empresas agrícolas de café (Cornélio Procópio), açúcar (Sertãozinho) e madeira (Amazônia), que se integram em projetos sustentáveis e mantêm suas atividades agronegociais (Brandão, 2005, p.16-20). Ao contrário, há muitas e muitas empresas que ainda produzem, como em Santa Catarina, sem sustentabilidade alguma, contaminado águas e solos com dejetos de suínos, todos comercializados no ritmo do agronegócio e com vendas para o exterior (Pessotto, 2005, p.36). O Ministério Público tem atuado, porém ainda o trabalho está sob os termos de ajuste de conduta, para não haver prejuízo à comercialização dos produtos.

O agronegócio é vilão quando seu modelo é de destruição ambiental e humana. Com políticas públicas atuantes, pode-se convertê-lo em um outro papel, desde que não concentre terras, nem gere desigualdades. Esse modelo deve ter a intervenção imediata do Estado. A sociedade civil não pode tolerar a continuidade da proteção jurídica a essa situação perversa, que não permite o desenvolvimento humano. Onde há práticas de agronegócio destruidores, permanecem ou aumentam a pobreza, a mortalidade infantil e materna, a falta de acesso à educação, a desigualdade entre os sexos, as taxas elevadas de doenças infecciosas e a insustentabilidade ambiental. Essas situações são presentes no Mato Grosso, Amazonas, Amapá, em Roraima, Tocantins, no Pará e Maranhão (Amorim, 2007).

O modelo de política agrícola de economia familiar, ou empresa familiar, pode ser a grande solução para o problema da fome e da miséria no Brasil, por atingir a produção voltada para o mercado interno de abastecimento, por utilizar mão de obra com vínculo empregatício, ou não, por atingir uma população carente de oportunidades e de terra. Pode funcionar para o mercado interno, sob a constituição de diferentes moldes de uma empresa. Assim como há microempresas no setor urbano, pode haver, no meio rural, empresas agrárias, no mesmo estilo, que desenvolvam empreendimentos para a segurança alimentar, com condições de produtos saudáveis, de empregos 
humanos, sem exploração, originários de atividade agrária de produção sustentável, orgânica, para a população brasileira. Pode haver médias propriedades que cumpram função social e sejam bem-vindas ao campo. O que terminantemente não pode haver é a continuidade de uma política pública que concentre terras, beneficie o agronegócio, permita a exploração do homem e alimente a miséria e a desnutrição da população rural. Por isso, a grande via apresentada para a realização da segurança alimentar é vista num conjunto de políticas públicas que contemplem diversas mudanças e incentivos ao meio rural, atingindo novos atores sociais rurais, reforma agrária lato sensu, incentivo à propriedade familiar, respeito ao meio ambiente - todas elas práticas que alterem a base da política agrícola e fundiária, garantindo direitos, e não assistencialismo para a população pobre, em especial a rural.

É preciso educar o povo para demonstrar que a terra não é reserva de valor, não deve ser explorada, mas utilizada de forma sustentável. Deve ser ela meio de sobrevivência das gerações, merecendo tratamento diferenciado. A agricultura é o meio de alimentação universal de interesse público, portanto suas normas devem atender aos clamores sociais, e não ao interesse de grupos. O Direito Agrário deve zelar por esse procedimento.

\section{População agrária: novos e velhos atores sociais ante a segurança alimentar}

As raízes históricas do Brasil construíram um campo mais desigual do que toda desigualdade social existente no meio urbano. O sistema escravocrata, presente até o fim do século XIX, o sistema de grandes latifúndios, a monocultura, a economia de exportação, o dano ambiental rural, a ausência de direitos trabalhistas até $1973^{5}$ e a falta de política de redistribuição de terra, de reforma agrária e de acesso a terras devolutas, somados à incipiente política agrícola, constroem um quadro deplorável para os produtores e trabalhadores que, mesmo assim, resistem e desafiam o mundo com uma produção invejável. Mas, nessa construção, os pobres, os miseráveis,

5 Muito embora tenha sido editado o Estatuto do Trabalhador Rural em 1963, este nunca vigorou na prática. Somente em 1973 foi editada a Lei n 5.889 que, até hoje, tem parte de seus artigos em vigor, em razão do princípio da lei mais favorável. 
o analfabetismo, a desnutrição e o agravamento das doenças concentramse no meio rural. É importante ressaltar que, na opinião de Veiga (2005, p.70-1), o meio rural é muito maior do que o apresentado nas estatísticas. No Capítulo 1, foram apresentados os conceitos de imóvel rural, sob o ponto de vista jurídico. Quem delimita efetivamente os imóveis rurais são as prefeituras, pela lei de zoneamento. Estas, por sua vez, crescem de modo desenfreado; não existe país que conte mais cidades do que o Brasil: eram 5.507, quando do último censo demográfico, no ano de 2000. Mas são apenas 90 , por exemplo, com menos de 500 habitantes. A definição de cidade no Brasil é estritamente administrativa. ${ }^{6}$ Toda sede de município é cidade. ${ }^{7}$

Conforme Veiga (2005, p.77), é impróprio chamar de cidades as sedes dos mais de 4.500 municípios rurais, que no censo de 2000 apontaram menos de 20 mil habitantes. O caso extremo está, por exemplo, no Rio Grande do Sul, onde a sede do município União da Serra é uma "cidade" na qual o censo só encontrou 18 habitantes. Nada grave, fosse extravagante exceção. No entanto, entre as 5.507 sedes de municípios recenseadas em 2000, havia, por exemplo, 1.563 delas com menos de 2,5 mil habitantes. Essas cidades vivem em função do campo: os trabalhadores, em sua quase totalidade, estão envolvidos no trabalho agrário. Muitos deles passam o dia no meio rural e dormem nas periferias de sedes distritais, oficialmente contadas como urbanas, alimentando o disparate de que o Brasil concentra $81 \%$ de população urbana. Para Vilmar Faria (apud Veiga, 2005, p.78), seria rural a população dos 4.024 municípios, que tinham menos de 20 mil habitantes em 2000, o que, por si só, já derrubaria o grau de urbanização do Brasil para 70\%. Mas Veiga diz que esse critério seria complicado porque há muitos municípios com menos de 20 mil habitantes, muito próximos dos grandes centros urbanos e estes não poderiam ser rurais. Para que haja uma coerência, deveria se somar ao critério da localização do município o tamanho da população. Particularmente, este trabalho acrescentaria a preponderância da atividade

6 A concepção de cidade, conforme Veiga (2005), e da qual esta autora compartilha, é absurda. E mais absurda foi a criação de um Ministério das Cidades. Existem cidades que não passam de ficção. Esse raciocínio sobre a construção de cidades é da Era Vargas - Decreto-Lei n ${ }^{\circ} 311$ de 2 de março de 1938.

7 Em Portugal, para que uma cidade seja considerada como tal, precisa ter, ao menos, 8 mil eleitores e disponibilidade de oferecer um rol de serviços básicos além dos habituais, como corpo de bombeiros, hotéis, creches, ensino secundário e bibliotecas, entre outros. 
e da origem maior da renda da cidade. Com certeza, seriam muitos os municípios em que a população seria rural.

Percebe-se que o Brasil não gosta de ser rural e não quer sê-lo; ao menos, suas políticas públicas induzem a tal. Mas os que resistem a essa postura constroem sua bandeira de luta. A população, por sua vez, tende, cada vez mais, a ir em busca das cidades. Mas que vida existe nessas cidades? Os pobres estão indesejadamente nas periferias, no alto dos morros, cada vez mais distantes dos benefícios da vida urbana, sem direito de desfrutar de suas benesses. E por que não ficar no meio rural? Porque os modelos excludentes, insustentáveis, deixam a população rural mais pobre. Esses modelos têm, nas palavras de Maria Nazareth Wanderley (2000, p.30), três constatações fundamentais que endossam essa problemática.

A primeira delas é a de que a propriedade fundiária é a forma dominante de controle da terra no meio rural. Os espaços rurais foram historicamente muito marcados por uma dissociação entre a apropriação da terra e a função residencial. Os grandes e médios proprietários possuem a terra como investimento produtivo ou como mera especulação imobiliária. Eles não moram no meio rural, nem a sua família, o que cria um exemplo para as demais categorias sociais de que o urbano é melhor. Os trabalhadores, quando não expulsos de seu lugar de moradia, vivem mal, sem a infraestrutura necessária, sem conforto, o que faz o êxodo aumentar dia a dia.

A segunda constatação é a já argumentada por Veiga de que toda sede municipal, independentemente da dimensão, de sua população e dos equipamentos coletivos que dispõe, é considerada cidade. O meio rural corresponde ao entorno da cidade, espaço de habitat disperso, onde predominam as paisagens naturais e o uso das terras apropriadas para produção agrícola, ou como espaços improdutivos. As cidades passam a ser o prolongamento de suas vidas, é para lá que têm de ir estudar, consultar o médico, buscar o Poder Judiciário e, até mesmo, a religião. Há um mescla entre rural e urbano; grosso modo, fala-se no periurbano, um rural influenciado pelas cidades.

Quanto à população rural, ela é constituída pelas pessoas que se relacionam em função da referência ao patrimônio familiar, vinculadas, portanto, às unidades familiares agrícolas e aos laços de vizinhança, o que inclui os trabalhadores assalariados que permanecem no meio rural. Essa população computa os trabalhadores, chefes das unidades familiares, seus auxiliares, velhos, crianças, assalariados, temporários ou não. 
Hoje, o meio rural, no entanto, também se ocupa de uma população denominada por Wanderley (2000, p.32) de "migração de retorno". Volta-se para o meio rural aquele indivíduo com origens agrárias, ou não, que passa a ver o meio rural como uma nova opção de qualidade de vida. Isso ocorre naqueles locais bem servidos do conforto: transportes eficientes, meios de comunicação, clima agradável, patrimônio cultural de grande riqueza, belas paisagens. Moram no local e, para esse trabalho, são pessoas altamente interessantes, pois geram novos empregos, têm mentalidades ecológicas, em sua maioria, e, quando não moram no meio rural, passam os fins de semana ali, atraindo funções que podem ser urbanas ou rurais, em suas propriedades, utilizando-se de serviços de caseiros, limpadores de piscina, faxineiras, jardineiros. Esses proprietários, ou arrendatários, podem se utilizar de diferente expedientes de contribuição para a sustentabilidade alimentar. Criam novos habitats, novas oportunidades e, por vezes, criam possibilidades de turismo rural, que geram outras opções de segurança alimentar.

O impacto da proliferação das chácaras de fim de semana tem sido notável sobre a paisagem rural. Primeiro, porque contribuem para manter áreas de preservação/conservação do que restou da flora local e, muitas vezes, dão inicio a um processo de reflorestamento, mesclando espécies exóticas e nativas. Expulsam as grandes culturas que, em geral, utilizam-se de grandes quantidades de insumos químicos e de máquinas pesadas; dão novo uso às terras, com pequenas agriculturas, empregando novos cidadãos como caseiros, guardiões e jardineiros (Silva, 1977, p.84).

A volta ao campo foi estuda por Gisele Silva (2001, p.63), de forma a provar que o homem anseia pela "casa no campo", como uma manifestação em relação à natureza, onde não se quer mitificar a urbanidade como modo de vida mais evoluído e também não mitificar a ruralidade como o mais seguro e mais puro dos mundos. A proposta, portanto, é combinar as vantagens sociais, econômicas e culturais de uma borbulhante cidade com as qualidades ambientais e harmônicas do meio rural. Espera-se que haja água limpa e farta, que a terra gere alimentos sem agrotóxicos, que haja frutos para pegar com as mãos e comer na hora, com muito verde e aconchego.

A casa no campo para morar em definitivo, quando a aposentadoria vier ou quando se tenha juntado uma reserva financeira, é a primeira grande manifestação que este trabalho definiu como um direito humano a uma vida mais saudável, com segurança alimentar para as pessoas que optam 
por esse modo de vida e para todos aqueles que passarão a conviver com elas. A abertura desse nicho de mercado que retorna ao campo não significa que este seja um grupo de saudosistas bucólicos ou nostálgicos impertinentes. São pessoas que não querem violência, poluição, engarrafamentos, desrespeito como cidadãos. O sonho da vida com quantidade e qualidade. Isso não pode ser desprestigiado pelo Direito e pelo Estado, que deveria promover mecanismos de financiamentos rurais para se adquirir esse tipo de imóvel. Incentivos para esse mercado poderiam ser criados e valorizados. Democratizando-se o acesso à terra para esses atores sociais, novas frentes de trabalho, cooperativas, produção orgânica e biológica, além da defesa ambiental, ganhariam intensidade.

Cinco histórias de profissionais diversos (um médico, uma psicóloga, um engenheiro nuclear, um músico e uma professora de educação física) são narradas em reportagem de Sueli Gonçalves (2005, p.23), como situações de opção pelo meio rural, não como atividade de lazer, mas como troca definitiva de profissão. Todos eles passaram a exercer a atividade agrária, com sofisticação: ricotas defumadas, cabrito de corte, aguardente de banana, criação de trutas, tudo dentro de uma meta ecológica radical. Como se encerra a reportagem: "Todos eles têm os pés no chão e a cabeça nas estrelas".

Duran \& Perez (2000, p.25) veem essa nova situação sob o enfoque de produção, meio ambiente e lazer:

Esta é a nova relação homem natureza que apresenta um caráter dual: por um lado, uma dimensão agrária, imbricada diretamente com os problemas ambientais dos sistemas intensivos de produção e, por outro, uma dimensão rural estreitamente conectada com os efeitos sobre o meio ambiente, usando estes cada vez mais como espaços de ócio e diversão por parte da cidadania que busca um maior tempo livre.

O lazer no campo tem representado também uma nova fonte de investimento, geração de emprego e renda em nível empresarial e familiar. Os locais rurais que passaram a desempenhar a função turística ganharam em números e qualidade, gerando melhorias não só para o rural, como também para o urbano, beneficiando as cidades que ganharam visibilidade, impostos e melhorias de fomento estatal e, até mesmo, federal, socialização entre os povos, troca de experiências, que podem colaborar na paz, direito humano de terceira geração. 
Já está confirmado, na Europa, que o turismo, hoje, representa 7\% do PIB e que sua importância resulta num fenômeno econômico e de necessidade social. Pierre Py (2002, p.2) agracia seu leitor esclarecendo que hoje o turismo, de modo geral, é uma expressão de liberdades, supõe a maior liberdade pública que é o direito de ir e vir, relacionada às liberdades de comércio, distribuição de renda, associação, produção, consumo, a qual, para bem caminhar, carece do apoio do Direito.

No Brasil, o turismo não possui um ramo jurídico específico para administrá-lo. O turismo rural, como já afirmado, não se constitui no Brasil como uma atividade agrária e, portanto, não está, ainda, sob os auspícios do Direito Agrário. Mas, desde os idos de 2000, toma-se essa defesa, e, em diversos artigos assinados por esta autora, defende-se que a expansão desse ramo pode ser desastrosa no aspecto ambiental se não for ritmada por normas agrárias que a disciplinem.

Ballestero Hernandez (1990, p.239-40) contempla o turismo rural como uma atividade agrária, por se realizar no meio agrário, por valorizar os produtos agrários, por difundir a cultura e o artesanato rurais. Mesmo respeitando as diferenças encontradas na Europa, sobre turismo rural e agroturismo, ${ }^{8}$ ambos estão a pleno vapor e são altamente respeitados pela União Europeia que disponibiliza, por meio deles, mecanismos para manter a população rural em seu meio, criar prosperidade para as populações do campo e, ainda, propiciar lazer a preços relativamente módicos.

Na maioria dos países, no meio rural, o turismo constitui-se de uma atividade exótica. No Brasil, ensaia seus passos de uma forma animadora, não oferecendo riscos e incertezas de ordem temporal, como as demais atividades agrárias. Aparece no cenário rural como uma segunda grande oportunidade de oferecer segurança alimentar, gerando novos empregos, novas rendas com as vendas dos produtos artesanais, criando aquilo que Almeida et al. (2000, p.8) intitularam de "grandes benefícios para o produtor rural": aumento e diversificação da renda, ocupação da mão de obra familiar relativamente ociosa, interação social e cultural com um público de alto nível social e educacional, e aproveitamento racional de espaços ociosos.

8 Turismo rural envolve turismo verde, ecoturismo, turismo de aventura, agroturismo, turismo cultural. Para maiores detalhes, ver Maniglia (1999). 
Os custos para a implantação do turismo rural são relativamente modestos: envolvem adequação das instalações e pessoas para atender os turistas. Isso, na sua forma mais simples, podendo chegar, em sua forma mais sofisticada, à instalação de uma empresa agrária voltada para a rede hoteleira. O turismo rural, em todas as suas modalidades, é visto pelo Conselho Nacional de Meio Ambiente (Conama) como uma forma de integrar comunidades, beneficiando-se regiões com atividades sociais e econômicas. Meirelles Filho (apud Almeida et al., 2008, p.24) considera que o turismo rural tornou-se uma grande alternativa para as propriedades rurais no Brasil. A agricultura e a pecuária já não são tão rentáveis, e fazendeiros, em má situação financeira, descobrem que podem obter bons lucros abrindo suas propriedades para o turismo. As experiências brasileiras realizadas são inúmeras e todas com sucesso.

As fazendas do Vale do Café, no interior do Rio de Janeiro, somam 210 propriedades rurais, com teor histórico e cultural, que preservam a memória do País. São muitos hotéis que, em parceria com as cidades, oferecem múltiplas opções, como o caso da cidade de Conservatória, que promove saraus nas fazendas (Caldas, 2007).

Atualmente, existem no País 5 mil fazendas envolvidas com o turismo rural; a pioneira delas, na cidade de Lages, em Santa Catarina, viu seu pequeno produtor crescer e aumentar sua renda. São 16 estados que já abriram suas porteiras para hospedar ou, simplesmente, receber visitantes da cidade. Cerca de 70 mil pessoas estão envolvidas nesse setor, incluindo patrões e empregados. As pequenas propriedades abarcam 43\% das atividades de turismo rural, e apenas 19\% das fazendas apresentam mais de 300 hectares e 7\% delas têm mais de 1,5 hectare (Kiss, 2007).

O comércio dessa atividade envolve animais, hortifrutigranjeiros, agricultura, peixes, doces e queijos. As prefeituras e organizações da sociedade civil têm se envolvido com projetos de incentivo, assim como os governos estaduais. Os programas mais avançados estão nas regiões Sul, Sudeste e Centro-Oeste. Há grandes grupos de estrangeiros interessados em conhecer o meio rural brasileiro; os interesses residem não apenas nos passeios, mas também no conhecimento de novas técnicas e no intercâmbio de conhecimento que podem melhorar a vida dos proprietários rurais (Cesaro, 2006). Mesmo assim, não existem linhas específicas de crédito. O Programa Nacional de Agricultura Familiar (Pronaf) admite a possibilidade de 
usar seu crédito para o agroturismo, e o Serviço Nacional de Aprendizado Rural (Senar) ministra cursos para capacitar essa atividade.

Lamenta-se que, nas regiões mais pobres (Norte e Nordeste), o processo turístico seja tímido e conte com muito pouco apoio. Na Amazônia, há turismo na selva, e no Nordeste, sítios que promovem vaquejadas. Zimmermann (2000, p.139) aponta que no Nordeste há um bom potencial para o turismo rural, nas fazendas históricas de Pernambuco e Bahia. Na Bahia e no Ceará, o governo do estado apoia, em parceria com o Serviço Nacional de Apoio às Empresas (Sebrae), o turismo, porém de forma pouco clara. Na região Norte, existe bom potencial, mas o autor diz não conhecer incentivos. Como meio de fazer crescer e aprimorar essa atividade, sugere-se que políticas públicas sejam tomadas, como linhas de crédito, promoção e marketing, pesquisas, estudos e projetos estaduais, em parceria com os ministérios federais envolvidos.

Outros velhos atores sociais, mas a quem é dada uma nova expressão, que merecem ser considerados como um segmento a sustentar a segurança alimentar com seus próprios recursos são os povos das florestas, perante os quais o Direito Ambiental se curva, pelo potencial que eles representam em colaborar no desenvolvimento sustentável ou em manter os recursos naturais. Esses povos podem e conseguem viver numa meta de sustentabilidade se receberem orientação para o manejo dos recursos de que dispõem. Ora, o extrativismo é uma atividade agrária significativa não só em termos ambientais, mas também é uma riqueza ambicionada por todos aqueles que já destruíram seus bens naturais. Entretanto, os povos das florestas, ribeirinhos, indígenas, quilombolas e pequenos agricultores que vivem do extrativismo foram inseridos no grupo de insegurança alimentar, apesar de muitos fazerem parte de projetos com grandes empresas ou de comercializarem seus produtos em rede internacional. As razões para tal não são outras senão a relação de desigualdade que se insere no comércio, o que lhes garante poucos rendimentos, poucas chances de se estabelecer em processos de troca, já que vivem distantes e também em regiões onde o plantio é difícil e proibido para eles.

A Amazônia é o berço das riquezas exuberantes; seu povo domina todo o conhecimento de suas plantas, que podem ser utilizadas como alimentos, remédios, perfumes, cremes, madeiras, inseticidas biodegradáveis, especiarias. Com todo o seu conhecimento, o povo amazonense das florestas e 
das beiras de rios comercializa muito pouco dos seus produtos ou vende a sua produção para grandes empresas, que absorvem todo o lucro, pagando quantias pífias para os extratores. Dentro de um plano de turismo, esses comerciantes conseguem vender raízes, perfumes, cremes, frutas, mas com muito pouca estrutura e, ainda, mesclados com uma alta dosagem de folclore e mandinga que, muitas vezes, não consegue convencer o turista da seriedade do produto. Sementes e cordas estão em alta para a produção de bijuterias, e, então, as grandes empresas colocam suas etiquetas nesses produtos e os vendem para o exterior ou em aeroportos e lojas de grife a preços altíssimos, ficando com todo o lucro dos nativos. O mesmo acontece com os pescadores e com os povos que retiram resina da seringueira. ${ }^{9}$

Os povos das florestas de outras localidades passam pela mesma situação de miserabilidade, enquanto extraem riquezas. Esses povos são fundamentais para a manutenção dos recursos naturais. Eles detêm a técnica sustentável e conseguem manter esses recursos renováveis. O problema que enfrentam, além do baixo custo da matéria-prima que vendem, são as pressões pelo uso de suas terras.

Entrementes ser o extrativismo sua fonte principal de renda, o povo da Amazônia vive às margens dos rios, igarapés, paranás e furos, alimentamse do peixe, do açaí e da mandioca, e a terra, como terra, não tem valor econômico, importante é o que dela se extrai. Daí registrar-se a importância da mandioca como fonte de segurança alimentar desse povo que poderia ser aproveitada de melhor forma. Gursen de Miranda (2005, p.301-3) ressalta que a mandioca é uma das mais importantes fontes de carboidratos para os consumidores de renda mais baixa, em países tropicais da América Latina; é um produto natural sem agroquímicos, do qual deriva uma série de alimentos, em especial a farinha, que seria uma importante alternativa de combate à fome para milhões de pessoas. Como ressalta o autor, as pesquisas sobre essa fonte de energia são desprezadas, e o governo pouco se interessa por seu estudo e aproveitamento. Não existe no Brasil uma política direcionada aos interesses regionais; da mesma forma, os organismos internacionais interessam-se muito mais pela biodiversidade e pela água

9 Esse relato provém de diversas conversas com os nativos, em viagens desta autora a Belém, no mercado Ver-o-Peso, onde se comercializa de tudo; a Boa Vista, em Roraima, com os indígenas especialistas no artesanato de corda e sementes; a Manaus e vilas anexas, onde o artesanato e a borracha imperam. 
potável, abstraindo-se das pessoas lá nascidas e criadas, com sua necessidade de alimentação.

Embora reconhecido constitucionalmente o direito desses povos em usar as terras, na prática, esse direito tem sido usurpado pelo branco, causando transtornos de ordem de segurança alimentar, educacional, cultural, de saúde e de integridade física.

As terras dos índios são consideradas bens da União e os índios têm usufruto permanente sobre elas. As terras das comunidades remanescentes dos quilombos são reconhecidas na Constituição como de propriedade definitiva dos quilombolas. Também são consideradas terras tradicionalmente ocupadas aquelas áreas de uso comum, voltadas para o extrativismo, a pesca, a pequena agricultura e o pastoreio, focalizadas por diferentes instrumentos jurídicos que buscam reconhecer suas especificidades, dentro da Constituição Federal, ou das constituições dos Estados ou, ainda, nas leis dos municípios onde se situam (Almeida, 2005-2006, p.26). Esse significado de terras tradicionalmente ocupadas tem um preceito jurídico marcante, reconhecido na Convenção 169 da OIT: além do direito de usar essas terras para sua manutenção, têm esses povos o direito à preservação ambiental e cultural, todavia são impedidos de tanto, pela ganância e exploração das grandes empresas.

Muitas dessas terras estão sendo utilizadas para plantação de florestas homogêneas (pinus e eucalipto), projetos agropecuários, mineração, hidroelétricas com barragens e bases militares (idem, p.30). Essa situação deflagra a expulsão dos povos, que é o apogeu da miserabilidade dessa gente que perde, inclusive, sua identidade. Quando permanecem em seus territórios, são obrigados a trabalhar para a grande empresa, como mão de obra barata, ou a vender seus produtos a preços ínfimos.

Em 2001, um grupo de mandingueiras, em entrevista à revista Globo Rural, cobrava apoio do governo federal para as suas atividades de venda de perfumes e remédios (Bezerra, 2001). Naquele momento, apenas três produtos eram inclusos na pauta oficial de exportação, mas, com certeza, muito outros eram vendidos de forma clandestina. São múltiplas as situações vividas, cada uma com sua peculiaridade, o que delongaria por demais o tema. Apenas a título de conhecimento, poderiam ser citados, no Paraná, os faxinais (exploração coletiva da terra para produção animal e conservação ambiental); Leis do Babaçu Livre, no Maranhão, Pará e Tocantins; na Bahia, Lei do Licuri Livre. 
Em 2004, outra reportagem tratava do mesmo assunto, ou seja, da luta dos povos da Amazônia para sair de suas misérias. Esta, mais promissora, já registrava a presença de outros tantos produtos que viraram marcas no exterior, como o cupuaçu, a andiroba e a copaíba, porém revelava as dificuldades de se instalar o manejo sustentável para sair do extrativismo danoso. A Empresa Brasileira de Pesquisa Agropecuária (Embrapa), universidades amazonenses, o Museu Goeldi e outras instituições reivindicam regras claras, medidas efetivas e criação de centros de pesquisas para que os brasileiros possam investir e melhorar a vida dos povos das florestas. Enquanto esses povos passam por desnutrição e miséria, os estrangeiros levam as plantas que se transformam em remédios, no exterior, e, a posteriori, voltam para as prateleiras das farmácias brasileiras (Bezerra, 2004d).

Para ressaltar esses povos, cuja inseguridade alimentar persiste, fica delimitado que as razões para sua fome e miséria podem ser contornadas a partir das soluções advindas dos movimentos sociais, de associação, cooperativismo e de uma dura e rígida cobrança dos órgãos governamentais, que pouco têm se preocupado em modificar a situação atual e em permitir que esses povos vivam com dignidade. O trabalho de Chico Mendes, que foi precursor em manter esses povos em suas atividades, serviu de exemplo de organização e demonstração do poderio para os povos que, aos poucos, estão se conscientizando de sua capacidade de viver com dignidade, se apoiados na união e na solidariedade. O exemplo das mulheres de Pereru, no estado do Pará, configura a força da associação das mulheres da comunidade que, dentro de um projeto de inserção social, venceram dificuldades e estão conquistando dias melhores. Unidas, elas trabalham nos manguezais, chamados por elas de "mangal", catando e beneficiando caranguejos, que são vendidos para os restaurantes de Belém. Denominado Associação de Mulheres Paraenses de Pereru (Ampap), esse grupo desenvolve o processamento da carne de caranguejo, dentro de técnicas sustentáveis, com higiene e preservação do manguezal. Da catação à elaboração da massa, todo o trabalho é feito de forma cotizada, em área juridicamente considerada de área de preservação permanente. Essas mulheres enfrentam problemas da concorrência, que procede à catação sem critérios e vende o produto a preços irrisórios para atravessadores e marreteiros. Sofrem ainda com o problema do transporte, já que não dispõem de veículos próprios. As mulheres têm de viajar transportando o material no colo, 
gastam com passagens e refeição na capital, sobrando-lhes muito pouco. Apesar desses problemas, as mulheres se sentem valorizadas e têm a comemorar a sua independência financeira, a sua valorização como pessoas e a melhoria de vida de suas famílias. A comunidade, graças ao trabalho dessas mulheres, ganhou telefone público, posto policial, lanchonete e, como elas mesmas se expressam, o melhor foi o reconhecimento e a cidadania (Bezerra, 2004c).

A sociedade civil organiza-se também na Bahia, numa associação fundada por jovens agricultores, envolvidos na produção de sisal e cujo objetivo é organizar trabalhadores, eliminar os atravessadores na comercialização, valorizar a cultura e modificar a vida de milhares de sertanejos. O sisal, como salientado em capítulos pretéritos, é uma atividade danosa que absorve trabalho infantil e condições degradantes. Por meio dessa associação, os envolvidos estão recuperando sua dignidade, com técnicas mais modernas e melhores ganhos. É qualidade de vida obtida pela educação, o que se efetiva na escola da associação, cujo currículo, além das disciplinas formais, inclui Agricultura, Engenharia Rural e Zootecnia, com especial atenção para o armazenamento de alimentos e o uso racional da água (Bezerra, 2006).

Em Goiás, o baru, fruto típico do cerrado, é o responsável pelo sustento de numerosas famílias, por meio do fairtrade, comércio de origem europeia, que significa comércio justo e que permite que pequenos agricultores reunidos numa associação tenham acesso direto ao mercado, comercializando seus produtos sem intermediários. Esse fruto que, antes, somente servia de alimento às vacas é, hoje, transformado em farinha, castanha torrada e granola e vendido pelo processo de economia solidária, rendendo nova vida para os assentados goianos, os quais, além de extrativistas, são hoje também plantadores (Kiss, 2006).

Percebe-se a organização da sociedade civil realizando com afinco projetos que, muitas vezes, não são apoiados pelo governo. Para tanto, tornam-se imprescindíveis a união de esforços e a dedicação de pessoas com visão para plantar a semente da melhoria.

Quanto aos quilombolas, o último censo mostrou que os negros estão em situação de segurança alimentar bem inferior à do branco. Enfrentam os desafios para viver e ter as terras de sua comunidade e, ainda, pelo próprio isolamento, padecem de insegurança alimentar. Alguns grupos que já conseguiram a propriedade definitiva de suas terras, em São Paulo, no Vale do 
Ribeira, iniciaram um processo de modernização e passaram a investir em produção orgânica, plantio de juçara e artesanato. Com apoio da Universidade Estadual de Campinas (Unicamp) e da Escola Superior de Agricultura "Luiz de Queiroz" (Esalq - USP), desenvolvem projetos sustentáveis na região. A comunidade organizou-se e vende bananas comuns climatizadas e orgânicas, inclusive para o mercado exterior. Das fibras da banana, fazem artesanato, investem em cursos de resgate de cultura, principalmente entre os jovens, e a característica máxima do grupo é a solidariedade. A associação formada pelos quilombolas construiu, inclusive, uma moderna pousada para abrigar os visitantes e, assim, aumentar sua fonte de rendas. A mais difícil etapa em todo esse processo é a regularização fundiária (Bezerra, 2004a).

Tudo poderia caminhar nesse ritmo para os povos de comunidades tradicionais, porém a fiscalização é deficiente, a legislação é falha, há descaso oficial, corrupção e ingenuidade da população.

Com os indígenas, a situação assemelha-se no descaso, a partir da demarcação de suas terras. Estes têm de disputar com fazendeiros a posse das terras que sempre lhes pertenceram e enfrentar o abandono do Estado que os tutela. A segurança alimentar desses povos depende da condição dada a eles para viver. Se ficam em suas terras, vivendo dentro de seu processo de cultura e costumes, a sustentabilidade está garantida. Todavia, se retirados de seu habitat, vivendo ao descaso nas cidades ou em disputas com o branco, são humilhados, vivem sem cultura, sem comida e, fundamentalmente, sem saúde. A Fundação Nacional do Índio (Funai) e o Conselho Indígena Missionário (Cimi) não estão conseguindo realizar seu trabalho de forma satisfatória, porque lhes falta o apoio estatal. A disputa com os fazendeiros de arroz, pela terra da Raposa do Sol, em Roraima, terra dos indígenas, legalmente demarcada, é um exemplo que muito do que consta como direito está somente no papel.

Nesses casos, em especial nos dos povos de comunidades tradicionais, a luta pela terra, pela posse do espaço que lhe dá alimento e cidadania é condição sine qua non para sua segurança alimentar, além de ser essencial para a sustentabilidade ambiental. O Poder Judiciário tem papel relevante na condução das ações, em que os fazendeiros, considerados grileiros, invadem as áreas, expulsando os nativos, e, quando estes resistem, há violência e mortes. De forma acintosa, firmados numa posse clandestina, os 
fazendeiros consideram-se donos e disputam, na Justiça, a posse de áreas constitucionalmente reconhecidas como dos povos tradicionais. Infelizmente, muitas reintegrações são concedidas contra legem, para beneficiar os que detêm poder financeiro e até político. Mais uma vez, presencia-se que a desigualdade é fruto das minorias que demandam por ilegalidades concedidas pelo Estado, o qual camufla uma situação, sempre em nome do crescimento, endossada por parte da sociedade que se cala e busca não ver o que não lhe interessa diretamente.

Encerram-se essas elucubrações, concluindo-se que alternativas outras existem para se buscar uma melhor sustentabilidade para os atores do meio rural, que podem gerar melhorias, como o retorno ao campo, passando pelo turismo rural, pelo envolvimento da sociedade civil, da organização dos povos tradicionais. Em todo esse contexto, é fundamental que o Estado esteja presente para, ao menos, oferecer garantias mínimas, por meio de políticas públicas, que não somente as de distribuição de rendas. Empréstimos, incentivos, linhas de crédito especiais, infraestrutura de transporte, saúde, divulgação e cumprimento do que já foi considerado direito é o mínimo que se espera de um Estado social.

Marca o Direito Agrário sua posição fundamental na busca da efetivação da paz social, garantindo a todos o direito à vida, ao alimento, ao ambiente saudável, com respeito ao homem, efetivando-se a justiça em toda a sua dimensão, com fiel cumprimento ao disposto na função social da propriedade rural.

Fábio Konder Comparato (1997) equipara a função social da propriedade ao direito à vida, lembrando que há muitas formas de sucumbir a vida, de forma violenta, mas também pela fome, pela miséria e pela doença. Quando uma propriedade não cumpre sua função social, ela nega a todos esses direitos de vida, alimento e saúde.

O princípio da solidariedade, no Brasil, ainda não se efetivou de forma ortodoxa, por meio de uma cidadania capaz de buscar uma melhoria conjunta e equiparar, ao menos, procedimentos mínimos de garantia de sobrevivência. Encontra-se solidariedade fraterna advinda da religião e colaboração de proteção, não no tocante ao interesse público. A força dos movimentos sociais, o trabalho voluntário, as ONG têm buscado formar opiniões e a contribuição para a melhoria de vida coletiva, fazendo o que o Estado deveria estar encarregado de, ao menos, exigir de forma legal. 


\section{A reforma agrária, o princípio democrático e a segurança alimentar}

O tema "reforma agrária" já ocupou muito espaço nas plataformas políticas, jurídicas e nos fóruns sociais, mas, até o presente momento, no Brasil ainda torna-se motivo de discussão pelo seu discurso que insiste na sua realização, como também chama a atenção pela sua não efetivação. $\mathrm{O}$ tema que, em tempos pretéritos, foi pauta constante nas discussões socialistas e motivo para as esquerdas realizarem seus pressupostos de igualdade ainda traz em seu bojo um pouco do ranço e do preconceito relativamente ao assunto, predileto das classes dominadas, em confronto com as elites dominantes.

Tal procedimento tem raízes históricas nos movimentos de origem popular no Brasil, que, ao longo dos anos, sempre clamaram pela divisão da propriedade rural para a efetivação da justiça social. Não se pode afastar o instituto da reforma agrária da realização da minimização das desigualdades, mas, no momento reinante, é necessário pensar numa reforma agrária que se adapte às realidades dos tempos, em que a ideia de produtividade e função social esteja presente para, assim, cumprir o intento da melhoria da segurança alimentar.

O Direito Agrário foi, por muitas vezes, confundido com a reforma agrária, e, hoje, não se pode permitir que esse equívoco permaneça no ordenamento. O Direito Agrário estuda, por certo, os mecanismos jurídicos de propiciar e efetivar a reforma agrária, mas não se limita a este estudo, trazendo em seu conteúdo uma amplitude de institutos que estudam a posse, a propriedade, a desapropriação e outras formas de acesso à terra, tendo como cerne a atividade agrária, conforme já foi amplamente demonstrado.

A reforma agrária vincula-se ao princípio democrático, na concepção do Estado Democrático de Direito, aclamado nas constituições que protegem os direitos humanos e que se relacionam à ordem econômica e social. Raupp Rios (1998, p.203) chama a atenção para o fato de que "a caracterização do Estado Social como opção jurídica fundamental expressa na Constituição de 1988, por sua vez, conecta-se diretamente com a concepção de democracia adotada, na qual os postulados de justiça social têm lugar essencial". Assim, não se pode conceber que a terra esteja em mãos de poucos, concentrando uma estrutura agrária injusta. Necessário se faz pensar que a políti- 
ca de reforma agrária integrada na Constituição deve ser procedida, pois o legislador pátrio assim entendeu ao elaborar a Carta Magna, colocando esse tema em posição antes não exigida, mas que, agora, como tema constitucional, há de ser cumprido. Não há mais que se discutir se a reforma agrária deve ser feita ou não.

O entendimento jurídico define claramente que a propriedade que não cumpre função social é passível de reforma agrária, seguindo os trâmites legais e os regramentos que tratam desse assunto. Todavia, conforme já tratado no capítulo referente ao Direito Agrário, é corriqueiro verificar na jurisprudência que a função social está reduzida à produtividade da propriedade. É o Judiciário cedendo aos caprichos do agronegócio, que se farta em descrever as supersafras como pressuposto definitivo de imunidade à reforma agrária.

Transcorridos quase vinte anos da promulgação da Constituição Federal, questiona-se, ainda, se a reforma agrária é necessária e se há terras disponibilizadas para tal fim, e também se, no atual momento histórico, vale ainda realizar esse instituto. Seria simples responder a esse questionamento: a reforma agrária seria desnecessária se se tivesse superado a desigualdade social nesse ínterim, fato que já fora largamente refutado. Também não seria viável falar em reforma agrária se o meio rural tivesse alcançado metas de desenvolvimento e se a segurança alimentar estivesse em níveis de tolerância para todos os setores da população.

Se o Direito Agrário é responsável pela realização do instituto da reforma agrária, é nele que se vai encontrar o fundamento para o Estado, por meio de uma política, fazer valer a efetivação desse procedimento. Primeiramente, deve-se tomar em conta que reforma implica uma mudança, uma alteração de estrutura, dando-lhe nova concepção. A partir desse raciocínio, vale lembrar o disposto por Miguel Neto (1997, p.217): "A mudança do estado agrário atual tem que operar-se sobre algumas condições ideais que lhe garantam validade, permanência e segurança". O autor citado propõe que seja posto fim ao modelo feudalista agrário e da grande concentração de terras em mãos de poucos, de forma a beneficiar os trabalhadores do campo, reduzir a pobreza e promover o crescimento social. Entende-se, pois, que a reforma agrária é necessária, a partir da redistribuição de terras já constante do Estatuto da Terra $\left(\operatorname{art} .1^{\circ}, \S 1^{\circ}\right)$, mas, sobretudo, a partir da revisão do processo produtivo, uma vez que a posse ou a propriedade 
da terra, por si sós, nada acrescentam à solução do problema social que se enfrenta nessa seara.

Dessa forma, os propósitos da reforma agrária são: melhor distribuição de terras, mediante modificação no regime de sua posse e uso; atendimento aos princípios da justiça social; promoção do aumento da produtividade - o que se torna coerente com as metas propostas na Constituição de 1988, que contempla o Estado Social Democrático de Direito.

Contudo, ao se falar de reforma agrária, não se pode reduzir esse instituto ao simples fato da desapropriação de terras improdutivas, conforme disposto na legislação. Aliás, o próprio termo "improdutivo" traz consequências funestas para sua realização. Se se partir do ponto, conforme leciona José Gomes da Silva (1996, p.96), de que produtivo quer dizer aquilo que produz, que é fértil, mostrando claramente uma conotação de capacidade de produzir, de fertilidade intrínseca, não se pode olvidar, todavia, que, obstante a terra com essa qualidade possa ter um potencial produtivo, pode ela não estar sendo utilizada para tal fim, não se encontrando sob uso econômico, ou em utilização, como estabelece o IBGE, ou em exploração, como queria o Incra. Nesse raciocínio, continua o autor: "A expressão propriedade produtiva esconde ainda uma armadilha legal e uma tática latifundista”.

Na prática, a vigorar o princípio de que não se desapropriam as terras produtivas, restarão somente para essa finalidade as propriedades improdutivas, cujas terras estão ociosas ou não têm capacidade de produzir. Se não se interpretar adequadamente, restarão para a reforma agrária somente charcos, carrascais, areiões, piçarras e pirambeiras. Portanto, ainda no contexto legal, é preciso rever e interpretar adequadamente os termos. Afora isso, colocar terras improdutivas nas mãos de assentados que possuem força de trabalho e vontade de melhorar sua condição de vida não é suficiente. A terra é apenas o substrato para a produtividade, que só será atingida com tecnologia, gerenciamento e inserção nos sistemas agroindustriais.

A questão fundiária não se exaure nos conceitos tradicionais da reforma agrária, pensada nas décadas de 1950 ou 1960, em que a fixação do homem na terra era o suficiente para seu progresso e fim da desigualdade. Miguel Neto (1997, p.219) assim se expressa:

[...] considerar a concentração de terras como aspecto determinante da desigualdade é racionalizar a partir de um único ângulo da questão. O problema dos 
excluídos não está na desigualdade de patrimônio, mas na ausência de renda. Não se vive de patrimônio, mas sim de renda.

Mais adiante, afirma: "Nesse passo, a reforma fundiária questiona toda estrutura econômica e deve se adaptar à nova e mutante realidade mundial em que cada vez mais a ineficiência se torna letal".

Concorda-se, em parte, com o autor; é certo que simplesmente promover assentamentos com terras desapropriadas não é o suficiente; centrar a questão na retomada do trabalhador agrário com um casebre e um par de vacas num curral não é o objetivo proposto. Como estabelece Claus Germer (1994, p.149), "salvar o cidadão, que vive em cima da terra, é colocar esse produtor rural num contexto econômico em que ele vá sobreviver dignamente, com sua família. Então é esse o trabalho político que têm que ser feito".

As pesquisas, todavia, demonstram a produtividade dos assentamentos, ou os seus fracassos, o perfil do assentado e até mesmo os seus bens. Mas não se ocuparam, até então, em demonstrar se os assentados melhoraram suas condições, depois que passaram a receber uma parcela de terra, em comparação à vida que levavam antes. Há sinais seguros de que grande parte não deixa a terra - apesar da sua condição precária - porque ainda assim se encontram em melhor condição de vida do que grande número de brasileiros oficialmente considerados miseráveis, uma vez que, ao menos no item sobrevivência, conseguem alimentação. Esse fato deve ser considerado no aspecto social, pois, mesmo que dentro de uma perspectiva errônea, a garantia básica de sobrevida está garantida com o acesso à terra. A pretensão sobre a reforma agrária é muito mais que o alimento. Pensa-se na cidadania plena, na ascensão social dos assentados, e, para tanto, é preciso uma política que os integre às demandas nos novos meios de produção rural. $\mathrm{O}$ abandono dos assentamentos e o favelamento rural são sinais de que a reforma agrária não é distribuição de terras.

Caminha-se pensando que a reforma agrária é um processo social e econômico, com apoio jurídico para sua efetivação. As lutas sociais devem contemplar a luta pela terra e pela política agrícola, principalmente como mecanismo de assegurar o trabalho. Este é o sentido da reforma agrária atual, como preleciona Romeiro (1994, p.131): "Este é o sentido da reforma agrária no Brasil: ampliar as oportunidades de emprego no campo, de modo a reduzir a pressão da oferta da mão de obra no mercado de trabalho 
urbano industrial". Mais do que isso, é preciso pensar que a reforma agrária propicia a produção de alimentos para um grupo de excluídos, que vivem à margem dos direitos humanos. Ziegler (2007), relator especial da Comissão de Direitos Humanos para o Direito à Alimentação, entende que

[...] o acesso à terra é fundamental para a redução da fome; em muitas partes do mundo, as pessoas lutam para sobreviver porque estão sem terra ou porque suas propriedades são tão pequenas que não conseguem sobreviver decentemente. A reforma agrária tem que ser justa, leal e transparente [...] e deveria ser dada mais atenção aos modelos alternativos propostos pela sociedade civil, em particular o conceito de soberania alimentar. Especialmente o acesso à terra $e$ a reforma agrária devem ser elementos fundamentais do direito a alimentação.

Esse reconhecimento internacional sobre a necessidade de reforma agrária está manifesto no Banco Internacional para Reconstrução e Desenvolvimento (Bird) que seguiu a orientação de seus economistas de desenvolvimento, os quais constataram que a desigualdade severa na posse da terra retarda o crescimento econômico, o lenimento da pobreza e os esforços para o uso sustentável do solo. Com base nesses ensinamentos, acredita-se que o fenômeno dos sem-terra somente será solucionado com as mudanças estruturais realizáveis na política, e não nos mercados, o mesmo acontecendo com as políticas agrícolas, que são tão hostis à agricultura familiar e tão benéficas ao agronegócio. A reforma agrária de mercado não altera a estrutura a fundiária, portanto não reduz desigualdades.

Quando se questiona sobre a necessidade da reforma agrária, um dos fortes motivos para sua não realização centra-se no fato de que a produção alimentar não está concentrada nas mãos dos pequenos, mas nos grandes produtores, que anteriormente recebiam a denominação de latifundiários e que, após a Constituição de 1988, autodenominam-se produtores rurais produtivos, a fim de se verem livres da desapropriação. Esses produtores, nos gráficos econômicos, demonstram que conseguir índices de supersafras perpassa por maquinários, grandes extensões de terra, pulverizações aéreas, sementes importadas e outras técnicas. Em entrevista, o presidente da Sociedade Rural Brasileira, João de Almeida Sampaio Filho, afirmou que, se não houver todo esse aparato, não compensará o plantio desse grão (cf. Moreira, 2004). Assim, entende-se que a reforma agrária pode ser dispen- 
sada em um primeiro momento. As terras devem repousar nas mãos dos grandes, para que estes promovam a alimentação dos demais. Todavia, a realidade revela a grande falácia da grande propriedade e da alimentação do Brasil.

Para a opinião pública, é passado que, em face da modernização do campo, a reforma agrária representaria um retrocesso no desenvolvimento da agricultura. Entende-se que é necessário se desmistificar esse preconceito que associa a questão da democratização da terra e o modelo de produção em larga escala dos agronegócios. Ao se pretender uma reforma agrária, objetiva-se dar continuidade a um crescimento rural calcado na produção familiar, que poderá, inclusive, desenvolver outras formas de atividades, que não as essencialmente agrícolas. Obviamente, já ficou esclarecido que a reforma agrária produz um assentamento com trabalhadores, sem condições de progredir, se as políticas públicas não estiverem voltadas para esse fim. Maluf (2007, p.134) é categórico:

A produção agroalimentar oriunda dos assentamentos de reforma agrária, por sua vez, pode cumprir papel relevante numa estratégia de SAN (Segurança alimentar e nutricional), desde que disponham de assistência técnica e apoio creditício e comercial. As experiências do Brasil (pela negação) e de muitos países (pela afirmação) permitem sustentar que a reforma agrária, se ampla e acompanhada de instrumentos adequados, é essencial para redefinir a estratégia de desenvolvimento de um país, ao mesmo tempo em que o enfoque de SAN contribui para atualizar o significado da reforma agrária.

Mas também é preciso lembrar que os grandes produtores necessitam e usam e, ainda, abusam do crédito rural para seus negócios. Nas devidas proporções, ambos dependem do apoio estatal, contando com a política agrícola para sua manutenção.

A Constituição de 1988, tratando da questão, reafirma o que já vinha apregoado no Estatuto da Terra, isto é, que a política agrícola deverá ser cumprida para atender ao desenvolvimento econômico no meio agrário. Posteriormente, a Lei de Política Agrícola de 1991 veio reforçar o estímulo à pequena produção, mas parece que ainda não foi suficiente para convencer que os pequenos proprietários não formam o bucólico campesinato, muito menos a economia de subsistência; os produtores familiares podem 
formar complexos agroindustriais de suma importância para a economia local, agrupando trabalhadores, qualidade de vida, lazer e progresso para regiões que vivem da agricultura. As barreiras de que o proprietário familiar tem parcos recursos e não conseguirá se impor no mercado rural advêm de um preconceito que remonta à fase colonial, em que só os grandes senhores de terra sobreviviam porque o Estado só a eles socorria.

$\mathrm{O}$ avanço tecnológico permite a entrada de proprietários familiares e não mais somente daqueles trabalhadores que se dedicam full time às atividades rurais. Pode haver trabalhadores com atividades paralelas, dedicando-se ao meio rural e ao urbano, ou, ainda, chefes de família trabalhando a terra, enquanto seus outros familiares trabalham em atividades na cidade. É importante que o modelo vindo da reforma agrária permita o desenvolvimento da comunidade agrária e, paralelamente, esvazie as cidades; para tanto, é preciso estimular a vida no campo ou, ainda, incentivar o plantio de hortas nas cidades. Alguns modelos dessas vidas podem apresentar resultados alimentares surpreendentes. As hortas feitas nas zonas periféricas das cidades plantadas por essas pessoas que se alternam entre o rural e o urbano motivam a melhoria das áreas inativas nos subúrbios. O aproveitamento de terrenos baldios faz parte do projeto de agricultura urbana e começou pelas mãos de Temp, um alemão que aprendeu, em seu país, que todo canto livre vira um canteiro e que a exclusão social pode ser vencida com a participação da sociedade civil (cf. Kiss, 2003). Ele fomentou a ideia de melhoria de alimentação entre os pobres das periferias que se alargou por diferentes localidades da cidade de São Paulo. É o campo ensinando a cidade, instalando a criação de verduras e legumes, e também algumas frutas nas cercanias das cidades, naquilo que se denomina zona periurbana; é o "alargamento da zona rural" nas beiras de estradas, nas margens dos rios, em regiões públicas e terrenos residenciais.

Não deixa de ser uma reforma agrária firmada na reforma de mentalidade, de ideias fundamentadas, na interação entre urbano e rural. Esse projeto deve contar com o apoio das prefeituras que muito pouco colaboram com programas de desenvolvimento das áreas rurais. Graziano (2002, p.64) incentiva essa interação, fundado na ideia de que

[...] as regiões metropolitanas ainda dispõem de áreas de uso agrícola e de preservação ambiental, bem como pelo efeito polarizador, que as metrópoles exer- 
cem em seu entorno seria importante resgatar a experiência de gestão dessas regiões. Especialmente, porque a gestão ambiental impõe uma planificação integrada do uso do solo e dos recursos naturais que não pode admitir nenhum corte de caráter meramente geográfico-administrativo, como é hoje a linha que separa o urbano do rural, ou um município do outro.

A interação entre campo e cidade deve ser somada a projetos sociais, políticas públicas, organização da sociedade, organização de cooperativas e sustentabilidade ecológica, para, assim, fomentar-se uma reforma agrária de sucesso, movida para a segurança alimentar.

Nesse aspecto, há de se considerar que a mera distribuição de alimentos não se constitui na melhor forma de concretizar o direito à alimentação. Há de se promover trabalho, renda e dignidade que a reforma agrária pode propiciar. Para Oliveira \& Racine (2004, p.140), os programas de distribuição de alimentos para tanto têm que existir de forma compensatória, porém não podem ser os principais de um país. As mudanças têm de ser estruturais; as pessoas têm de adquirir seus próprios alimentos. A reforma agrária é o mecanismo ideal para tal fim que, além do alimento produzido, pode também ser mecanismo para uma alimentação equilibrada, que respeita os hábitos alimentares e a cultura de cada região, aproveitando os frutos, inclusive da natureza, de forma sustentável.

A reforma agrária pode vencer a pobreza, a desnutrição e a fome. O médico nutricionista Carlos Monteiro (2004, p.187-8) comenta que essas três situações envolvem a alimentação. A pobreza corresponde a uma insatisfação das necessidades humanas elementares, como a comida, o vestuário, a educação e a saúde, decorrentes de uma falta de renda. A desnutrição ou a deficiência nutricional é o padecimento provocado por uma alimentação insuficiente em energia e nutrientes ou por um inadequado aproveitamento biológico dos alimentos, geralmente por causa de enfermidades de tipo infeccioso. E a fome, mais difícil de definir, divide-se em aguda e crônica. A primeira é um grande apetite e a segunda, a mais grave, é a que não propicia ao indivíduo a energia suficiente para manter seu organismo e suas atividades cotidianas funcionando corretamente. Completa o autor que, como são definições distintas, merecem mais que uma solução, porém, a seu ver, a pobreza é a que mais deve ser combatida. Aumentar a renda das pessoas propicia avanços importantes, e o acesso à terra é um mecanismo para se 
empregar e fazer produzir. Finaliza, dizendo que a distribuição direta de alimentos deve ser o último dos recursos, quando se apresentam situações graves, como a seca do Nordeste. Sobre a distribuição de cestas básicas, pondera que esta não funciona, pois levam-se produtos alheios às culturas regionais e, ainda, muitas vezes, com produtos sem o teor necessário para alimentar com qualidade.

As políticas públicas sustentadas nos direitos humanos fazem real o sentido de que a reforma agrária é um direito fundamental, fundado no Estado Democrático de Direito. É o instrumento jurídico, definido pelo Estatuto da Terra, destinado à propulsão da justa distribuição de terras e da produtividade. Liberato (2006, p.83-4) expõe que

a reforma agrária está intimamente correlacionada com a dignidade da pessoa humana, uma vez que os indivíduos só adquirem condição digna ao possuírem uma situação de sobrevivência; neste sentido, a reforma agrária possibilita a propulsão da dignidade da pessoa humana. Este instituto jurídico pode ser considerado um direito fundamental do homem, uma vez que é capaz de materializar e efetivar os direitos subjetivos inerentes à condição humana.

Nessa lógica, o direito à alimentação está relacionado a outros direitos, como o direito à terra, à água, ao saneamento, à saúde, ao trabalho, à moradia e a outros de caráter civil e político, todos num raciocínio de indivisibilidade, como pressuposto de qualquer política pública. O Brasil tem se esforçado na luta contra a fome, mas a reforma agrária para esse fim ainda é tímida. O verdadeiro sentido da terra ainda precisa ser mais bem assimilado.

No aspecto jurídico, a função social, em seu sentido amplo, é o pressuposto para esse fim. Mares (2003, p.130-1) explica que existe uma falácia cruel e desumana que esquece voluntariamente os objetivos fundamentais estabelecidos na Constituição, tentando convencer o povo de que a propriedade privada é o único, o mais importante, sagrado e divino direito e que todos os outros são apenas sonhos, esperanças, quimeras e desejos inalcançáveis. Quando essa técnica não funciona, entram em cena a astúcia dos políticos, a inteligência dos intérpretes, a brutalidade da polícia, dos exércitos privados, reprimindo o grito dos que teimosamente surgem no horizonte. No Brasil, é rotina presenciar essa realidade contra os que anseiam por uma justa distribuição de terras. 
Para se entender por que, justamente no campo, os índices de fome e miséria são mais acentuados, basta verificar a ausência de reforma agrária e a expansão da produção agrícola para exportação controlada por agricultores mais ricos, detentores das melhores terras, deslocando os pobres para as áreas marginais de consumo ou deixando-os sem terra. Junto com a expulsão dos pobres, vão-se também os recursos ecológicos que se deterioram tanto em função dos pobres, que tentam seu sustento às margens de rios e florestas tropicais, como em função dos ricos, que os afundam em insumos, adubos, pesticidas e fertilizantes químicos.

A reforma agrária mundialmente comprova que a distribuição de terras para famílias rurais pobres e sem terra pode ser uma maneira efetiva de melhorar o bem-estar rural, conforme Ziegler et al. (apud Rosset, 2006, p.320). Os autores constataram uma relação forte entre reforma agrária e a redução da pobreza. ${ }^{10}$ Rosset (2006, p.328) relata, baseado nas pesquisas do trio citado e também nas observações de Stédile, que os beneficiários da reforma agrária têm renda anual equivalente a 3,7 salários mínimos, enquanto os que não têm terra auferem uma média de apenas 0,7 do mínimo. A mortalidade infantil entre famílias beneficiadas por reforma agrária caiu para a metade da média nacional, o que representa um poderoso argumento a favor da ideia de que, para se criar uma economia rural camponesa, a reforma agrária não é apenas boa para o desenvolvimento econômico local, mas também constitui uma política social mais efetiva do que permitir ao mercado continuar expulsando os pobres de áreas rurais para cidades superpopulosas.

A reforma agrária, para ser sucesso, depende para sua realização da sociedade como um todo, mas ao Estado cabe torná-la um direito fundamental a ser construído, em terras de boa qualidade, com serviços básicos, infraestrutura, apoio técnico, respeito ambiental, respeito cultural. Assim, será bem-sucedida, distinguindo-se das fracassadas que levaram dinheiro público em vão.

Reforma agrária não é assistência social ou política caritativa para indigentes; é direito fundamental e um dos pilares de sustentação da soberania alimentar, que beneficia toda a sociedade e não só os pobres do campo. Mas existe um outro segmento que considera a reforma agrária obsoleta. São os

10 Os autores citados apresentam uma série de dados, inclusive internacionais, que comprovam a melhoria da vida rural onde se fez reforma agrária. 
que dizem não e se escoram em argumentos de que a reforma agrária não traz sustentabilidade para as famílias. É, por exemplo, a opinião de Sampaio Filho, presidente da Sociedade Rural Brasileira, que afirma que "o modelo atual de reforma agrária transfere a miséria das cidades para o campo" (apud Moreira, 2004, p.10).

Não seria natural, nem ao menos aceitável, dizer que a reforma agrária é uma decisão corretamente aceita pela sociedade. No Brasil, no dizer de José de Sousa Martins (1999, p.70), a propriedade fundiária é uma das bases essenciais do sistema econômico e, sobretudo, do sistema político. Portanto, é a partir daí que se cria o primeiro impasse para a construção da cidadania rural. A história da colonização demonstra que os pobres do campo serviam muito para serem escravos, para oferecerem mão de obra barata, e a eles foi negado o acesso à terra, e terras foram distribuídas aos estrangeiros, mas negadas aos nacionais. Essa construção do passado reflete, até hoje, na mente de muitos que, mesmo na condição de sem-terras, apoiam os grandes proprietários contra a luta dos pequenos ou dos movimentos sociais, simplesmente por ideologias baratas que lhe foram ensinadas numa educação viciada, baseada em valores da burguesia. Trata-se de parte dos empecilhos à luta pela terra ou à fertilidade da agricultura familiar. Esse segmento nem ao menos enxerga que o prejuízo da ausência de reforma agrária reflete-se na alimentação, nos preços dos produtos, na conturbação das cidades e que eles próprios são vítimas de sua negatória.

O não à reforma agrária também emerge das próprias leis que, em sua maioria, são feitas para não serem cumpridas, uma vez que são elaboradas exatamente pelos inimigos daqueles que exigem as reformas sociais.

José de Sousa Martins (1999, p.71) descreve esses fatos:

As grandes reformas sociais no Brasil, como a abolição da escravatura, foram propostas pelos representantes do pensamento radical, os liberais, mas postas em prática pelos conservadores, ou como a proclamação da República, propostas pelos radicais da época e consumada contra eles pelos militares, na verdade herdeiros da tendência centralizadora, profundamente presente nas contradições do Estado brasileiro, e oriundas do absolutismo monárquico, em cuja crise esse Estado foi gerado. Esse jogo político envolvendo tendências opostas responde pelo modo contido como as reformas sociais e políticas são concretizadas no Brasil. 
Como exemplos reais disso, há a aprovação do Estatuto da Terra pelos militares, que muito pouco, ou quase nada, fez pela reforma agrária; o Plano Nacional de Reforma Agrária de 1985; o Banco de Terras, feito para não alterar a concentração de terras, além de outras tantas formas utilizadas para intimidar a reforma agrária.

O não à reforma agrária também vem, em especial, de cientistas políticos que supõem que as pessoas que clamam por esse modelo falam em camponês, economia de subsistência, ou tentam propor reformas de cunho socialista, à moda marxista. Parece que um dos sociólogos que passaram a adotar essa opinião foi o gaúcho Zander Navarro que, no Congresso de Direito Agrário, em Brasília, em 2002, perante um grande público, manifestou-se dizendo que o Brasil não necessita mais de reforma agrária, aberta alguma exceção a certas regiões do Nordeste. ${ }^{11}$ Questionado sobre o assunto, posicionou-se afirmando que o processo da terra é irreversível na situação capitalista de grandes monoculturas. Pensa o sociólogo que o Brasil necessita achar outra solução, criar empregos no campo, mas não sonhar com reforma agrária. Essa opinião foi reiterada em entrevista concedida ao jornal O Estado de S. Paulo (Arruda, 2007), em que fica claro que, para ele, reforma agrária só no polígono das secas; no Centro-Oeste, haveria necessidade de uma política de mão firme, com a agricultura patronal produtora de grãos exigindo contrapartidas no setor trabalhista e ambiental; no CentroSul, apoio à agricultura familiar; na Amazônia, uma moratória na expansão da soja e a formação de assentamentos no Pará; além de se fazer necessário o fim do Incra, uma instituição deplorável, em sua opinião. Para ele, o tempo de reforma agrária acabou.

Há de se considerar que outros também se manifestam contrários à reforma agrária e à agricultura familiar, considerando-as como retrocesso do campo e não percebendo as boas chances de trabalho que essas pessoas podem conseguir. Claus Germer (1994, p.149), em ensaio recente, afirmou ser inútil a agricultura familiar para o emprego agrícola. Os argumentos repousam sobre o fato de que a agricultura familiar, para concorrer com

11 No Congresso de Direito Agrário, patrocinado pela Abda, indignada, a plateia que o ouvia protestou, lamentando que é triste o fim dos que trabalham na terra, no desatino dos que esperam trabalho sem chances, já que, como já exaustivamente demonstrado, a monocultura não gera empregos, mas utiliza a mecanização em grande escala. Todavia, essa é uma opinião de um sociólogo que comunga com a opinião da oligarquia rural. 
a patronal, tem de se atualizar de tal forma que, por certo, não gerará emprego. Só que os agricultores familiares trabalhando estarão, sem dúvida, ocupando-se e incentivando seus filhos ao trabalho, ao contrário do que ocorreria se estivessem vendendo suas terras para os monocultores ou migrando para cidade para concorrer com os desempregados urbanos.

Apesar dos opositores, fica inalterado o compromisso adotado nesta pesquisa, a favor da reforma agrária e da agricultura familiar.

\section{A agricultura familiar e a segurança alimentar}

Produto da história do campesinato, a agricultura familiar, conforme Marie Claude Maurel (1997, p.104), "é a expressão de uma articulação sempre particular da família e da exploração ou do empreendimento agrícola, segundo as definições usuais nas sociedades industrializadas, como é o caso da sociedade francesa contemporânea".

Para a autora, o estudo deve repousar sobre a seguinte égide:

Tradicionalmente, a noção de agricultura familiar (ou de agricultura enquanto atividade familiar) repousa sobre a ideia de uma identidade entre família e exploração. A unidade de produção é uma família, ou seja, entre outras coisas, um grupo de trabalho, no qual os membros estão unidos por laços de parentesco, um grupo que se constitui e se renova sobre a base de relações familiares. No esquema da atividade familiar, a exploração fornece um retorno permitindo assegurar a subsistência do grupo e representa um patrimônio cuja transmissão aparece como um objetivo essencial das estratégias de reprodução familiar.

Alterado o conceito tradicional de família e sob julgamento o clássico posicionamento sobre a agricultura, pode-se verificar que a agricultura familiar tem sua importância dentro do contexto em que atua, tomando em conta as metas a serem atingidas por ela e as proposituras, depositadas pelo Estado, em seu reconhecimento. No caso da França, citada na definição, observa-se que o Estado lhe atribui uma importância sobranceira, sem, todavia, radicalizar o termo familiar. Permite-se que a propriedade rural seja explorada somente pelo seu chefe (homem ou mulher), juntamente com seu 
cônjuge, ou mesmo sem ele, como forma de assegurar o domínio da terra e de vincular seu proprietário ao espaço rural, para que aí se fixe a família, até mesmo por razões hereditárias, podendo ser explorada por algum de seus membros.

A preocupação com o êxodo rural e consequente desemprego nas cidades faz que o agricultor francês seja retido em sua função, com estímulos governamentais, e, por isso, sempre que se fala em agricultura familiar, remonta-se a esse modelo tido não mais como camponês, não mais como cenário bucólico, mas como mecanismo atuante de refrear parte dos problemas urbanos e agir dentro duma visão de lucro, formando complexos agroindustriais e turísticos, que se revelam como empreendimentos familiares, cujo modelo de funcionamento é a realização de uma produção para o mercado, onde o trabalho permanece essencialmente familiar, contanto com a ajuda eventual de terceiros, mas em atividades que diversificam e que visam a metas modernas e eficazes.

A caracterização da unidade familiar clama por um sistema classificatório, construído a partir de adjetivações dicotomizadas, cujo termo contraposto é a unidade capitalista de produção agrícola ou empresa capitalista, que, assim definida por Delma Neves (1995, p.21), forma, como bem relata essa autora, um locus da utopia de resistência ao sistema capitalista, quando está integrada nos propósitos de unidade familiar, que estabelece como meta a busca da autonomia, a minimização da dependência ao mercado, a defesa do autoconsumo e, em certos casos, a resistência à pauperização ou à proletarização. Todavia, hoje se fala na unidade familiar de produção, cuja definição sociológica é diferente da unidade familiar simplesmente. Essa é uma unidade híbrida que se origina, conforme Neves (1995, p.30), do modelo camponês hoje já fracassado, mas que se estrutura com frente para o mercado, produzindo de maneira a satisfazer as necessidades da família, que pode ser usada, ou não, como mão de obra total na terra, mas que garante a ela sua sobrevivência e lhe assegura um lucro suficiente, inclusive para garantir pessoas da família que nela não trabalham.

Maria Nazareth Wanderley (1995, p.2-3) considera que

[...] a importância e o significado da agricultura familiar depende, antes de mais nada, da associação de sua presença na sociedade com valores considerados socialmente positivos: tradição, desenvolvimento, eficiência econômica, proteção 
da natureza são possíveis caracteres que, atribuídos a certos grupos de agricultores, lhes conferem legitimidade social. A sociedade reconhece a contribuição econômica, social e política ou cultural de seus agricultores e os apoiam nas transformações que lhe são impostas pelo desenvolvimento.

Dessa forma, quando se propõe um estudo sociojurídico sobre a agricultura familiar, obriga-se a verificar o passado de cada país e o tipo de estímulo que se dá à efetivação desse modelo que, com leis regularizadoras e metas de investimento, em médio prazo, pode, sem dúvida, construir uma sociedade mais justa, com menos desigualdade.

O principal problema para se efetivar a agricultura familiar é o acesso à terra. Quem recebe terras de programas de reforma agrária são os cadastrados no Incra e os derivados do MST. Poucos estão na terra, oriundos de projetos de colonização do governo - a maioria desses projetos fracassou. Outros tantos são pequenos produtores que, a duras penas, vêm mantendo suas terras herdadas ou arrendadas. Alguns compraram lotes por meio do Banco da Terra e são identificados como pequenos produtores. Esses grupos de agricultores formam perfis variados de personalidades, com um núcleo homogêneo de interesses, que se volta para um investimento produtivo que garanta uma produção não mais para a subsistência somente, mas objetivando a inclusão no mercado do agronegócio, com chances e perspectivas de se estruturarem como empresas agrárias. Não se pode mais pensar em agricultura familiar como núcleo de subsistência, embora, ainda em muitos locais, tenha esse significado, ou, ainda pior, nem ao menos o agricultor se mantém com dignidade nesse local.

No Brasil, é sabido que o fator regional influi sobremaneira no desenvolvimento da agricultura familiar. Os estudos feitos ao longo de regiões diversas confirmam que o centro-oeste de Santa Catarina e o Rio Grande do Sul são os responsáveis pelo maior número de agricultores familiares de sucesso. Algumas regiões de São Paulo trazem marcas de produtividade e desempenho, e muito pouco de bom resultado é registrado no Nordeste. O Centro-Oeste, por suas características de grandes extensões de terra, concentra-se em outro tipo de atividade que não a familiar, e o Norte, já na exploração de castanha e no reflorestamento sustentável, vem apontando bons resultados nas produções familiares coletivas. Mas, no Brasil, a agricultura familiar é um espaço em construção. 
Sob o ponto de vista legal, a recente Lei da Agricultura Familiar (Lei ${ }^{\circ}$ 11.326/06) reconhece a agricultura familiar como segmento produtivo e representa um novo marco para as políticas públicas destinadas ao desenvolvimento rural e, consequentemente, à melhoria da segurança alimentar. A lei define os conceitos da agricultura familiar e do agricultor familiar e prevê a descentralização - com a participação de municípios, Estados, governo federal e produtores rurais - no desenvolvimento e na gestão dos programas agrários.

A agricultura familiar é responsável, atualmente, por 10\% do Produto Interno Bruto (PIB) brasileiro e representa $40 \%$ do PIB na agropecuária. A agricultura familiar no Brasil reúne hoje 4,2\% de estabelecimentos rurais familiares, representa $84 \%$ dos estabelecimentos rurais e emprega $70 \%$ da mão de obra do campo, conforme Manuel dos Santos, presidente da Confederação dos Trabalhadores da Agricultura (Contag). Além disso, é responsável pela maioria dos alimentos na mesa dos brasileiros. Segundo o ministro do Desenvolvimento Agrário, à época da promulgação da lei, Guilherme Cassel, "a agricultura familiar passa a existir do ponto de vista legal e fica reconhecida através de políticas públicas permanentes, seja de crédito, de assistência técnica, de comercialização, de seguro agrícola e de igualdade para as mulheres” (Ministério do Desenvolvimento Agrário, 2007).

Paradoxalmente, o Brasil sempre registrou um desprezo em relação à agricultura familiar, por seu retorno ser para o mercado interno e por satisfazer a população local, mesmo sendo a maioria das propriedades rurais brasileiras. Hugues Lamarche (1997, p.16) afirma que a agricultura familiar é, ao mesmo tempo, uma memória, uma situação, uma ambição e um desafio. Do valor atribuído a cada um desses elementos, dependerão suas características, suas exigências e seu futuro. Portanto, o apoio à agricultura familiar depende das políticas públicas e da disputa entre a grande propriedade, que realiza a produção de exportação, e o pequeno, que produz para o consumo interno. As palavras de Neves (1997, p.33) revelam essa situação:

As políticas públicas são analisadas como um dos instrumentos de ação do Estado e de expressão de disputas em torno de recursos e de regras definidoras e consolidadoras de interesses específicos. As disputas, portanto, são compreendidas como constitutivas das ações sociais, políticas em especial em que grupos de interesses se constituem no confronto travado em campos sociais determina- 
dos, bem como em instâncias do aparato estatal, onde as conquistas podem ser legitimadas, institucionalizadas e legalizadas.

A implementação do Programa Nacional de Agricultura Familiar (Pronaf) fez que a agricultura familiar passasse a fazer parte do discurso político referente não somente às questões agrárias e agrícolas, mas também aos debates sobre comércio internacional e modelos de desenvolvimento. Temas como segurança alimentar, multifuncionalidade e agroecologia, por exemplo, têm na agricultura familiar uma categoria referencial (Romano \& Delgado, 2002, p.287).

Assim, a agricultura familiar sempre foi mostrada pelos grandes grupos como um obstáculo ao desenvolvimento rural, por sua inutilidade econômica, por sua baixa produção, ausência de tecnologia e pelo atraso do campo. De certa forma, isso foi permitido pelo Estado que pouco investiu e não se preocupou em dar um patamar de importância real a esse segmento que alimenta o País. Os dados do Ministério do Desenvolvimento Agrário (2007), em parceria com a FAO, confirmam que a agricultura familiar é responsável pela maioria dos alimentos na mesa dos trabalhadores brasileiros: $84 \%$ da mandioca, $67 \%$ do feijão, $58 \%$ dos suínos, $54 \%$ do leite, $49 \%$ do milho, $40 \%$ das aves e ovos, entre outros.

Ocupa-se em afirmar que a agricultura familiar é um desafio em melhorar as condições de vida da população, favorecer alimentação saudável em quantidade e qualidade, e construir cidadania ampla e participativa, ao gerar trabalho e vida no campo, sem inchar a cidade com fome e miséria.

O Estatuto da Terra, ao classificar as propriedades, delimitava, sabiamente, o latifúndio, o minifúndio, a empresa rural e a propriedade familiar. Esta última representava o tamanho ideal de uma propriedade para ser explorada pelo agricultor e por sua família, absorvendo toda sua força de trabalho, garantindo-lhe a subsistência e o progresso social e econômico, com sua área máxima fixada para cada região e tipo de exploração e, eventualmente, trabalhada com a ajuda de terceiros.

Fernando Sodero (1968, p.213) entendia ser esta a propriedade ideal, para ser concedida como lote para a reforma agrária. O fundamento de sua posição repousava no fato de que a propriedade familiar representa o sistema de agricultura empresarial familiar e associativa (cooperativas integrais de reforma agrária), integrada num desenvolvimento planificado. Dessa 
forma, o Poder Público não apenas promove e cria condições de acesso do trabalhador rural "à propriedade da terra economicamente útil”, como gera condições de progresso social e bem-estar coletivo. Fixava-se, assim, uma relação adequada entre o homem, como produtor, e a terra, como bem de produção.

Nesse diapasão, constituiu-se a propriedade familiar como a fração ideal para a exploração do pequeno proprietário: são pequenas propriedades que utilizam mão de obra da própria família, têm renda originada no seu empreendimento, e o agricultor familiar é o gestor de seu trabalho.

Os movimentos sociais elogiaram a lei, mas esperam que o contido em seu teor seja cumprido, assim como o posto na Lei de Segurança Alimentar, pois ambas representam entrelaçamentos fortes de produção e garantia de alimentos, especialmente porque a agricultura familiar emprega o trabalhador rural, produz alimentos para a mesa do brasileiro, e a sua própria produção pode ser destinada aos programas de aquisição de alimentos do governo. Isso é o que vem acontecendo em diferentes locais do Brasil, com apoio dos governos locais e federal. A título de exemplo, relata-se que em Muqui, no Espírito Santo, a prefeitura compra alimentos orgânicos cultivados por produtores que aplicam a metodologia da produção agroecológica e os utiliza na merenda escolar. Segundo os dados da direção da escola, com essa alimentação saudável, até o rendimento escolar melhorou. Em Macapá, os produtores familiares vendem cestas para os funcionários públicos, por meio de um convênio com o governo do Estado e a Embrapa, e também já foi comprovada a melhoria de vida do produtor que, para tal feito, deve se organizar em associações ou cooperativas (Sebrae, 2006b,p.88).

Os índios do Mato Grosso, em Campinópolis, enfrentaram, durante o ano de 2004, um alto índice de mortalidade, pela falta de alimentos. Num convênio firmado entre o Banco do Brasil e o Sebrae, em parceria com o ator Marcos Palmeira, que cultiva orgânicos há dez anos, foi instalado um projeto de apoio a esses índios, para desenvolvimento da agricultura orgânica para consumo próprio e para o mercado, e os resultados foram surpreendentes na melhoria da alimentação das famílias do local (Sebrae, 2006a, p.90).

O entrave para uma melhor eficácia dessa política era a Lei de Licitações, que restringe a autonomia dos órgãos públicos em realizar compras diretas do produtor familiar, sem a necessária formalidade da documentação, que favorecia as grandes empresas fornecedoras de alimentos. Hoje, 
a Lei $\mathrm{n}^{\circ}$ 10.696/03 instituiu um mecanismo legal que permite a compra direta e a compra antecipada de produtos da agricultura familiar, o que foi e é uma grande inovação para a política de segurança alimentar e nutricional, e fortalece dois objetivos principais: o acesso à alimentação e a produção/ distribuição local de alimentos. Isso significa melhoria das condições nutricionais da população, geração de emprego e renda junto aos agricultores familiares (Martins \& Moreira, 2004, p.128).

A pequena, ou no melhor entendimento, até a média propriedade pode se constituir em unidades de produção familiar. Por regra, os proprietários dessas terras exploram seu imóvel por conta própria ou com a ajuda de sua família. São pessoas que herdaram suas terras ou as adquiriram pelo processo de legitimação, ou, ainda, são posseiros, que ambicionam a aquisição do título, mas cuidam da terra com desvelo de proprietário. Instrumentalizam sua atividade com sua força de trabalho e inserem-se nos objetivos de produção semelhantes aos dos assentados, inclusive fazendo-se valer de capacitação técnica e crédito rural especiais. Seus interesses estão, sem sombra de dúvida, muito mais próximos dos empregados rurais do que dos grandes proprietários. Estes trabalham a terra, mas de forma indireta, determinando ordens, na condição de empregador. Os pequenos proprietários, chamados também de camponeses, usam mão de obra paga em dinheiro (em espécie, somente em situações excepcionais, exercendo, apenas em raras ocasiões, um controle sobre o trabalho alheio).

Luiz Inácio Germany Gaiger (1987, p.69) entende que esse personagem, o camponês,

não é um trabalhador assalariado, despossuído totalmente de seus meios de produção. Contudo, não é mais que, nominalmente, o mestre da sua produção, não o impedindo a propriedade imediata dos meios de produção de encontrarse em uma situação análoga a dos proletários. [...] Os camponeses, em condições de capitalização, têm a oportunidade de converterem-se em empresários capitalistas, explorando o trabalho assalariado agrícola, condição da reprodução capitalista do capital.

Poucos são os que atingiram esse patamar, até então.

No Brasil, as condições têm sido muito mais favoráveis para que o camponês se proletarize. Os pequenos proprietários, ao longo dos últimos anos, 
têm sido expulsos de suas terras, pelas condições que enfrentam de péssima política agrícola; uma parcela crescente trabalha, sazonalmente, como assalariados, a fim de complementar o mínimo necessário à subsistência. Nesse processo de exclusão, os filhos dos pequenos proprietários (que Gaiger insiste em tratar de camponeses), sem as condições necessárias, deixam de seguir a tradição da família e empregam-se como assalariados, quando encontram trabalho. Caso contrário, lutam contra o desemprego, o subemprego e a exclusão, entrando na luta do MST. Esse é o caso típico dos trabalhadores do Sul do País. Nesse sentido, a luta é explicada pelo retorno ao passado, cuja imagem permanecerá, ulteriormente, como referência, fundamentada do movimento. Por isso, insistem na volta do processo familiar que não só atende aos interesses econômicos, mas também, na qualidade de unidade produtiva, constitui uma entidade sociocultural vital para os camponeses, sendo o espaço de referência para sua integração na vida social e para dar sentido às possibilidades e às opções individuais.

Sob esse prisma, tem-se que os pequenos proprietários encontram as diversidades da política agrícola no crédito rural, encontram dificuldades para manter sua propriedade e, por vezes, perdem suas terras para o grande proprietário, ou se endividam de tal forma junto aos às instituições financeiras que ficam impossibilitados de continuar suas atividades. Os interesses deles não são os mesmos dos produtores de cana, de soja e dos reis do gado. Quando sentam para negociar com o governo, estão mais próximos dos "sem-terra", dos assentados e dos assalariados. Ser agricultor familiar não significa desprezar as formas coletivas de produção, por meio do cooperativismo, e pretender atingir a formação da agroindústria, podendo até comercializar diretamente seus produtos em supermercados. Portanto, nada impede que esses pequenos proprietários se tornem empresários rurais.

Giovanni Nicolini (1980, p.39-45) dá um novo perfil à propriedade familiar, estabelecendo que esta se funda na comunhão tácita familiar, onde deve prevalecem a afetividade e o respeito ao comando de seu chefe, ${ }^{12}$ que deve estar atento à produção, para o consumo e bem-estar desta, como tam-

12 Embora se fale em "chefe de família", constitucionalmente essa figura não mais existe, em virtude da equiparação dos direitos e deveres do casal, na administração da sociedade conjugal (art. 226, $\S 5^{\circ}$ ). Além disso, grande parte das famílias brasileiras é chefiada, efetivamente, por mulheres. 
bém para o escoamento da produção excedente para o mercado cuja renda deve também promover o bem-estar da família.

Agricultores familiares (sem força de trabalho assalariado) ou pequenos produtores com pouca terra e poucos empregados podem e devem se constituir empresários agrários, conforme o asseverado no Capítulo 1. José Sidney Gonçalves, em entrevista à revista Panorama Rural, parte do pressuposto de que é preciso inserir a pequena agricultura no agronegócio por meio de políticas públicas, e a produção de escala deve se especializar no mercado financeiro (cf. Costa, 2006). Segundo o agrônomo, a agropecuária brasileira deve se basear na complementaridade entre a atividade rural de escala e adensada (de pequenos espaços). Fazer avançar a agricultura familiar e trazê-la para o agronegócio seria uma das medidas pertinentes para tanto, assim como a capacitação do pequeno produtor. Lembra o pesquisador que Milton Santos ${ }^{13}$ já dizia que a técnica não existe sem a política e que a agricultura familiar não prosperou porque nunca foi estruturada num projeto nacional em longo prazo. Conclui afirmando que a agricultura familiar merece a mesma prioridade conferida à agricultura de escala, para formar cadeias de produção com agroindústrias, agregar valores e diversificar os produtos numa visão agroecológica.

Xico Graziano (1999, p.43), na defesa dos pequenos proprietários, assim se manifestou: "Errado não está ajudar os sem terra a melhorar de vida. Errado está em proteger os assentados rurais, discriminando os pequenos agricultores já existentes no País. Que são, é necessário dizer, a maioria absoluta”. O que, para este trabalho, soa altamente preconceituoso, uma vez que o interesse do Estado deve ser isonômico e por não refletir a verdade, pois a ajuda é equânime e muito pouca para todos.

Somam-se, hoje, no Brasil, no mínimo, 4 milhões de produtores familiares. Este é o paradoxo: embora em grande número, esses produtores, na maioria dos casos, são muito marginalizados e sentem-se excluídos das políticas públicas rurais. Aqui está o drama dos "com terra".

Os pequenos proprietários, qualificados como produtores familiares, representam a grande esperança para o desemprego no Brasil. ${ }^{14} \mathrm{~A}$ agricul-

13 Um dos maiores geógrafos humanistas deste País.

14 Em sua tese de doutorado, esta pesquisadora trabalhou referida questão tanto na esfera da agricultura familiar decorrente da reforma agrária quanto nas outras formas. 
tura familiar, sucesso em outras nações e ainda desprezada no Brasil, poderia alimentar o País e eliminar as tensões no campo, refletindo na melhoria do urbano.

Ricardo Abramovay (1994, p.102) alerta que pequeno produtor rural, no sentido econômico, não pode ser qualificado como agricultor familiar:

Aquilo que se pensa tipicamente como pequeno produtor é alguém que vive em condições muito precárias, tem um acesso nulo ou muito limitado ao sistema de crédito, conta com técnicas tradicionais e não consegue se integrar aos mercados mais dinâmicos e competitivos.

A propriedade familiar deve ser necessariamente ampliada, por meio dos programas de políticas públicas, para se inserir no mercado econômico. Abramovay refere-se - acredita-se, no plano jurídico - ao produtor minifundiário ou àquele que vive abaixo da linha de pobreza e que carece urgentemente do auxílio estatal, para deixar essa situação. São muitos nessa condição. São estes que integram a lista da insegurança alimentar. Portanto, devem receber incentivos especiais, como crédito rural subsidiado, orientações de plantio, incentivo para formação de cooperativas, organizações associativas motivadas pelos organismos públicos, desconcentração de poder da União e centralização de comando pelas prefeituras. Alterações legais dessa ordem motivariam a criação de grupos que fortaleceriam o interesse familiar e seu crescimento. A eles não é suficiente só a integração no Bolsa Família; são cidadãos que merecem outras alternativas.

Não obstante o apoio conferido pelas leis ao agricultor familiar, muito do que está escrito não procede fora do papel. Insiste-se que a luta pela instalação real da agricultura familiar deriva da movimentação popular e da insistência em construir espaços democráticos de organização, como são hoje as cooperativas, as discussões nos assentamentos e, até mesmo, os protestos para liberação dos créditos rurais.

A opção pelo modelo familiar justifica-se por sua capacidade de geração de empregos e renda e pelo baixo custo de investimento. Manoel José dos Santos (2000, p.229) atribui a esses fatores as razões para o futuro da empresa familiar, acrescidos dos seguintes argumentos que, articulados num todo, primam em firmar esse modelo como instrumento de sobrevivência e democracia dos povos: 
1. agricultura familiar é capaz de reter a população fora dos grandes centros urbanos;

2. é fator fundamental na construção de alternativa de desenvolvimento;

3. sua capacidade de produzir alimentos a menor custo e, potencialmente, com menores danos ambientais, impulsiona o crescimento de todo entorno socioeconômico local.

A falta de incentivos a essa forma de exploração tem gerado a marginalidade dos jovens trabalhadores, envolvendo-os em diferentes formas de violência.

Para que os trabalhadores possam integrar o desenvolvimento pleno, é preciso que se unam, ou na forma de manutenção da exploração individual, mas com sua produção comercializada sob a forma de cooperativa, ou, ainda, que mantenham todo o processo de empreendimento dentro da exploração coletiva.

Muito embora contribuam insistentemente para a produção alimentar, é real que apenas poucos financiamentos, destinados à agricultura, foram destinados aos grupos familiares, apesar de haverem produzido muito mais, com menos recursos.

A agricultura é, portanto, o principal agente propulsor do desenvolvimento comercial e, consequentemente, dos serviços nas pequenas e médias cidades do interior do Brasil. Basta criar incentivos à agricultura para que, pelo seu efeito multiplicador, obtenha-se resposta rápida nos outros setores econômicos; é o desenvolvimento com distribuição de renda no setor rural que viabiliza e sustenta uma qualidade de vida do setor urbano.

As políticas de apoio à agricultura familiar devem, inclusive, contemplar aquelas atividades com grande potencial de geração de renda e ocupação, como o artesanato rural, o turismo rural, a industrialização, formas de lazer, como o pesque-pague, o hipismo rural, o enduro de montanhas e outras. Outro elemento que deve estar integrado às políticas fundamentais de fortalecimento da agricultura familiar diz respeito à priorização de investimentos públicos, para garantir serviços de pesquisa, experimentação, difusão, assistência técnica e extensão rural, comprometidos com a sustentabilidade e adaptados aos meios de produção familiar.

O grande sucesso da produção familiar demonstra-se na capacidade de organização dos produtores, que podem se unir para clamar por políti- 
cas públicas, como devem se unir para comercializar e gerir a produção, a diversificação agroecológica e planos de desenvolvimento local. Esse conjunto de proposições deve, no entender de Manoel José dos Santos, estar articulado a uma política de produção de alimentos e soberania alimentar da população brasileira, como parte integrante da estratégia de desenvolvimento (idem, p.234).

Por sua vez, a gestão da unidade produtiva precisa ser considerada como exercício prático da democracia. Se todos os participantes têm um papel e uma função no processo produtivo, têm direito a tomar parte nas decisões e nos resultados. Para isso, é preciso valorizar o trabalho das mulheres, dos jovens, construindo relações sociais de gênero, geração e etnia igualitárias e solidárias, no cotidiano dos trabalhadores. É preciso entender que só se concebe agricultura familiar a partir de uma economia solidária. Nesse sentido, a gestão coletiva de produção apresenta-se como uma alternativa concreta pela participação prática da cooperação. Assim recomenda Manoel José dos Santos (2000, p.73):

1. Agricultura familiar só se viabiliza a partir de uma economia solidária combinada com o uso de novas tecnologias e diversificação dos meios tradicionais de produção.

2. As formas coletivas de produção e comercialização se apresentam como alternativas concretas mediante a prática de cooperação, associativismo e parceria.

3. Desenvolvimento rural sustentável passa necessariamente pela garantia de documentação do uso da terra, o que também contribui para a construção da cidadania da população rural.

Para que o grupo familiar encontre seus objetivos, é necessário que, desde cedo, organize-se nas discussões coletivas. O trabalho prospera na forma cooperativa, onde todos se unem, participam das discussões e deliberam sobre os destinos de seus produtos. A forma de exploração coletiva também é bem-vista na agricultura familiar: todos têm seu lote, mas cultivam em grupo o produto, definindo as estratégias e, como frisa o MST, sem cercas.

Esse mecanismo de trabalho, em princípio, facilita a produção, pois a extensão de terras é contínua, bem maior; a compra de sementes e outros tratos da terra é feita de forma conjunta, com facilidades pela quantida- 
de; todavia, a operacionalidade fica difícil, pois o assentado, ou o pequeno produtor, muitas vezes, sente-se, como ensina Maria Conceição D'Incao (1995, p.54), oprimido e não dono do seu pedaço de terra, o que lhe dificulta o trabalho e a aceitação das regras do assentamento.

Em viagem pelo oeste de Santa Catarina, foi possível observar que a cooperativa de produção é o mecanismo ideal para os que já são proprietários, enquanto a forma coletiva, se aceita pelo grupo, é ideal para os assentados. Nos assentamentos onde o MST tem força e eficiência no comando, sabese que a exploração conjunta funciona porque os dirigentes são práticos em comandar desde a ideologia até o funcionamento prático do plantio.

O despertar cooperativista é uma - se não a maior - forma de sobrevivência do pequeno produtor. Muito utilizada em países desenvolvidos, a cooperativa promove o cidadão em todas as situações. Comercializando os produtos, vendendo equipamentos, prestando assistência técnica, organizando reuniões, facilitando a aquisição de gêneros de necessidade, a cooperativa ensina a solidariedade e promove o futuro mais simples e eficaz.

Os assentamentos, único espaço para a inclusão dos sem-terra, na sociedade global, oferecem uma oportunidade ímpar de desenvolver novas estratégias tecnológicas e novas formas de organização e de reprodução social. As associações, os condomínios de produção rural e as pequenas cooperativas especializadas são garantia de eficiência, racionalização e poder de barganha. São condições de competitividade, afirmação, autonomia, cidadania e identidade (Guellen, 1998, p.225).

No Brasil, os assentamentos são decorrentes do processo de reforma agrária, por meio da desapropriação, ou, ainda, resultantes do processo administrativo de legitimação, ou regulamentação de terras. Esses mecanismos criam postos e condições de trabalho, de inclusão de cidadania e de qualidade de vida, com baixo custo; oferecem a oportunidade ímpar de acrescer novos produtos para os consumidores, dinamizando as economias locais e regionais, como já revelaram estudos sobre os municípios e as regiões beneficiados por esse processo.

O assentamento é uma forma muito mais peculiar do processo de desapropriação, que desencadeia essa forma de trabalho rural, todavia, como há necessidade de se permanecer na terra por quatro anos, o legitimado também permanece nessa situação provisória, que não o torna proprietário nesse período de carência, mas revela, novamente, a situação de um traba- 
lhador rural que exerce a atividade agrária dentro de um perfil diferenciado do empregado rural, mas com características de proprietário, sem o ser juridicamente.

Os assentamentos são núcleos de trabalho rural, com amparo governamental e com política agrária especial, que, quando bem orientados, tornam-se núcleos de progresso e bem-estar dos trabalhadores.

Os números expressivos dos assentamentos e do sucesso de suas produções pouco rendem matéria jornalística. Os índices de produtividade desses assentamentos não são mensurados para contabilizar a vitória da reforma agrária. O resultado disso é que nada se conhece da realidade socioeconômica nas áreas reformadas. Essa enorme lacuna faz refletir sobre o fato de que a esquerda brasileira sempre lutou contra o latifúndio, pouco se importando com o resultado prático do desenvolvimento agrário. É como se a reforma agrária se esgotasse na desapropriação das terras e no assentamento imediato dos trabalhadores rurais, ou como se a luta política contra o latifúndio estivesse finalizada no momento da divisão da terra. Daí em diante, sabe-se lá o que vai acontecer. No máximo, o que se ouve são os discursos vazios de que "não adianta apenas dar a terra, é preciso oferecer condições de produção".

Pode-se interpretar, em princípio, que o assentado passa de "sem terra" para "com terra", não importando mais sua luta, doravante. Pensa-se que estão esgotadas as ambições e sonhos do trabalhador, que passa a ser um pretenso proprietário, sem subordinação, sem salário, um agricultor. Mas todos sabem que, na prática, as coisas não acontecem de forma salutar num processo tão rápido. $\mathrm{O}$ trabalhador não dispõe de rendas, é tutelado pelo governo federal, ou por projetos estaduais, por meio dos convênios com o Incra, e sua emancipação, para ser reconhecido como proprietário, pode superar o prazo legal de dez anos. Nesse tempo, ele está trabalhando não como empregado, nem como proprietário; é como se fosse arrendatário, mas não o é, pois não paga nada ao governo, ao contrário, recebe crédito subsidiado, assistência técnica, apoio governamental, desde a ponte que cai até a falta de água ou a cerca derrubada. Que figura jurídica representaria esse trabalhador? Recebendo a cessão de uso, pelo período provisório de dez anos, qual é a garantia desse trabalhador que, por meio de trabalho, muito trabalho, venha adquirir essa terra? E se sua "vocação pela terra" não corresponder às expectativas, permanecerá o indivíduo sob a tutela do governo? E se não 
der certo e tiver que deixar a terra, que segurança e proteção que terá esse trabalhador? O que fazer com esse tempo trabalhado? É preciso ir além da divisão de terras, para que o trabalhador possa deixar a sua condição de "sem terra" e transformar-se em "com terra". A emancipação dos assentamentos é o sucesso dessas pessoas, também espécie do gênero trabalhador rural, que, para atingir não só os ideais de produtividade, mas também a realização plena da função social, requerem uma política voltada para os assentamentos, que só irá emancipar após dez anos de existência. Os dados dos assentados não são muito otimistas com relação à situação da condição desse trabalhador. Os números demonstram que 40\% dos assentados são analfabetos ou semianalfabetos; aproximadamente 33\% dos beneficiários apresentam idade acima dos 48 anos; apenas $67,5 \%$ dos assentados rurais são oriundos do meio rural. São informes relevantes e preocupantes. A situação desses trabalhadores demonstra que, mesmo assentados, estão muito aquém da condição de cidadãos.

Pela força e pressão do MST, o governo, meio encurralado, cede às pressões e incrementa os assentamentos por meio das desapropriações das terras invadidas. Novas famílias recebem seus lotes. Individualmente, sua vida apresenta uma melhora considerável. De errantes, ou favelados, tornamse pequenos agricultores. Um chão para morar, uma terra para cultivar. Existe uma melhoria, sem dúvida, para o trabalhador que deixa a situação do desemprego e passa, ao menos, a reivindicar uma situação social com um pouco de igualdade. Os assentamentos derivados do MST, ademais, contam com o apoio incansável da Igreja Católica, de ONG, movimentos internacionais, da sociedade e de seus adeptos, e, acima de tudo, com a força da liderança do MST, que conduz com racionalidade e organização o assentamento. Este, como é a praxe, é trabalhado de forma coletiva, e as decisões são propostas e aprovadas pela maioria. Grande parte dos assentamentos tem, ao menos no estado de São Paulo, a produção organizada em cooperativas, que cuidam desde o plantio até a agroindustrialização do produto. Da mandioca no pé ao polvilho no supermercado, ainda com a inscrição na embalagem "Produto da Reforma Agrária".

Acredita-se ser esta uma grande vitória não só desses árduos trabalhadores, mas também um exemplo para todos que clamam por uma vida melhor. A luta pelo trabalho, realizada desde a plantação até a produção comercializada - portanto, a atividade agrária -, completa seu ciclo. 
O Censo Nacional dos Assentamentos (Leite, 2004) (realização da Universidade de Brasília (UnB) e do Incra), sem dúvida, é uma expressão de que a reforma agrária tem legitimidade, o que não isenta tal processo de tensões, lutas e disputas entre projetos políticos diferentes. Aos meios, é importante deixar posto que os comentários pertinentes aos dados apresentados transpuseram a unanimidade de mostrar que os assentados foram considerados trabalhadores rurais e que estes cresceram satisfatoriamente no decorrer dessa política de incremento da reforma agrária.

Os assentados, apesar de não serem qualificados juridicamente como senhores de terra(!), não serem ainda proprietários e apenas, sim, concessionários do governo federal, trazem a marca de agricultores familiares. Se bem cuidados e recebendo apoio técnico e administrativo - e, aqui, não se fala de protecionismo, e, sim, de direitos -, estes poderão vir a ser os pequenos proprietários futuros, responsáveis pelo desenvolvimento da nação.

O assentado é alguém que surge de uma dificuldade, passada em sua vida, sob o ponto de vista sociojurídico, e que, ao término do conflito, não consegue obter sucesso no seu escopo, acabando por se inscrever no projeto da reforma agrária, via Incra, via Banco da Terra ou ainda em movimento social. Conseguido seu propósito, ele se alimenta de um sonho e parte para sua terra recebida como lote e aí pretende edificar seu futuro. Dependendo da origem, o assentado recebe seu lote e parte para a exploração individual ou conjunta. Se for do MST, provavelmente irá para lotes coletivos e estará sempre discutindo sua metas em assembleias; se integrar assentamentos onde os estados possuem institutos de terra, estes, certamente, apoiarão os assentados, com prestação de assistência técnica e financeira, discussão de produção, curso em parceria e outras salvaguardas.

Belisário dos Santos Júnior (1998, p.4) considera que o assentado traz contra ele um instrumento maléfico, gerado pelo defensor da cultura do latifúndio que atribui a este a insigne de preguiçoso e indolente. No entanto, relegados às terras menos férteis e mais longínquas, marginalizados das políticas públicas, sem acesso ao crédito, os agricultores familiares sobreviveram. Muitos foram condenados, em sua grande maioria, à exclusão social. Tornaram-se boias-frias ou migraram para as grandes cidades, onde não encontraram condições dignas de vida. O País, em trágica ironia, parecia pequeno. 
Os tempos, no entanto, mudaram, e, conforme Santos Júnior (1998, p.5), parte dos agricultores familiares já estabelecidos, de forma criativa, responde aos desafios. Afinal, como já demonstrou a ONU, pela FAO, a agricultura familiar é, na maioria dos casos, mais produtiva e capaz de gerar mais empregos. Pela primeira vez, o Brasil registra que há uma volta para a terra - estão voltando os assentados e os que buscam no campo os anseios de uma vida melhor. Os primeiros estão constituindo-se em agricultores familiares, apesar do preconceito, estão produzindo e integrando a comunidade, melhoram suas condições de vida e contribuem para o desenvolvimento local e, consequentemente, com suas produções, melhoram a vida da coletividade.

Não é uniforme essa reação em todo o Brasil. É sabido que, em muitos locais, os assentamentos não prosperam por falta de incentivos e desânimo dos trabalhadores. Mas o sucesso de muitos projetos faz que os assentados, em fase de construção, exijam apoio e se espelhem nos modelos produtivos e nas técnicas, sobrevivendo à luta.

Não se pode traçar um perfil único ante as diversidades regionais brasileiras. Os assentados ganham uma identidade, ainda em construção, mas que pode dividi-los em grupos dos assentados filiados ao MST e nos demais inscritos no processo de reforma agrária.

O jornal $O$ Estado de S. Paulo publicou o resultado de uma pesquisa feita pelo Serviço de Inteligência do governo federal, nos acampamentos do MST, em que se concluiu que a maioria de seus integrantes tem entre $25 \mathrm{e}$ 44 anos, $90 \%$ não concluíram o $1^{\circ}$ grau (dos quais $22 \%$ são analfabetos), $76 \%$ são agricultores e $86 \%$ são filhos de agricultores, enquanto $60 \%$ nunca trabalharam nas cidades. A pesquisa comprova que a maioria dos assentados é de capitalistas e que são em número de cerca de 60 mil acampados. A maioria é católica, e $51 \%$ são filiados ao PT, ${ }^{15}$ sendo o restante apartidário. Somente $17 \%$ dos filiados já foram agricultores com terra, $3 \%$ foram posseiros, e a maioria dos assentados que já teve terra as vendeu por motivos financeiros, de saúde ou familiares; muitos se queixaram que já foram expulsos de suas terras. Outros 24\% disseram que querem a terra para produzir e sustentar a família, 9\% afirmaram que querem trabalhar em cooperativas, e $8 \%$ sonham

15 Hoje, pelas manifestações contra o governo, tendo-se em vista o não cumprimento das promessas de reforma agrária, pensa-se que o índice seja bem menor. 
com um lugar para morar. O objetivo dos assentados é deixar a condição de empregados e ver a terra dividida, e grande parte confirmou que o MST recebe ajuda de várias organizações não governamentais internacionais (Luis \& Marques, 2000).

Apesar de as condições não serem plenamente favoráveis, a desistência nos assentamentos é pequena, o que comprova a eficiência da reforma agrária, ao menos para sanar a fome de seus beneficiários, como geradora de empregos e de perspectiva para a população rural. O índice de abandono gira em torno de $21 \%{ }^{16}$

A reforma agrária é o principal instituto para democratizar a terra. Diminui desigualdades, desconcentra a terra e promove o cidadão. Mas, num país de diversidades, como o Brasil, deve-se pensar que muitos estão na terra sem as devidas instruções, para um manejo sustentável, produtivo, racional e promotor de função social. A construção da vida sobre o chão deverá criar condições de sobrevivência e de desenvolvimento de uma nova comunidade. Um fator de grande colaboração é que, na opinião do jornalista Tomazela (2001), todos os assentamentos que dão certo têm moradia, escolas e alimentação, tudo de uma forma organizada. Assim, as políticas públicas têm de ser mais amplas, tomando a cidadania como um todo.

$\mathrm{O}$ assentamento, produto de reforma agrária, reduto de agricultura familiar, constitui-se em estratégia para aumento de produção interna, reveste-se da capacidade das comunidades de aumentar sua própria renda e sua segurança alimentar. Para Gordilho de Anda (2003, p.56) (representante do Comitê da America Latina e Caribe na FAO), o combate à fome passa pelo fortalecimento da agricultura familiar, com venda direta dos produtores para os mercados locais. A vitória dos assentados é o pagamento de uma grande dívida social ao acesso à terra. O programa de apoio, a reforma agrária, a agricultura familiar e as intenções de segurança alimentar vêm lavrados no Programa Nacional dos Direitos Humanos, bem como no Programa Estadual de Direitos Humanos de São Paulo e da maioria dos Estados brasileiros. Mas, como no papel as letras estão escritas de forma pacífica, revela-se que, na prática, a luta é mais árdua. O Direito se busca, mas a cidadania se constrói. Os direitos humanos são expressão da cidadania, são direitos de todos ao reconhecimento da dignidade intrínseca do ser,

16 Dados obtidos no IBGE. 
independentemente de qualquer julgamento e condição, e, por isso, são vistos como direitos universais. Não basta conhecer os direitos, é fundamental construir a sociedade democrática com acesso a todos, de forma democrática, baseada na liberdade, na justiça e na igualdade. Portanto, a reforma agrária é condição para que o Brasil se propague democrático e justo. A ausência de cidadania no campo ou em qualquer outra situação implica a exclusão moral e social dos indivíduos. Excluir pessoas implica o não direito, a negativa do direito. Deixar pessoas à margem do processo político social e econômico é negar-lhes as garantias individuais fundamentais.

Nesse raciocínio, faz-se necessário promover o cidadão como um todo, dentro da perspectiva dos direitos humanos, e, no campo, essa situação perpassa pela reforma agrária e pela construção da agricultura familiar.

Afora o estado de São Paulo, outras localidades com realidades diferentes, inclusive históricas, trazem marcas do sucesso e do progresso trazidos pela agricultura familiar; os agricultores de Santa Catarina, do Rio Grande do Sul, alguns do Paraná, de certas localidades de Minas Gerais, um número mínimo do Nordeste comemoram o sucesso. Ao contrário, a região do Vale do Jequitinhonha, o árido nordestino, agricultores da maioria das áreas do Pará e da Amazônia padecem com a fome, a miséria, o raquitismo, a pobreza, a exclusão plena. Está-se, portanto, longe do Estado Social Democrático de Direito e dos direitos humanos. A soja, a cana e o gado não transmitem suas riquezas, a não ser a um grupo selecionado. Não se pretende, como já salientado, destruir as monoculturas, mas reduzir misérias e desigualdades, e o campo pode dar essas respostas para todas as regiões; basta boa vontade de a toda sociedade, cobrando e agindo em prol de todos.

A reforma agrária que se pretende é a que mude e descortine uma nova situação para o brasileiro, não importando se ela trouxe homens para o campo para plantar ou colher, ou se trouxe simplesmente para consertar tratores, ou mulheres para ser cabeleireiras, se para promover o turismo, ou se formou pessoas para cobrar os políticos de seus direitos, ou ainda se fez cidadãos que exigiram que, a cada cem hectares de cana, fosse plantado um de alimento a ser consumido. A reforma agrária que se quer é a mudança na vida dos que estão no campo. Mudança para uma vida bem melhor, o que assusta o segmento patronal. Muito embora, num primeiro momento, a reforma agrária seja apresentada como algo obsoleto, entende-se que essa política pública é eficaz e promotora de direitos à alimentação. Com ela o 
homem galga sua independência pelo seu trabalho e pela sua dignidade e cidadania. Além disso, reforma agrária é acesso à terra, minimização das concentrações de riquezas, direito constitucionalmente posto nos objetivos da Carta Magna brasileira.

A luta dos movimentos sociais para uma melhor distribuição da terra, em especial o Movimento dos Sem Terra, criação única hoje de oposição no Brasil, representa a bandeira de luta para o grande passo da reforma agrária e independe de seus métodos, ele é um grande avanço na democratização da terra e muitas melhorias já colheu para o povo oprimido e faminto deste País.

\section{O MST e a segurança alimentar}

De acordo com Manuel Andrade Correa (1980, p.74):

Os movimentos em defesa da terra são resultado da formação de classes, profundamente antagonizadas, face à concentração de renda e à diferença entre os níveis de poder, provocando, durante quase cinco séculos de colonização, atritos e lutas, ora sob a forma individual, entre senhor e escravo, entre proprietário e trabalhador; ora entre grupos sociais antagônicos, formados pelos proprietários de um lado e trabalhadores de outro.

O Movimento dos Sem Terra, no dizer de Varella (1998), tem características próprias, típicas dos movimentos sociais, desenvolvidos principalmente a partir dos anos 70, o que a teoria sociológica dos anos 90 classifica como novos movimentos sociais, em contraste com os velhos movimentos sociais, como o movimento operário, feminista etc.

Enquanto os antigos movimentos sociais baseavam-se em orientações instrumentais, orientações para com o Estado e organização vertical, com ideologias baseadas na doutrina "esquerda" versus "direita", "liberais" contra "conservadores", os novos têm, como características, "critérios de afetividade, relações de expressividade, orientações comunitárias e organização horizontal", com códigos não convencionais, fora da luta tradicional "operário" versus "burguesia" (Varella, 1998, p.226). 
Aponta Varella (1998, p.228) que os valores e as formas de atuação evoluíram com o rompimento dos valores políticos e culturais vigentes desde a revolução marxista, no início do século, o que permite o aparecimento de novas formas de solução de conflitos, fora do Judiciário, nem sempre fora do Estado, com a criação de organismos de mediação, como o Ministério Público, as defensorias públicas, os órgãos de defesa do consumidor, os conselhos e juizados de conciliação, com participação de secretarias de governo, ministros de Estado, de governadores e até do presidente, com mecanismos ainda não materializados no direito positivo, mas mais eficazes que estes.

O caso dos sem-terra deixa muito clara essa postura, pois percebe-se que parte dos conflitos envolve soluções advindas dos órgãos citados, não havendo a participação judicial, que, muitas vezes, pelo seu formalismo e tecnicismo jurídico, atrapalha, em vez de colaborar na solução dos casos.

O movimento social do MST deve ser considerado um movimento social significativo. Sem-terra é a denominação de um sujeito coletivo, criado durante o processo de estruturação do movimento. A qualificação como sem-terra pressupõe a consciência da comum situação de carência e de exclusão social que deriva do não acesso à terra e mesmo a condições dignas de existência, excluídos dos meios de produção, o que confere individualidade ao grupo.

As razões para o nascimento do movimento têm, como raízes, a luta histórica pela reforma agrária e o acesso dos trabalhadores aos seus direitos. $\mathrm{O}$ desenvolvimento do capitalismo e os governos militares, apoiados pelo capital estrangeiro, forneceram crédito rural subsidiado para as grandes propriedades, entregaram terras públicas para as grandes empresas, e, como consequência, vários trabalhadores rurais, meeiros e arrendatários foram excluídos da oportunidade de trabalhar a terra, para dela tirarem o sustento de suas famílias. A construção de barragens e a falta de incentivo e de política agrícola também contribuíram para o agravamento da situação, que eclodiu nas ocupações de latifúndios, em princípio, no Rio Grande do Sul, com apoio da Pastoral da Terra, da Igreja Católica. Em seguida, as ocupações começaram em Santa Catarina, São Paulo e Paraná, e foram ganhando espaço, até que, em 1984, consolidou-se o primeiro encontro do Movimento dos Trabalhadores Sem Terra, com este nome e com articulação, projetos e diretrizes próprias. 
Hoje, a entidade congrega milhares de membros, com estrutura própria, organização exemplar, dotados de ideal, trabalho e afinco na luta para redimensionar as terras brasileiras, promovendo o acesso dos trabalhadores a elas. Logicamente, não atinge todos os trabalhadores rurais não proprietários do País, que se contam aos milhões, até porque nem todos os que não têm terra identificam-se como integrantes do MST.

Acenando para que a reforma agrária seja uma luta de todos, o MST levou até as cidades a batalha para a democratização da terra. Além de melhorar e desenvolver o trabalho no campo, o MST promove a educação e a metodologia de ensino, relativas à questão agrária, promovendo cursos, palestras e encontros, sempre fortalecendo os ideais de persistência, luta e solidariedade, fundamentais no processo em que vivem.

A organização de trabalhadores em cooperativas permite o beneficiamento da produção e a racionalidade desta, privilégio anteriormente detido pela classe patronal.

O grupo, a cada dia, organiza-se mais, e seus méritos são visivelmente demonstrados, até nas questões jurídicas, haja vista o grande número de leis, com o objetivo de promover a melhor distribuição de terras, como o rito sumário (Leis Complementares nº 76/93 e nº 88/96), as alterações do ITR, regulamentação dos requisitos ao cumprimento da função social da propriedade, além do maior número de assentamentos realizados, embora, ainda, esbarre-se em algumas forças conservadoras.

Nesse contexto, pode-se concluir que o MST tornou-se um agente social novo, que propicia a recolocação na atividade agrária de milhões de trabalhadores rurais, anteriormente alocados à miséria, à fome e ao êxodo rural.

Não há que se falar que a reforma agrária é necessária e urgente para terminar com o problema dos pobres, miseráveis sem terra, mas é imprescindível para melhorar a condição de vida de todos os brasileiros, para democratizar a terra e o País, para minorar as diferenças socioeconômicas e para promover a justiça social.

Assim, o MST é um verdadeiro movimento social de grande amplitude e que, certamente, trará consequências sobre a organização e compreensão da sociedade brasileira como um todo. A instalação da luta em prol dos trabalhadores sem terra, com programas efetivos de reivindicação, traz, sem dúvida, a lume, o despertar de um novo trabalhador rural, cidadão empreendido em construir o bem-estar da classe, do País, assegurando a qualida- 
de de vida de toda a população. Isso é o que se ganha ao se resolver o problema do trabalhador rural. É o interesse difuso que ainda não foi percebido e que continua a ser tratado apenas como interesse coletivo.

O MST, politicamente, tem se unido à Confederação Nacional dos Trabalhadores da Agricultura (Contag), com o objetivo de alterar as reivindicações dos trabalhadores rurais, quer sejam eles empregados, quer sejam trabalhadores de outras espécies. A preocupação com as condições de miséria da maioria dos empregados rurais, que, além do desemprego, enfrentam situações de encontrar trabalho somente em épocas de safra, ficando à mercê de frentes de trabalho ou da fome, motiva a entrada dos sindicatos rurais a engrossar as fileiras do MST. Todos unidos poderão efetivar a reforma agrária, e o trabalhador deixará então a condição de empregado e se tornará assentado.

Para o MST, fica claro que não são todos os empregados que poderão se tornar assentados e que também não é este o desejo unânime dos trabalhadores. A preocupação é centrada nos que são explorados como força de trabalho e que vivem à margem do processo de cidadania. Todavia, o MST se preocupa também com o fato de que os empregados façam valer seus direitos sociais, trabalhando em consonância com os sindicatos. Justamente nesses pontos, o Movimento dos Sem Terra diferencia-se de todas as figuras jurídicas até hoje identificadas. O MST tem uma determinada organização em âmbito nacional, estimando-se em 4,5 milhões de famílias, localizadas em diversos acampamentos, em todo território brasileiro - uma grande maioria tem formação de militância, em cursos específicos, para isso. O MST conta, em sua estrutura, com cerca de 5.200 militantes profissionalizados, que atuam em assentamentos, cujas áreas de ocupação correspondem a mais de 7 milhões de hectares. Basicamente, são meeiros, boias-frias, desempregados da área rural - tanto pequenos produtores, que perderam suas terras em razão das várias políticas governamentais, como ex-assalariados.

É certo que o MST retoma questões debatidas há dezenas de anos no Brasil e, há tempos, no mundo, de uma maneira corajosa, em que não se pretende (como insistem muitos doutos preclaros) atingir uma propriedade determinada, nem praticar o esbulho. Protestam e não cometem crimes. Pretendem chamar a atenção da sociedade para a desigualdade rural, os sofrimentos, a miséria e a fome, em um país que tem em seu território uma das maiores extensões de terra do planeta. A força de sua luta traz o apoio 
internacional de entidades sérias de direitos humanos e governos democráticos preocupados em rebater o abuso e a exploração do homem. A Bélgica condecorou o Movimento pela sua atuação na luta pela reforma agrária, assim como outros países têm manifestado seu apoio: Alemanha, França, Itália, Espanha.

Em nível nacional, a jurisprudência tem reconhecido que o MST expressa a luta e o protesto pela reforma agrária. Em artigo publicado por esta pesquisadora, considera-se o assunto da seguinte forma:

A primeira grande vitória expressa foi por ocasião da sentença proferida na $8^{a}$ Vara Federal de Minas Gerais em 1995, quando então o juiz Antonio Francisco Pereira negou liminar de reintegração de posse contra "invasores" que adentraram as terras do DNER. Nesta sentença, o juiz proferiu: "não, os invasores definitivamente não são pessoas comuns, como não são milhares de outras que habitam pontes, viadutos e até redes de esgoto em nossas cidades. São párias da sociedade (hoje chamados excluídos, ontem descamisados) resultado perverso do modelo econômico adotado no País". Elencando uso dos mais diversos artigos constitucionais, o juiz autorizou a permanência dos invasores sob o fundamento de que "se eles não tiveram o direito de escolher como viver poderiam optar como morrer". (Maniglia, 1997, p.256)

Posteriormente, em decisão histórica, o Superior Tribunal de Justiça por

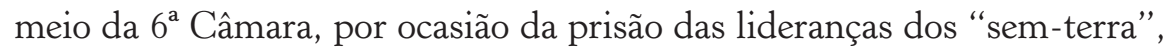
por unanimidade, discorreu que a atitude do MST não caracteriza esbulho possessório e que o País é responsável pela grande dívida social que se tem com os miseráveis afastados do bem da vida. Frisou o ministro Vicente Cernichiaro que a luta pela reforma agrária é um paradigma a ser cumprido. A demora de sua implantação gera reações nem sempre cativas, não havendo, portanto, esbulho possessório por parte do MST e não, consequentemente, crime, pois a conduta do agente de esbulho possessório é substancialmente distinta da conduta da pessoa com interesse na reforma agrária.

Particularmente, esta pesquisadora já havia adotado essa postura por ocasião da defesa de seu mestrado, em 1994, na USP, sustentando que a invasão não é crime, porque não complementa o quesito da culpabilidade na estrutura do crime, não havendo, portanto, culpa por quem a pratica, mas descaso governamental somado ao descumprimento da função social, não 
se caracterizando, assim, o delito. Felizmente, dois anos depois, o Superior Tribunal de Justiça argumentou na mesma linha.

Outrossim, outras muitas sentenças têm conferido ao MST o papel de sua luta por uma sociedade agrária mais justa, onde o trabalhador rural seja dignificado por seu trabalho. Opta-se por conferir ao MST o seu valor de agente social, em prol do trabalho rural neste País, ferido por sua história de desrespeito e injustiça aos que labutam nesse setor. Seus anseios são plenamente constitucionais, não se constituem em "quadrilha", como muitos querem qualificá-los, e se, por vezes, utilizam meios violentos, é porque a violência simbólica e estrutural foi utilizada anteriormente. Dessa feita, a luta pela reforma agrária tem importância social e econômica para uma parcela do contingente de excluídos, deslocado do campo para as periferias urbanas, para as quais o acesso à terra representa a única alternativa concreta de emprego produtivo, de geração de renda e fim da fome. Além disso, articulada com uma política de desenvolvimento territorial e uma complementação agroindustrial, a reforma agrária constitui também uma das poucas opções para a dinamização da economia do interior do País, das cidades de pequeno porte, que gravitam em torno da atividade agrária e de melhor condição de vida para os pobres do campo e das periferias.

Edson Teófilo (2002, p.39) afirma convicto a necessidade da reforma agrária como condição necessária para o desenvolvimento rural e a eliminação da pobreza. Segundo o autor, a relação entre pobreza, desigualdade de renda (e da riqueza) e crescimento assume importância fundamental para definir os elementos relevantes para a condução de políticas de desenvolvimento rural que atendam aos objetivos de promoção, de eficiência e equidade, e não apenas ao atendimento assistencialista de populações carentes.

Na reforma agrária, a conquista em matéria de cidadania e de desenvolvimento é dupla: de um lado, a população assentada, antes marginalizada, passa a ter acesso às políticas públicas, ganha reconhecimento social e político; de outro, os assentamentos e suas organizações passam, progressivamente, a ser levados em consideração pelos municípios, pelo comércio e pelas forças políticas locais, e passam a exercer um papel ativo na definição das políticas e dos investimentos públicos. De acordo com Teófilo (2002, p.56): "[...]redesenha-se, assim, em muitos casos, a ordem de prioridades estabelecidas pelos poderes locais. Investe-se socialmente no meio rural, propondo cidadania inclusive participativa nas decisões a serem tomadas". 
Nesse arranjo institucional, formam-se os agricultores familiares que, aos poucos, vão estruturando suas terras, sua produção, adequando-se aos mercados e cobrando as políticas aclamadas na Constituição. Em médio prazo, o Direito vai realizando sua missão, assegurando a efetivação dos direitos sociais. Com imaginação e destreza, os assentamentos vão formando mão de obra e alternativas diversas para o emprego que pode ser em atividades rurais, urbanas e turísticas. As formas associativas são as mais producentes, e cabe ao Estado ajudar a promovê-las.

Não obstante, por todas as razões aqui apresentadas, o MST tem um papel de relevância nessa luta contra a fome e a miséria, principalmente porque força e exige que o governo desempenhe seu papel na efetivação das políticas públicas de melhoria da vida dos povos rurais, quer na distribuição de terra, quer na luta contra a fome, quer na luta contra a miséria.

\section{Meio ambiente e segurança alimentar}

Os direitos humanos de terceira geração contemplam o direito ao meio ambiente saudável e à solidariedade. O Direito Agrário, em seu princípiomor da função social, estipula a preservação ambiental e a manutenção dos recursos naturais. Por sua vez, os recursos naturais, catalogados como bens ambientais de ordem natural e de importância vital para a humanidade, encontram-se, em sua maioria, no habitat rural. Ainda, a segurança alimentar fala em quantidade de alimentos, mas assegura a qualidade destes e preocupa-se com isso. Nesse emaranhado de conceitos, as conexões estabelecem-se de tal forma que se tem a certeza de que Direito Agrário, Direito Ambiental e segurança alimentar se inter-relacionam num eixo movido pelos direitos humanos, num complexo mecanismo que envolve produção agropecuária, precaução, técnicas agrícolas, leis, instituições e políticas públicas, que se voltam para o desenvolvimento sustentável.

O movimento ambientalista que envolve, hoje, estudos ligados à filosofia, psicologia, política e religião, precisa ser visto como uma revolução cultural, que implica uma profunda modificação da estrutura dominante. O ambientalismo está estreitamente ligado a uma nova tendência ética religiosa, voltada a recuperar a empatia das pessoas a viver o essencial (Livorsi, 2000). 
A preocupação com o meio ambiente cresce em todos os segmentos, e, muitas vezes, apesar da consciência da necessidade de se estabelecerem prevenções e reparações contra os danos ambientais, os danos contra a natureza constituem-se numa das mais sérias impunidades e numa grave violação aos direitos humanos. Esquivel (2005, p.108) alerta que não se pode pensar na preservação do meio ambiente sem se atentar para o consumo, para a solidariedade, para o respeito cultural, para os pobres, para o Estado, pois todos eles são direitos vinculados aos direitos econômico-sociais que, sem embargo, devem ser respeitados na sua íntegra.

Soares (2004, p.113) afirma que: "os problemas da pobreza e do meio ambiente podem ser evitados e sanados pela sociedade; não há falta de tecnologia que impeça sua superação; na verdade, os obstáculos são sociais, políticos e econômicos". As causas da degradação ambiental nos países são consequências das estruturas predominantes de poder, capitalista, socialista ou comunista. Com fundamento em Lutzemberg, Soares (2004, p.113) prossegue:

[...] o poder se utiliza de instrumentos, tecnologias, métodos e processos que geram dependência, ao concentrarem o capital e o poder de decisão. O mais grave é que esta postura é considerada sinônimo de progresso, a única alternativa para a humanidade alcançar produtividade e eficiência.

No meio rural, na ânsia da produtividade, os prejuízos ambientais têm se avolumado com o avanço das fronteiras agrícolas, o uso abusivo de insumos e agrotóxicos, a destruição das florestas, as práticas degradadoras e o uso desordenado das águas que causam, em última análise, armadilhas à exclusão social inerente à busca da eficiência produtiva (da competitividade), qualquer custo, o que exige a recuperação da antiga noção de desenvolvimento social e a propugnação de estratégias e políticas de apoio para grupos sociais e não apenas para o êxito mercantil de agentes individuais (Maluf, 2002, p.257-8).

A degradação ambiental que decorre do desenvolvimento econômico alcançado pelos povos do Primeiro Mundo trouxe consigo consequências indesejáveis, forçando a reorganização das sociedades para dar um equacionamento a uma nova ordem jurídica e social que contemple os efeitos maléficos de tais benefícios, os quais acabam por ser transferidos às sociedades 
não desenvolvidas, ou em desenvolvimento, a um elevado custo social que, em geral, não é mensurado economicamente, mas que se traduz em lucros para os degradadores (Cardoso, 2003, p.15).

A ânsia por progresso e a busca incessante pelo lucro das sociedades capitalistas e mesmo das demais provocaram no mundo o grande desastre ecológico e a perda de bens naturais, que se pensavam renováveis, o que gerou a busca de um novo caminho ambiental, impondo-se, sobre os que não causaram nem metade do dano, obrigações pesadas de rever suas ações ou até de não executar determinados comportamentos, tendo-se em vista as consequências danosas para toda a humanidade.

A norma jurídica passa, então, a ser o instrumento capaz de regular os interesses éticos, sociais, econômicos e políticos atinentes à matéria ambiental, visando reduzir as desigualdades entre os iguais. O Direito Ambiental passa a ser também um instrumento de intervenção da sociedade, por meio do poder público, nas questões econômicas e sociais. Esse Direito ocupa todo espaço globalizado, e as normas, embora de caráter nacional, devem estar em compatibilidade com os ditames internacionais.

Passa-se a tratar de interesses supranacionais e no, que se pertine à agricultura e à pecuária, observa-se um interesse particular, principalmente na produção de alimentos que serão consumidos pelo Primeiro Mundo. As normas ambientais recaem sobremaneira sobre os meios e a segurança dos produtos, com normas fitossanitárias impostas e regras de alto rigor ambiental. Instala-se, assim, a partir dos anos 90, uma nova teoria acerca da produção rural.

Contudo, o que foi colocado nos idos de 1970, pela Revolução Verde, permanece nos países em vias de desenvolvimento, e essa tecnologia é o método que garante a grande produção por meio de insumos, adubos e agrotóxicos. Dessa feita, estabelecem-se duas vertentes. Primeiramente, os alimentos para consumo da União Europeia devem estar dentro de regras (vistas no capítulo referente à segurança alimentar) que ambicionam a qualidade dos produtos, desde a origem das sementes até a mesa do consumidor; portanto, só se comprarão produtos agropecuários se os requisitos forem preenchidos. Assim, muita coisa tem mudado para satisfazer o comércio internacional. No entanto, no âmbito interno, a ausência de cuidados ambientais, a pobreza e a desigualdade social geram os danos irreversíveis ao meio ambiente, provocando um ciclo vicioso que empobrece o meio 
rural. A ânsia dos empresários em fazer crescer seus lucros derruba matas, polui águas, tira riquezas e sobrevivência dos pobres. Muito ainda precisa ser feito pelos Estados, pelos produtores e pela sociedade organizada.

É preciso reconhecer o que é apontado por Leila Ferreira (2003, p.79): "Toda atividade humana tem um custo ecológico a ela vinculado; esta consciência também enfatiza a necessidade de compreender a natureza holística da vida: a vida biológica, social e política". Assim, o objetivo é reduzir gastos ambientais e trabalhar com racionalidade, alterando a estrutura de poder concentrado, para que haja sustentabilidade nas produções, limites às grandes empresas na anseio por seus lucros e um Estado forte, que conduza o cuidado ambiental, sem dar primazia aos grandes grupos econômicos e sem estar sob as pressões feitas por estes sobre suas decisões no Executivo, Legislativo ou Judiciário.

No meio rural, a realidade ambiental é danosa. Dentre a busca das supersafras, o direito de paisagem, a produção de alimentos saudáveis, a preservação das reservas legais e das biotas têm prevalecido a exploração, a ocupação desordenada do solo, os conflitos por terra, o trabalho escravo e todas as outras sequelas já comentadas.

A agricultura moderna vive na obsessão da exploração extensiva das grandes superfícies, sem obstáculos, de rapidez mecânica, de execução de fortes investimentos energéticos, de adubos, de altos coeficientes, de biocidas e de exigências de produção numa base quase industrial. $\mathrm{O}$ mito do farmer americano tem sido responsável por profundas transformações do ambiente natural. A destruição das áreas de mata natural para aproveitamento conduz a modificações da fauna local ao suprimir as reservas de animais selvagens e ao eliminar os abrigos e poleiros das aves de rapina e dos pássaros; a silvicultura tem sido explorada tradicionalmente em regime de pilhagem; a destruição das florestas tem como principal objetivo a obtenção de madeiras e a monocultura impera (Mendes, 1977, p.177-8).

Equilibrar a produção para a população que cresce e preservar o meio ambiente, num primeiro momento, parece contraditório, porém já foi amplamente debatido que os alimentos podem ser produzidos em alta escala e que, mesmo assim, a fome continuará existindo, porque suas causas são outras. Assim, pensar no meio ambiente equilibrado para uma segurança alimentar é buscar um sentido ambiental que evite pobreza e marginalização, que não gere destruição e que não expulse o homem para as periferias 
das grandes cidades, para lá poluir, passar fome, produzir lixo e viver abandonado pelas políticas públicas.

A responsabilidade ambiental no meio rural é extensiva às cidades. Um primeiro ponto a ser tratado é o freio à migração. As cidades não comportam mais tantas pessoas; retê-las no campo, com trabalho e infraestrutura, é o primeiro passo para conter os dramas citadinos de meio ambiente. A formação de um novo ciclo de desenvolvimento rural pode gerar novos empregos. Sachs (2004, p.124) afirma que é um erro supor que os refugiados do campo que migram para as favelas e para os bairros periféricos das cidades transformam-se, automaticamente, em citadinos. Na visão otimista, as favelas funcionam como purgatórios. Tudo indica que o custo da urbanização dos que já foram arraigados no campo será muito mais elevado do que seria a geração de empregos e autoempregos decentes e a promoção do progresso civilizatório no meio rural.

Os serviços que empregam a população rural podem ser variados, como já salientado, e as reações ambientais devem ser controladas pelos municípios, o que é permitido pela legislação ambiental. Por meio dos planos do biodiesel, pelo turismo rural, pelo artesanato, pelo comércio em geral, pela agricultura familiar ou até mesmo pela pouca mão de obra utilizada na monocultura, é fundamental manter a população empregada no campo para fins de preservação da espécie humana e do meio ambiente. Os municípios devem zelar pela infraestrutura rural e propiciar a sustentabilidade orientada por políticas públicas ambientais, que empreguem as pessoas em seus locais, explorando as atividades culturais, inclusive. Um bom exemplo são as festas de rodeios que empregam pessoas, fomentam a criação de animais, o comércio e a cultura, rendem dividendos e, consequentemente, permitem que as pessoas tenham segurança alimentar, sem sair de seus habitats.

Mais do que números, é necessário desenvolver em todos os setores. Assim, pode-se dizer que desenvolvimento relaciona-se, primeira e preferencialmente, com a possibilidade de as pessoas viverem o tipo de vida que escolheram e com a provisão dos instrumentos e das oportunidades para fazerem suas escolhas (Veiga, 2006a, p.81). Esta é a segunda grande opção que o meio rural deve fazer para obter segurança alimentar: deve investir na sustentabilidade - aquilo que Veiga (2006a, p.112) chama de caminho do meio entre a produção e a preservação. O Direito Ambiental não pretende estancar a produção agrária, ao contrário, busca conciliar os institu- 
tos por meio da função social da propriedade, do manejo sustentável e das alternativas de meios de produção. A diminuição dos produtos químicos e fertilizantes com a troca de técnicas orgânicas, biológicas, biodinâmicas, e as chamadas agriculturas alternativas são respostas à melhoria do meio ambiente, da qualidade dos alimentos e um não aos propósitos da Revolução Verde. Caronbert Costa Neto (1999, p.302) estabelece que a meta da Revolução Verde, que propunha uma agricultura incorporada aos pacotes tecnológicos de suposta aplicação universal e que visava à maximização dos rendimentos dos cultivos, em distintas situações ecológicas, trouxe duras destruições ambientais, mas, de positivo, até certo ponto, pretendia emancipar o homem em relação aos limites impostos pela natureza, para que não continuasse a ser dependente da generosidade da mesma, e, além disso, os métodos agrícolas tradicionais não eram suficientes para ampliar a gama de produtos alimentícios, energéticos e industriais.

Os danos decorrentes do uso do pacote verde revolucionário, entretanto, podem ser assim definidos: degradação dos solos agrícolas, comprometimento da qualidade e quantidade dos recursos hídricos, devastação das florestas e campos nativos, empobrecimento da diversidade genética dos cultivares, plantas e animais, e contaminação de alimentos consumidos pela população (idem, p.304). Mesmo cientes de todas essas consequências, as práticas da Revolução Verde são repetidas, diuturnamente, no Brasil, calcadas na lógica do imediatismo e nas falsas seguranças afirmadas pelos grandes conglomerados multinacionais, que tornam seus compradores eternos dependentes da utilização de produtos químicos e, agora, das sementes, o que resulta na compra casada em que, comumente, os dois produtos (semente e herbicida) são oriundos da mesma empresa - o que, certamente, provoca a dependência econômica do produtor para com a mesma empresa, gerando os cartéis que impõem seus preços aos agricultores, os quais, na impossibilidade de manter seus débitos em dia ou sem a alternativa de preços, acabam por perder suas terras para essas indústrias ou para os grandes grupos econômicos. Nascem assim, também, a miséria, a pobreza, a fome e o êxodo rural.

A agricultura sustentável tem retorno econômico em médio e longo prazos, produz alimentos de alto valor biológico e tem elevado objetivo social, baixa relação capital/homem e alta eficiência energética (grande parte dela é reciclável) (idem, p.315). Seria tudo de bom para ser reinventado no campo. 
No entanto, outros estudos revelam que a agricultura sustentável representa mais um movimento social claramente promissor, porém ainda precário. Graziano da Silva (1999, p.63) questiona: mesmo nesse "admirável mundo verde alternativo", haveria mais justiça? Haveria boias-frias? Far-se-ia reforma agrária? Desapropriar-se-iam os que são improdutivos e os que não seguem as regras verdes? E os que insistissem em continuar poluindo? Para esse autor, é preciso pensar melhor sobre essas questões alternativas, firmadas no verde. Não é fazer volta ao passado, o que implicará vultosos investimentos, até com mais sofisticação, nem também aguardar longo prazo. A saída está no âmbito de políticas (paliativas, certamente) que sinalizem para práticas conservacionistas já disponíveis (e, todavia, quase nunca adotadas) e na indução de novas trajetórias científicas, e que não impliquem novas degradações da natureza.

Pensa-se que nada pode ser decidido isoladamente; deverá haver um conjunto de práticas que ambicione servir com qualidade a população, melhorando a vida num todo. Entretanto, dentro dessas práticas, não se pode mais permitir o desgaste ambiental contínuo, que vem se repetindo no Brasil de forma ilegal e prepotente, deixando a perplexidade imperar, quando se assiste a uma agricultura insustentável que destrói o solo, as reservas de água e a diversidade genética natural.

A agricultura que destrói a natureza destrói as chances de o homem viver melhor.

A agricultura é responsável por, aproximadamente, dois terços do uso global da água e é uma das principais causas de sua falta em algumas regiões. O desperdício está presente, e, se as práticas agrícolas fossem orientadas para sua conservação e não para a maximização da produção, o resultado seria mais benéfico. Por exemplo, as plantas poderiam ser irrigadas com sistema de gotejamento e culturas que requerem uso intensivo de água, como o arroz, e poderiam ser deslocadas de regiões com recursos limitados (Gliessman, 2005, p.52).

A problemática da água impede a vida saudável de milhões de pessoas neste País. Além da corrupção da indústria da seca que consumiu milhões para a não solução da falta de água no Nordeste, assiste-se à elaboração contínua de leis ambientais que, na prática, não combatem os problemas básicos de sustentabilidade. O econômico continua vencendo o ambiental e o social. 
Por um fim, é necessário repensar a agricultura que deve ser sustentável e produtiva para alimentar a crescente população humana (idem, p.53). Esse duplo desafio precisa de pesquisas, estudos, investimentos para se estabelecer a agroecologia. Muito embora, na lei de política agrícola, estejam presentes esses dispositivos, voltados para a pesquisa, assiste-se ao sucateamento da Embrapa ou verifica-se o destino de verbas para pesquisas da agricultura somente convencional que renda muitos dividendos.

O estudo da agroecologia abre as portas para o desenvolvimento de novos paradigmas da agricultura, em parte, porque corta pela raiz a distinção entre a produção do conhecimento e sua aplicação ao objetivo comum da sustentabilidade. Valoriza o conhecimento local e empírico dos agricultores, a socialização desse conhecimento e sua aplicação ao objetivo comum da sustentabilidade. (idem, p.54)

De acordo com as perspectivas e orientações da Cúpula Mundial da Alimentação, torna-se fundamental encarar o direito à alimentação dentro de uma meta que aborde a sustentabilidade plena, o direito ao alimento sólido e, também, a nutrição líquida, que inclui a água potável, que sofre duras e sérias restrições, quando não se pratica a agricultura correta. Segundo Gimenez (2002, p.66), para a eficácia de uma sustentabilidade, deve-se buscar o justo e o devido, como objeto da justiça ecológica, em amplitude universal e de temporalidade para o futuro. É preciso fundar uma dinâmica construída no desenvolvimento e na aplicação dos conteúdos de justiça e, em particular, dos direitos humanos fundamentais, firmados numa justiça que exija relação responsável entre o homem e seu meio.

"Sabe-se que os custos ambientais não são baratos, por isto, o capital resiste a assumi-los, assim como os custos sociais. Somente se pressionado 'de fora', por forças externas a ele, o mercado absorve estas parcelas" (Montibeller Filho, 2004, p.281). As pressões também podem funcionar como uma diminuição da produção e da empregabilidade, o que afeta o social. Assim, a luta e a pressão só obterão sucesso se forem racionais e em níveis nacional e internacional.

Os modelos agrícolas, o desenvolvimento, o consumo, as inovações tecnológicas pesam, inter-relacionam-se na busca de produção alimentar, segurança e nutrição, e, ainda hoje, é preciso refletir sobre outros fato- 
res, como o modismo alimentar, o desperdício e as pesquisas sobre a nutricionalidade dos alimentos e os fatores de riscos a que estão expostos os consumidores.

Um bom exemplo da imposição dessa lógica de mercado e de tecnologia no campo ambiental são os alimentos transgênicos, que fazem parte do que se denominam organismos geneticamente modificados (OGM), impostos pelas empresas de sementes, sementes estas que não se reproduzem e conferem às empresas que as vendem o monopólio global sobre o seu comércio e sobre a sua propriedade intelectual, fazendo que os produtores, além de serem compradores contínuos, vejam-se obrigados a pagar royalties sobre cada safra comercializada, bem como a comprar o pesticida específico que essa semente demanda (Scotto et al., 2007, p.45).

Sobre o aspecto da segurança alimentar, encontra-se que as plantas transgênicas são vistas como uma panaceia para muitos problemas contemporâneos: fome, má nutrição, meio ambiente. Por outro, encontram-se avaliações opostas: a difusão das plantas transgênicas entendidas como ameaça à conservação e ao controle de recursos genéticos e como tal o equilíbrio do ecossistema e à segurança alimentar de milhões de pequenos produtores, uma ameaça também à qualidade alimentar dos consumidores afluentes e um golpe final do sistema de direitos exclusivos de propriedade à sobrevivência do conhecimento tradicional e dos recursos genéticos como patrimônio comum. (Pessanha \& John, 2005, p.1)

A discussão sobre os transgênicos decorre da dúvida de fazerem eles mal ou não aos consumidores e se devem ou não ser comercializados livremente. Sobre esse tópico, são úteis as palavras de Nutti \& Watanabe (apud Pessanha \& John, 2005, p.125):

O fato de um alimento geneticamente modificado ser substancialmente equivalente ao análogo convencional não significa que o mesmo seja seguro, nem elimina a necessidade de se conduzir uma avaliação rigorosa para garantir a segurança do mesmo, antes que sua comercialização seja permitida. Por outro lado, a não constatação da ES (equivalência substancial) não significa que o alimento geneticamente modificado não seja seguro, mas que há a necessidade de se prover dados de maneira extensiva, que demonstrem sua segurança. 
O estudo dos transgênicos recebe o beneficio da dúvida e este permite a comercialização do produto, dada a incapacidade de comprovar os efeitos negativos do seu consumo à saúde humana. Em decorrência da incerteza e contrariamente à posição norte-americana, muitos países preferem aderir ao princípio da precaução, no que se refere à liberação dos transgênicos no meio ambiente e ao consumo humano. O Brasil, mesmo adotando em sua legislação o princípio da precaução, liberou, por questões meramente de satisfação dos jogos do poder, a comercialização desses produtos.

Os transgênicos, chamados de sociais, são aqueles que poderiam atender às necessidades das populações de baixa renda e à otimização da sustentabilidade da agricultura, e auxiliar na redução da degradação do meio ambiente. Evidentemente que esses produtos são, segundo Rodrigues \& Arantes (2004, p.94), aqueles que não interessam aos grandes grupos econômicos e cujo desenvolvimento deveria ser feito por instituições públicas.

Ante os riscos apresentados, devem-se avaliar os benefícios e malefícios, com o objetivo de acabar, de uma vez por todas, com a fantasia de que os transgênicos acabariam com a fome do mundo. Riechmann (2002, p.105) é categórico ao afirmar que a fome e a desnutrição severas não são problemas técnicos, mas de natureza político-social. A fome não é causada pela falta de terras ou de alimento, mas pela falta de acesso ao alimento e de fontes de renda em momentos críticos. Os transgênicos não resolverão os problemas porque a fome do mundo não é a escassez de comida, mas a escassez de democracia.

O modismo da alimentação, as dificuldades de tempo e o estresse têm sua influência no sistema de segurança alimentar e, por consequência, na produção de alimentos com baixa qualidade, que resultarão em obesidade ou desnutrição. Aqui estarão reunidos tanto os pobres quanto os remediados e os ricos. Fala-se daquilo que foi chamado "sociologia da alimentação", em que a alimentação humana envolve aspectos psicológicos, fisiológicos e socioculturais, sendo um fenômeno de grande complexidade que envolve a discussão da relação do homem com os alimentos sob diversos ângulos, inclusive na esfera jurídica (Proença \& Poulai, 2007, p.165). É um tema abrangente que aqui será resumido com base nas funções sociais do alimento, o qual se estende desde a alimentação do trabalhador (se come ou não na empresa, se tem tempo ou não para se alimentar, se tem ou não tíquete para almoço), até se tem ou não o suficiente para comer. 
A relação da alimentação com o indivíduo se reflete nos mais diferentes momentos: na sua vida social, em comemorações, festas, na escola, nas refeições diárias. Tudo está interligado aos tipos de comidas e bebidas que vão influenciar na segurança, ou não, alimentar das pessoas. O Direito atua nessa relação como agente protetor dos direitos humanos à saúde e à alimentação e está presente no Código do Consumidor, no controle das publicidades de bebidas, alimentos e remédios, e nas medidas fitossanitárias.

Essas mudanças na vida dos cidadãos trazem, como característica, a questão de hábitos, e a segurança alimentar estará presente ou não, o que dependerá do padrão de vida de cada um. Envolvem a questão econômica e também histórica e social, como a alimentação feita em fast-foods, em restaurantes self-services (venda a quilo), produtos industrializados, transgênicos, a ingestão de bebidas alcoólicas, ingestão de salgados em troca de refeições, ou a busca por produtos orgânicos, por consumo vegetariano, por carnes selecionadas, produtos lights e diets. Os Estados têm criado, para a satisfação das populações mais pobres, os restaurantes populares, com refeições a preços bem módicos. São pouquíssimos, e a ideia precisa ser mais bem incorporada, mas é um passo inovador.

Estas tendências criam a possibilidade de uma imensa diversificação dos alimentos, com o surgimento de novos produtos e com a possibilidade de identificação dos produtos de matéria-prima agrícola, aumentando seu valor agregado. $\mathrm{Na}$ realidade, estão sendo permanentemente criadas novas concepções sobre alimento, que passam a responder a diferentes necessidades do homem na alta modernidade. Em suma, estas tendências apontam para a personalização da comida no nível do consumidor final. A nova safra de produtos agroalimentares, provavelmente, será produzida por empresas em permanente atualização tecnológica, que acompanham as tendências do mercado e introduzem novos processos responsáveis pelo estado de ebulição em que parece encontrar-se no mundo agribusiness. (Castro, 1998, p.179-80)

Passa-se, então, a pensar na qualidade dos alimentos, e as exigências multiplicam-se, principalmente em nível internacional. Os produtores brasileiros estão submetidos às regras internacionais de cuidados de produção, o que envolve o meio ambiente, provocando alterações de hábitos e costumes. Os produtos orgânicos ficam em alta e ganham preços salgados 
e podem seduzir não só os pequenos produtores, mas também os grandes empresários. ${ }^{17}$ Os produtos naturais, vindos da floresta amazônica, fazem sucesso nos cosméticos e na produção de bijuterias, exibindo que a origem destes vinculam-se à preservação ambiental e são oriundos, em sua maioria, de economia solidária, o que agrega valor social. A madeira vinda do reflorestamento sustentável mostra que é possível explorar de forma correta, e isso ocorre porque muitos países exigem os selos de que esses produtos foram elaborados com critérios de função social: econômicos (rentabilidade do empreendimento ambiental, redução de danos, conservação da fauna, recuperação da mata, proteção da biodiversidade) e sociais (foram respeitados os direitos dos trabalhadores, o bem-estar das comunidades e a promoção destas) (Bezerra, 2004b). Essas certificações promovem os povos das florestas e garantem melhores condições de vida e o verde ambiental.

A rastreabilidade do gado é outra forma de garantir segurança alimentar, exigida pelo comércio internacional. O chamado Sistema Brasileiro de Identificação e Certificação de Origem Bovina e Bubalina (Sisbov) funciona como controle na produção das carnes, acompanhando a carne do pasto ao prato e, agora, também emitindo certificados de qualidade, o que, obviamente, agrega valor ao produto (Franco, 2002).

De maneira geral, todos os produtos exportados têm de aceitar as regras impostas pelo comércio internacional, que visa, hoje, à melhor qualidade dos produtos.

As regras jurídicas seguem as previsões ambientais que controlam a atividade agrária, o respeito ao meio natural, as operações produtivas, incluindo o turismo, os projetos e obras e todas as atividades ligadas à agricultura e todos os projetos sujeitos à evolução. O que clama uma maior intervenção da Administração na gestão de recursos. (Miguel, 1993, p.366)

Outros projetos estatais têm se voltado para a situação da desnutrição, principalmente no Nordeste. Os problemas ambientais, que lá são mais

17 A família Balbo, na região de Sertãozinho/SP, é referência na produção de açúcar, chocolate solúvel e café orgânicos, voltados para a preocupação ambiental e a função social. Seus produtos, denominados Native, dominam os melhores mercados europeus. A família dispõe de 13 mil hectares, conforme vídeo disponibilizado a esta pesquisadora e de acordo com diferentes reportagens publicadas nas revistas Globo Rural e Panorama Rural. 
graves, necessitam de intervenções de políticas públicas mais acentuadas na área ambiental, como contaminação de águas, de alimentos, uso indiscriminado de gorduras, açúcares, refrigerantes, o que provoca a obesidade, afora a falta de renda ou a presença dela muito baixa (Castelo Branco, 2003, p.109). É importante destacar que, nessas intervenções de promoção de melhoria de vida dos homens nordestinos, há a presença forte da Igreja Católica, o enfrentamento das raízes culturais que promove uma alimentação inadequada, a desinformação sobre a importância dos alimentos, a precariedade de sanidade e de acesso à água de qualidade, que também estão sendo vencidas pelos trabalhos da sociedade civil, dos movimentos sociais e das atuações governamentais.

Por fim, é preciso lembrar que, apesar da fome e da miséria presentes no Brasil, o desperdício faz parte do cenário, colaborando para agravar a situação desses miseráveis e tornando-se num acinte perante aqueles que mendigam um pedaço de alimento nas portas das residências, nas ruas ou nas instituições beneficentes.

As perdas começam nos plantios, quando os produtores já condenam suas safras a uma baixa produtividade, pelo uso inadequado de insumos e termina na alta taxa de lixo das residências, já que, por questão cultural, muitos brasileiros acabam jogando fora uma parte considerável de produtos alimentícios, seja por não saberem extrair deles toda a sua capacidade nutricional, seja por absoluto esbanjamento à mesa. (Gianella Junior, 2002, p.15-7)

O Estado peca pela falta de infraestrutura, permitindo que grande parte das safras de grãos colhidos no Centro-Oeste seja perdida, ao longo das estradas, pela deficiência dos transportes. A falta de locais ideais de armazenamento ou o descontrole de abastecimento trazem a perda de alimentos que se tornam sem condições de consumo, por descaso dos órgãos governamentais. Forma-se então o que foi chamado de "ralos agrícolas", em que milhares de toneladas de alimentos são desperdiçadas ante os milhares de pessoas que passam dias sem alimentos. Faltam, mais uma vez, organização e interesse estatal na promoção de um ambiente que acolha o homem como parte integrante deste. 



\section{CONSIDERAÇÕES FINAIS}

O término de um trabalho representa, muitas vezes, a alegria de uma missão cumprida. Não deixa de ser o caso desta pesquisa que, em fase conclusiva, apresenta os dados colhidos nos meses pretéritos. Não obstante serem os dados não muito alvissareiros, aponta-se que, de modo geral, o quadro da fome está em momento de regressão. A sociedade começa seu processo de vislumbre ante os problemas de ordem social e, até de um modo egoístico, passa a se preocupar com os que carecem de uma vida digna. Sabe-se que o não alento para os que têm fome terá como resposta o desassossego dos que desfrutam das benesses econômicas.

A comunidade internacional consagrou a segurança alimentar como um dos direitos humanos fundamentais. A Cúpula Mundial de Alimentação, em Roma, em 1996, estabeleceu como meta o ano de 2015 para reduzir pela metade o universo de pessoas que passam fome no mundo. É verdade sabida que essa meta não será alcançada; em que pesem os esforços que estão sendo realizados para tal fim, são 840 milhões de pessoas em inseguridade alimentar. Isso representa um flagelo real moralmente inaceitável para um mundo que consagra como direitos humanos a solidariedade e a paz social.

A segurança alimentar é a garantia, a todos os seres humanos, de acesso físico e econômico a alimentos básicos, necessários para uma vida ativa e saudável. Para conseguir tal intento, faz-se necessária uma multiplicidade de fatores, dependentes de instituições, como o Estado, movimentos sociais, organizações não governamentais e a sociedade como um todo, na busca por políticas públicas que intervenham em temas como a pobreza, saúde, educação, frentes de trabalho, geração de empregos, sustentação do 
pessoal no campo, tecnologia, pesquisas, apoio imediato aos que têm fome. Mas, sobretudo, é necessário pensar que a alimentação é um direito, e não um favor do Estado para os que não têm o que comer. Se é direito, deve estar ao alcance de todos, e todos devem desfrutar dessa norma, e o Estado deve garantir o acesso à alimentação não só em quantidade suficiente, mas também em qualidade, a fim de se completar a sustentabilidade da vida.

Durante as leituras iniciais, no preparo deste livro, já havia uma quase certeza de que seria árduo trabalhar com o tema da segurança alimentar num mundo egoísta, onde as pessoas buscam seus interesses particulares, onde as leis são feitas, muitas vezes, para satisfazer a jogos políticos e que, frequentemente, não são cumpridas; onde o dinheiro arrecadado da sociedade civil não é disposto para os fins sociais e a definição de bem comum é substituída pelo bem de um grupo político. No entanto, algo de intrigante havia nessa questão. O material disponibilizado sobre o tema reunia ensinamentos da ordem econômica, da Sociologia, da Medicina e da Nutrição, e, à luz do Direito, somente parcos trabalhos sob a mira do Direito Internacional. E, aqui, então, foi apresentada a reunião de múltiplos trabalhos interdisciplinares para construir essa visão jurídica da segurança alimentar, sob a égide do Direito Agrário e dos direitos humanos.

A segurança alimentar está focada na produção de alimentos seguros, que possam ser disponibilizados a toda a população. Produzir alimentos decorre de uma atividade agrária, tutelada pelo Direito Agrário: ter segurança alimentar é um direito fundamental. Portanto, a trilogia Direito Agrário, direitos humanos e segurança alimentar completa-se e fundamenta-se num princípio basilar, que é a efetivação da justiça social, a qual, para ser lograda, deve fundamentalmente existir numa democracia plena, em que o Estado privilegie a dignidade do ser humano e oferte as políticas públicas necessárias para o seu intento.

Dessa feita, o Direito Agrário deve estar presente em todos os Estados, constituídos ou não como agentes de segurança alimentar. Nos primeiros, o controle sobre a produção e sobre os mecanismos da atividade agrária sustentável deve ser realizado por leis que estipulem o manejo correto da terra, a qualidade dos produtos, o que produzir, a oferta e o controle para o mercado interno, e sobre as vendas dos produtos exportados. Nos segundos, onde impera a inseguridade alimentar, o papel do Direito Agrário deve ser mais rígido: devem ser estabelecidas leis que cuidem da produção, do meio 
ambiente rural e, sobremaneira, da divisão do solo, com políticas que impeçam a concentração fundiária responsável pelo agravo da miséria do campo.

O Direito Agrário, como ramo jurídico, sempre existiu na prática e estruturou-se como ciência autônoma no mundo, em 1922, quando perdurou uma longa situação de insegurança alimentar na Europa, em decorrência da Primeira Guerra Mundial. No Brasil, passou a ser considerado ciência, por disposição constitucional, em 1964, pela Emenda Constitucional n ${ }^{\circ} 10$, mas, até o presente, não foi integrado como matéria obrigatória nos cursos de Direito, apesar dos grandes esforços das entidades agraristas, o que traz um efeito altamente negativo para a conscientização dos problemas rurais à luz do Direito e vem influenciar, quase sempre, a proclamação de sentenças judiciais desconectadas da realidade, com sentimentos de dominação herdados da época colonial. Existe ainda um grande temor pelo Direito Agrário quando este cobra a função social da propriedade, e seu descumprimento ocasiona a desapropriação.

O Direito Agrário, sem fundamento, representa, na visão obsoleta de muitos, uma ameaça ao direito de propriedade e, consequentemente, uma ameaça aos grandes negócios. Portanto, seu estudo não deve ser obrigatório e, quando lecionado, deve apenas tratar daquilo que é pertinente aos institutos vinculados aos contratos e ao crédito, deixando de lado o que realmente provoca a desigualdade, a fome, as injustiças advindas da concentração de terras. Foi demonstrado que há muita terra nas mãos de poucos e muitos com pouca terra ou, ainda, os que não têm terra e não têm alimento e que, um dia, estiveram no campo, quer como proprietários, quer como trabalhadores, e lá formaram sua vida e sua identidade e dela foram expulsos por uma economia perversa acobertada pelo Direito. Esse Direito consagrou o interesse dos grandes proprietários, como os grandes heróis responsáveis pelas grandes safras e lhes deu a insígnia de proprietários produtivos não passíveis de desapropriação para fins de reforma agrária. Na prática, esses produtores em nada colaboram para a segurança alimentar do País, pois seus produtos são, em sua maioria, destinados ao mercado externo.

A atividade agrária é o cerne do estudo do Direito Agrário, e essa atividade pode ser exercida por proprietários ou não, o que permite dizer que a empresa agrária é o instituto que exerce a atividade agrária, que pode ser de origem patronal ou familiar, e que ambas estão voltadas para a produção de alimentos, já que os primeiros, via de regra, trabalham para o mercado ex- 
terno, e os segundos, para o interno, abastecendo as populações com produtos da cesta básica, com verduras, frutas e carnes, além de outros produtos de consumo regional.

Em todo o Primeiro Mundo, em especial na Europa, o Direito Agrário tem importância vital e está construído sobre a égide de dois princípios básicos: função social da propriedade e justiça social. Nesses países, a associação desses princípios é clara e precisa, sendo fundamental sua ação para corroborar a efetividade da segurança alimentar.

No Brasil, o Direito Agrário ainda patina sobre a concentração fundiária que acarreta uma grande turbulência no setor rural - hoje, um grande violador de direitos humanos. As legislações agrárias são muitas na proteção do cumprimento da função social, que abarca a produtividade, o trabalho digno e a preservação ambiental, mas sua efetivação não se dá a contento, em razão das pressões econômicas.

Em suma, o Direito Agrário é um grande instrumento de controle da produção agrícola, o que favorece substancialmente a segurança alimentar dos povos. É instrumento contra a opressão da concentração fundiária e, assim, pode evitar a pobreza e abrir novas frentes de trabalho que se incorporarem em seu rol novas atividades como agrárias. Todavia, deve ser conduzido como instrumental de interesse social e não como facilitador de grupos econômicos. Para tanto, o Estado deve promover as políticas públicas compatíveis com os objetivos estabelecidos na Carta Constitucional. Caso não o faça, deve a sociedade clamar por essas alterações.

Os direitos humanos foram consagrados, mundialmente, ao longo da História, tornando-se marcos de desenvolvimentos dos países, após 1789, com a Declaração dos Direitos do Homem e do Cidadão. Constituem-se em direitos fundamentais, positivados, geralmente, nas constituições dos Estados cujo objetivo é garantir as necessidades básicas da pessoa humana, para que esta viva com dignidade. A dignidade é o centro propulsor desses direitos que, por não estarem bem organizados, provocaram o desencadeamento de uma Segunda Guerra Mundial, que motivou, ao seu término, o segundo grande documento de caráter global, que foi a Declaração dos Direitos do Homem, assinada em 1948, que formalizou a posteriori uma teoria não unânime entre os juristas sobre as gerações de direitos humanos que motiva três grandes blocos: os direitos civis e políticos, de primeira geração; os direitos econômicos, sociais e culturais, de segunda geração; e os 
de solidariedade, que trabalham com os interesses coletivos, chamados de terceira geração.

$\mathrm{Na}$ verdade, esses direitos são interligados, e a ausência do cumprimento de um direito acarreta outras tantas violações, que desencadeiam um processo de cunho nacional, ou até mesmo internacional, envolvendo vítimas de diferentes segmentos sociais. O meio rural tem sido cenário constante de violações de direitos humanos que afetam as três gerações. $O$ trabalho escravo, o trabalho infantil, a desnutrição, a miséria, as degradações ambientais, os conflitos de terra, a morte dos que lutam por justiça rural formam um sucedâneo de ilícitos jurídicos, sob a tutela do Direito Agrário, pois todos eles envolvem a atividade agrária e o imóvel rural, corolários desse ramo jurídico.

São apresentados trabalhos que provam a interligação do Direito Agrário e dos direitos humanos, cuja base fundamental se estabelece na produção dos alimentos, na preservação ambiental e na segurança da dignidade do homem, principalmente por ser a atividade agrária a manutenção da preservação da vida e da espécie humana. Mas, lamentavelmente, o meio rural no Brasil é o campeão de desmandos legais, é o grande vilão desrespeitador das normas mais simples de proteção aos direitos humanos. Não que o direito aí não tenha penetrado com regras, mas como resultado de uma opressão histórica, permitida por um Estado que se omite perante as reais mudanças que devem acontecer.

A segurança alimentar deve ser provida por um Estado que, na sua responsabilidade de guardião das garantias individuais, deve oferecer a democracia, em sua exaustão, para seus governados, assumindo a responsabilidade pela efetivação dos direitos humanos. A segurança alimentar como direito à alimentação adequada é meta a ser cumprida pelo Estado, que, na impossibilidade de fazê-lo, deve buscar no âmbito internacional ajuda para o seu cumprimento.

No mundo, a segurança alimentar é pauta dos países desenvolvidos e integra a agenda política desde a Primeira Guerra Mundial. A partir da criação da ONU, foi criada a FAO, para discutir políticas de abastecimento, para pôr fim à fome e à miséria do mundo. Por muito tempo, pensou-se que a preocupação fosse com a produção dos alimentos, que estes pudessem faltar, e o mundo poderia perecer pela ausência de comida. Todavia, a tecnologia aperfeiçoou-se e descobriu-se o mais grave: que a fome no mundo 
é decorrência da ausência de recursos financeiros para adquirir produtos alimentares. Em outras palavras, a fome é decorrência da ganância dos ricos, das políticas dos países desenvolvidos no comércio internacional, da falta de solidariedade, da ausência do Estado que toma o lado dos grandes grupos econômicos para negociar favores. A miséria é fruto das corrupções políticas, principalmente onde a democracia é fraca: as oportunidades são desiguais, os salários são baixos, e o povo não se organiza para exigir do Estado seus direitos básicos. O Brasil tem melhorado, lentamente, seus índices de desenvolvimento, porque decidiu criar mecanismos de ajuda aos que passam fome. O Bolsa Família é um programa dentre os muitos que existiram e ainda caminham para tentar recuperar as pessoas que mal se alimentam. É uma prática paliativa que não altera as estruturas e que não provoca mudanças radicais, portanto resume-se a uma assistência emergencial. O resgate da dignidade dos pobres perpassa pela colaboração da sociedade, pelas mudanças econômicas, pela discussão daqueles que podem lutar por mudanças.

A criação de órgãos e leis, como a que foi feita no ano de 2006, para assegurar a segurança alimentar não significa muito. Há tantas leis descumpridas, a própria Constituição é descumprida, sem que grandes coisas aconteçam. Os poderes devem estar atentos para a efetivação, e a sociedade civil deve se organizar para cobrar in totum, do Legislativo, do Judiciário e do Executivo, políticas, leis, cumprimento, fiscalização para a efetivação da erradicação da fome no País. O modelo da União Europeia pode ser um referencial para as mudanças, e o Brasil tem potencial agrícola superior a qualquer país da Europa ou até mesmo do mundo; assim, não seria difícil superar as metas contra a fome se, efetivamente, alterações na infraestrutura do País fossem realizadas.

De Josué de Castro a Betinho, da Medicina à Economia, perpassando pelo Direito, a preocupação com a fome vem sendo discutida, mas não resolvida. O Estado é formado pela comunidade, por Estados-membros e municípios. A sociedade civil tem feito sua lição, e os movimentos sociais clamam por mudanças estruturais e dão sua cara a bater, porque, neste País, reivindicar direitos que ferem interesses dos grandes ou dos que se acham donos do poder é caso de polícia e não de política pública. Torna-se mais fácil equilibrar as forças, distribuindo-se cestas básicas, do que fazer reforma agrária com política agrícola. É mais simples incentivar e dar dinheiro aos 
ricos para que eles plantem, para vender para o exterior e incentivar a entrada de dólares no País, do que promover a agricultura familiar, que planta o que o brasileiro bebe e come. Se faltar alimento para os que têm dinheiro para comprar, importa-se da Argentina.

A ausência de uma meta do Estado faz que a atividade agrária não seja planejada, seja ao acaso, seja dependente das commodities, seja vinculada aos preços estabelecidos pelo governo, seja inconstante, sem promover o homem do campo e o meio rural. Os danos ambientais são decorrentes dos estragos da ambição humana, e seus reflexos estão presentes também na cidade. Sem dinheiro para o consumo de produtos de qualidade, o cidadão come o mais barato, torna-se obeso, torna-se um ônus para o sistema de saúde, acaba discriminado pelo governo e pela sociedade, e morre sem o direito humano à assistência. $\mathrm{O}$ mesmo se dá, quando consumindo produtos repletos de agrotóxicos, tem reações alérgicas e diarreias, e, internado, recebe o diagnóstico de "virose", para o médico não ter de pesquisar a razão de fundo ou para não comprometer um sistema que funciona numa ordem econômica.

Aos poucos, a consciência por uma alimentação saudável vem se consolidando. A discussão e a divulgação do Direito Agrário, o Código do Consumidor, as leis ambientais, o zelo e o modismo dos orgânicos, dos meios alternativos, das discussões, a força dos movimentos sociais, as alterações de comportamento da classe média podem, em conjunto, beneficiar os pobres.

A mudança precisa ser acelerada, as universidades precisam comprar essa luta de forma conjunta, assim como na década de 1990. Nessa tentativa de trazer a rediscussão do tema da fome para a universidade, sobretudo para o curso de Direito, é que se conclui este trabalho com a seguinte afirmação: se pelo menos as pessoas criticarem o texto ora apresentado, já será o suficiente para provocar a discussão, e isso indicará, em parte, que o objeto foi alcançado. Não se pretendeu invocar e sobrepor ideologias em xeque; a intenção primordial foi levar adiante o ideal de pôr a comunidade universitária na discussão de um tema que resgata a discussão do acesso aos alimentos, como um direito do cidadão - não daquele que tem poder de compra, mas de todos que são abrigados por um Estado que, em seus objetivos, propõe-se a oferecer dignidade.

Os mecanismos buscados ao longo deste trabalho fizeram que a pesquisadora transformasse, muitas vezes, as palavras sábias dos não letrados em 
conhecimentos revelados para a construção legal dos anseios do povo. A luta dos movimentos sociais são motores de mudança e de resistência aos opressores individualistas. A análise da história dos fatos agrários demonstra a pouca e triste evolução dos fatos reais rurais, mas, ao mesmo tempo, impulsiona os juristas para lutar pela efetivação dos direitos conseguidos nas cartas constitucionais. O constante vai e vem de leis, decretos e medidas provisórias demonstra o dinamismo do Direito. Pesquisadores da área devem repousar seus estudos nesse constante mudar, voltando-se sempre para a melhoria da condição de vida do ser humano que, na luta com o poder, deve, acima de tudo, ver priorizada a vida, a paz, a dignidade, a cidadania sem distinções de urbano ou rural.

É tempo de pensar no futuro das crianças e da natureza, na saúde dos velhos, no lazer dos homens que trabalham, na qualidade dos alimentos, nas nações que privilegiam a minimização da pobreza. A esses propósitos, o Direito Agrário e o Ambiental atendem e, por desfrute, realizam os direitos humanos em grande parte. Oxalá as gerações acadêmicas e os futuros detentores dos poderes nacionais se declinem e estabeleçam melhores condições de vida, melhores dias, um futuro mais terno e com paz para o mundo. 


\section{REFERÊNCIAS BIBLIOGRÁFICAS}

ABINAGEM, A. A família no direito agrário. Belo Horizonte: Del Rey, 1996.

ABRAMOVAY, R. Agricultura familiar e capitalismo no campo. In: STÉDILE, J. P. (Org.) A questão agrária hoje. 2.ed. Porto Alegre: Editora da Universidade Federal, 1994. p.94-104.

ALFONSIN, J. T. O acesso à terra como conteúdo de direitos humanos fundamentais à alimentação e moradia. Porto Alegre: Sérgio Fabris, 2003.

ALMEIDA, A. W. B. de. Quilombolas, quebradeiras de coco babaçu, indígenas, ciganos, faxinalenses e ribeirinhos: movimentos sociais e a nova tradição. Revista Proposta, Terra, Reforma Agrária e Direitos Territoriais (Rio de Janeiro), ano 29, n.107-8, p. 23-38, maio 2005/2006.

ALMEIDA, G. A. de. Direitos humanos e não violência. São Paulo: Atlas, 2001.

ALMEIDA, J. A. et al. (Org.) Turismo rural e desenvolvimento sustentável. 4.ed. Campinas: Papirus, 2000.

ALVARENGA, O. M. Política e direito agroambiental. Rio de Janeiro: Forense, 1977. Manual de direito agrário. Rio de Janeiro: Forense, 1985.

ALVES, F. Por que morrem os cortadores de cana? Disponível em: <http//www. pastoraldomigrante.org.br./folha150206html>. Acesso em: 26 abr. 2006.

AMORIN, C. Amazônia não atingirá metas da ONU. O Estado de S. Paulo, São Paulo, $1^{\circ}$ abr. 2007. p.A-28.

ANDA, G. G. de. Um novo contrato de cidadania. In: TAKAGI, M, et al. Combate à fome e à pobreza no meio rural. Campinas: Editora da Unicamp, 2002. p.15-31. Por um mundo bem alimentado. Globo Rural (São Paulo), ano 18, n.74, p.56-8, jan. 2003.

ANGEL, J. G. Metodologia y técnica de la investigación juridica. 2.ed. Bogotá: Temis, 1980.

APARISI, Â. Fundamento y justificacón de los derechos humanos. In: QUIRÓS, J. J. M. (Coord.) Manual de derechos humanos: los derechos humanos en el siglo XXI. Navarra: Aranzadi, 2006. p.155-72. 
ARRUDA, R. Conflitos de terra revelam um país que não saiu do século 19.0 Estado de S. Paulo, São Paulo, 24 jan. 2006. p.A4.

Não existiria nenhum Brasil vermelho sem recursos públicos. $O$ Estado de S. Paulo, São Paulo, 29 abr. 2007. p.A10.

ASBJORN, E. A realização dos direitos econômicos, sociais e culturais: o direito à alimentação adequada e a estar livre da fome. In: VALENTE, F. L. S. (Org.) Direito humano à alimentação: desafios e conquistas. São Paulo: Cortez, 2002. p.207-60.

ATTUCH, L.; PAIVA, A. P. Como é a fazenda mais cara do Brasil. Dinheiro Rural (São Paulo), ano 2, n.12, p.50-1, out. 2005.

AUDIER, J. Droit rural. 3.ed. Paris: Dalloz, 2002.

BALDEZ, M. L. A luta pela terra urbana. Revista de Direito Processual Geral (Rio de Janeiro), n.51, p.161, p.152-70, 1998.

BARBOSA, B. Brasil começa 2006 sem quebrar o ciclo da pobreza dizem os especialistas. Disponível em: <http://reporterbrasil.com.br/exibe.php?id==473>. Acesso em: 24 jan. 2006.

BERNARDES, M. Retrato da desigualdade: Manari - o Haiti é aqui. O Estado de S. Paulo, São Paulo, 23 jan. 2005. Nacional, p.A16.

BEURLEN, A.; FONSECA, D. L. da. Justiciabilidade dos direitos humanos à alimentação adequada: teoria e prática. In: PIOVEZAN, F.; CONTI, I. L. (Org.) Direito humano à alimentação adequada. Rio de Janeiro: Lumen Júris, 2007. p.175-85.

BEZERRA, J. A. Perfume que vem da mata. Globo Rural (São Paulo), ano 16, n.185, p.55-8, mar. 2001.

Rio de muitos frutos. Globo Rural (São Paulo), ano 19, n.220, p.57-9, fev. 2004a.

BEZERRA, J. A. Nossos bosques têm mais vida. Globo Rural (São Paulo), ano 19, n.226, p.20-5, ago. 2004b.

Atoladas até o pescoço. Globo Rural (São Paulo), ano 19, n.227, p.66-9, set. 2004c. 2004d.

A ciência do sapo. Globo Rural (São Paulo), ano 19, n.228, p.32-42, out.

Gente de fibra. Globo Rural (São Paulo), ano 21, n.253, p.80-6, dez. 2006.

BOBBIO, N. A era dos direitos. Trad. Carlos Nelson Coutinho. Rio de Janeiro: Campus, 1992.

Diário de um século: autobiografia. Trad. Daniela Versiani. Rio de Janeiro: Campus, 1998.

BOFF, L. Saber cuidar. Petrópolis: Vozes, 1999.

BONAVIDES, P. Curso de direito constitucional. 19.ed. São Paulo: Malheiros, 2006. BORGES, P.T. Institutos básicos do direito agrário. 11.ed. São Paulo: Saraiva, 1998. BRANDÃO, W. Produção repensada. Florianópolis: Anuário Ecológico, 2005. 
BRUM, A. J. Modernização da agricultura: trigo e soja. Petrópolis: Vozes, 1988.

BUARQUE, C. Prefácio. In: SACHS, I. Caminhos para o desenvolvimento sustentável. Org. Paula Ione Stroh. Rio de Janeiro: Garamond, 2002.

BURLANDY, L.; MAGALHÃES, R. Segurança, seguridade e direito: as diferentes faces da questão alimentar e nutricional. Disponível em: $<$ http://www. socialwatch.org/es/informeimpreso/pdfspanorbrasleirod2004-bra-pdf $>$. Acesso em: 23 abr. 2007.

CAFUNDÓ, J. C. O Brasil é verde. In: SYNGENTA PROTEÇÃO DE CULTIVOS LTDA. (Org.) A terra na terra: um livro sobre a agricultura e o trabalho com o solo. São Paulo: Books, 2005. p.47-59.

CALDAS, S. História viva e sonora. Globo Rural (São Paulo), ano 22, n.260, p.96101, jun. 2007.

CÁRDIA, N. Direitos humanos: ausência de cidadania e exclusão moral. São Paulo: Comissão de Justiça e Paz, 1995.

CARDOSO, A. R. A. A degradação ambiental e seus valores econômicos associados. Porto Alegre: Sérgio Fabris, 2003.

CARRERA, R. R. Derecho agrario para el desarrollo. Buenos Aires: Depalma, 1978.

CARROZZA, A. Localizzazione delle attivitá agricole e destinazzione pubblica e privatta delle terre all'agricoltura. Rivistta di Diritto Agrário (Milano), v.54, n.3, p.273-3, 1975.

Lezioni di diritto agrário: elementi di teoria generale. Milano: Giuffré, 1988. v. 1.

CASTELLON, L.; TARANTINO, M. Tragédia global. IstoÉ, n. 1727, p.50-3, 6 nov. 2002.

CASTELO BRANCO, T. Segurança alimentar e nutricional no nordeste do Brasil. Rio de Janeiro: Ceris, 2003.

CASTRO, A. C. Agrobusiness brasileiro e o papel do sistema de transportes intermodal. In: COSTA, L. F. et al. Mundo rural e política. Rio de Janeiro: Campus, 1998. p.175-94.

CASTRO, A. M. G. de. Direito do agronegócio: é possível sua existência autônoma? In: QUEIROZ, J. E. L. et al. (Coord.) Direito do agronegócio. Belo Horizonte: Fórum, 2005. p. 25-55.

CAVALCANTI, K. Viúvas da terra. São Paulo: Planeta, 2004.

CESARO, P. Turismo e agronegócio. Revista Agrolatina (Londrina), ano 1, n.2, p.5, ago./set. 2006.

CHIARA, M. de. 8 milhões de brasileiros deixam a baixa renda. O Estado de $S$. Paulo, São Paulo, 28 mar. 2007. Economia, p.B1.

CHOSSUDOVSKY, M. A globalização da pobreza: impactos das reformas do FMI e do Banco Mundial. Trad. Marylene Pinto Michael. São Paulo: Moderna, 1999. 
COMISSÃO DAS COMUNIDADES EUROPEIAS. Livro branco sobre a segurança dos alimentos. Bruxelas, 12 jan. 2000. Disponível em: <http://ec.europa. eu/dgs/health_consumer/library/pub/pub06_pt.pdf>. Acesso em: 17 jan. 2007.

COMPARATO, F. K. Direitos e deveres fundamentais em matéria de propriedade. In: CONGRESSO DE DIREITOS HUMANOS, 1., 1997, Brasília. (Anotações pessoais).

A a firmação histórica dos direitos humanos. 3.ed. São Paulo: Saraiva, 2003.

CONSELHO NACIONAL DE SEGURANÇA ALIMENTAR E NUTRICIO-

NAL. Princípios e diretrizes de uma política de SAN. Disponível em: <http:// www.planalto.gov.br/Consea/static/documentos/Outros/LivroConsea_ DocumentoReferencia.pdf>. Acesso em: 27 jan. 2007.

CORREA, M. A. Latifúndio e reforma agrária no Brasil. São Paulo: Duas Cidades, 1980.

COSTA, B. Tudo é agronegócio. Revista Panorama Rural (São Paulo), ano 6, n.122, p.16, dez. 2006.

COSTA, H. R. N. da. Agroturismo ou turismo rural: atividade agrária acessória. Revista de Direito Agrário (Brasília), ano 17, n.17, p.37-42, jan./jun. 2001.

COSTA NETO, C. Agricultura sustentável, tecnologias e sociedade. In: COSTA, L. F. C. et al. Mundo rural e tempo presente. Rio de Janeiro: Mauad, 1999. p.301-21.

D’INCAO, M. G.; ROY, G. Nós cidadãos aprendendo e ensinando a democracia. Rio de Janeiro: Paz e Terra, 1995.

DALLARI, D. de A. O renascer do direito. 2.ed. São Paulo: Saraiva, 1980.

DANTAS, F. Mais gente está empregada mas os salários estão cada vez menores. O Estado de S. Paulo, São Paulo, 8 jul. 2007. Economia, p.B7.

DE MATTIA, F. M. Especialidades do direito agrário. São Paulo, 1992. Tese (Doutorado em Direito) - Faculdade de Direito, Universidade de São Paulo.

Empresa agrária e estabelecimento agrário. Revista de Direito Civil Imobiliário, Agrário e Empresarial (São Paulo), v.19, n.72, abr./jun. 1995.

DINIZ, A. Correndo atrás da vida. Belém: Cejup, 1994.

DUPAS, G. O mito do progresso, ou progresso com ideologia. São Paulo: Editora Unesp, 2006.

DURAN, F. E.; PEREZ, J. L. Cambios en la concepción y en los usos de la ruralidad: del antropocentrismo productivista al ecocentrismo naturalista. In: UFRP. Desenvolvimento e meio ambiente: a reconstrução da ruralidade e a relação sociedade/natureza. Curitiba: UFPR, 2000. p.11-28.

ESQUIVEL, A. P. Los derechos econômicos, sociales y culturales, hoy. In: CAMPOS, G. J. B.; RISSO, G. (Coord.) Los derechos humanos del siglo XXI. Buenos Aires: Ediar, 2005. p. 105-10.

FACHIN, L. E.; SILVA, J. G. da. Comentários à Constituição Federal: arts. 184 a 191. Rio de Janeiro: Ederos Trabalhista, 1990. 
FALCÃO, I. M. O direito agrário no século XVI e o desenvolvimento rural brasileiro dos nossos dias. Revista do IAB (Rio de Janeiro), n.93, p.2-12, 2000.

FAUSTO, B. História concisa do Brasil. São Paulo: Edusp, 2002.

FELICIELLO, D.; GARCIA, R. W. D. Cidadania e solidariedade: as ações contra a miséria. In: GALEAZZI, M. A. M. Segurança alimentar e cidadania: a contribuição das universidades paulistas. Campinas: Mercados das Letras, 1996. p.215-31.

FERREIRA, L. A questão ambiental. São Paulo: Boitempo, 2003.

FERREIRA FILHO, M. G. A propriedade e sua função social. Revista de Direito Agrário (Brasília), ano 9, n.8, p.29-36, jul./dez. 1982.

Fim da queimada desemprega 5 mil na região. Comércio da Franca (Franca), p.3, 28 jun. 2007.

FÓRUM BRASILEIRO DE SEGURANÇA ALIMENTAR E NUTRICIONAL. Situação alimentar no mundo. Disponível em: <http://www.fbsan.org. br/mundo.htm >. Acesso em: 22 jan. 2007a.

Publicado decreto de reajuste do Programa Bolsa Família. Disponível em: $<$ http://listas.rits.org.br.mailman/listinfo/fbsan>. Acesso em: 23 jul. 2007b.

FRANCO, M. Rastreabilidade. Revista DBO Rural (São Paulo), ano 240, p.102, fev. 2002.

FREIRE, S. ONU vai analisar mortes no Maranhão. Folha de S.Paulo, São Paulo, 11 nov. 2006. Cotidiano Especial, p.C5.

FREYRE, G. Casa grande e senzala. 46.ed. São Paulo: Editorial Global, 2003.

GAIGER, L. I. G. Agentes religiosos e camponeses sem terra no sul do Brasil. Petrópolis: Vozes, 1987.

GARCIA, J. C. De sem rosto a cidadão. Rio de Janeiro: Lumen Júris, 1999.

GASQUES, J. G. Políticas específicas de combate à fome: mudanças na política agrícola. In: TAKAGI, M. et al. Combate à fome e pobreza no meio rural. São Paulo: Instituto da Cidadania, 2002. p.161-78.

GERMER, C. O desenvolvimento do capitalismo no campo brasileiro e a reforma agrária. In: STÉDILE, J. P. (Org.) A questão agrária hoje. 2.ed. Porto Alegre: Editora da Universidade Federal, 1994. p. 144-51.

GIANELLA JUNIOR, F. Os ralos agrícolas. Revista Família Cristã, ano 48, n.10, p.15-22, out. 2002.

GIMENEZ, T. V. El nuevo paradigma de la justiça ecológica. In: (Coord.) Justicia ecológica y protección del médio ambiente. Madrid: Trotta, 2002. p.59-67.

GIORDANI, J. A. L. Propriedade imóvel: seu conceito, sua garantia e sua função social na nova ordem constitucional. Revista de Direito Civil (São Paulo), n.69, p.47-55, jul. 1991.

GISCHKOW, E. A. M. Princípios do direito agrário. São Paulo: Saraiva, 1988.

GLIESSMAN, S. R. Agroecologia: processos ecológicos em agricultura sustentável. 3.ed. Porto Alegre: Editora UFRGS, 2005. 
GOMIDE, P. S. R. Fome atinge 14 milhões de pessoas no país diz IBGE. Folha de S.Paulo, São Paulo, 18 maio 2006. Disponível em: <http://www.folha.uol. com.br>. Acesso em: 19 maio 2006.

GONÇALVES, S. Da cidade para o campo. Globo Rural (São Paulo), ano 20, n.241, p.20-7, nov. 2005.

GRAZIANO, X. O paradoxo agrário. Campinas: Pontes, 1999.

GUELLEN, I. Reforma agrária: opção pelo modelo familiar de desenvolvimento. In: SILVEIRA, D. S. D.; XAVIER, F. S. (Org.) O direito agrário em debate. Porto Alegre: Livraria do Advogado, 1998. p.239-60.

GUIMARÃES, A. P. Quatro séculos de latifúndio. Rio de Janeiro: Paz e Terra, 1968.

HAJEL FILHO, R. A. B. Cooperativas de trabalho rural: a dicotomia entre o avanço e a fraude à lei. Franca, 2003. Dissertação (Mestrado em Direito) - Universidade Estadual Paulista.

HELENE, M. E. M. A fome de alimentos e justiça social. Revista Adusp (São Paulo), jul. 1995. Disponível em: <http://www.adusp.org.br.revista/03/r03a06. pdf>. Acesso em: 16 out. 2006.

HERKENHOFF, J. B. Para onde vai o direito? Porto Alegre: Livraria do Advogado, 2001.

HERNANDEZ, L. M. B. Derecho agrario: estúdios para una introducción. Zaragoza: Neo Ediciones, 1990.

HIRONAKA, G. M. F. Atividade agrária e proteção ambiental: uma simbiose possível. São Paulo: Cultural Paulista, 1997.

HOFFMAN, R. Estudos avançados: pobreza, insegurança alimentar e desnutrição no Brasil. Disponível em: <http://wwwscielo.br/pdf/ea/v9h24a07.pdf>. Acesso em: 17 ago. 2006.

HOLANDA, S. B. de. Raízes do Brasil. 26.ed. São Paulo: Companhia das Letras, 2005.

HUZAK, I.; AZEVEDO, J. Crianças de fibra. 3.ed. Rio de Janeiro: Paze Terra, 2000. IBGE - COORDENAÇÃO DE TRABALHO E RENDIMENTO. Pesquisa nacional por amostra de domicílios. Segurança alimentar. 2004. Rio de Janeiro: IBGE, 2006.

IPEA. Segurança alimentar e nutricional no Brasil. Brasília: Ipea, 1996. (Cadernos Comunidade Solidária, v.2).

IRANY, T.; RODRIGUES, K. Cai desigualdade social mas cresce trabalho infantil no país. O Estado de S. Paulo, São Paulo, 16 set. 2006. Nacional, p.A18.

KISS, J. Agricultor do asfalto. Globo Rural (São Paulo), ano 18, n.207, p.36-9, jan. 2003.

Bendito fruto. Globo Rural (São Paulo), ano 21, n.252, p.69-72, nov. 2006.

Porteira aberta para um bom negócio. Globo Rural (São Paulo), ano 22, n.259, p.40-53, maio 2007. 
LAFER, C. A reconstrução dos direitos humanos: um diálogo com o pensamento de Hannah Arendt. São Paulo: Companhia das Letras, 1988.

Prefácio. In: ALVES, J. A. L. Os direitos humanos como tema global. São Paulo: Perspectiva, 1994. p.XXVI.

LAMARCHE, H. A agricultura familiar. 2.ed. Campinas: Editora da Unicamp, 1997.

LARANJEIRA, R. Propedêutica de direito agrário. São Paulo: LTr, 1975.

Propedêutica do direito agrário. 2.ed. São Paulo: LTr, 1981.

Direito agrário. São Paulo: LTr, 1984.

O direito agrário como ciência no Brasil. In: (Coord.) Direito agrário brasileiro. São Paulo: LTr, 1999. p.251-93.

LAVINAS, L. Exptionality and paradox in Brazil: from minimum income programs to basic income. In: Congresso da Bien - Basic income european netwok, 2004, Barcelona. Anais eletrônicos... Disponível em:

$<$ http://www.etes.ucl.ac.Be/BIEN/FILES/Paper/2004lavinas.pdf>. Acesso em: 12 jan. 2007.

LEITE, S. et al. Impacto dos assentamentos: um estudo sobre o meio rural brasileiro. Brasília: Nead; São Paulo: Editora Unesp, 2004.

LIBERATO, A. P. G. Reforma agrária: direito fundamental. Curitiba: Juruá, 2006.

LIMA, R. M. de. Direito agrário. 2.ed. Rio de Janeiro: Renovar, 1997.

LINHARES, M. Y.; SILVA, F. C. T. da. Terra prometida: uma história da questão agrária no Brasil. Rio de Janeiro: Campus, 1999.

LINS, A. P. de C. Direito à alimentação. Disponível em: <http://dhnet.org.bt/ dados $/$ cursos $/ \mathrm{dh} / \mathrm{br} / \mathrm{pb} / \mathrm{dhparaiba} / 5 /$ alimentaçãohtml>. Acesso em: 15 maio 2007.

LIVORSI, F. Il mito della nuova terra. Milano: Giuffré, 2000.

LOPES, J. R. L. Crise da norma jurídica e a reforma do judiciário. In: FARIA, J. E. (Org.) Direitos humanos, direitos sociais e justiça. São Paulo: Malheiros, 2002. p.68-93.

LUCAS, J. de. El concepto de solidaridad. México: Fontanara, 1998.

LUIS, E.; MARQUES, H. Pesquisa traça perfil de integrantes do MST. O Estado de S. Paulo, São Paulo, 14 maio 2000. p.A26.

LUÑO, A. H. P. Derechos humanos, estado de derecho y constituición. 8.ed. Madrid: Tecnos, 2003.

La tercera generación de derechos humanos. Navarra: Aranzadi, 2006.

LUZ, V. P. da. Curso de direito agrário. Porto Alegre: Sagra Luzzatto, 1993.

MADEIRA, W. Unidades de conservação e assentamentos rurais: visões interdisciplinares. In: . (Org.) Direito e justiça ambiental. Niterói: UFF, Programa de Pós-Graduação, 2002.

MADELEY, J. O comércio da fome. Petrópolis: Vozes, 2003. 
MAGALHÃES, R. Integração, exclusão e solidariedade no debate contemporâneo sobre políticas sociais. Cadernos de Saúde Pública (Rio de Janeiro), n.17, maio/jun. 2001.

MALUF, R. S. J. Produtos agroalimentares, agricultura multifuncional e desenvolvimento territorial no Brasil. In: COSTA, L. F.; MOREIRA, R. (Org.) Mundo rural e cultura. Rio de Janeiro: Mauad, 2002. p.241-60.

Segurança alimentar e nutricional. Petrópolis: Vozes, 2007.

MANIGLIA, E. Terra, justiça e democracia. Revista de Estudos Jurídicos da UNESP (Franca), ano 2, n.4, p.253-60, jul./dez. 1997.

Da possibilidade do turismo rural ser integrado como atividade agrária. Revista de Estudos Jurídicos da Unesp (Franca), ano 4, n.8, p.219-228, jul./dez. 1999.

O trabalho rural sob a ótica do direito agrário: uma opção ao desemprego no Brasil. Franca: Unesp, 2002.

Atendimento da função social pelo imóvel rural. In: BARROSO, L. de A. et al. (Org.) O direito agrário na Constituição. Rio de Janeiro: Forense, 2005. p.25-44.

Criminalidade e violência no âmbito rural: críticas e reflexões. In: BARROSO, L. de A. et al. (Org.) A lei agrária nova. Curitiba: Juruá, 2006. p.179-92.

MANIR, M. Cinco pães e dois peixes. O Estado de S. Paulo, São Paulo, 3 dez. 2006. Aliás, p.J5.

MARCIAL, A. B. Estúdios de derecho agrario y política agraria. Madrid: Tipo Linea, 1975.

La función social del suelo rustico y de la propriedad privada: estúdios en homenaje a Vallet de Goytisolo. Madrid: Junta de Decanos de los Colégios Notariales de España, 1991. t.5.

MARES, C. F. A função social da terra. Porto Alegre: Sérgio Fabris, 2003.

MARTINS, J. de S. O poder do atraso. São Paulo: Hucitec, 1999.

Reforma agrária: o impossível diálogo. São Paulo: Edusp, 2000.

O futuro da sociologia rural e sua contribuição para a qualidade de vida rural. Estudos Avançados (São Paulo), v.15, n.43, p.31-6, set./dez. 2001.

MARTINS, M. L. R. Construindo a cidadania: o papel da cidade. In: GALEAZZI, M. A. M. Segurança alimentar e cidadania: a contribuição das universidades paulistas. Campinas: Mercados das Letras, 1996. p.109-16.

MARTINS, S. P.; MOREIRA, C. B. S. Programa de aquisição de alimentos da agricultura familiar. In: Centro de estudos multidisciplinares; núcleo de estudos agrários. Fome zero: políticas públicas e cidadania. Brasília: Editora da UnB, ago. 2004. p.125-35. (Cadernos, ano 6, n. 14).

MARX, K. O capital: crítica da economia política. Trad. Regis Barbosa e Flávio Kothe. São Paulo: Abril Cultural, 1984. v.1, t.2.

MATTOS NETO, A. J. de. A posse agrária e suas implicações jurídicas no Brasil. Belém: Cejup, 1988. 
MAUREL, M. C. A exploração familiar na França. In: LAMARCHE, H. A agricultura familiar. 2.ed. Campinas: Editora da Unicamp, 1997. p.97-173.

MELLO, C. A. B. de. Novos aspectos da função social da propriedade no direito público. Revista de Direito Público (São Paulo), n.84, p.39-45, 1984.

MELO, M. de F. Água: o direito de proteger. Revista Proposta (Água: Território e Conflitos) (Rio de Janeiro), ano 29, n.106, p.6-9, set./nov. 2005.

MENDES, J. J. A. O homem face ao meio ambiente. In: (Org.) Problemas ecológicos do mundo agrário. Coimbra: Almedina, 1977. p.161-88.

MENDES, V. Sem aldeia, sem saúde, sem saída: retratos do Brasil. O Estado de S. Paulo, São Paulo, 22 jan. 2006. Nacional, p.A6.

MIGUEL, J. F. D. de. Estúdios de derecho agrario. Madrid: Montecorvo, 1993. Derecho agrario de la Unión Europea. Madrid: Thebook, 1996. Derecho agrario de la Unión Europea. 2.ed. Madrid: Thebook, 1998.

MIGUEL NETO, S. Questão agrária. Campinas: Bookseller, 1997.

MINISTÉRIO DO DESENVOLVIMENTO AGRÁRIO. Lei de agricultura familiar recebe sanção presidencial. Disponível em: <http://www.mda.gov.br/ index.php? sccid=134\&ctuid=9827>. Acesso em: 2 jul. 2007.

MIRANDA, A. G. de. Teoria do direito agrário. Belém: Cejup, 1989.

Segurança alimentar na Amazônia: a produção agroindustrial típica na Amazônia e a segurança do alimento. Revista de Direito Agrário, Ambiental e da Alimentação - Publicação oficial da Academia de Letras Agrárias - (Rio de Janeiro), ano 1, n.1, p.299-308, jul. 2004/jun. 2005.

MIRANDA, J. Manual de direito constitucional: direitos fundamentais. Coimbra: Coimbra, 1988. t.4.

MONREAL, E. N. El derecho de propriedad privada. Bogotá: Temis, 1979.

MONTEIRO, C. Hambre, pobreza y desnutrición en Brasil: precisando conceptos. In: CENTRO DE ESTUDOS MULTIDISCIPLINARES; NÚCLEO DE ESTUDOS AGRÁRIOS. Derecho a la alimentación en el Brasil de Lula. Brasília: Editora da UnB, 2004. p.185-91.

MONTIBELLER FILHO, G. O mito do desenvolvimento sustentável. 2.ed. Florianópolis: UFSC, 2004.

MORAES, A. de. Direitos humanos fundamentais. 6.ed. São Paulo: Atlas, 2005.

MORAES FILHO, E. Introdução ao direito do trabalho. São Paulo: LTr, 1969.

MORAIS, J. L. B. de. As crises do estado e da constituiçãa e a transformação espacial dos direitos humanos. Porto Alegre: Livraria do Advogado, 2002.

MOREIRA, A. C. Terra não é renda é capital. Revista Panorama Rural (São Paulo), ano 6, n.66, p.10, jul. 2004.

MYRDAL, G. Teoria econômica e regiões subdesenvolvidas. Trad. N. Palhardo. 3.ed. Rio de Janeiro: Saga, 1972.

NAVARRO, Z. Desenvolvimento rural no Brasil: os limites do passado e os caminhos do futuro. Estudos Avançados (São Paulo), v.15, n.43, p.83-100, set./ dez. 2001. 
NEVES, A. C. Ensaio de uma reposição crítica: a crise. Lisboa: Almedina, 1967. v.1.

NEVES, D. P. Agricultura familiar: questão metodológica. Revista de Reforma Agrária (Campinas), v.25, n.2-3, p.21-36, maio/dez. 1995.

Assentamento rural: reforma agrária em migalhas. Niterói: UFF, 1997.

NICOLINI, G. Diritto agrário. 3.ed. Padova: Cedam, 1980.

NOBRE JUNIOR, E. P. Desapropriação para fins de reforma agrária. Curitiba: Juruá, 2000.

OLIVEIRA, F. M. de; GUIMARÃES, F. R. Direito, meio ambiente e cidadania: uma abordagem disciplinar. São Paulo: Madras, 2004.

OLIVEIRA, M.; RACINE, E. Bolsa alimentação. In: CENTRO DE ESTUDOS MULTIDISCIPLINARES; NÚCLEO DE ESTUDOS AGRÁRIOS. Derecho a la alimentación en el Brasil de Lula. Brasília: Editora da UnB, 2004. p.137-49.

OLIVEIRA, U. M. de. Princípios de direito agrário na Constituição vigente. Curitiba: Juruá, 2004.

PAINE, T. Los derechos del hombre. Trad. J. Fernandez de Castro e Munhoz Molina. México: FCE, 1944.

PARANÁ. SECRETARIA DE ESTADO DO TRABALHO, EMPREGO E PROMOÇÃO SOCIAL. Segurança alimentar nos anos 90. Disponível em: $<$ http://www.sine.pr.gov.br/setp/conselhos/consea/index.php?id=10>. Acesso em: 16 out. 2006.

PASOLD, C. L. Função social do Estado contemporâneo. 3.ed. Florianópolis: OAB, Diploma Legal, 2003.

PEREIRA, J. M. M. Neoliberalismo, políticas de terra e reforma agrária de mercado na América Latina. In: PEREIRA, J. M. M.; SAUER, S. (Org.) Capturando a terra. São Paulo: Expressão Popular, 2006. p.13-48.

PEREIRA, R. P. C. Rodrigues. A teoria da função social da propriedade rural e seus reflexos na acepção clássica de propriedade. Revista de Direito Civil (São Paulo), n.65, p.104-128, jul./set. 1993.

PESSANHA, L. D. R.; JOHN, W. Transgênicos, recursos genéticos e segurança alimentar: o que está em jogo nos debates? Campinas: Armazém do Ipê, 2005.

PESSOTTO, C. Bem ambiental. Florianópolis: Anuário Ecológico, 2005.

PIOVEZAN, F. Direitos humanos e o direito constitucional internacional. 7.ed. São Paulo: Saraiva, 2006.

Proteção dos direitos econômicos, sociais e culturais e do direito à alimentação adequada: mecanismos nacionais e internacionais. In: PIOVEZAN, F.; CONTI, I. L. (Org.) Direito humano à alimentação adequada. Rio de Janeiro: Lumen Júris, 2007. p.17-48.

PONTES DE MIRANDA, F. C. Tratado de direito privado. 4.ed. São Paulo: Revista dos Tribunais, 1983. t.1.

PRADO JÚNIOR, C. A questão agrária no Brasil. São Paulo: Brasiliense, 1979. 
PROENÇA, R.; POULAI, J. P. Sociologia da alimentação: um enfoque na compreensão dos comportamentos alimentares. In: TADDEI, J. A. (Coord.) Jornadas científicas do Nisan. Barueri: Minha Editora, 2007. p.165-78.

PY, P. Droit du tourisme. 5.ed. Paris: Dalloz, 2002.

RAMALHO, J. R.; MARTINS, H. de S. Tercerização: diversidade e negociação no mundo do trabalho. São Paulo: Hucitec, 1994.

RAMOS, A. de C. Processo internacional de direitos humanos. Rio de Janeiro: Renovar, 2002.

REIS, F. Escravos da miséria e do descaso. Jornal do Magistrado (Brasília), ano 15, n.73, p. 8-12, mar./abr. 2004.

REZEK, G. E. K. Imóvel agrário: agrariedade, ruralidade e rusticidade. Curitiba: Juruá, 2007.

RIECHMANN, J. Cultivos e alimentos transgênicos: um guia crítico. Petrópolis: Vozes, 2002.

RIOS, R. R. Princípio democrático e reforma agrária. In: SILVEIRA, D. S. D.; XAVIER, F. S. (Org.) O direito agrário em debate. Porto Alegre: Livraria do Advogado, 1998. p.195-211.

ROCHA, O. A. L. A desapropriação no direito agrário. São Paulo: Atlas, 1992. Atividade Agrária: conceito clássico, conceito moderno de Antonio Carrozza. Revista da Faculdade de Direito da USP (São Paulo), v.94, p.35-43, 1999.

RODRIGUES, M. H. Os direitos sociais na Constituição. In: PIOVEZAN, F.; CONTI, I. L. (Org.) Direito humano à alimentação adequada. Rio de Janeiro: Lumen Júris, 2007. p.113-22.

RODRIGUES, M.; ARANTES, O. Direito ambiental e biotecnologia: uma abordagem sobre os transgênicos sociais. Curitiba: Juruá, 2004.

ROIG, M. J. A. Necesidades y derechos: um ensayo de fundamentación. Madrid: Centro de Estúdios Constitucionales, 1994.

ROMANO, J.; DELGADO, N. Os planos municipais de desenvolvimento rural como processos sociais. In: COSTA, L. F.; MOREIRA, R. (Org.) Mundo rural e cultura. Rio de Janeiro: Mauad, 2002. p.285-302.

ROMEIRO, A. R. Reforma agrária e distribuição de renda. In: STÉDILE, J. P. (Org.) A questão agrária hoje. 2.ed. Porto Alegre: Editora da Universidade Federal, 1994. p.105-36.

ROSA, J. G. Grandes sertões: veredas. Rio de Janeiro: Nova Fronteira, 2006.

ROSSET, P. Alternativa à política fundiária de mercado, reforma agrária e soberania alimentar. In: PEREIRA, J. M. M.; SAUER, S. Capturando a terra. São Paulo: Expressão Popular, 2006. p.315-42.

SACHS, I. Caminhos para o desenvolvimento sustentável. Org. Paula Ione Stroh. Rio de Janeiro: Garamond, 2002.

Desenvolvimento includente, sustentável e sustentado. Rio de Janeiro: Garamond, 2004.

SAKAMOTO, L. A economia da escravidão. Disponível em: <http://www.reporterbrasil.com.br>. Acesso em: 15 maio 2006. Material enviado pela Renap 
[mensagem pessoal]. Mensagem recebida por <ema@francanet.com.br> em 15 de maio de 2006.

SANT'ANNA, L. Crianças ainda sustentam famílias com ou sem o dinheiro do governo. Retratos do Brasil: a intenção e a realidade. O Estado de S. Paulo, São Paulo, 2 abr. 2006a. Nacional, p.A27.

Proibição do trabalho infantil revolta comunidade em Minas. O Estado de S. Paulo, São Paulo, 2 abr. 2006b. Nacional, p.A28.

SANTOS, B. S. Elite é socialmente democrática, mas socialmente fascista. Disponível em: <http://sfainfo.rits.org.br/show.txt.php?key=202>. Acesso em: 30 jul. 2004.

SANTOS, D. J. Desarrollo sustentable y biotecnologia. México: Universidade de Guaquil, 2000.

SANTOS, J. C. dos. As raízes do crime. Rio de Janeiro: Forense, 1984.

SANTOS, M. J. dos. Projeto alternativo de direito sustentável. In: UNIVERSIDADE DE SÃO PAULO. Dossiê desenvolvimento rural. São Paulo: Edusp, 2000. p.225-238. (Estudos Avançados, v.43).

SANTOS JÚNIOR, B. Retrato da terra: perfil sócio-econômico dos assentamentos do estado de São Paulo. Revista do Itesp (São Paulo), n.2, p.2-6, jul. 1998.

SANTOS NETTO, A. P. dos. A atividade agrária e o conteúdo do direito agrário. Revista de Direito Agrário (Brasília), ano 11, n.11, p.51-55, jul./dez. 1986.

SANZ JARQUE, J. J. Derecho agrario: general, autonómico y comunitário. Madrid: Reus, 1985. v.1.

SARLET, I. W. A eficácia dos direitos fundamentais. 2.ed. Porto Alegre: Livraria do Advogado, 2001.

SATER, E. Poder econômico na mídia. In: PAPA, F. et al. (Org.) Manual de mídia e direitos humanos. São Paulo: Consórcio Universitário pelos Direitos Humanos, 2001.

SCAFF, F. C. Aspectos fundamentais da empresa agrária. São Paulo: Malheiros, 1997.

SCARDOELLI, D. Y. A atividade rural brasileira face ao princípio constitucional tributário da capacidade contributiva. Franca, 2004. Dissertação (Mestrado em Direito) - Faculdade de História, Direito e Serviço Social, Universidade Estadual Paulista.

SCOTTO, G. et al. Desenvolvimento sustentável. Petrópolis: Vozes, 2007.

SEBRAE. O bom exemplo da aldeia. Globo Rural (São Paulo), ano 21, n.247, p. 8991, fev. 2006a.

Como o agricultor pode vender para o governo. Globo Rural (São Paulo), ano 21, n.251, p.88-90, ago. 2006b.

SICHIERI, R.; NASCIMENTO, S. do. O custo da obesidade para o sistema único de saúde. Perspectivas para as próximas décadas. In: TADDEI, J. A. (Coord.) Jornadas científicas do Nisan. Barueri: Minha Editora, 2007. p.101-11.

SILVA, C. E. M. Democracia e sustentabilidade na agricultura: subsídios para a construção de um novo modelo de desenvolvimento rural. Rio de Janeiro: Fase, 2001. (Cadernos Temáticos, n.4). 
SILVA, G. O sonho da casa no campo. Globo Rural (São Paulo), ano 16, n.185, p.62-6, mar. 2001.

SILVA, J. A. da. Curso de direito constitucional positivo. 27.ed. São Paulo: Malheiros, 2006.

SILVA, J. G. da. A reforma agrária na virada do milênio. Campinas: Abra, 1996.

SILVA, J. G. da. O novo rural brasileiro. In: SHIKI et al. (Org.) Agricultura, meio ambiente e sustentabilidade do cerrado brasileiro. Uberlândia: Universidade $\mathrm{Fe}$ deral, Embrapa, Unicamp, 1977. p.75-100.

O que é questão agrária? 16.ed. São Paulo: Brasiliense, 1990.

Por uma reforma agrária não essencialmente agrícola. Revista Agroanalysis

(Rio de Janeiro), n.16, p.8-11, mar. 1996.

. Tecnologia e agricultura familiar. Porto Alegre: UFRGS, 1999.

Por que separar o urbano do rural? Globo Rural (São Paulo), ano 17, n.197, p.64-5, mar. 2002.

SILVA, R. Reforma agrária e desenvolvimento. Disponível em: <http://agenciacartamaior.uol.com.br/agencia.asp>. Acesso em: 22 abr. 2004.

SOARES, J. E. Brasil: um país de contrastes. In: SYNGENTA PROTEÇÃO DE CULTIVOS LTDA. (Org.) A terra na terra: um livro sobre a agricultura e o trabalho com o solo. São Paulo: Books, 2005. p.110-22.

SOARES, R. A. de A. Proteção ambiental e desenvolvimento econômico. Curitiba: Juruá, 2004.

SOCIEDADE NACIONAL DA AGRICULTURA. Da monocultura ao agrobusiness: a história da Sociedade Nacional de Agricultura. Brasília: Sociedade Nacional de Agricultura, 2005.

SODERO, F. Direito agrário e reforma agrária. São Paulo: Legislação Brasileira, 1968.

SOTO, W. H. G. A produção do conhecimento sobre o mundo rural no Brasil: as contribuições de José de Souza Martins e José Graziano da Silva. Santa Cruz do Sul: Edunisc, 2002.

SOUZA, C. Estado do campo: da pesquisa em políticas públicas no Brasil. Revista Brasileira de Ciências Sociais (São Paulo), v.18, n.51, p.27-41, 2003.

SOUZA, J. Efeitos ópticos da nossa miséria. O Estado de S. Paulo, São Paulo, 12 nov. 2006. Aliás, p.J5.

SPOSATI, A. Segurança alimentar e desafio às universidades. In: GALEAZZI,

M. A. M. Segurança alimentar e cidadania: a contribuição das universidades paulistas. Campinas: Mercados das Letras, 1996. p.190-3.

SUPLICY, E. M. Renda de cidadania: a resposta dada pelo vento. Porto Alegre: L\&PM, 2006.

TAMBARÁ, E. RS: modernização e crise na agricultura. Porto Alegre: Mercado Aberto, 1985.

TEÓFILO, E. A necessidade de uma reforma agrária ampla e participativa para o Brasil. Brasília: Nead, 2002. 
TOMAZELA, J. M. Fazenda Pirituba é exemplo de produtividade. O Estado de S. Paulo, São Paulo, 29 abr. 2001. p.A13.

O medo e a morte rondam os canaviais. O Estado de S. Paulo, São Paulo, 27 nov. 2005a. p.B14.

. É uma escravidão sutil constata a Pastoral. O Estado de S. Paulo, São Paulo, 27 nov. 2005b. p.B15.

TRINDADE, A. A. C. Direitos humanos e meio ambiente. Porto Alegre: Sérgio Fabris, 1993.

UNIÃO EUROPEIA. Ajuda humanitária. Execução da ajuda humanitária. Atividades da União Europeia. Disponível em: <http://eu/sendplus/leg/pt/ lvbr10001.htm>. Acesso em: 22 jan. 2007a.

Panorama das atividades da União Europeia. Agricultura. Disponível em: $<$ http://europa.eu/pol/env/overview-pt.htm>. Acesso em: 22 jan. 2007b.

VALENTE, F. L. S. Direito humano à alimentação: desafios e conquistas. São Paulo: Cortez, 2002a.

Instrumentos internacionais de proteção e promoção do direito humano à alimentação e nutrição. In: . (Org.) Direito humano à alimentação: desafios e conquistas. São Paulo: Cortez, 2002b. p.187-206.

VALENTE, F. L. S. et al. Instrumentos e mecanismos não judiciais de exigibilidade do direito humano à alimentação adequada no Brasil. In: PIOVEZAN, F.; CONTI, I. L. (Org.) Direito humano à alimentação adequada. Rio de janeiro: Lumen Júris, 2007. p.149-74.

VAQUÉ, L. G. La libre circulación de los productos alimentícios en la Unión Europea: tres opciones para assegurar la protección de la salude de los consumidores. Revista Española de Derecho Europeo (Madrid), p.394-414, jul./sep. 2004.

VARELLA, M. D. MST: um novo movimento social? In: SILVEIRA, D. S. D.; XAVIER, F. S. (Org.) O direito agrário em debate. Porto Alegre: Livraria do Advogado, 1998. p.212-38.

VEIGA, J. E. da. O Brasil ainda não encontrou seu eixo de desenvolvimento. Estudos Avançados (São Paulo), v.15, n.43, p.101-20, set./dez. 2001.

A história não os absolverá nem a geografia. Campinas: Armazém do Ipê, 2005.

Desenvolvimento sustentável: o desafio do século XXI. 2.ed. Rio de Janeiro: Garamond, 2006a.

Meio ambiente e desenvolvimento. São Paulo: Senac, 2006b.

VIAL, S. R. M. Propriedade da terra: análise sócio-jurídica. Porto Alegre: Livraria do Advogado, 2003.

VIVANCO, A. C. Teoria del derecho agrario. La Plata: Libreria Jurídica, 1967.

WALD, A. Direito das coisas. 6.ed. São Paulo: RT, 1991.

WANDERLEY, M. N. A agricultura familiar no Brasil: um espaço em construção. Revista de Reforma Agrária (Campinas), v.25, n.2-3, p.37-57, maio/dez. 1995. 
A modernização da agricultura: projeto político e escolhas da sociedade. In: GALEAZZI, M. A. M. Segurança alimentar e cidadania: a contribuição das universidades paulistas. Campinas: Mercados das Letras, 1996. p.263-71.

A valorização da agricultura familiar e a reivindicação da ruralidade no Brasil. In: UFRP. Desenvolvimento e meio ambiente: a reconstrução da ruralidade e a relação sociedade/natureza. Curitiba: UFPR, 2000. p.29-38.

WEIS, C. Os direitos humanos contemporâneos. São Paulo: Malheiros, 1999.

WOLKMER, A. C. Pluralismo jurídico. 3.ed. São Paulo: Alfa Ômega, 2001.

Humanismo e cultura jurídica no Brasil. Florianópolis: Fundação Boiteaux, 2003.

Direitos humanos e filosofia jurídica na América Latina. Rio de Janeiro: Lumen Júris, 2004.

O direito como humanismo social e possibilidade de emancipação. In: . (Org.) Fundamentos do humanismo jurídico no Ocidente. Barueri: Manole; Florianópolis: Fundação Boiteaux, 2005. p.129-44.

ZAMBERLAM, J.; FRONCHETI, A. Agricultura ecológica. Petrópolis: Vozes, 2002.

ZELEDON Y ZELEDON, R. Derecho agrario y derechos humanos. Curitiba: Juruá, 2002.

ZIBETTI, D. Cidadania e segurança alimentar no Brasil. In: BARROSO, L.; PASSOS, C. Direito agrário contemporâneo. Belo Horizonte: Del Rey, 2004. p.135-48.

ZIEGLER, J. Report of the special rapporteur of the Commission on Human the Right to Food. Disponível em: <http://www.righttofood.org>. Acesso em: 24 abr. 2007.

ZIMERMMANN, A. Planejamento e organização do turismo rural no Brasil. In: ALMEIDA, J. A. et al. (Org.) Turismo rural e desenvolvimento sustentável. 4.ed. Campinas: Papirus, 2000. p.127-42.

ZIMMERMANN, C. As políticas públicas e a exigibilidade do direito humano à alimentação. In: PIOVEZAN, F.; CONTI, I. L. (Org.) Direito humano à alimentação adequada. Rio de Janeiro: Lumen Júris, 2007a. p.123-40.

Implementação do direito humano à alimentação adequada: do Bolsa Família à renda básica de cidadania. In: ROSA, E.; CONTI, I. L. Direito humano à alimentação adequada no Brasil. Passo Fundo: Ifibe, 2007b. p.29-51. 
SOBRE O LIVRO

Formato: $16 \times 23 \mathrm{~cm}$

Mancha: $27,5 \times 49,0$ paicas

Tipologia: Horley Old Style 11/15

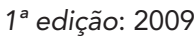

EQUIPE DE REALIZAÇÃO

Coordenação Geral Marcos Keith Takahashi 


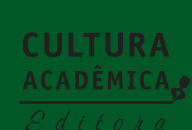

